OECD Economics Department Working Papers No. 811

\title{
Trade Linkages \\ in the OECD Trade System
}

\section{Jérôme Brezillon,}

Stéphanie Guichard,

Dave Turner 
Organisation de Coopération et de Développement Économiques

Organisation for Economic Co-operation and Development

27-Oct-2010

ECONOMICS DEPARTMENT

English text only

TRADE LINKAGES IN THE OECD TRADE SYSTEM

ECONOMICS DEPARTMENT WORKING PAPER No.811

by

Jérôme Brézillon, Stéphanie Guichard and Dave Turner

All Economics Department Working Papers are available through OECD's internet website at www.oecd.org/eco/workingpapers

JT03291242

Document complet disponible sur OLIS dans son format d'origine

Complete document available on OLIS in its original format 


\section{ABSTRACT/RÉSUMÉ}

\section{Trade Linkages in the OECD Trade System}

This paper describes the sources and methods used to construct the trade matrices of the OECD trade system. It also provides an overview of the trade relationships between countries, especially individual OECD countries and the main non-OECD economies, as well as their evolution between 2000 and 2005. It finally serves more broadly as a "ready reckoner" guide to the sensitivity to shocks that are transmitted through trade.

JEL classification codes: F10; F40

Keywords: Trade; trade matrices; bilateral trade flows

*************************************

\section{Les relations commerciales dans le système de commerce de l'OCDE}

Ce document décrit les sources et méthodes utilisées pour la construction des matrices de commerce $\mathrm{du}$ système de commerce international de l'OCDE. Il donne une vue d'ensemble des relations commerciales entre pays, et notamment entre les pays membres de l'OCDE et les principales économies non-OCDE, ainsi que leur évolution entre 2000 et 2005. Ce document sert aussi plus généralement comme guide "prêt-à-l'emploi" de la sensibilité aux chocs transmis par le commerce.

Classification JEL : F10 ; F40

Mots-clés : Echanges commerciaux ; matrices des échanges ; commerce bilatéral

\section{Copyright OECD 2010}

Applications for permission to reproduce or transfer all, or part of, this material should be made to: Head of Publications Service, OECD, 2 rue André Pascal, 75775 Paris Cedex 16, France 


\section{TABLE OF CONTENTS}

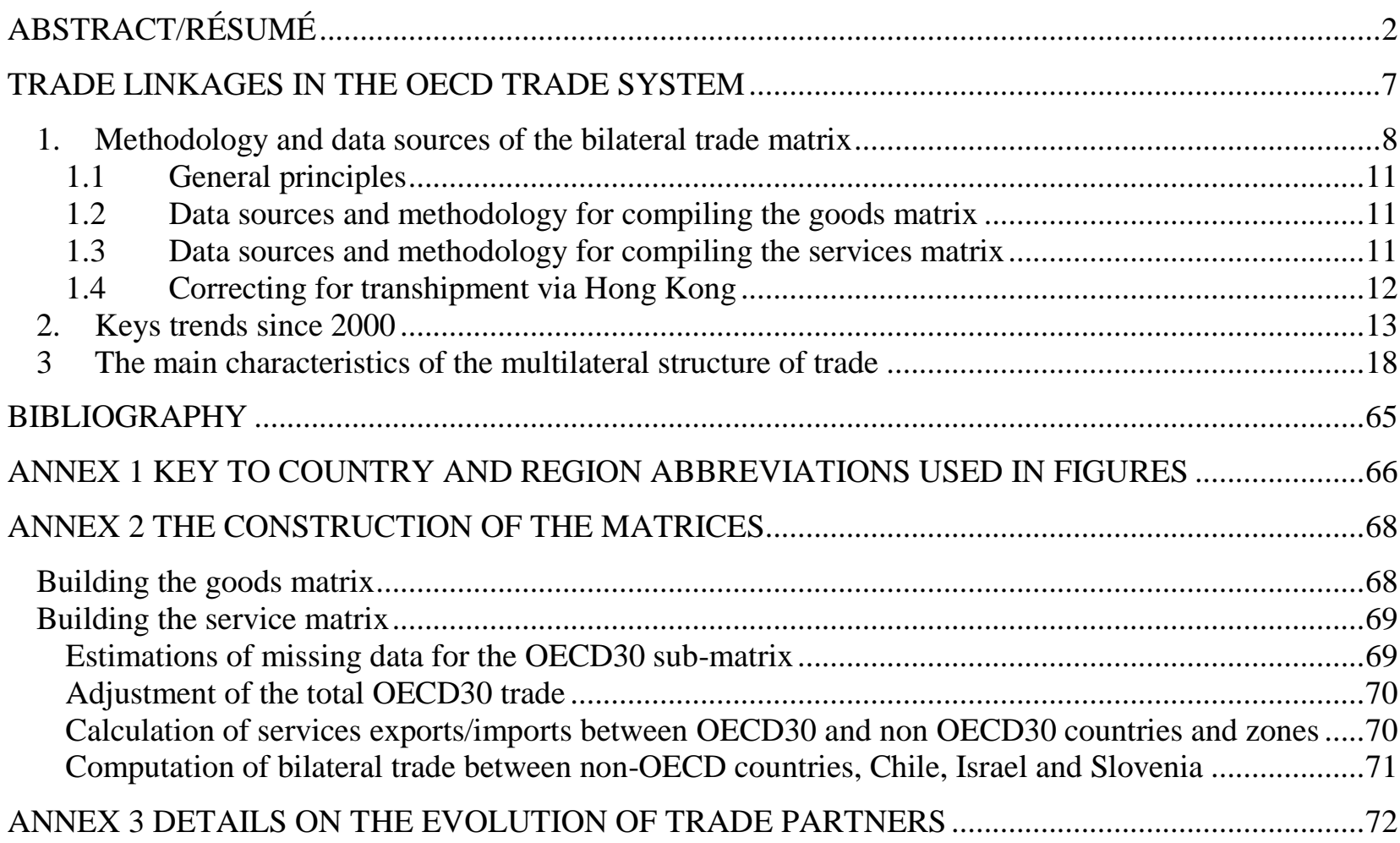

\section{Boxes}

Box 1. Trade indicators based on the trade matrix .8

\section{Tables}

1. The share of OECD and non-OECD countries in world trade of goods and services ..................13

2. The share of the main zones in world trade of goods and services .........................................14

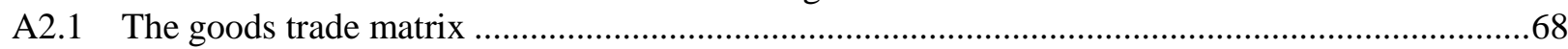

Figures

1. Evolution of the share of individual countries in world trade .............................................15

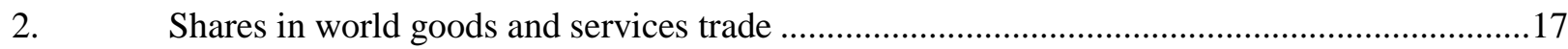

3.1 Geographical structure of goods and services trade of the United States ..............................19

3.2 Geographical structure of goods and services trade of Japan .............................................20

3.3 Geographical structure of goods and services trade of the euro area ......................................21 
3.4 Geographical structure of goods and services trade of Germany..........................................22

3.5

Geographical structure of goods and services trade of France..................................................23

3.6

Geographical structure of goods and services trade of Italy ...................................................24

3.7

Geographical structure of goods and services trade of the United Kingdom...........................25

3.8

3.9

Geographical structure of goods and services trade of Canada .................................................26

3.10

3.11

3.12

3.13 .

Geographical structure of goods and services trade of Australia..............................................27

Geographical structure of goods and services trade of Austria.................................................28

Geographical structure of goods and services trade of Belgium..............................................29

Geographical structure of goods and services trade of Chile...................................................30

Geographical structure of goods and services trade of the Czech Republic ...............................31

3.14

Geographical structure of goods and services trade of Denmark................................................32

3.15

Geographical structure of goods and services trade of Finland ..................................................33

3.16

Geographical structure of goods and services trade of Greece ...................................................34

3.17

Geographical structure of goods and services trade of Hungary ............................................35

3.18 Geographical structure of goods and services trade of Iceland................................................36

3.19 Geographical structure of goods and services trade of Ireland ...............................................37

3.20 Geographical structure of goods and services trade of Korea................................................38

3.21 Geographical structure of goods and services trade of Luxembourg .......................................39

3.22 Geographical structure of goods and services trade of Mexico ...............................................40

3.23 Geographical structure of goods and services trade of the Netherlands .................................41

3.24 Geographical structure of goods and services trade of New Zealand ......................................42

3.25 Geographical structure of goods and services trade of Norway..............................................43

3.26 Geographical structure of goods and services trade of Poland ................................................44

3.27 Geographical structure of goods and services trade of Portugal ............................................45

3.28 Geographical structure of goods and services trade of the Slovak Republic ...........................46

3.29 Geographical structure of goods and services trade of Slovenia ............................................47

3.30 Geographical structure of goods and services trade of Spain ...............................................48

3.31 Geographical structure of goods and services trade of Sweden ..............................................49

3.32 Geographical structure of goods and services trade of Switzerland .......................................50

$3.33 \quad$ Geographical structure of goods and services trade of Turkey …........................................51

3.34 Geographical structure of goods and services trade of Argentina .........................................52

3.35 Geographical structure of goods and services trade of Brazil.................................................53

$3.36 \quad$ Geographical structure of goods and services trade of China ................................................54

3.37 Geographical structure of goods and services trade of Estonia .............................................55

$3.38 \quad$ Geographical structure of goods and services trade of India ..................................................56

3.39 Geographical structure of goods and services trade of Indonesia ...........................................57

3.40 Geographical structure of goods and services trade of Israel ..............................................58

3.41 Geographical structure of goods and services trade of the Russian Federation .......................59

3.42 Geographical structure of goods and services trade of Saudi Arabia ....................................60

3.43 Geographical structure of goods and services trade of South Africa ......................................61

3.44 Geographical structure of goods and services trade of Dynamic Asia Economies...................62

3.45 Geographical structure of goods and services trade of oil producers .....................................63

3.46 Geographical structure of goods and services trade of remaining countries...........................64

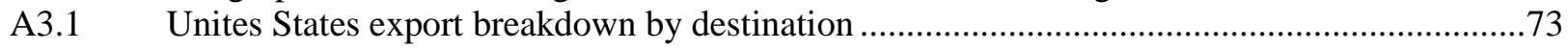

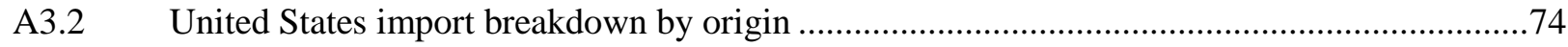

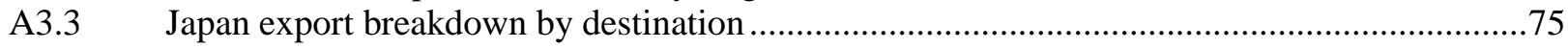

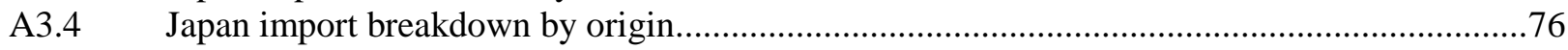

A3.5 Canada export breakdown by destination .............................................................................

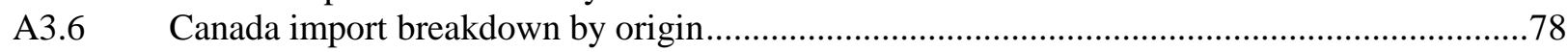

A3.7 Germany export breakdown by destination .........................................................................

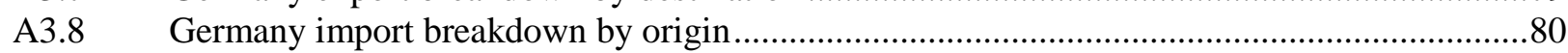




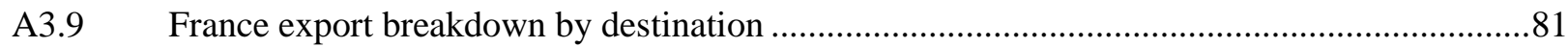

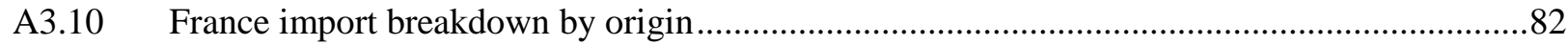

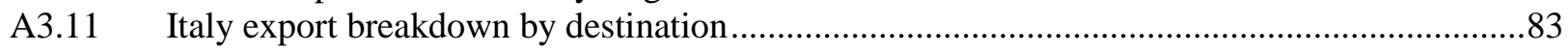

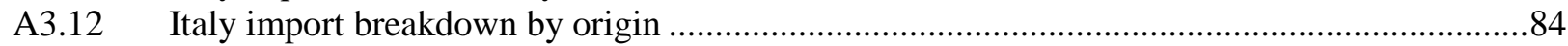

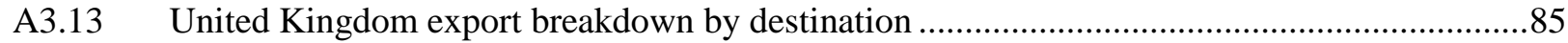

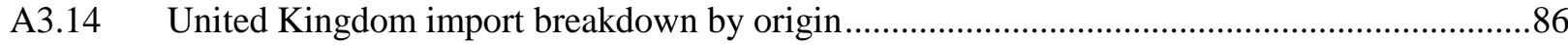

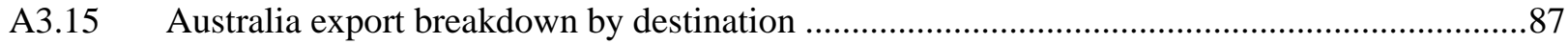

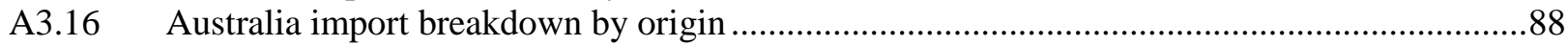

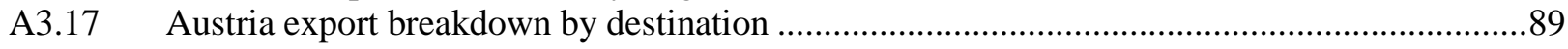

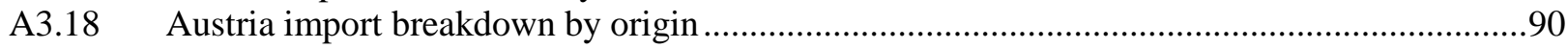

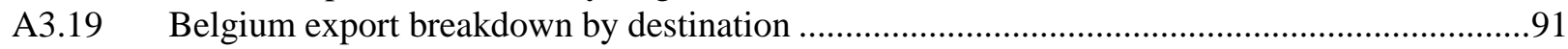

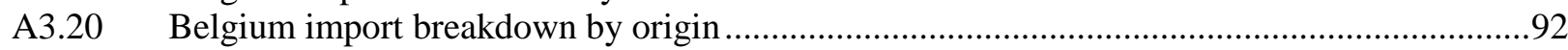

A3.21 Czech Republic export breakdown by destination............................................................93

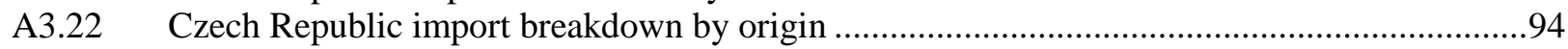

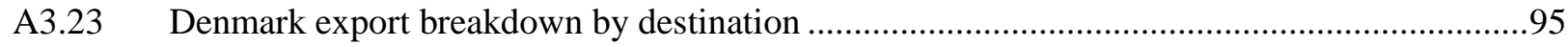

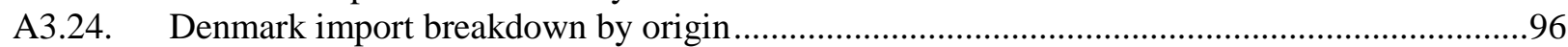

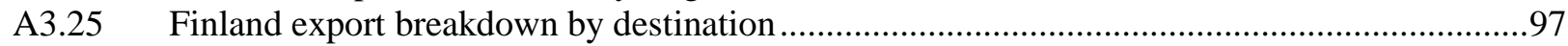

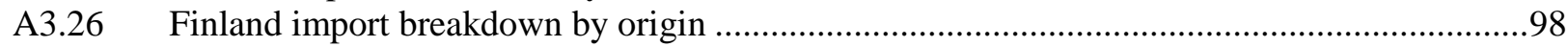

A3.27 Greece export breakdown by destination ..............................................................................99

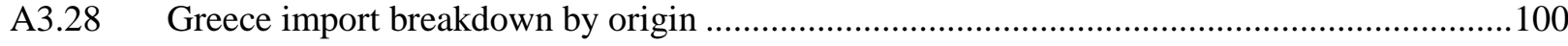

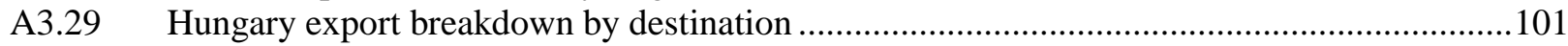

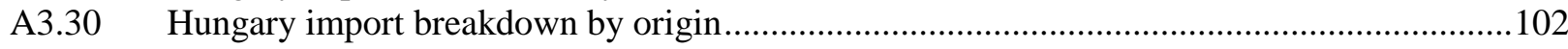

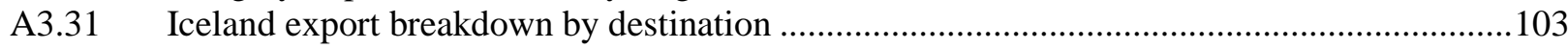

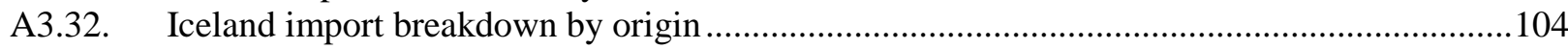

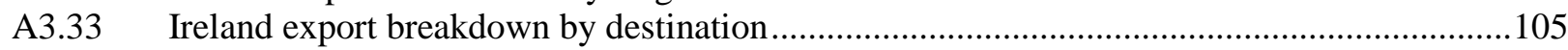

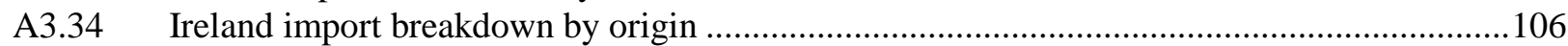

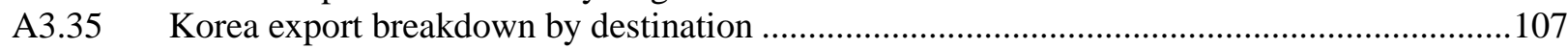

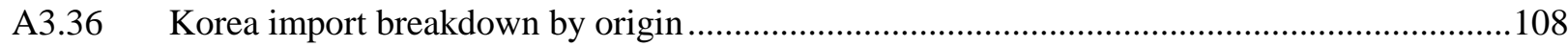

A3.37 Luxembourg export breakdown by destination ……............................................................ 109

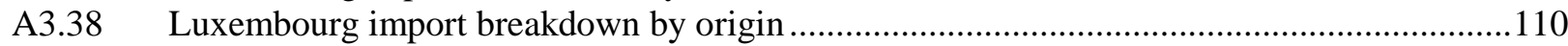

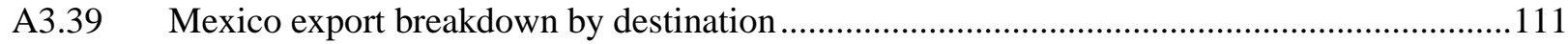

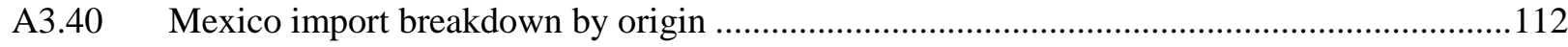

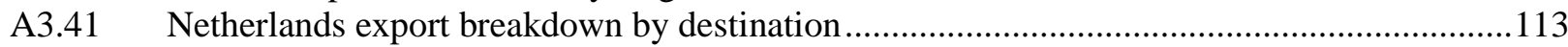

A3.42 Netherlands import breakdown by origin .........................................................................

A3.43 New Zealand export breakdown by destination..................................................................115

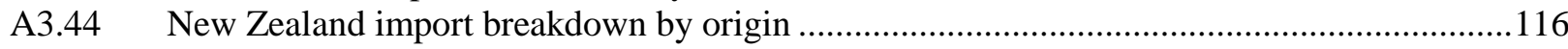

A3.45 Norway export breakdown by destination .......................................................................117

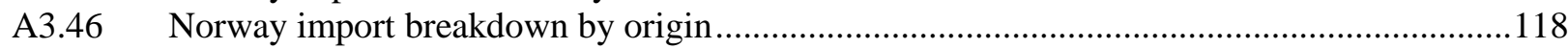

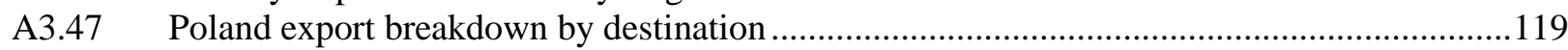

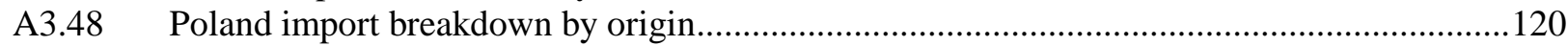

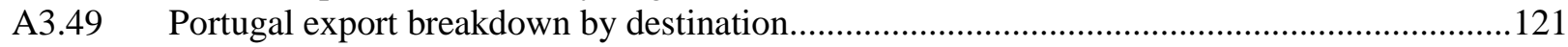

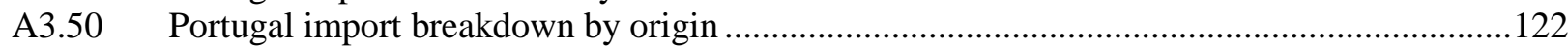

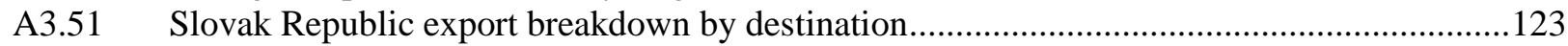

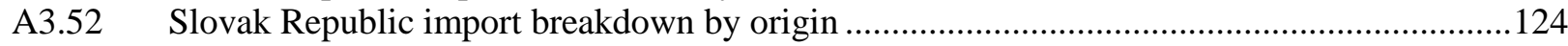

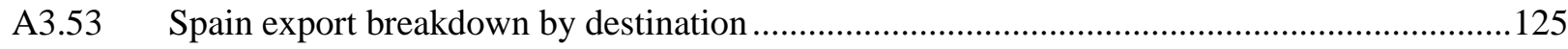

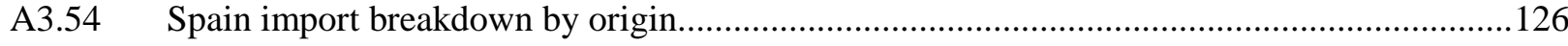

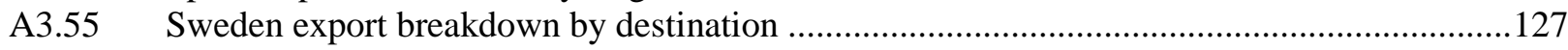

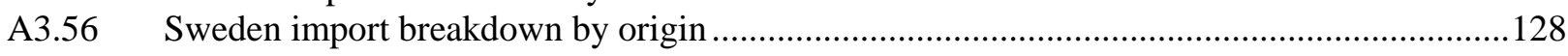

A3.57 Switzerland export breakdown by destination .................................................................129

A3.58 Switzerland import breakdown by origin...........................................................................

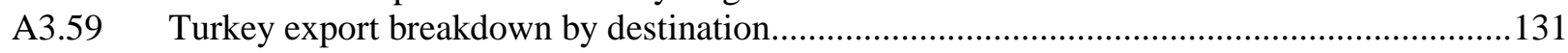




\section{ECO/WKP(2010)67}

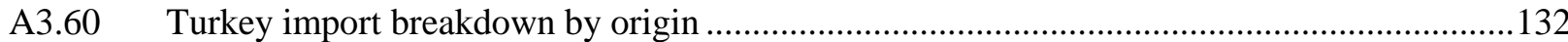

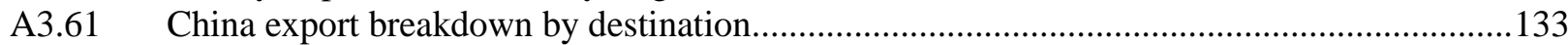

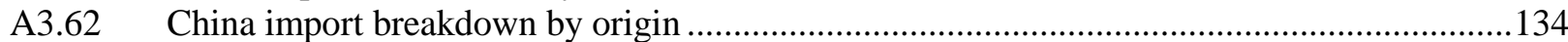


ECO/WKP(2010)67

\title{
TRADE LINKAGES IN THE OECD TRADE SYSTEM
}

\author{
by
}

Jérôme Brézillon, Stéphanie Guichard and Dave Turner ${ }^{1}$

1. Trade linkages and trade global consistency are essential components of the projections published in the OECD Economic Outlook. The OECD system of trade linkages relies on a matrix of bilateral flows of goods and services between OECD countries and several non-OECD countries and zones. ${ }^{2}$ The construction of such a matrix is not an easy task given limited data availability on bilateral trade flows for some countries and the need to combine different sources while keeping the matrix consistent with national trade data.

2. This paper first details the methodology and sources used to build the most recent trade matrix for 2005. It then compares the current trade matrix to the previous 2000 version in order to assess the evolution of global trade flows over this period. ${ }^{3}$ As expected, it shows that the share of non-OECD countries, essentially Dynamic Asian economies and China, in world trade has increased, mostly at the expense of North America, and to a lesser extent of OECD Asian countries. OECD Europe as a whole has managed to maintain its market share. The paper also provides a very detailed review of each country's main trading partners. Annex 1 presents the geographical breakdown and country and zone abbreviations. Annex 2 presents some technical details on the construction of the 2005 trade matrix and Annex 3 presents some country details on the change in the geographical trade structure between 2000 and 2005.

1. The authors are members of Country Studies IV and the Macroeconomic Analysis Division of the OECD Economics Department. They would like to thank Richard Herd and Christian Gianella for helpful comments and discussions and Diane Scott for assistance in preparing the document. The views expressed in this paper are those of the authors and do not necessarily represent those of the OECD or its member countries.

2. The OECD trade system uses a fixed matrix which is updated by five years every five years. The advantage of a fixed matrix for competitiveness indicators is that it enables the assessment of the impact of changes in prices which can be isolated from changes in weights due to the change in countries' relative market share. One disadvantage is that for historical years far away from the base year the weights derived from the matrix do not reflect the prevailing structure of trade.

3. The 2000 matrix is described in Le Fouler et al. (2001). 


\section{Methodology and data sources of the bilateral trade matrix}

3. The OECD trade system is based on a 45 by 45 matrix of bilateral trade flows of goods and services covering the 33 OECD countries as well as nine non-OECD economies and three non-OECD economics areas. ${ }^{4}$ The matrix is used to build several indicators including those for export markets for goods and services and competitiveness (see Pain et al., 2005 and Box 1). These indicators in turn play an important role in analysing recent trade developments, in informing trade projections and in enforcing global trade consistency.

\section{Box 1. Trade indicators based on the trade matrix}

Export market for goods and services, volume, US\$, 2000 prices (XMKT)

$$
X M K T_{i}=\left(\sum_{p=1}^{N} \frac{X G S_{i \rightarrow p}}{X G S_{\text {wld } \rightarrow p}} * M G S V D_{p}\right)
$$

where: $X G S_{i \rightarrow p}=$ goods and services export values in 2005 from country $\mathrm{i}$ to country $\mathrm{p}$

$$
\text { MGSVD }_{p}=\text { import volume of country } p, \text { expressed in } 2005 \text { US } \$
$$

Competitor's prices of goods and services exports (PXC)

$$
\operatorname{PXC}_{i}=\left(\sum_{\substack{p=1 \\ p \neq i}}^{N} \frac{X G S_{i \rightarrow p}}{X G S_{\text {wld } \rightarrow p}-X G S_{i \rightarrow p}} * \frac{1}{X G S_{i \rightarrow \text { wld }}} * \sum_{\substack{r=1 \\ r \neq i, p}}^{N} X G S_{r \rightarrow p} * \text { PXGS }_{r} * \text { EXCHIN }_{r}\right) * \frac{1}{\text { EXCHIN }_{i}}
$$

Where, $P X G S_{p}=$ Exports of goods and services, deflator, national accounts basis of country $\mathrm{p}$

$$
\text { EXCHIN }_{i}=\text { Exchange rate, index of USD per local currency unit of country } \mathrm{i}
$$

4. The geographical breakdown has evolved over time to follow the accession of new countries to the OECD and the extension of the coverage of the non-members. In particular, the system has recently increased from 30 OECD countries, China and five non-member zones to 33 OECD countries (following the accession of Chile, Slovenia and Israel in 2010) as well as nine non-OECD economies and three nonOECD economics areas (see Annex 1). For the sake of comparison with the 2000 system the updated 2005 system still includes an OECD30 zone including only the countries that were part of the OECD in 2000. Since Israel joined in September 2010 after most of the calculations in this paper were completed it is not included in some of the OECD aggregates. 


\section{Shadow price of non-commodity goods and services imports (PMSHX)}

$$
\text { PMSHX }_{i}=\left(\sum_{p=1}^{N} \frac{X G S_{p \rightarrow i}}{X G S_{\text {wld } \rightarrow i}} * \operatorname{PXGSX}_{p} * \operatorname{EXCHIN}_{p}\right) * \frac{1}{\text { EXCHIN }_{i}}
$$

where $\operatorname{PXGSX}_{p}=$ Price of non-commodity exports of goods and services of country $\mathrm{p}$

\section{Calculation of intra trade times series for the zones}

Calculation of the share of extra and intra trade for each country

Since the trade goods and services matrix gives the share of imports and exports for a country with all countries in the world, the share of trade with a specific zone, and the share of trade with the rest of the world excluding this zone can be calculated. These shares are then applied to each export and import series (values and volumes in 2005 prices) of each country's total trade to obtain series for extra and intra trade for a given zone.

Aggregation of goods and services series for intra and extra trade

Using a chainlink method, with fixed weights in 2005 it is possible to obtained the extra trade imports and exports for a zone, the intra trade of imports and exports for a zone and the total trade of imports and exports for a zone defined as the sum of intra and extra trade.

For instance for exports of intra trade exports of zone $\mathrm{i} X \mathrm{i}$ is derived from a weighted average of the exports of the $p$ countries belonging to the zone. The weights are the share of the zone in the exports of the country in 2005.

$$
\frac{X_{i}[t]}{X_{i}[t-1]}=\sum_{\substack{p=1,1 \\ p \subset i}}^{N}\left(\frac{X_{p}[t]}{X_{p}[t-1]} * \frac{\sum_{\substack{k=1, k \subset i}}^{N} X_{p->k}[2005]}{X_{p}[2005]}\right)
$$

Unfortunately, using this method, there is no consistency between intra trade exports and intra trade imports. Exports intra $_{i}[t] \neq$ Imports in tra ${ }_{i}[t]$

This can be corrected using the formula:

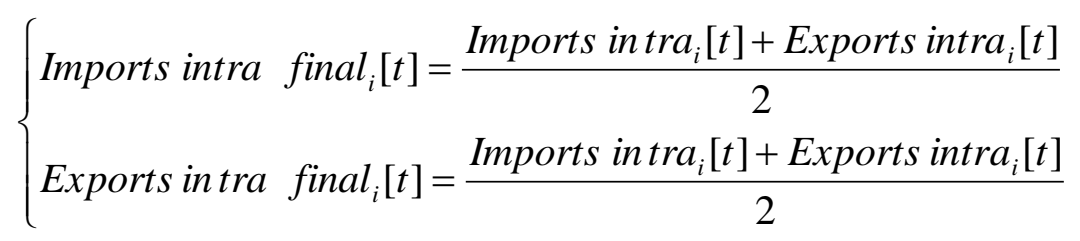

And extra trade can then be calculated as the difference between total trade and these adjusted intra trade series.

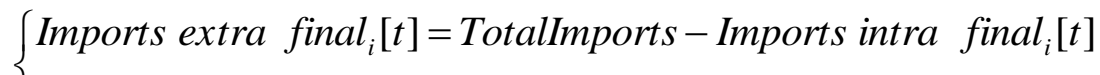

$$
\begin{aligned}
& \text { Exports extra } \text { final }_{i}[t]=\text { Total Exports }- \text { Exports intra final }{ }_{i}[t]
\end{aligned}
$$

The evolution of intra and extra trade of the OECD and the euro area is shown on the figure below. The first part of the 2000 s is characterised by a growing deficit of the two zones with the rest of the world. In both case also, during the crisis exports to the rest of the world contracted before imports and intra trade. 


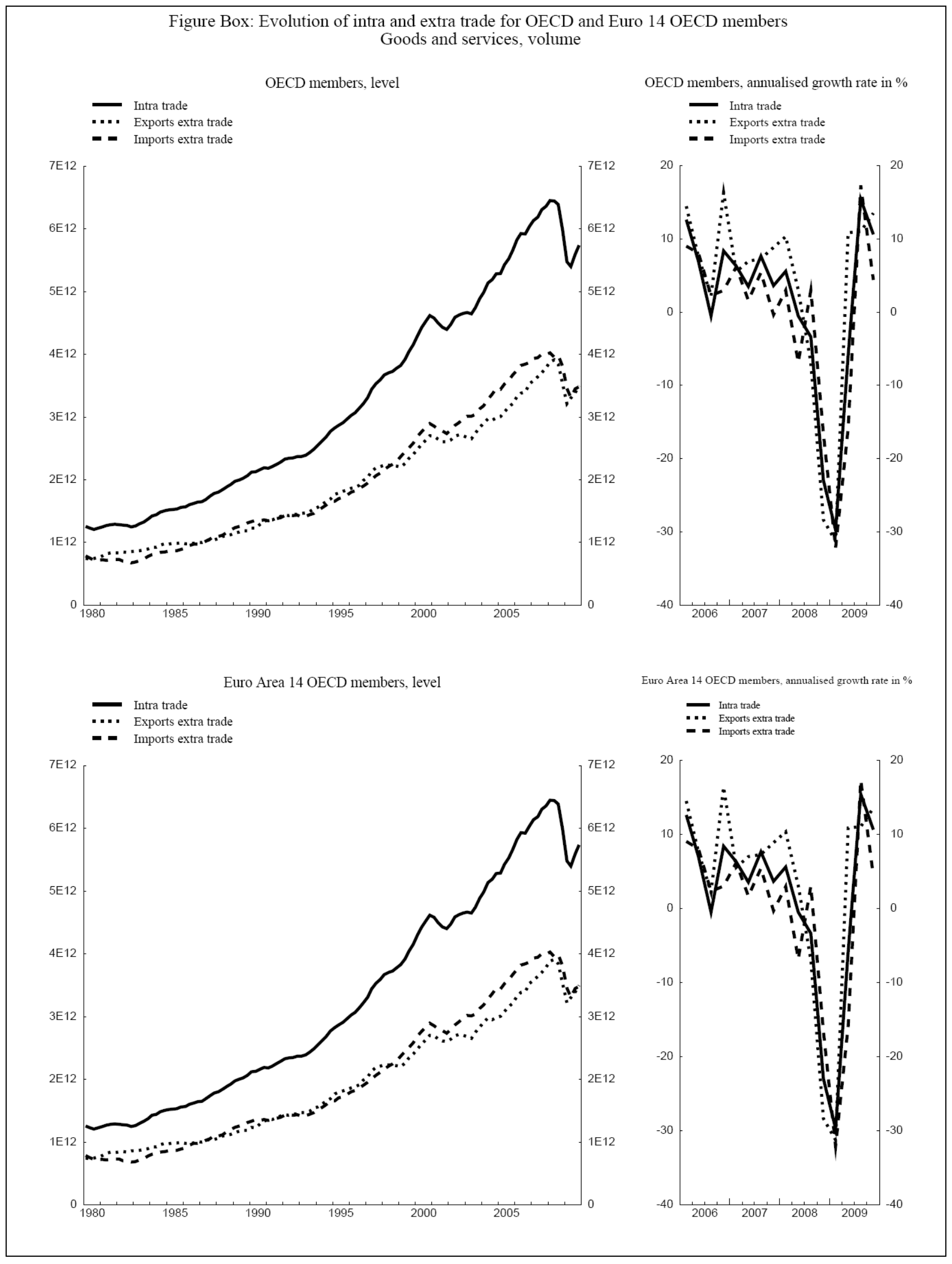




\subsection{General principles}

4. The coverage of trade in both goods and services implies the construction of two distinct matrices, one for bilateral merchandise trade and one for bilateral trade in services which are then aggregated. Merchandise trade still accounts for $81 \%$ of global trade and largely shapes the goods and services matrix and its evolution over time. While the quality of the data is relatively satisfactory for goods, statistics for exports or imports of services are not systematically available on the required bilateral basis even for OECD countries. Consequently, a number of assumptions have to be made to complete missing services data, using both the information given by the aggregate level of trade in goods or services and the share of bilateral trade of merchandise in total merchandise trade.

5. As a rule, the matrices are completed with export series for two reasons: first, export series are usually of much better quality and, second, import data are rarely available on a consistent free on board basis (f.o.b.). When export data are missing, the matrices are completed with mirror series whenever possible. A systematic procedure of cross-checking has been implemented, by comparing export/import series with mirror data from corresponding trading partners. For OECD bilateral merchandise trade, no substantial differences were found between export and their mirror series.

\subsection{Data sources and methodology for compiling the goods matrix}

6. There are two main international sources of bilateral merchandise trade: the data from the IMF's Direction of Trade Statistics (DOTS database, merchandise trade flows for more than 180 countries, customs-based) and the COMTRADE database from United Nation (also customs-based). While the two sets give comparable results for OECD countries, the quality of the data for non-OECD countries is better in the DOTS trade statistics and when aggregated at the country level, exports and imports from the DOTS are closer to national trade flows. The DOTS is therefore the main source used for the bilateral matrix of goods trade flows. ${ }^{5}$

7. Adjustments to the bilateral matrix to ensure that total exports and imports match national data are detailed in Annex 2.1.

\subsection{Data sources and methodology for compiling the services matrix}

8. For bilateral trade in services, the OECD Statistics on International Trade in Services is the only available source. Although many bilateral trade flows are missing and have to be estimated, the coverage has substantially improved in comparison with the data used for the 2000 matrix. $^{6}$

9. A sub-matrix for OECD30 can be filled using the OECD Statistics on International Trade in Services. For the missing values of bilateral trade between OECD30 countries, cells can be completed using the relative share of merchandise trade as the corresponding weight (see Annex 2.2 for more details). For a few countries it appears that the sum of bilateral trade flows of services is well out of line with the

5. COMTRADE data are however used to take into account the role of Hong Kong as a shipping port (see below). Also data for Luxembourg and Chinese Taipei are taken from other sources.

6. Twelve OECD countries now have a complete breakdown of trade series (Austria, Denmark, France, Hungary, Ireland, Italy, Luxembourg, Netherlands, Poland, Portugal, Sweden and the United Kingdom) and seven others an almost complete breakdown (Australia, Belgium, Canada, Czech Republic, Finland, Japan and Norway). 
total exports or imports obtained from MEI or national sources. ${ }^{7}$ In these cases, further adjustments have to be made to obtain a row/column of the matrix coherent with aggregate series (see Annex 2.2). In addition, the same database is used to complete China's trade flows with OECD30, as a relatively complete set of mirror series for China is available. Missing values are completed as described in Annex 2.2.

10. For the other non-OECD countries and for Chile, Israel and Slovenia, it is not possible to use mirror series given the paucity of data and all bilateral trade flows countries and zones have to be estimated. The weights of merchandise trade have been applied to the matrix of services. Then adjustment to ensure that for each country the sum of reported value is equal total services trade by country is exactly the same as that presented for the goods matrix presented in Annex 2.1.

\subsection{Correcting for transhipment via Hong Kong ${ }^{8}$}

11. The role of Hong Kong as a shipping port for China and other Asian countries is a source of potential bias. Domestic exports (excluding re-exports) account for less than 5\% of Hong Kong's total exports and domestic imports (i.e. not meant to be re-exported ) account for about a quarter of Hong Kong's total imports. The re-export trade by Hong Kong has three components: shipment of goods to China from partner countries, shipment of Chinese goods to partner countries, and shipment of goods from countries other than China to countries other than China. Trade flows associated with the role of Hong Kong as a shipping port result therefore in an over-estimation of bilateral trade flows between the Dynamic Asia region (in which Hong Kong is included) and the other countries or zones and an under-estimation of bilateral flows between partner countries, and notably between China and other countries. In the absence of a correction, effective exchange rates derived from the trade matrix would also be biased, with the weight of China over-estimated in the effective exchange rate of Hong-Kong and under-estimated for all other countries, while the weight of Hong Kong would be over-estimated in the RMB effective exchange rate and the exchange rate of all other countries.

12. Re-export data are available in COMTRADE by destinations and there is some information provided by the Hong Kong authorities on the re-export by origins. The shipment of goods from countries other than China to countries other than China is very limited and was ignored, so that it is assumed that all re-exports of Hong Kong to countries other than China originated in China. The matrix has therefore been corrected and exports from China to Dynamic Asia and exports from Dynamic Asia to other countries than China have been reduced, and replaced by equivalent direct flows from China to other countries than China. Exports from countries other than China to Dynamic Asia and from Dynamic Asia to China were reduced and replaced by a flow from these countries to China. An $8 \%$ export margin for re-exports from China to the rest of the world and a 32\% export margin for re-exports from the rest of the world to China are assumed based on Wang et al. (2007). These changes to the matrix result in a lowering of the weight of Dynamic Asia as a trade partner of all countries. In the case of China, after the adjustment it represents only $12 \%$ of exports and $26 \%$ of imports (compared to $23 \%$ and $37 \%$ before the adjustment respectively).

7. This concerns Mexico, the Netherlands, Switzerland and Turkey. The sum of bilateral trade in services for the United Kingdom also exceeds the aggregate number found in the balance of payments by a large amount, particularly on the import side. This discrepancy might reflect a different treatment of financial services.

8. This correction is not done for other countries with important shipping and re-export activity either because at the world level this activity remains negligible or because the data on bilateral re-exports necessary to do the correction is not available. 


\section{Keys trends since 2000}

13. The evolution of the trade matrix between the 2000 and the 2005 matrices reflects recent trends in globalisation. First, the non-OECD share in world trade has increased markedly, from about one-quarter to close to one-third (Table 1). This corresponds to both an increase of trade within non-OECD zones and, to a lesser extent, a rise in trade between OECD and non-OECD countries. The counterpart has mainly been a decrease in NAFTA's share in world trade (Table 2). The loss of NAFTA's market share is observed on both the export and import side. The weight of the OECD Asia Pacific zone in world trade has also shrunk, but less markedly than the weight of NAFTA, while the weight of European countries has slightly increased. The increase in the weight of Europe was driven not only by goods by also by a strong increase in the share in world exports of services.

Table 1. The share of OECD and non-OECD countries in world trade of goods and services (2005)

\begin{tabular}{|c|cc|c|}
\hline Exporters & OECD & Non-OECD & World \\
\hline \multirow{2}{*}{ OECD } & $52.9 \%$ & $15.8 \%$ & $68.6 \%$ \\
& $(-4.8 \%)$ & $(1.7 \%)$ & $(-3.3 \%)$ \\
\multirow{2}{*}{ Non-OECD } & $19.1 \%$ & $12.3 \%$ & $31.4 \%$ \\
& $(1.9 \%)$ & $(1.4 \%)$ & $(3.3 \%)$ \\
& & & \\
\hline \multirow{2}{*}{ World } & $72.0 \%$ & $28.0 \%$ & $100.0 \%$ \\
& $(-2.9 \%)$ & $(2.9 \%)$ & \\
\hline
\end{tabular}

Note: Changes since 2000 in Italics.

14. At the individual country level, the most important changes have been the rise in the share of China, which has jumped from the eighth rank in world exporters and ninth rank in world importers to the third in both between 2000 and 2005, at the expense mainly of the United States and Japan (Figure 1). Interestingly, the increase in the share of German exports in world exports has not been a matched by corresponding increase in the share of German imports in world imports. More details on the evolution of the breakdown of each country's imports and exports by partner are provided in Annex 3; they show notably the increase in share of Eastern European countries in the trade of Germany, France and Italy at the expense of trade between these three countries. 
Table 2. The share of the main zones in world trade of goods and services (2005)

GOODS and SER VICES Matrix

\begin{tabular}{|c|c|c|c|c|c|c|c|c|c|c|c|c|}
\hline \multirow[b]{2}{*}{ Exporters } & \multicolumn{2}{|c|}{$\begin{array}{l}\text { OECD30 } \\
\text { Europe }\end{array}$} & \multicolumn{2}{|c|}{ NAFTA } & \multicolumn{2}{|c|}{$\begin{array}{c}\text { OECD30 } \\
\text { Pacific Asia }\end{array}$} & \multicolumn{2}{|c|}{ China } & \multicolumn{2}{|c|}{$\begin{array}{l}\text { Other non- } \\
\text { OECD } 30^{1}\end{array}$} & \multicolumn{2}{|c|}{ World } \\
\hline & 2000 & 2005 & 2000 & 2005 & 2000 & 2005 & 2000 & 2005 & 2000 & 2005 & 2000 & 2005 \\
\hline OECD30 EUROPE & 29.4 & 29.9 & 5.2 & 4.7 & 1.5 & 1.4 & 0.5 & 0.8 & 5.5 & 6.9 & 42.0 & 43.7 \\
\hline NAFTA & 4.3 & 3.2 & 9.7 & 7.4 & 2.2 & 1.5 & 0.4 & 0.6 & 3.7 & 2.8 & 20.3 & 15.5 \\
\hline OECD30 Pacific Asia & 1.8 & 1.5 & 3.2 & 2.1 & 1.4 & 1.3 & 1.0 & 1.7 & 3.6 & 3.0 & 11.0 & 9.5 \\
\hline China & 0.9 & 1.5 & 1.2 & 2.5 & 1.0 & 1.3 & 0.0 & 0.0 & 0.6 & 2.1 & 3.7 & 7.4 \\
\hline Other non-OECD $30^{1}$ & 6.1 & 6.6 & 5.0 & 4.1 & 3.4 & 3.1 & 1.4 & 2.3 & 7.2 & 7.8 & 23.0 & 24.0 \\
\hline WORLD & 42.5 & 42.7 & 24.2 & 20.7 & 9.5 & 8.6 & 3.2 & 5.3 & \begin{tabular}{|l|}
20.5 \\
\end{tabular} & 22.7 & 100.0 & 100.0 \\
\hline
\end{tabular}

\section{GOODS Matrix}

\begin{tabular}{|c|c|c|c|c|c|c|c|c|c|c|c|c|}
\hline \multirow[b]{2}{*}{ Exporters } & \multicolumn{2}{|c|}{$\begin{array}{l}\text { OECD30 } \\
\text { Europe }\end{array}$} & \multicolumn{2}{|c|}{ NAFTA } & \multicolumn{2}{|c|}{$\begin{array}{c}\text { OECD30 } \\
\text { Pacific Asia }\end{array}$} & \multicolumn{2}{|c|}{ China } & \multicolumn{2}{|c|}{$\begin{array}{l}\text { Other non- } \\
{\text { OECD } 30^{1}}^{1}\end{array}$} & \multicolumn{2}{|c|}{ World } \\
\hline & 2000 & 2005 & 2000 & 2005 & 2000 & 2005 & 2000 & 2005 & 2000 & 2005 & 2000 & 2005 \\
\hline OECD30 EUROPE & 29.3 & 29.7 & 4.4 & 3.9 & 1.3 & 1.2 & 0.5 & 0.8 & 5.4 & 6.2 & 41.0 & 41.8 \\
\hline NAFTA & 3.3 & 2.3 & 11.0 & 8.2 & 1.9 & 1.1 & 0.4 & 0.6 & 3.1 & 2.4 & 19.7 & 14.6 \\
\hline OECD30 Pacific Asia & 2.0 & 1.5 & 3.4 & 2.1 & 1.5 & 1.3 & 1.2 & 1.9 & 3.8 & 3.0 & 11.8 & 9.9 \\
\hline China & 1.0 & 1.7 & 1.5 & 3.0 & 1.1 & 1.5 & 0.0 & 0.0 & 0.4 & 2.2 & 4.0 & 8.4 \\
\hline${\text { Other non-OECD } 30^{1}}^{1}$ & 6.1 & 6.7 & 5.1 & 4.5 & 3.4 & 3.2 & 1.4 & 2.5 & 7.5 & 8.3 & 23.6 & 25.2 \\
\hline WORLD & 41.7 & 42.0 & 25.4 & 21.8 & 9.2 & 8.3 & 3.5 & 5.8 & 20.2 & 22.1 & 100.0 & 100.0 \\
\hline
\end{tabular}

\section{SERVICES Matrix}

\begin{tabular}{|c|c|c|c|c|c|c|c|c|c|c|c|c|}
\hline \multirow[b]{2}{*}{ Exporters } & \multicolumn{2}{|c|}{$\begin{array}{l}\text { OECD30 } \\
\text { Europe }\end{array}$} & \multicolumn{2}{|c|}{ NAFTA } & \multicolumn{2}{|c|}{$\begin{array}{c}\text { OECD30 } \\
\text { Pacific Asia }\end{array}$} & \multicolumn{2}{|c|}{ China } & \multicolumn{2}{|c|}{$\begin{array}{l}\text { Other non- } \\
\text { OECD } 30^{1}\end{array}$} & \multicolumn{2}{|c|}{ World } \\
\hline & 2000 & 2005 & 2000 & 2005 & 2000 & 2005 & 2000 & 2005 & 2000 & 2005 & 2000 & 2005 \\
\hline OECD30 EUROPE & 29.7 & 30.6 & 8.2 & 7.9 & 2.1 & 2.3 & 0.2 & 0.6 & 6.0 & 9.8 & 46.2 & 51.2 \\
\hline NAFTA & 8.4 & 6.8 & 4.7 & 4.1 & 3.6 & 2.9 & 0.3 & 0.4 & 5.8 & 4.6 & 22.8 & 18.8 \\
\hline OECD30 Pacific Asia & 1.4 & 1.3 & 2.3 & 1.9 & 1.2 & 1.0 & 0.3 & 0.6 & 2.7 & 3.0 & 7.9 & 7.8 \\
\hline China & 0.3 & 0.5 & 0.2 & 0.3 & 0.5 & 0.6 & 0.0 & 0.0 & 1.2 & 1.7 & 2.2 & 3.1 \\
\hline Other non-OECD $30^{1}$ & 5.7 & 6.2 & 4.2 & 2.3 & 3.4 & 2.7 & 1.4 & 1.8 & 6.3 & 6.1 & 21.0 & 19.1 \\
\hline WORLD & 45.5 & 45.3 & 19.6 & 16.5 & 10.7 & 9.5 & 2.3 & 3.4 & 22.0 & 25.3 & 100.0 & 100.0 \\
\hline
\end{tabular}

1. Includes Chile, Israel, and Slovenia.

Source: OECD calculation. 
Figure 1. Evolution of the share of individual countries in world trade

In percentage
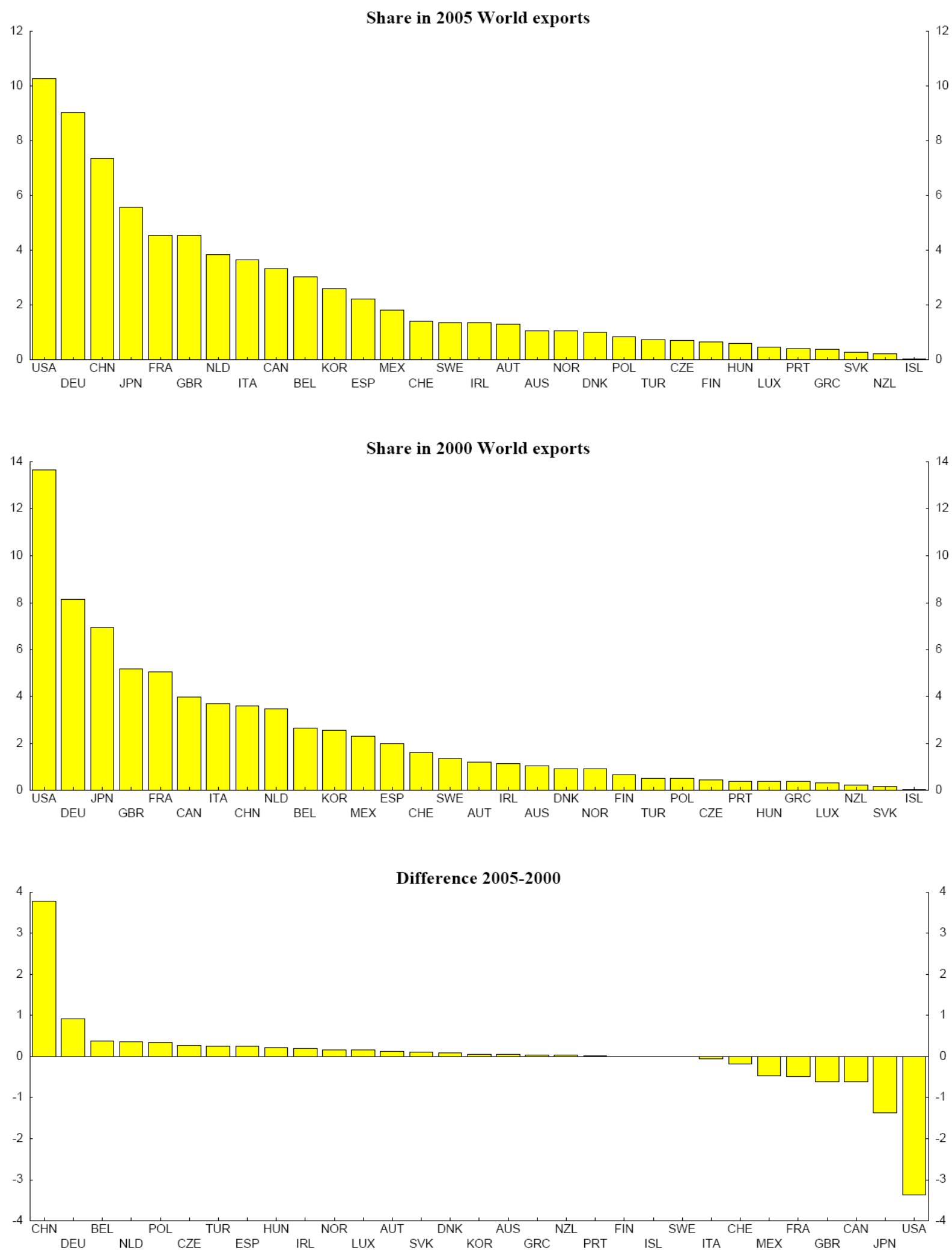
Figure 1. Evolution of the share of individual countries in world trade (cont'd)
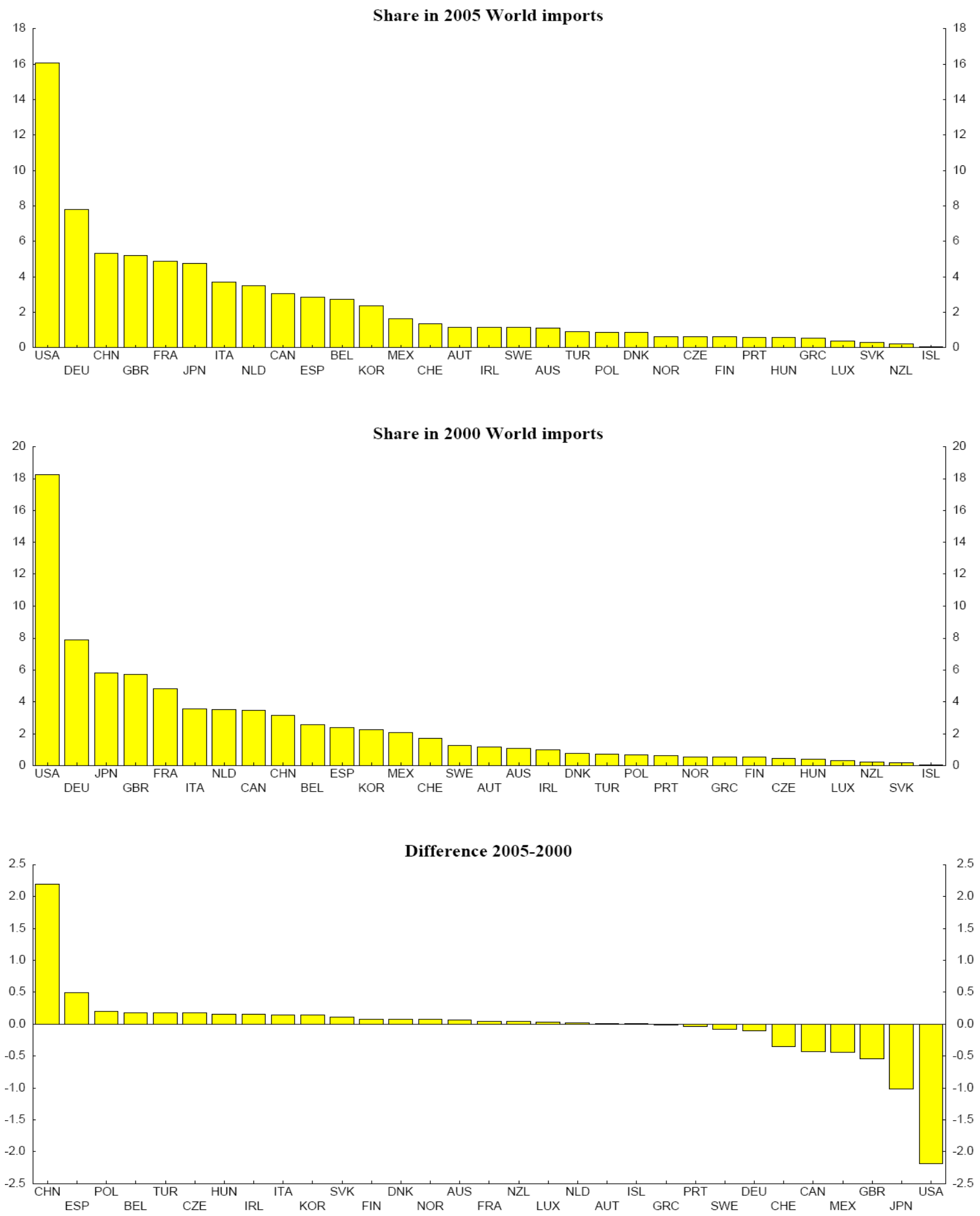

Source: OECD calculations. 
15. Most of the trade of the OECD countries remains within the OECD, with about three-quarters of the OECD imports from the OECD and a bit more of exports going to OECD partners (Figure 1). Intra OECD trade accounts for a bit more than half of world trade. A third of world trade flows are between the OECD countries and non-OECD countries, with Asia (China and dynamic Asian Economies) the main economic partner area of the OECD and accounting for 13.6\% of the OECD total imports (close to half the OECD imports from non-OECD countries) and 10.9\% of its exports (again close half the OECD exports outside the OECD). Trade flows between non-OECD countries account for less than $15 \%$ of world trade flows.

Figure 2. Shares in world goods and services trade

Main world regions trade as per cent of world trade

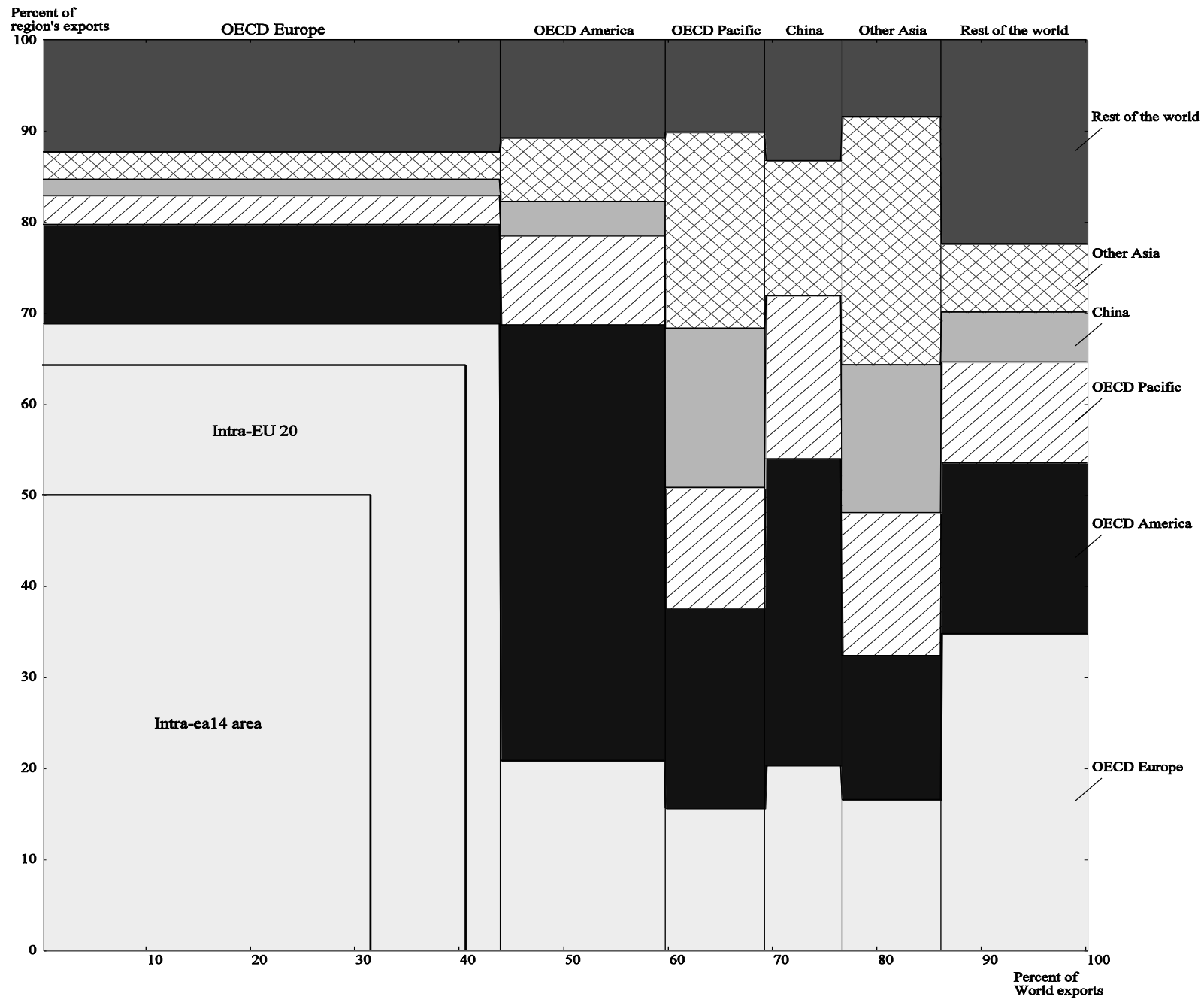

Source: OECD calculations. 
3

The main characteristics of the multilateral structure of trade

16. A more detailed decomposition of each country's trade partners is provided in Figures 3.1 to 3.46 which include all the 45 countries/zones covered in the 2005 trade matrix as well as the euro area OECD members. For instance for the United States (Figure 3.1), the two upper bar charts provide an indication of the sensitivity of each country's exports to a change in US import demand: the first one ranks countries according to the absolute size of US demand for their exports, whereas the second one ranks countries according to the relative importance of US demand for their exports. Thus, bar chart (a) shows that Canada, China, Mexico and Dynamic Asia together account for just under half of US imports, while in relative terms the second bar chart (b) shows that the United States is especially important as an export market for both Canada and Mexico, accounting for more than three-quarters of these countries' exports. The lower bar chart (c) provides an indication of the most important markets for US exports in absolute terms, whereas the bottom bar chart (d) shows those countries which are most reliant on US exports in relation to their total imports. China's imports come mainly from the rest of Asia, the United States and oil producing countries, and it accounts for more than $15 \%$ of total exports of its Asian partners (almost a quarter of exports from non OECD dynamic Asian economies) (Figure 3.36). The United States is by far the main export market for China and receives for about one-third of its exports. In addition Figure 3.3 shows the same breakdown for the euro area external trade.

17. The panel (c) of each figure also helps compare the geographical trade diversification of each country, highlighting the extreme cases of Canada and Mexico where more than $80 \%$ of exports go to a single partner: the United States. On the other hand German external trade appears among the most diversified with the two main trade partners France and the United States each accounting for only $10 \%$ of German exports. 
Figure 3.1. Geographical structure of goods and services trade of the United States (USA)

a) Percentage decomposition of USA goods and services imports by exporting country

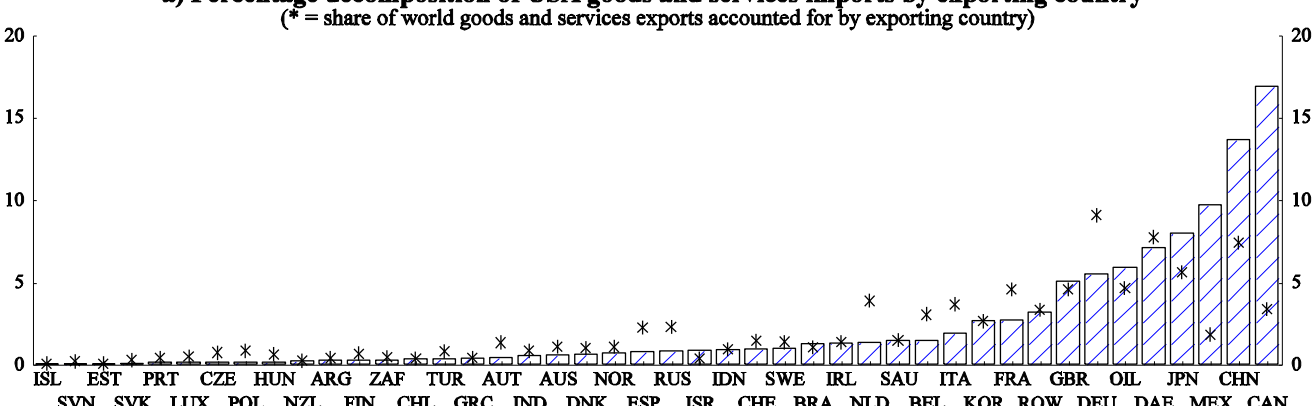

SVN SVK LUX POL NZL FIN CHL GRC IND DNK ESP ISR CHE BRA NLD BEL KOR ROW DEU DAE MEX CAN

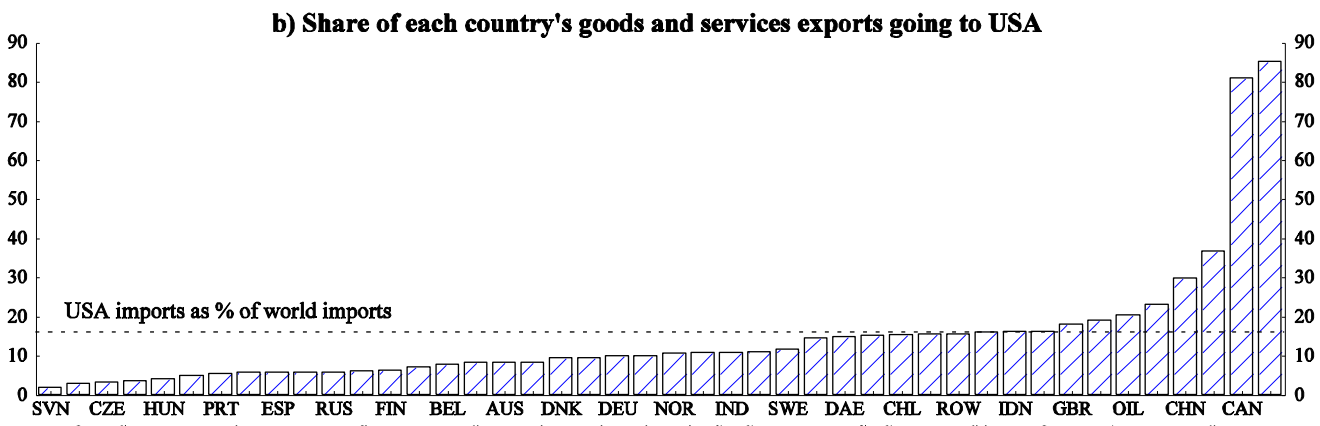

POL SVK LUX AUT NLD EST TUR ISL ITA FRA ZAF ARG CHE NZL GRC IRL SAU KOR BRA JPN ISR MEX

c) Percentage decomposition of USA goods and services exports by importing country

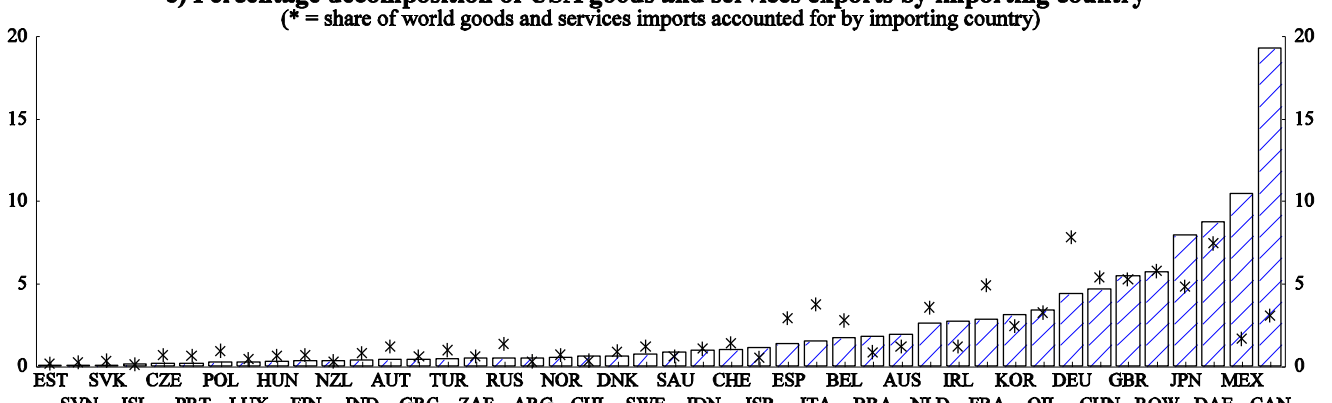

SVN ISL PRT LUX FIN IND GRC ZAF ARG CHL SWE IDN ISR ITA BRA NLD FRA OIL CHN ROW DAE CAN

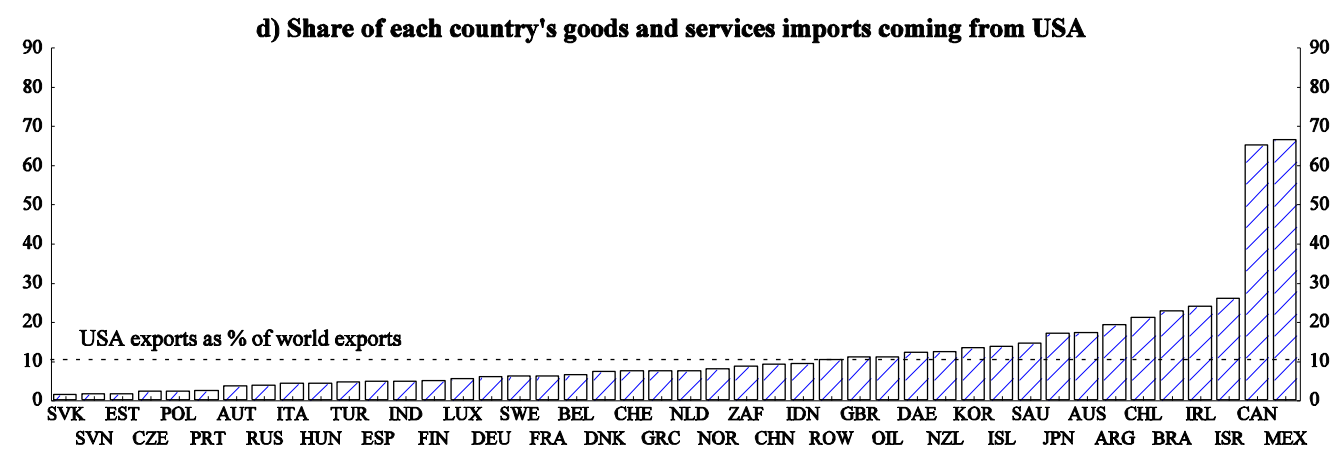


Figure 3.2. Geographical structure of goods and services trade of Japan (JPN)

a) Percentage decomposition of JPN goods and services imports by exporting country

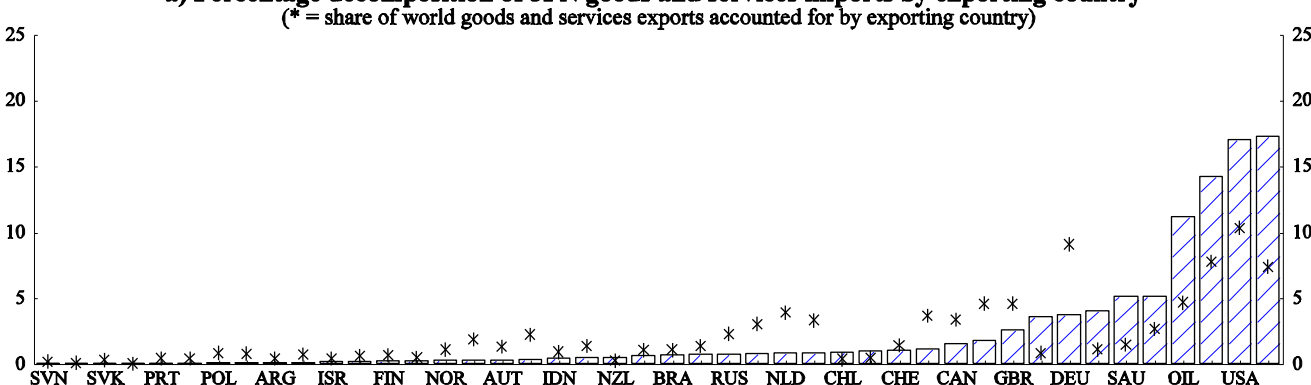
EST ISL GRC TUR CZE HUN LUX MEX ESP SWE DNK IRL BEL ROW ZAF ITA FRA IND AUS KOR DAE CHN

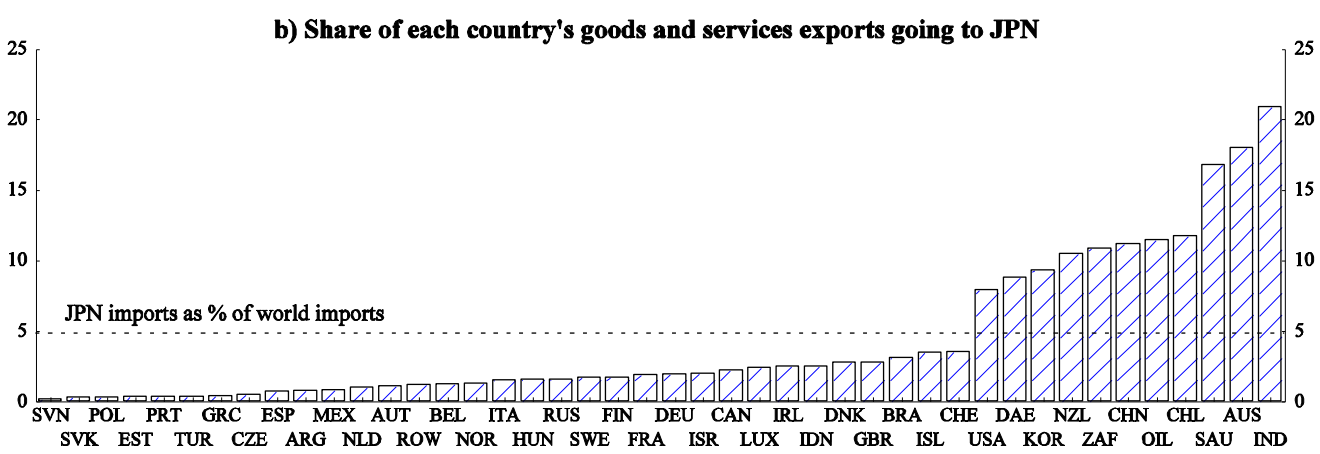

c) Percentage decomposition of JPN goods and services exports by importing country

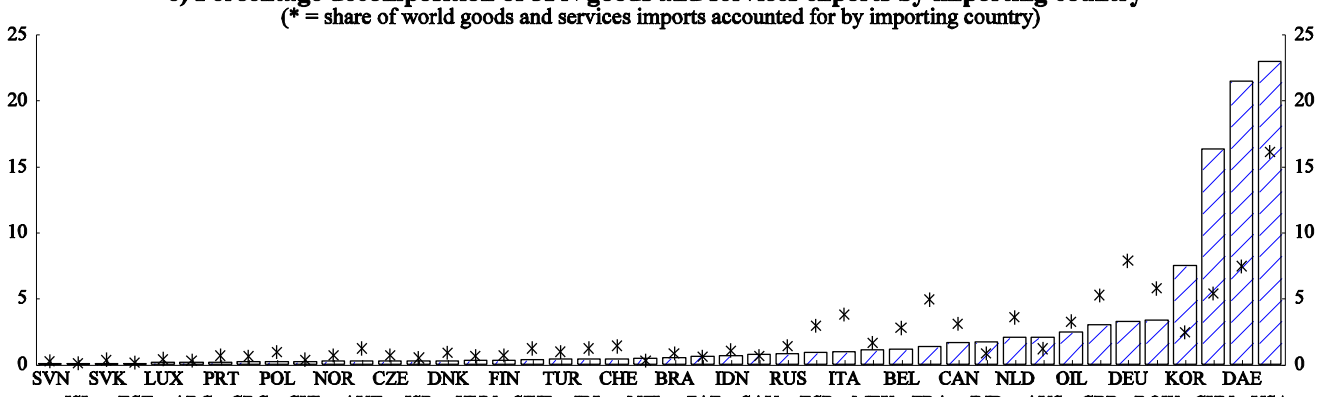

ISL EST ARG GRC CHL AUT ISR HUN SWE IRL NZL ZAF SAU ESP MEX FRA IND AUS GBR ROW CHN USA

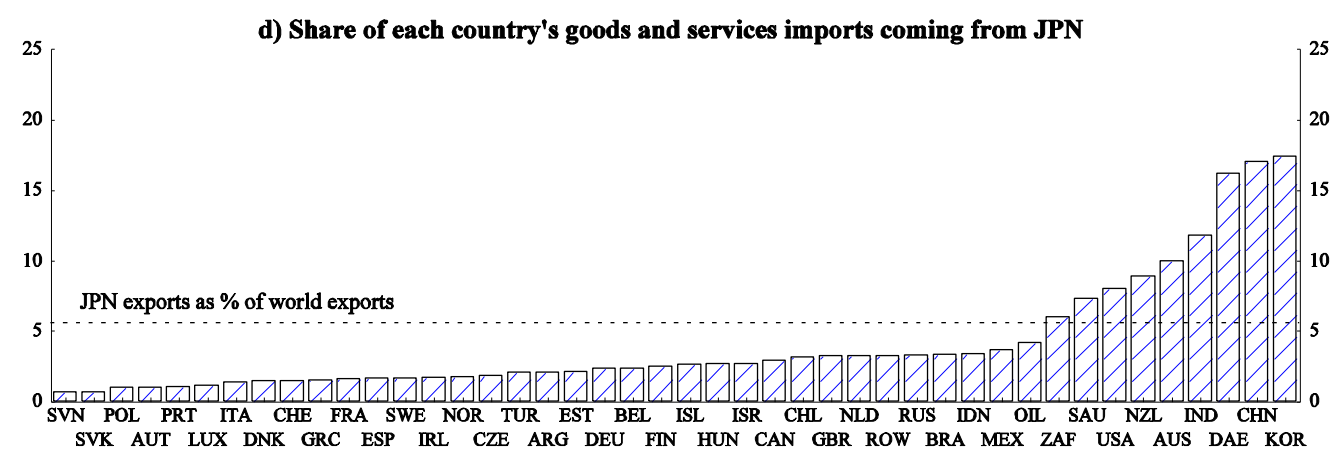


Figure 3.3. Geographical structure of goods and services trade of the Euro Area 14 (EA14), excluding intra-trade (1)

a) Percentage decomposition of EA14 goods and services imports by exporting country
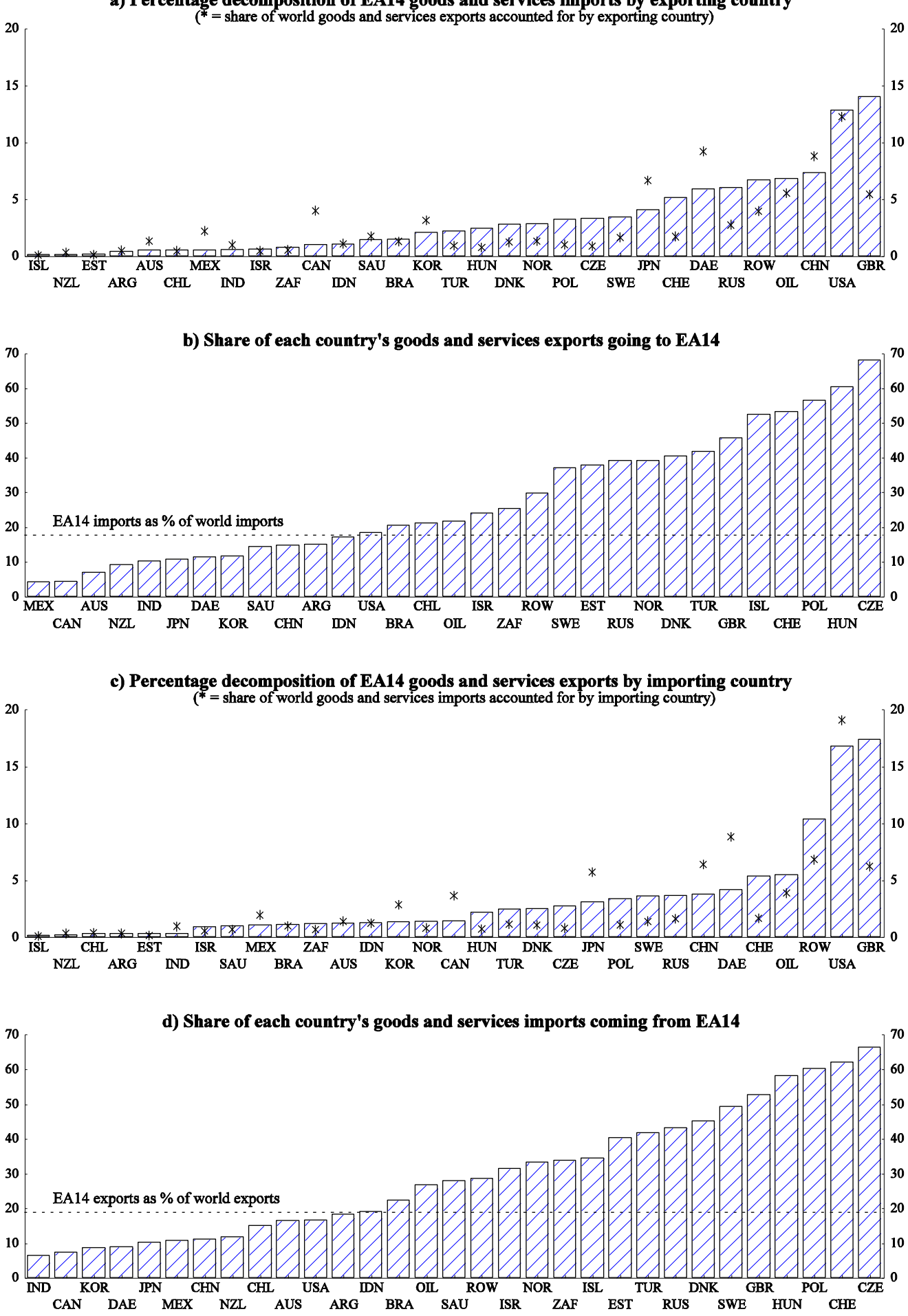

1. On this panel, world trade $G \& S$ excludes intra-euro area trade, which is set to zero. 
Figure 3.4. Geographical structure of goods and services trade of Germany (DEU)

a) Percentage decomposition of DEU goods and services imports by exporting country

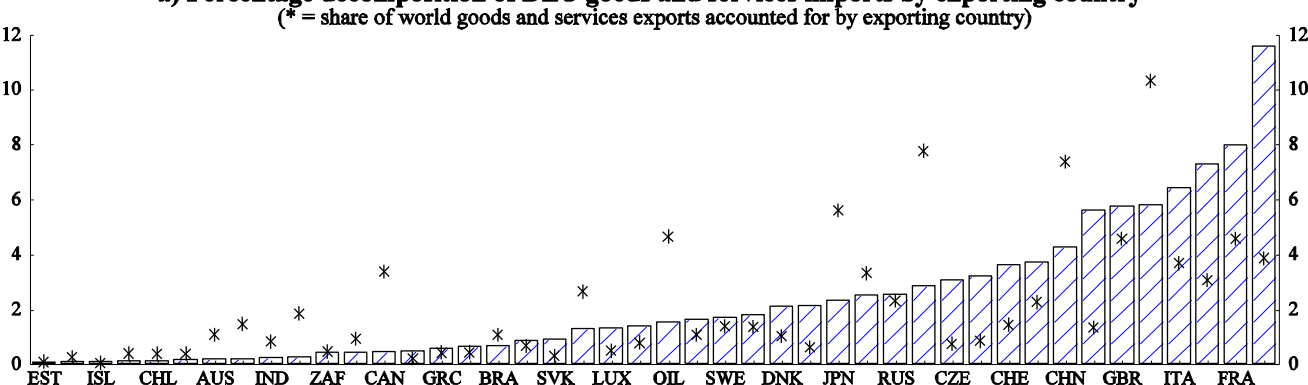

NZL ARG ISR SAU MEX IDN SVN PRT FIN KOR TUR NOR IRL HUN ROW DAE POL ESP AUT USA BEL NLD

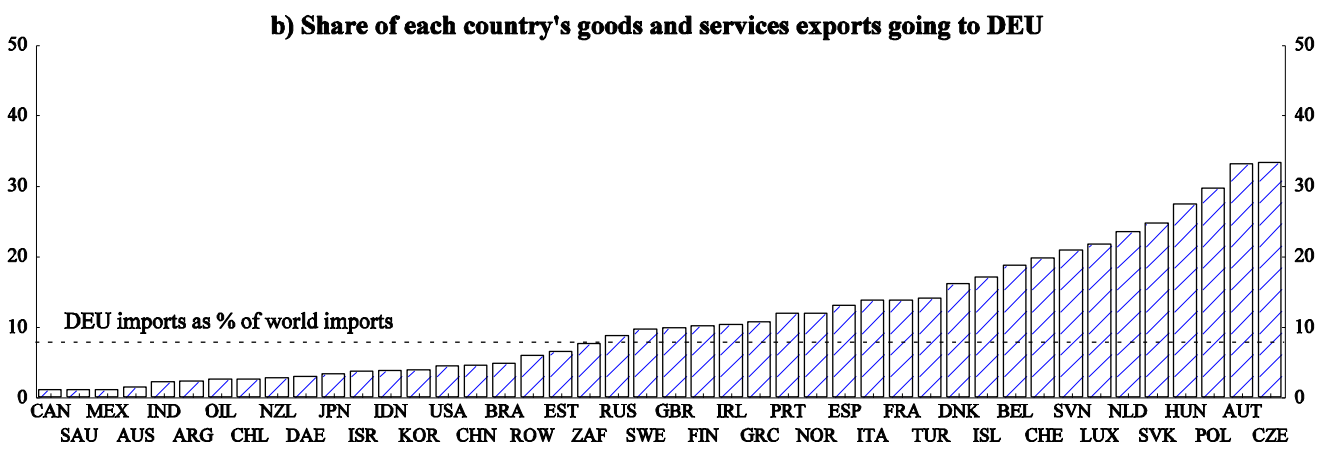

c) Percentage decomposition of DEU goods and services exports by importing country
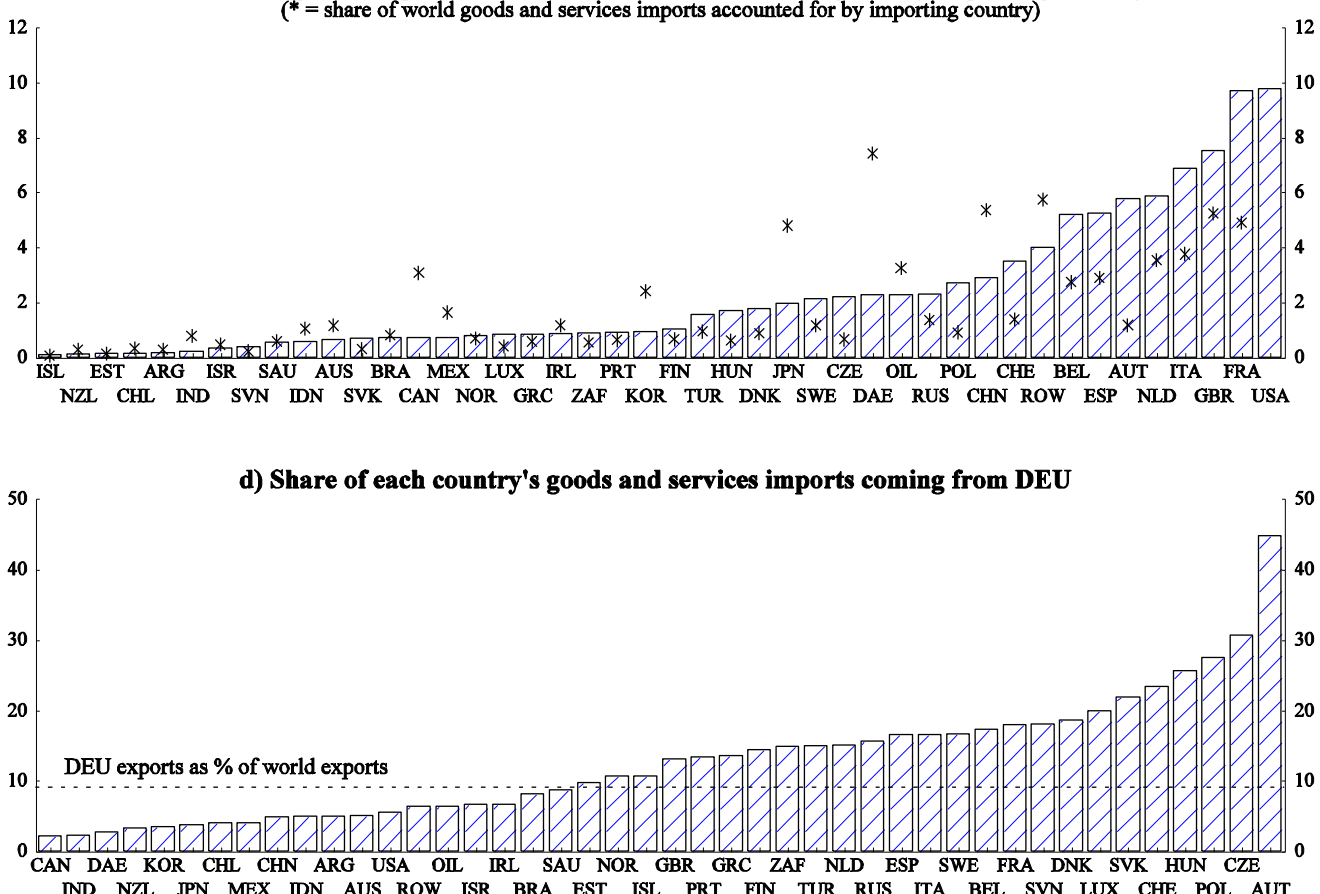
Figure 3.5. Geographical structure of goods and services trade of France (FRA)

a) Percentage decomposition of FRA goods and services imports by exporting country

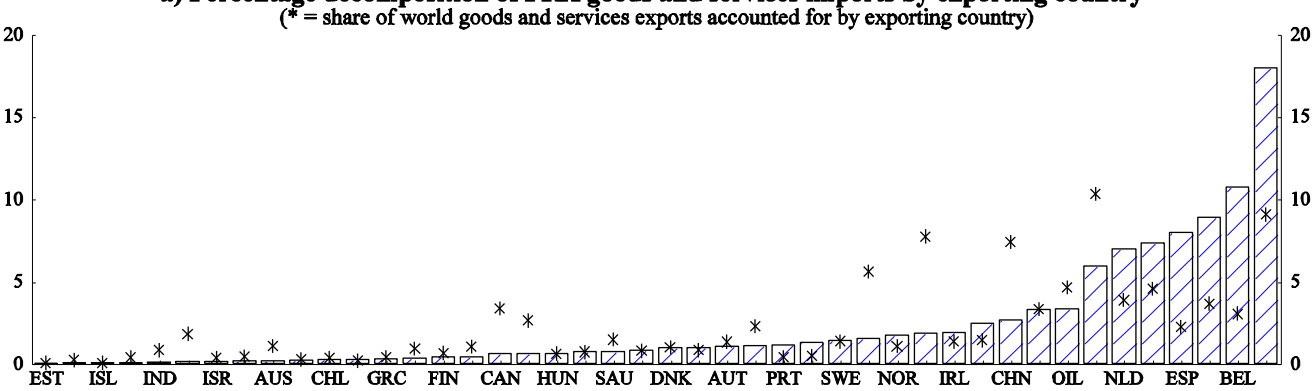
NZL ARG MEX ZAF SVK SVN IDN BRA KOR CZE TUR POL RUS LUX JPN DAE CHE ROW USA GBR ITA DEU

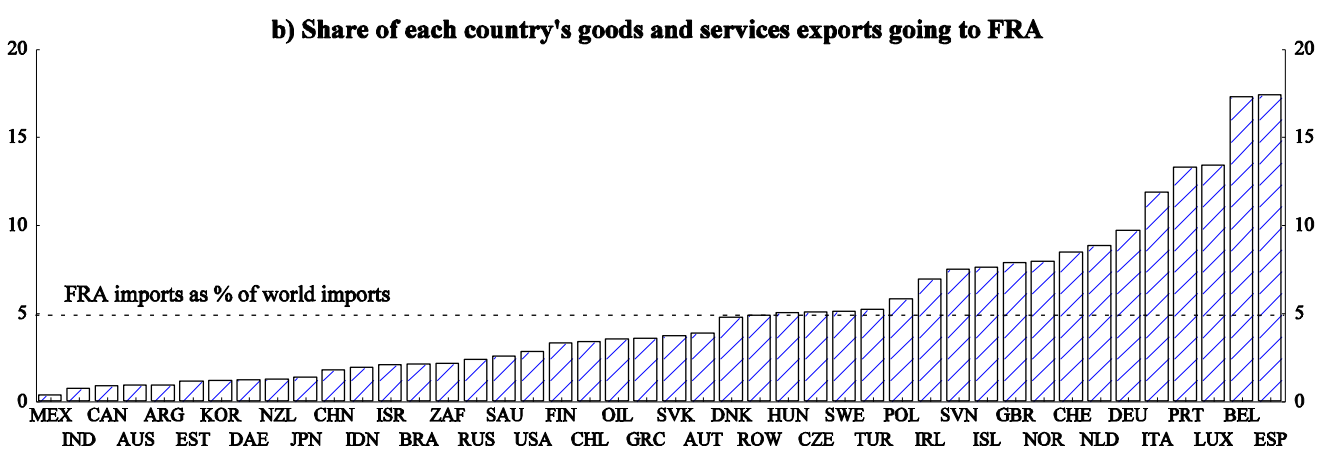

c) Percentage decomposition of FRA goods and services exports by importing country
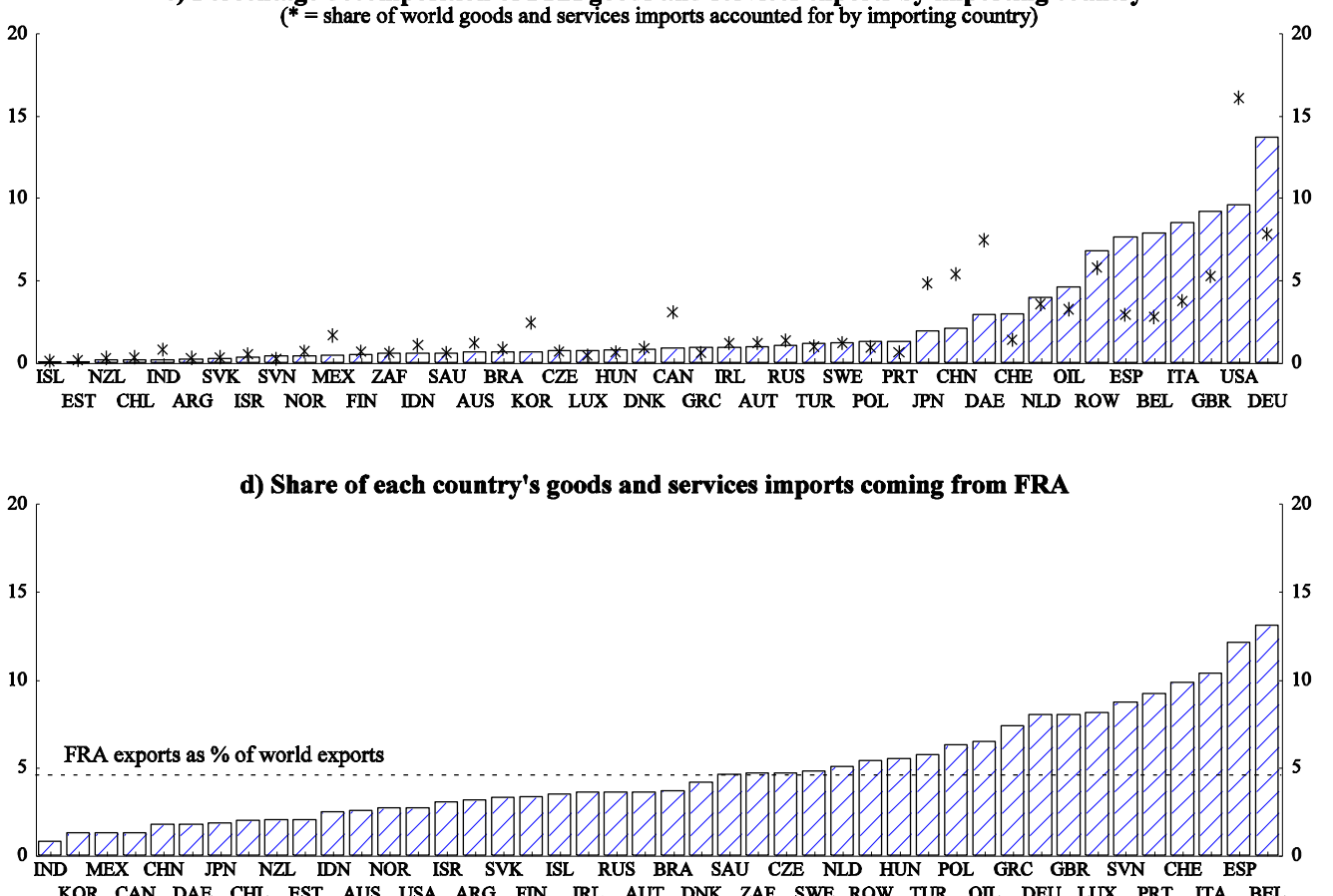
Figure 3.6. Geographical structure of goods and services trade of Italy (ITA)

a) Percentage decomposition of ITA goods and services imports by exporting country $*^{*}=$ share of world goods and services exports accounted for by exporting country)

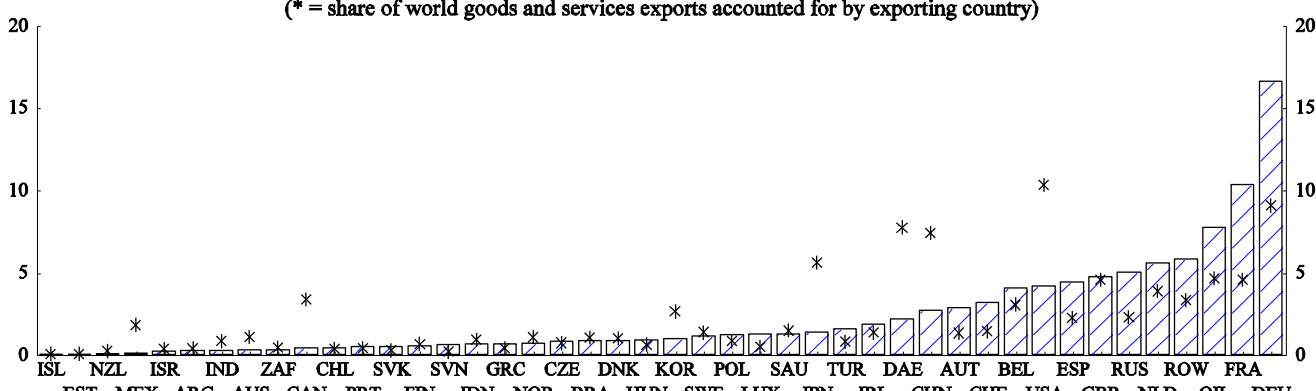

EST MEX ARG AUS CAN PRT FIN IDN NOR BRA HUN SWE LUX JPN IRL CHN CHE USA GBR NLD OIL DEU

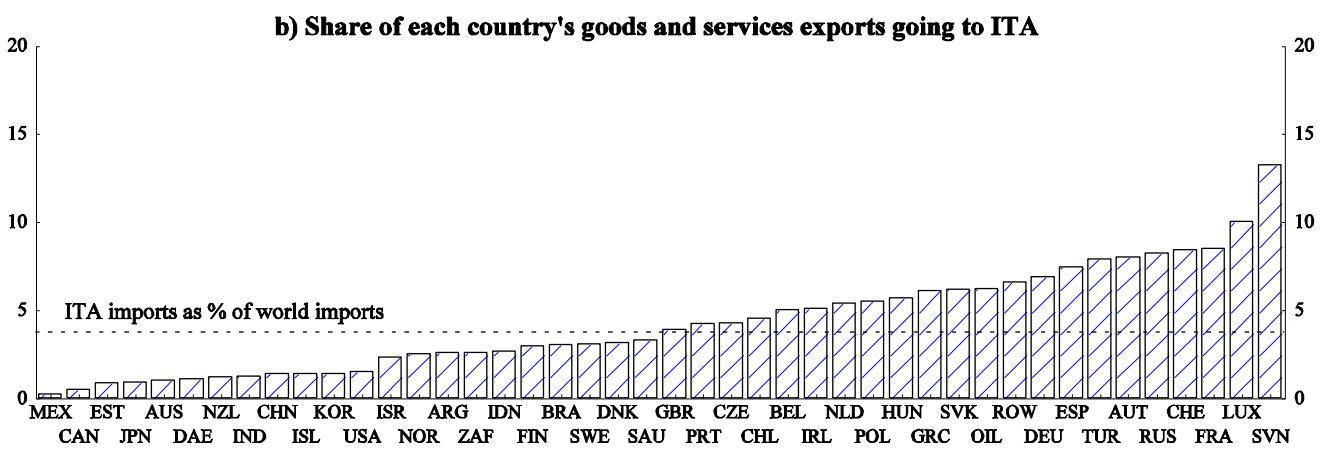

c) Percentage decomposition of ITA goods and services exports by importing country
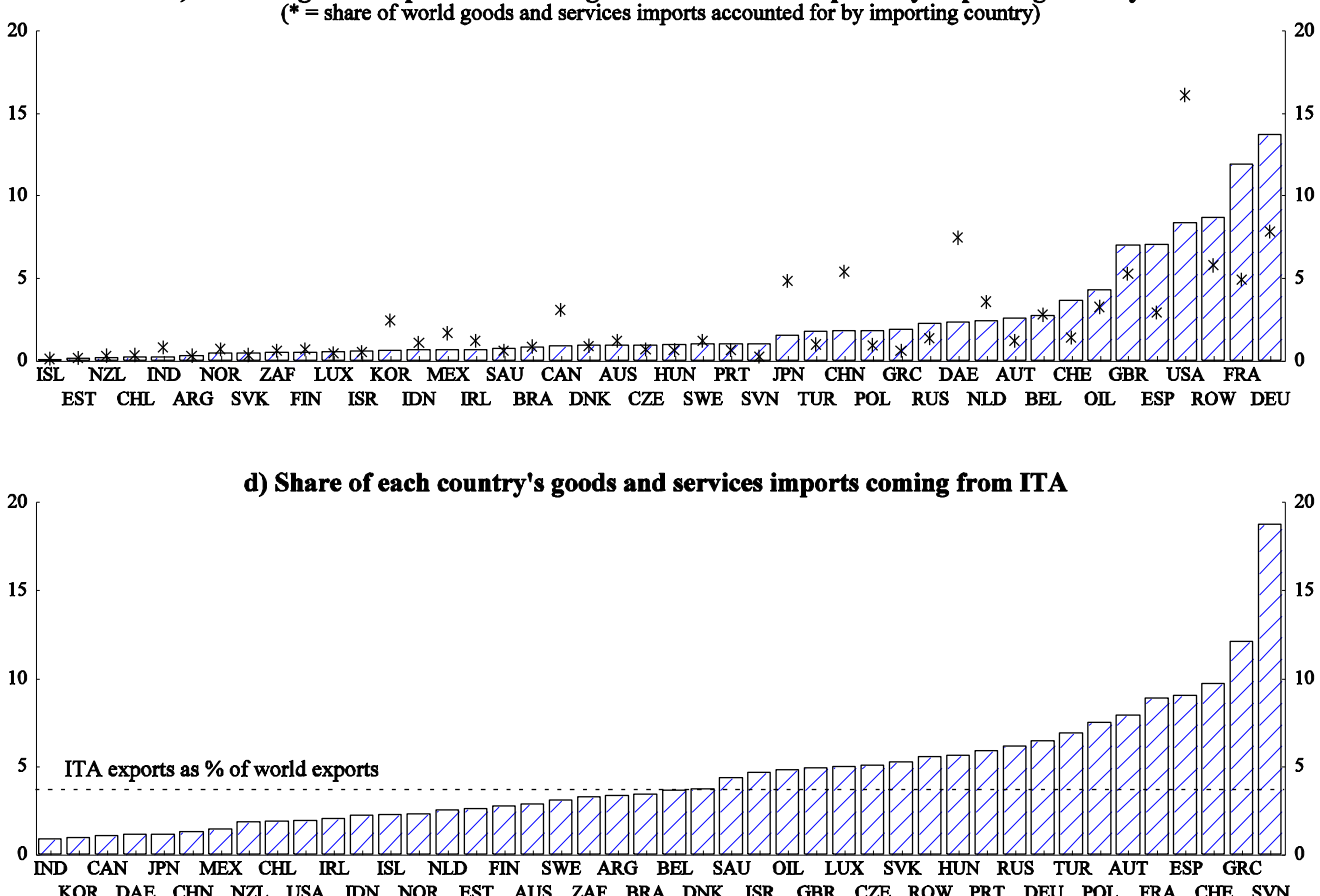
Figure 3.7. Geographical structure of goods and services trade of the United Kingdom (GBR) a) Percentage decomposition of GBR goods and services imports by exporting country

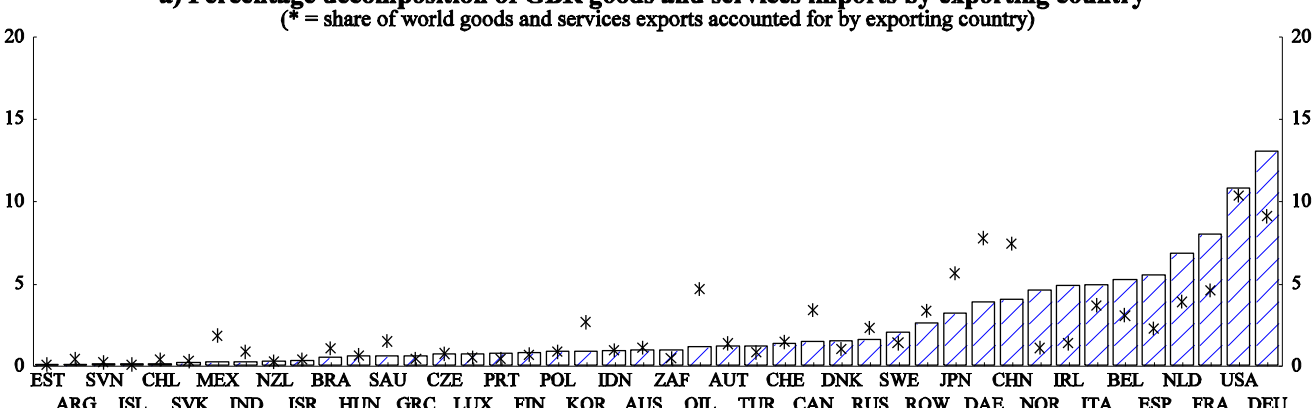

ARG ISL SVK IND ISR HUN GRC LUX FIN KOR AUS OIL TUR CAN RUS ROW DAE NOR ITA ESP FRA DEU

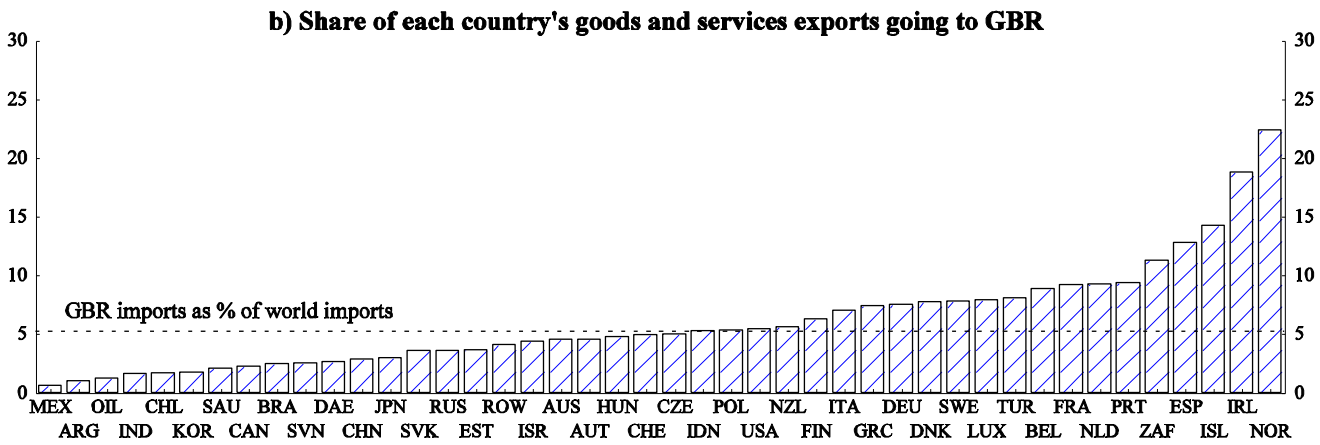

c) Percentage decomposition of GBR goods and services exports by importing country

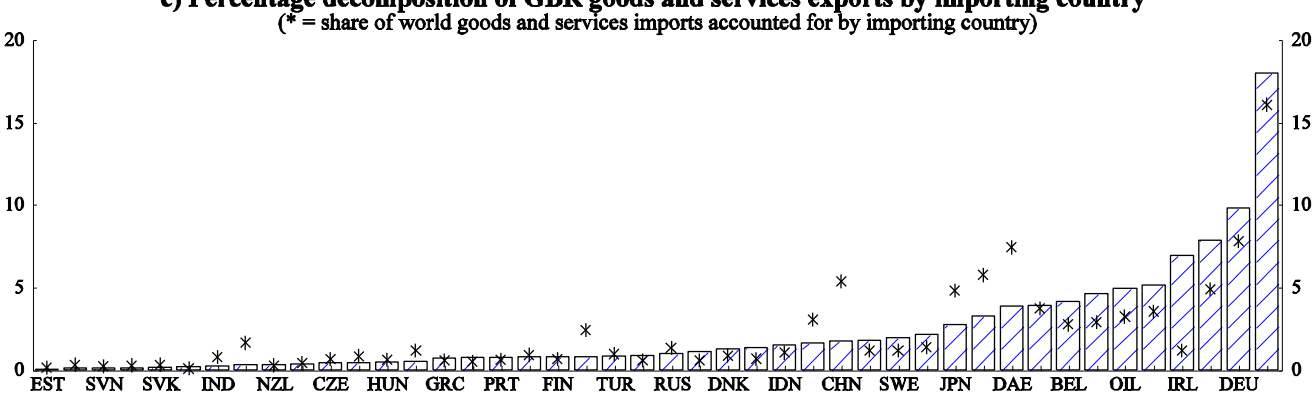

CHL ARG ISL MEX LUX BRA AUT ISR POL KOR SAU ZAF NOR CAN AUS CHE ROW ITA FSP NLD FRA USA

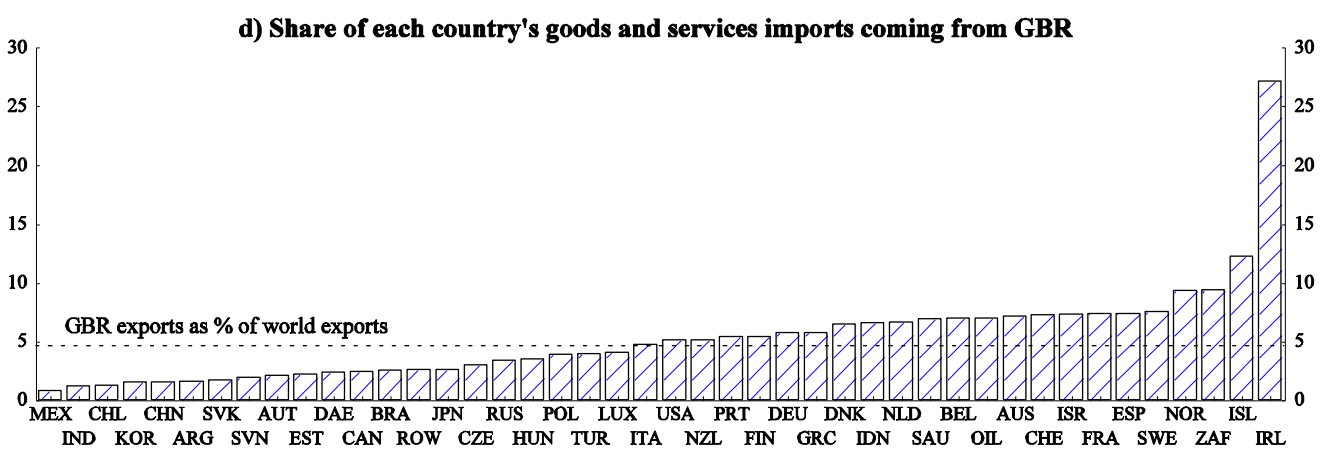


Figure 3.8. Geographical structure of goods and services trade of Canada (CAN)

a) Percentage decomposition of CAN goods and services imports by exporting country

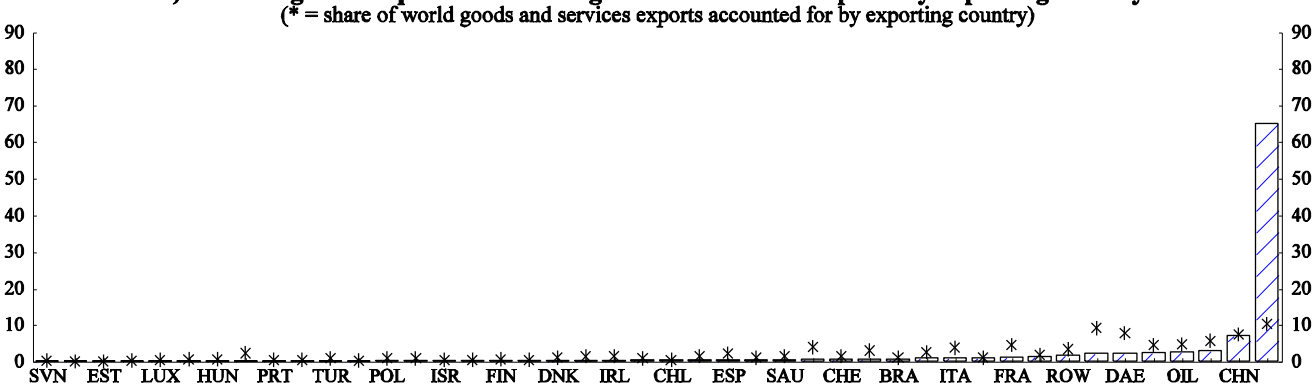

ISL SVK CZE RUS ARG NZL IND GRC ZAF AUT IDN SWE AUS NLD BEL KOR NOR MEX DEU GBR JPN USA

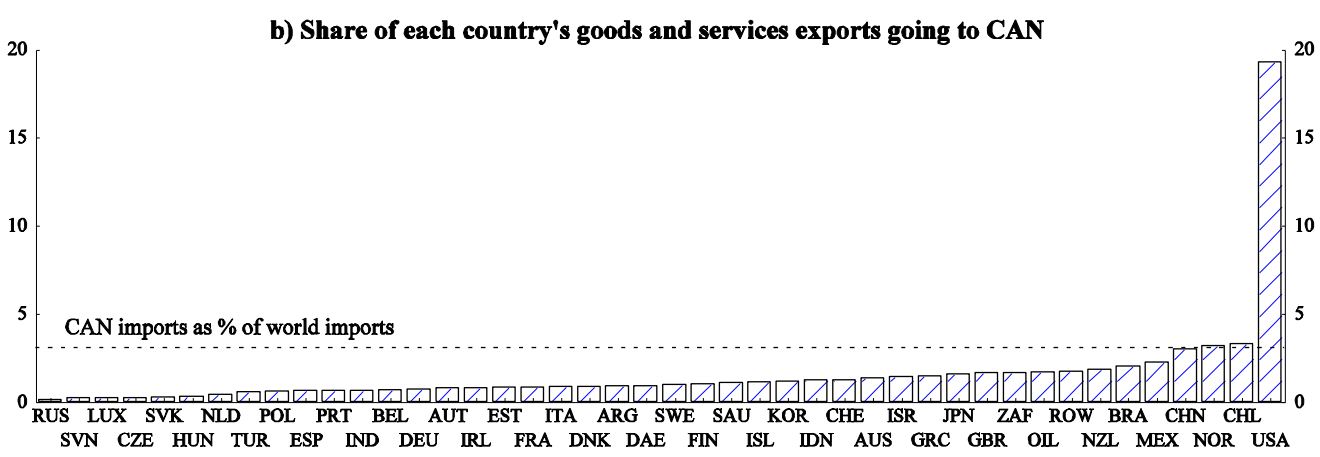

c) Percentage decomposition of CAN goods and services exports by importing country

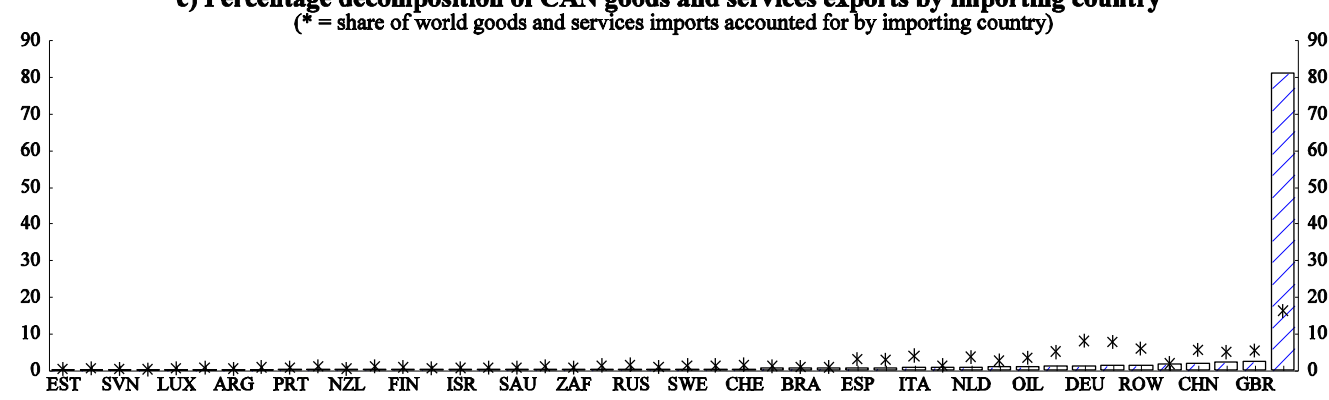

SVK ISL HUN CZE POL TUR CHL GRC DNK AUT IND IRL IDN NOR BEL AUS KOR FRA DAE MEX JPN USA

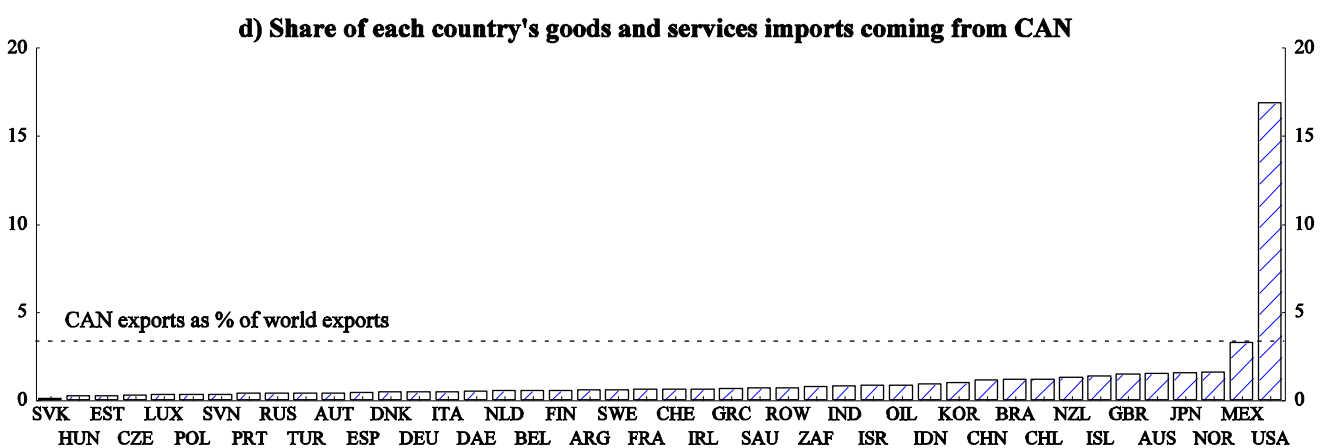


Figure 3.9. Geographical structure of goods and services trade of Australia (AUS)

a) Percentage decomposition of AUS goods and services imports by exporting country

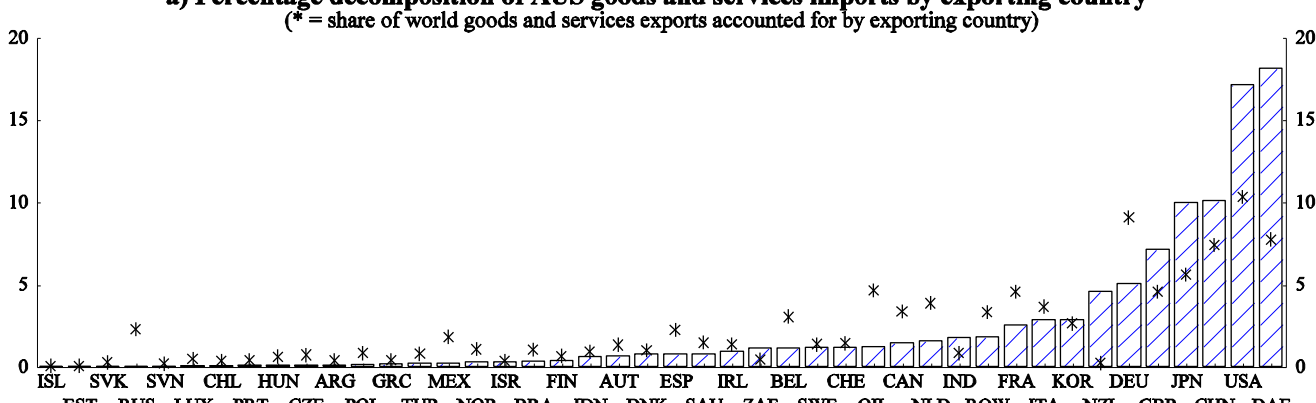

EST RUS LUX PRT CZE POL TUR NOR BRA IDN DNK SAU ZAF SWE OIL NLD ROW ITA NZL GBR CHN DAE

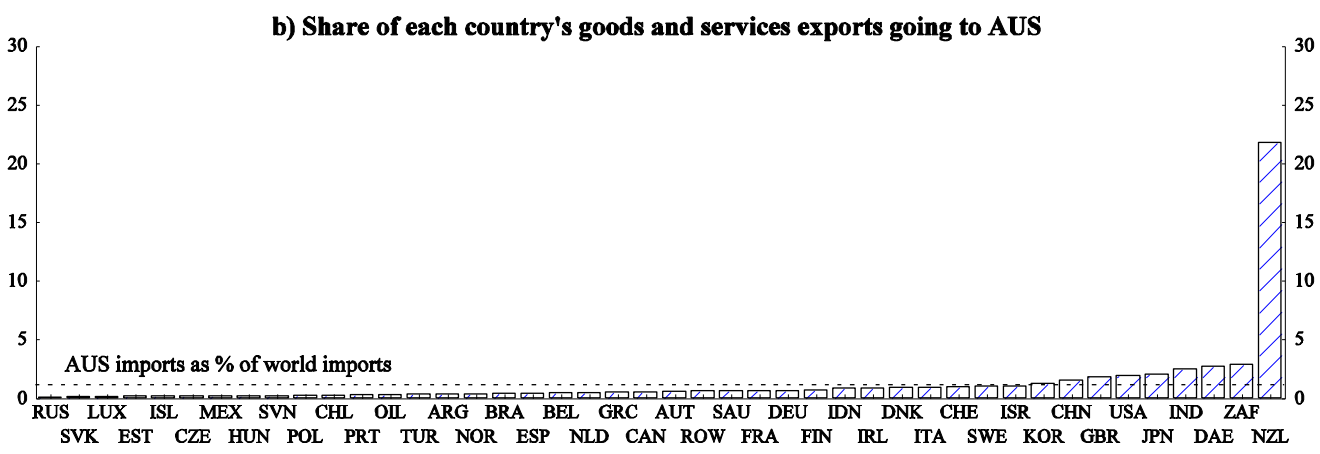

c) Percentage decomposition of AUS goods and services exports by importing country
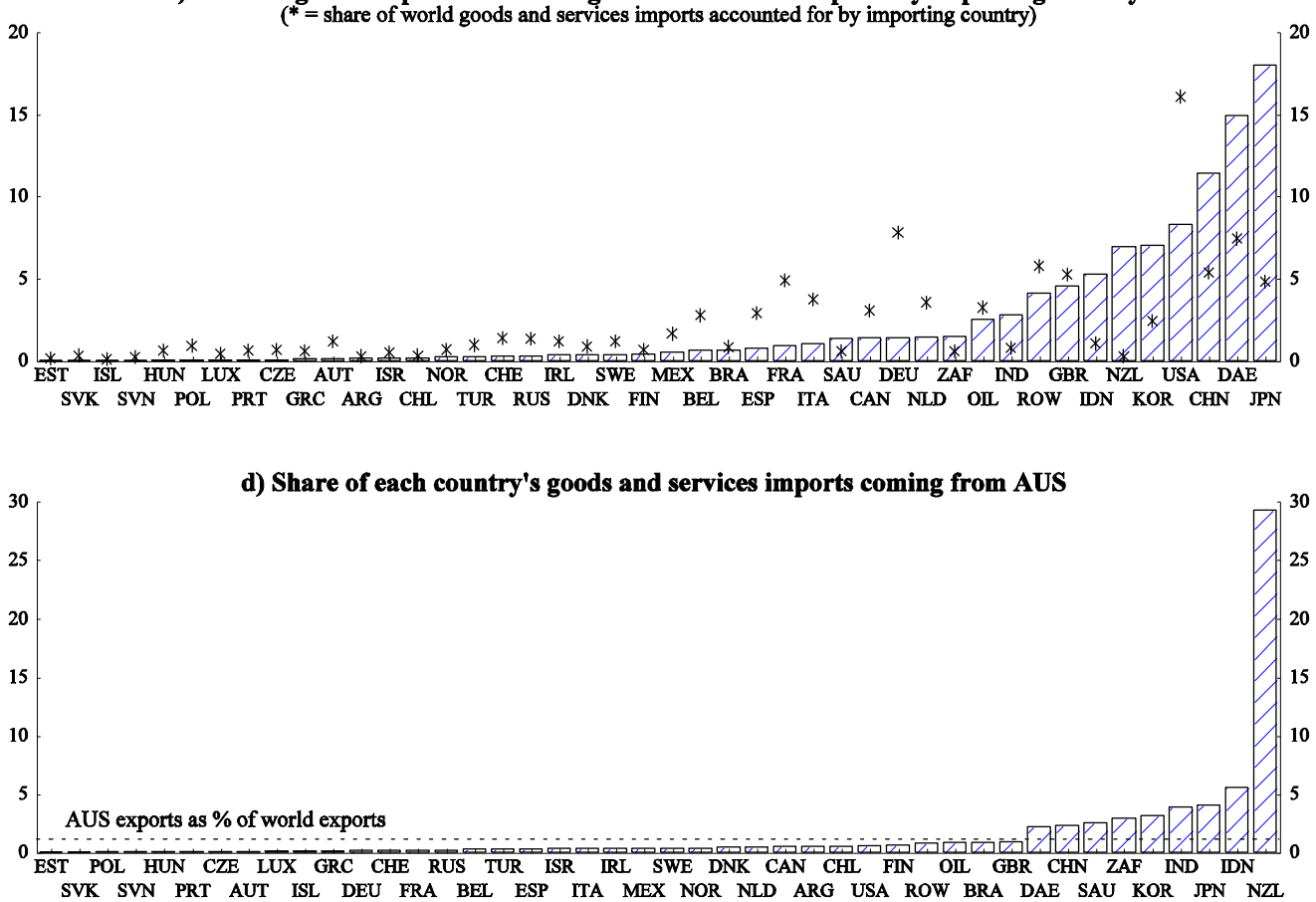
Figure 3.10. Geographical structure of goods and services trade of Austria (AUT)

a) Percentage decomposition of AUT goods and services imports by exporting country
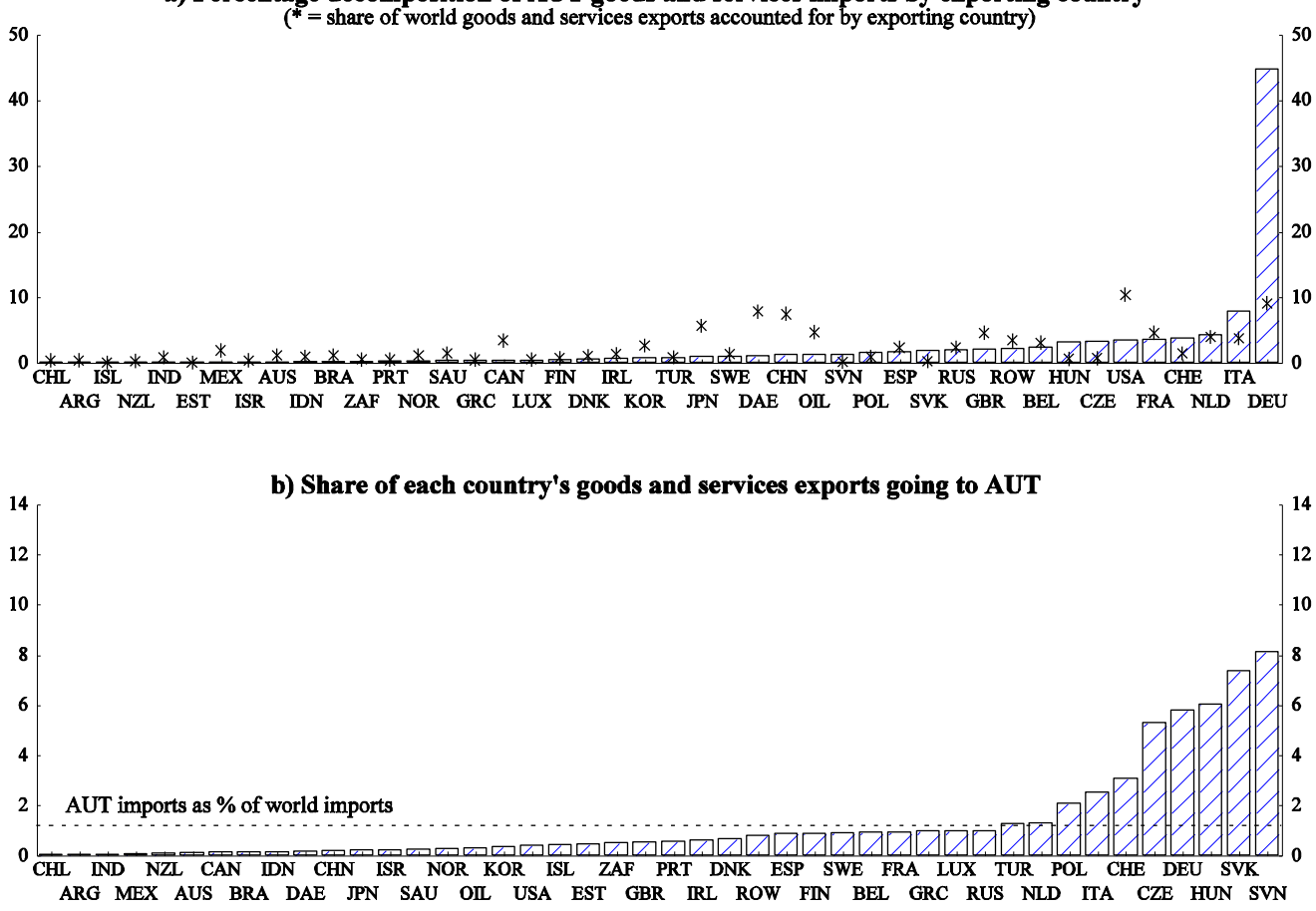

c) Percentage decomposition of AUT goods and services exports by importing country
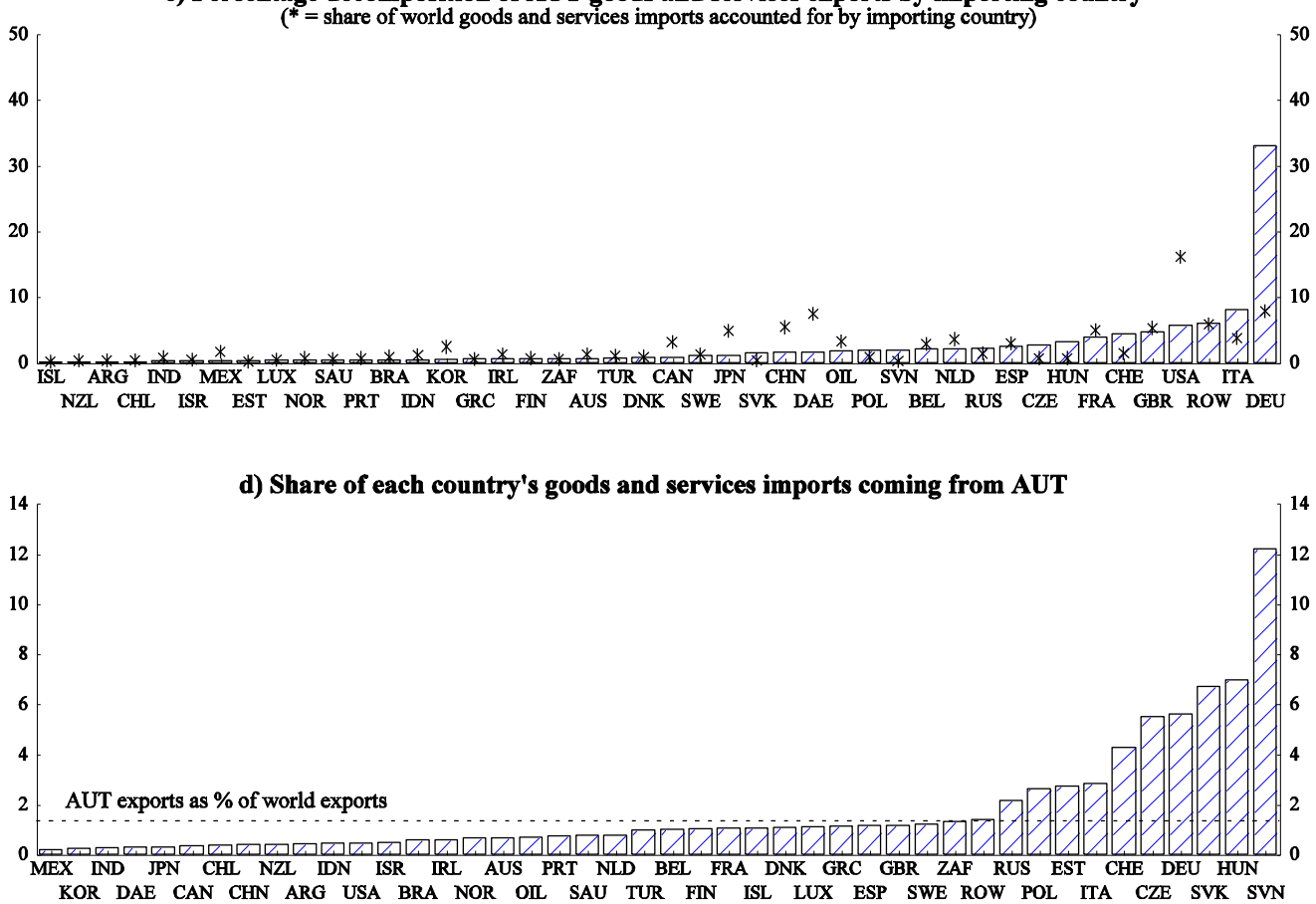
Figure 3.11. Geographical structure of goods and services trade of Belgium (BEL)

a) Percentage decomposition of BEL goods and services imports by exporting country

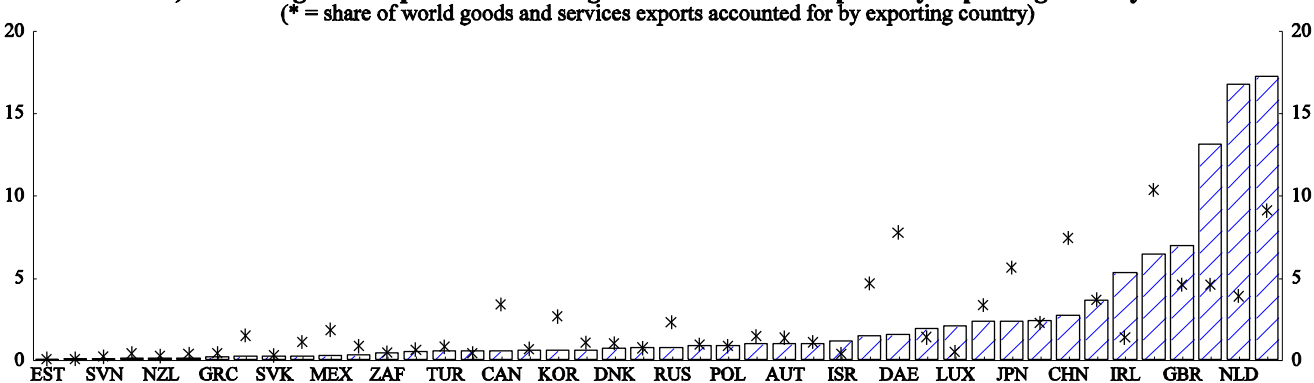

ISL ARG CHL SAU AUS IND HUN PRT FIN BRA CZE IDN CHE NOR OIL SWE ROW ESP ITA USA FRA DEU

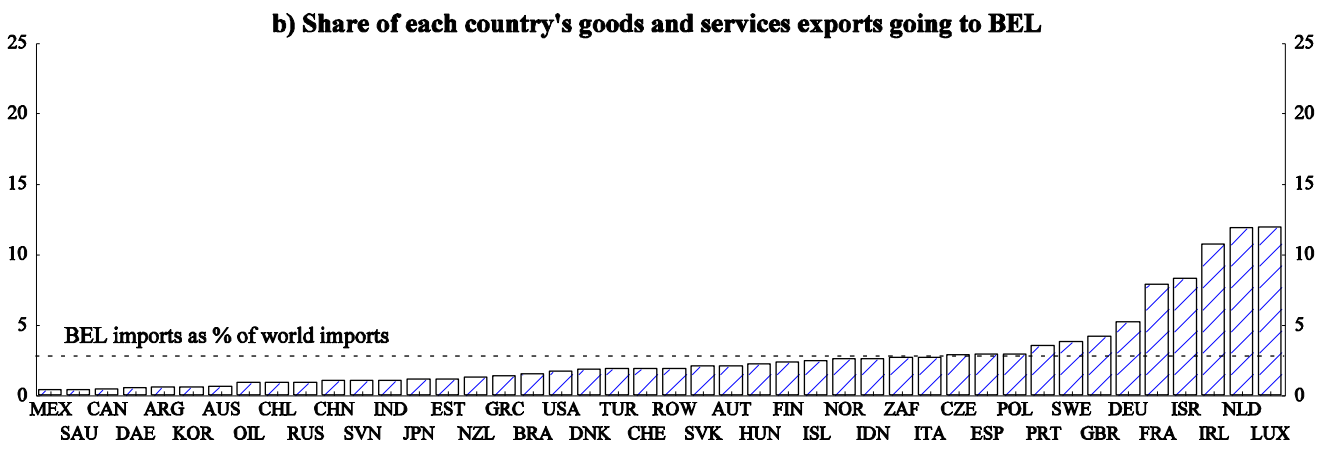

c) Percentage decomposition of BEL goods and services exports by importing country
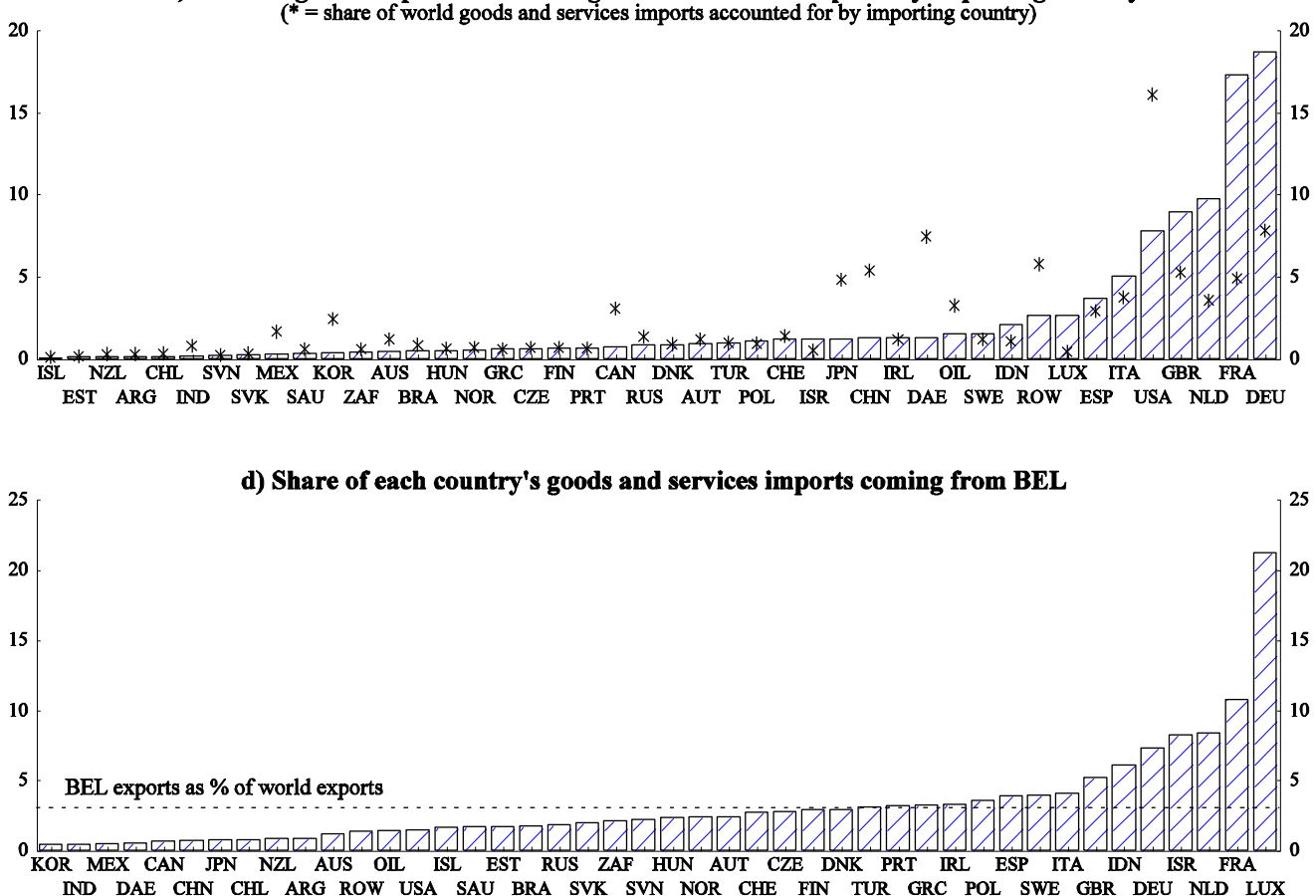
Figure 3.12. Geographical structure of goods and services trade of Chile (CHL)

a) Percentage decomposition of CHL goods and services imports by exporting country

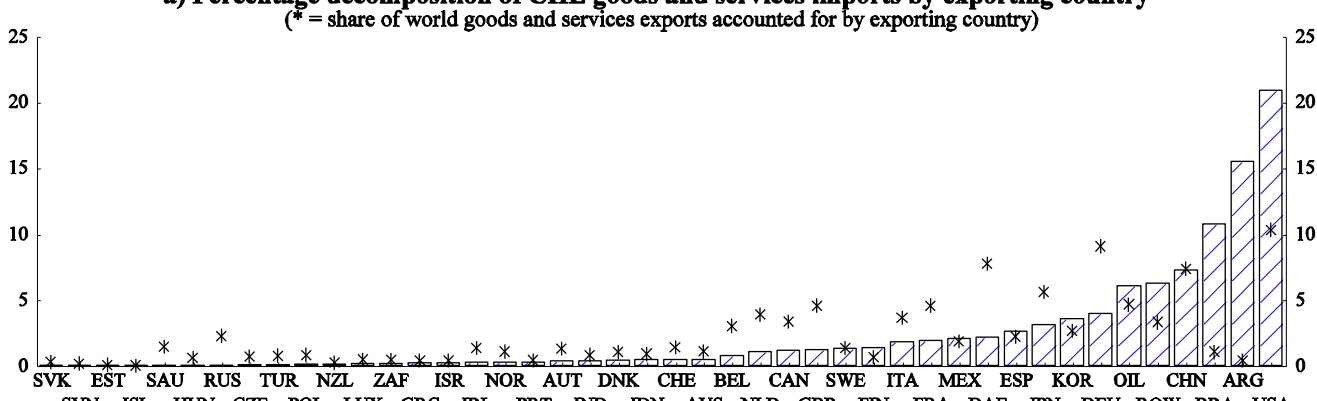

SVN ISL HUN CZE POL LUX GRC IRL PRT IND IDN AUS NLD GBR FIN FRA DAE JPN DEU ROW BRA USA

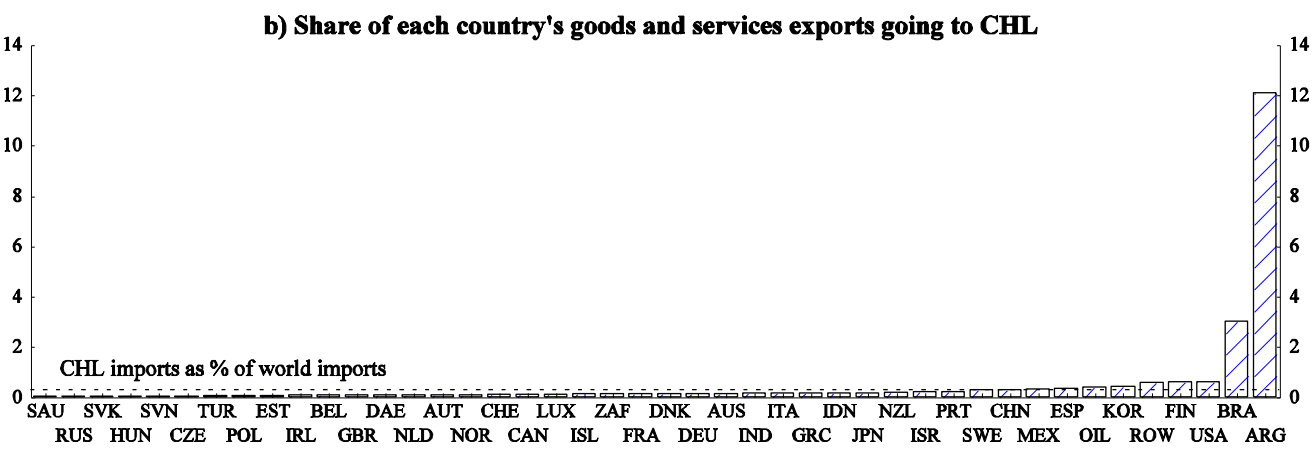

c) Percentage decomposition of CHL goods and services exports by importing country

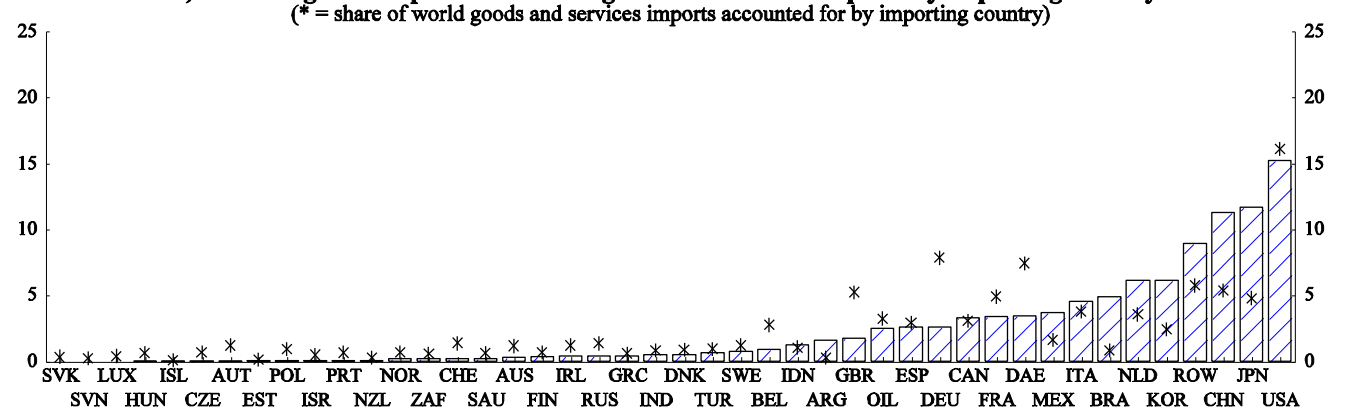

d) Share of each country's goods and services imports coming from CHL
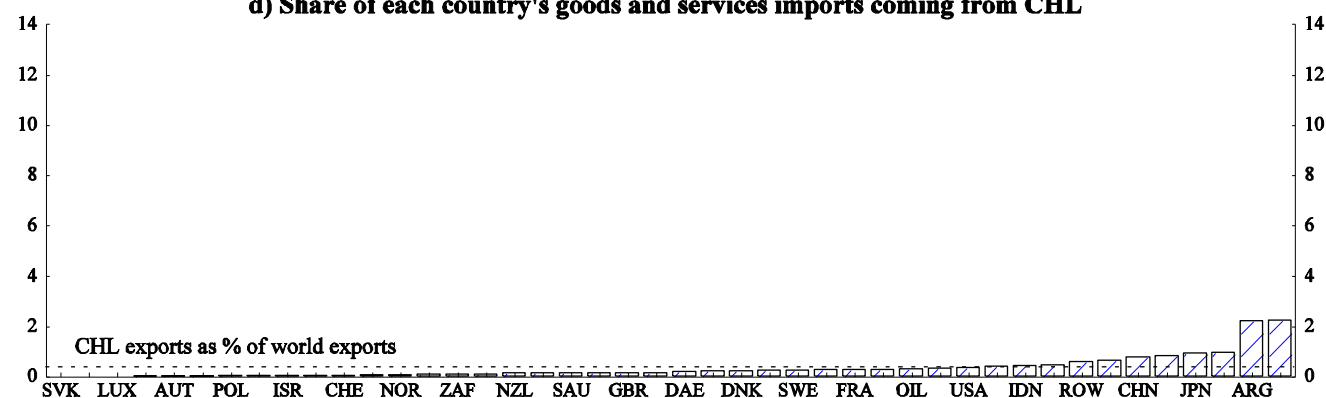

0 SVK LUX AUT POL ISR CHE NOR ZAF NZL SAU GBR DAE DNK SWE FRA OIL USA IDN ROW CHN JPN ARG SVN HUN CZE ISL PRT EST AUS RUS IRL BEL DEU FIN IND GRC TUR ESP CAN ITA NLD MEX KOR BRA 
Figure 3.13. Geographical structure of goods and services trade of the Czech Republic (CZE)

a) Percentage decomposition of CZE goods and services imports by exporting country

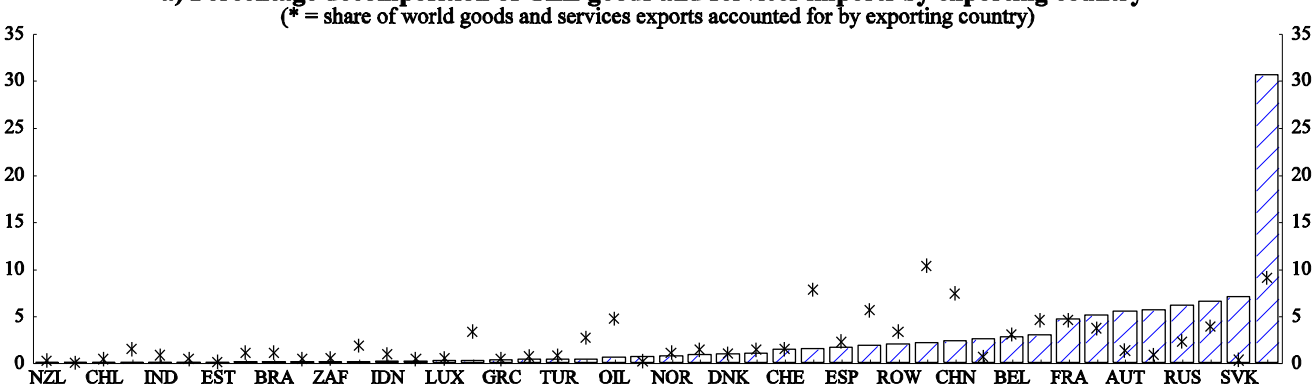

ISL SAU ARG AUS ISR MEX PRT CAN FIN KOR SVN IRL SWE DAE IPN USA HUN GBR ITA POL NLD DEU

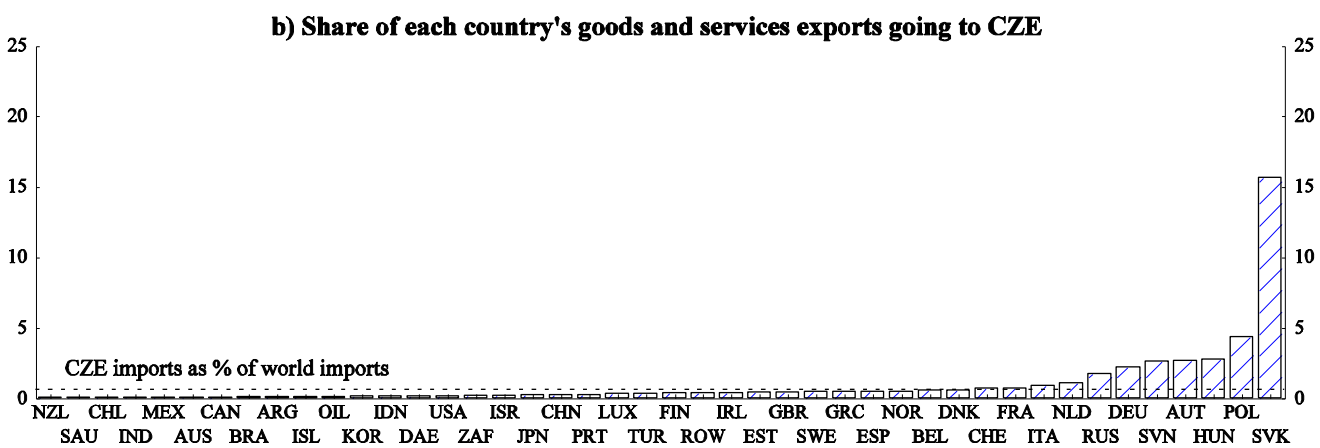

c) Percentage decomposition of CZE goods and services exports by importing country
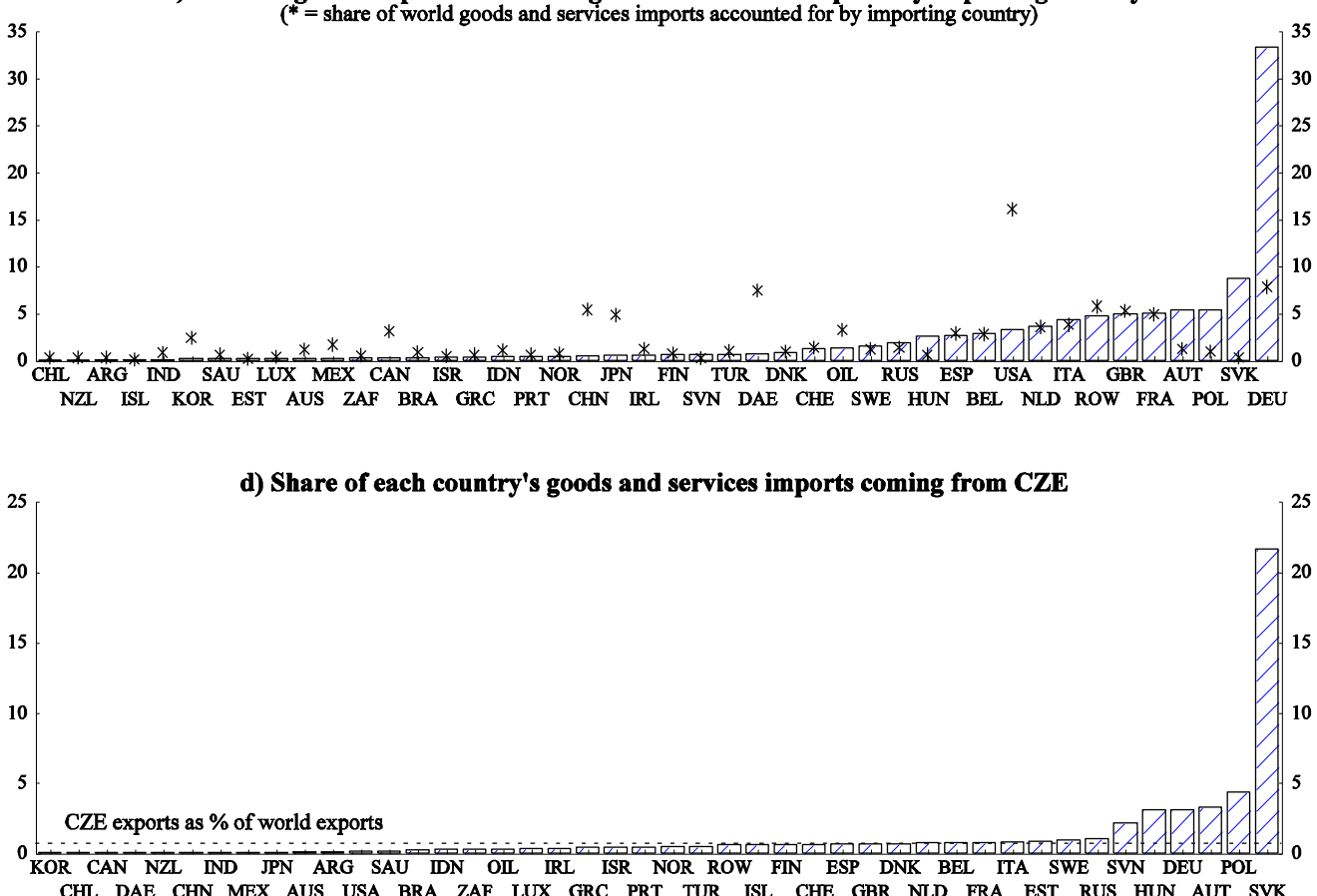
Figure 3.14. Geographical structure of goods and services trade of Denmark (DNK)

a) Percentage decomposition of DNK goods and services imports by exporting country

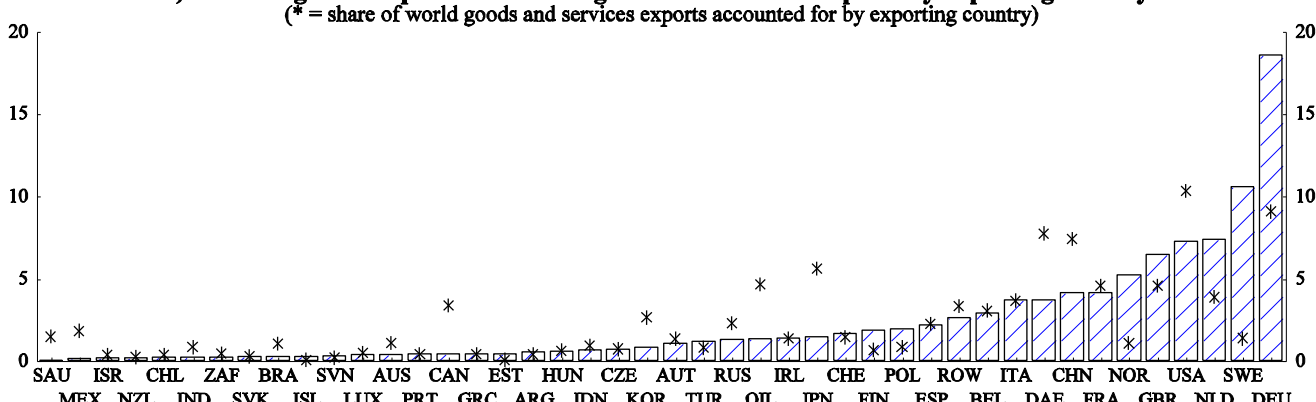

MEX NZL IND SVK ISL LUX PRT GRC ARG IDN KOR TUR OIL JPN FIN ESP BEL DAE FRA GBR NLD DEU

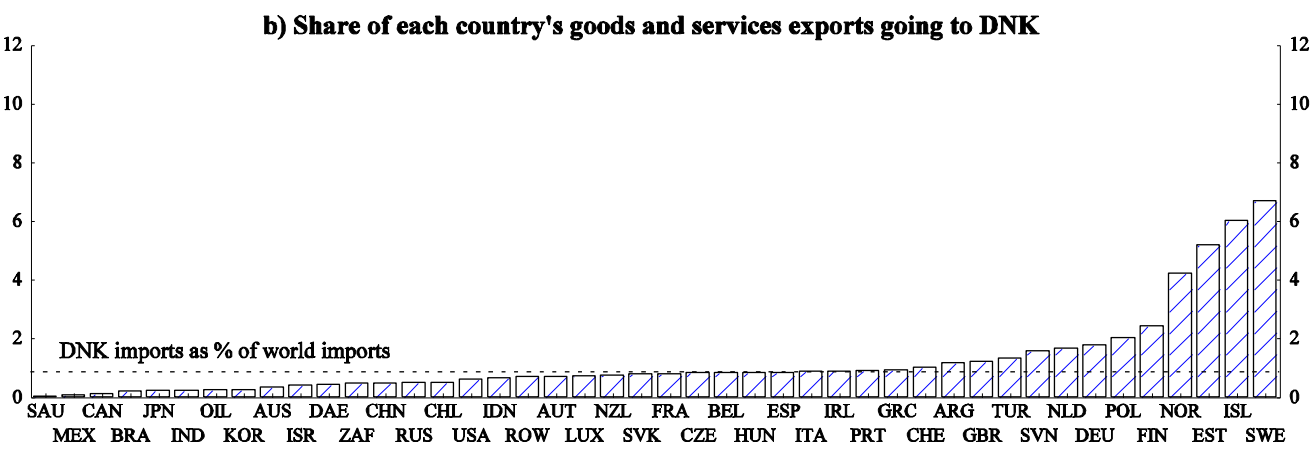

c) Percentage decomposition of DNK goods and services exports by importing country
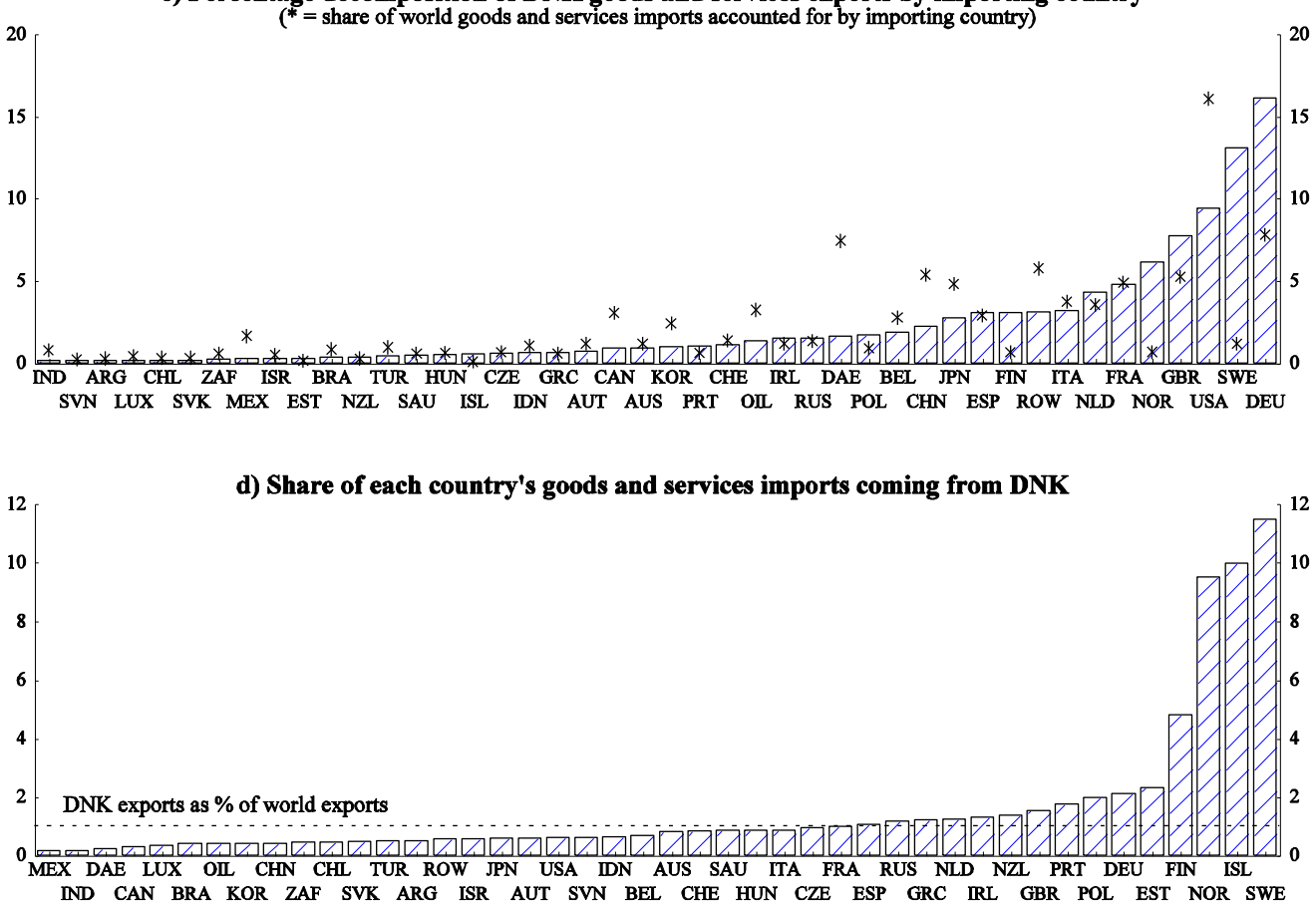
Figure 3.15. Geographical structure of goods and services trade of Finland (FIN)

a) Percentage decomposition of FIN goods and services imports by exporting country $(*=$ share of world goods and services exports accounted for by exporting country)

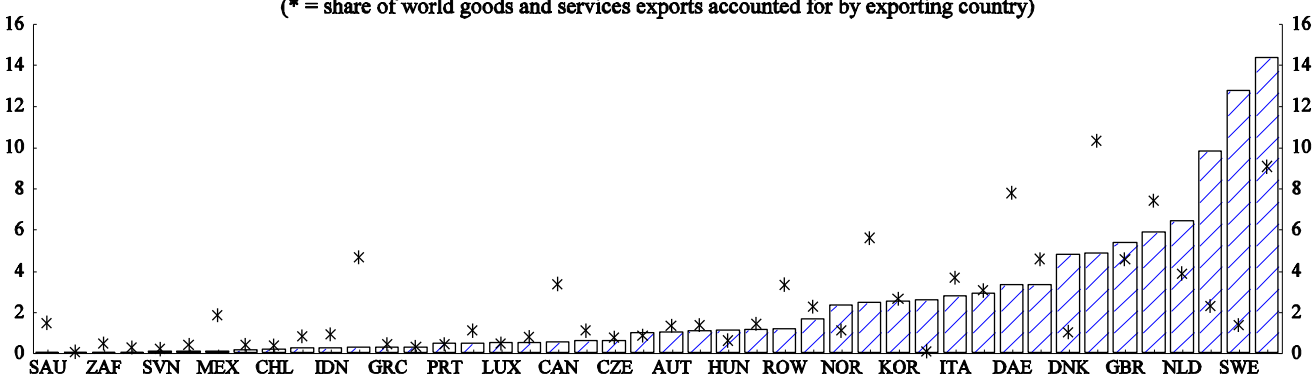

ISL NZL ARG ISR IND OI SVK BRA TUR AUS POL IRL CHE ESP IPN EST BEL RRA USA CHN RUS DEU

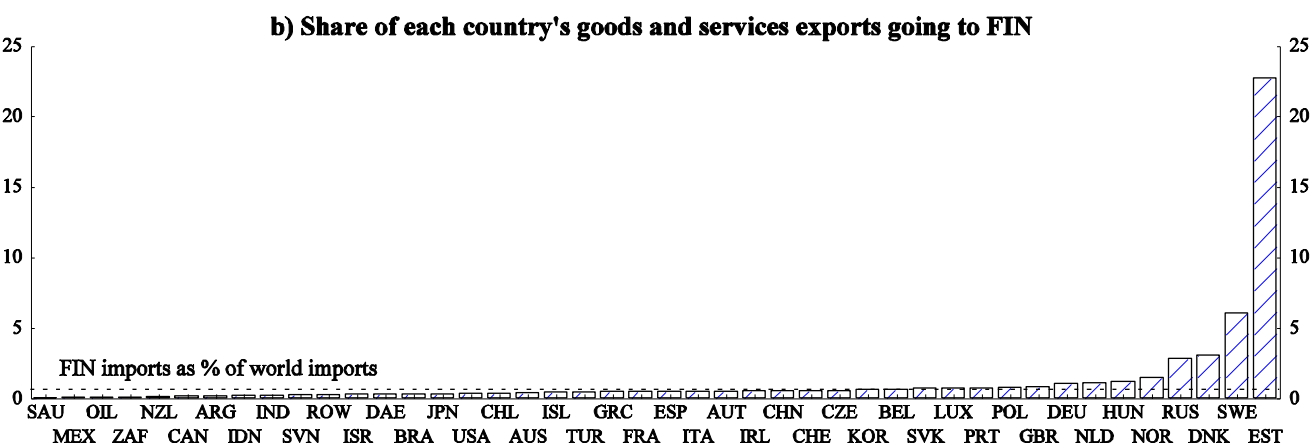

c) Percentage decomposition of FIN goods and services exports by importing country
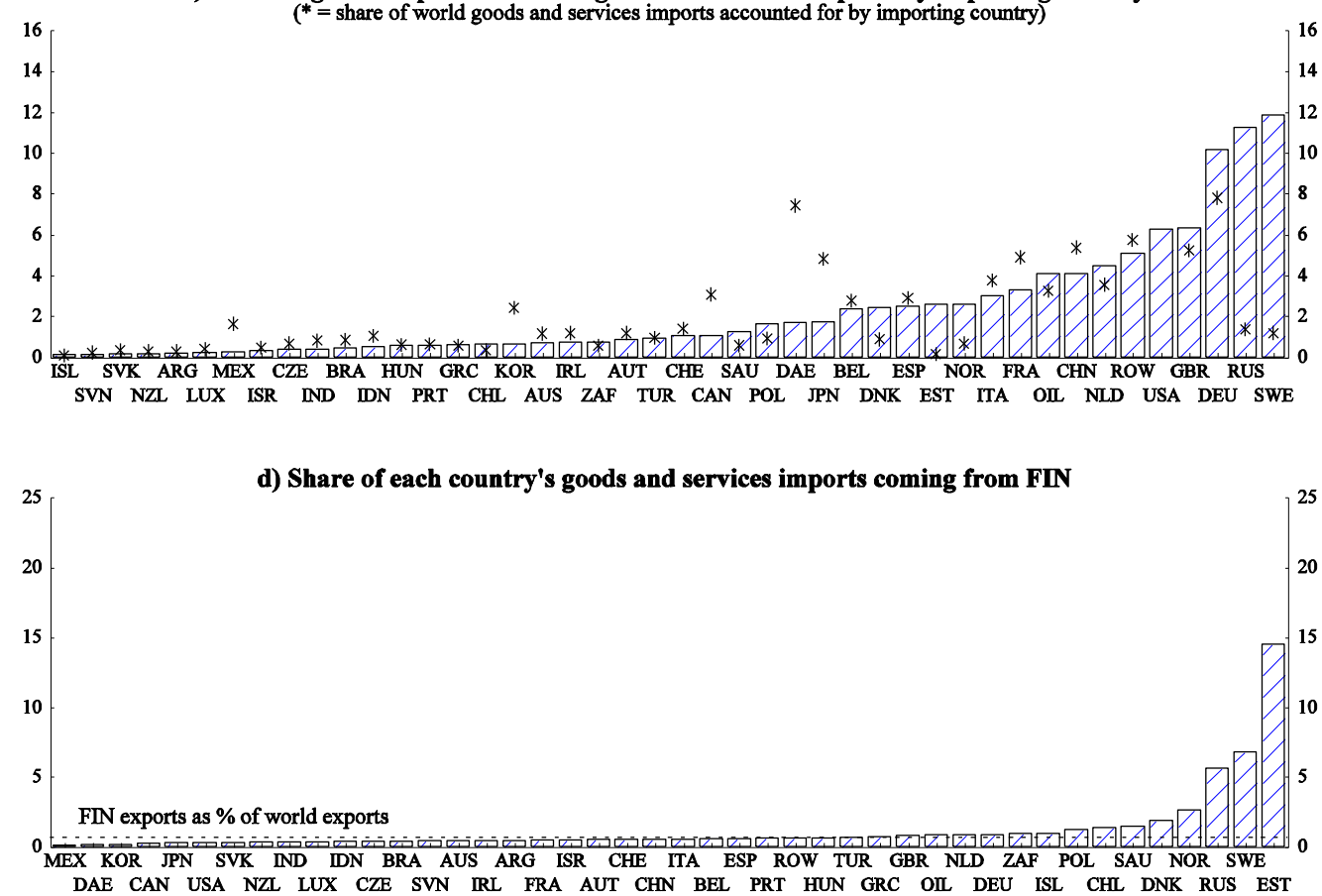
Figure 3.16. Geographical structure of goods and services trade of Greece (GRC)

a) Percentage decomposition of GRC goods and services imports by exporting country

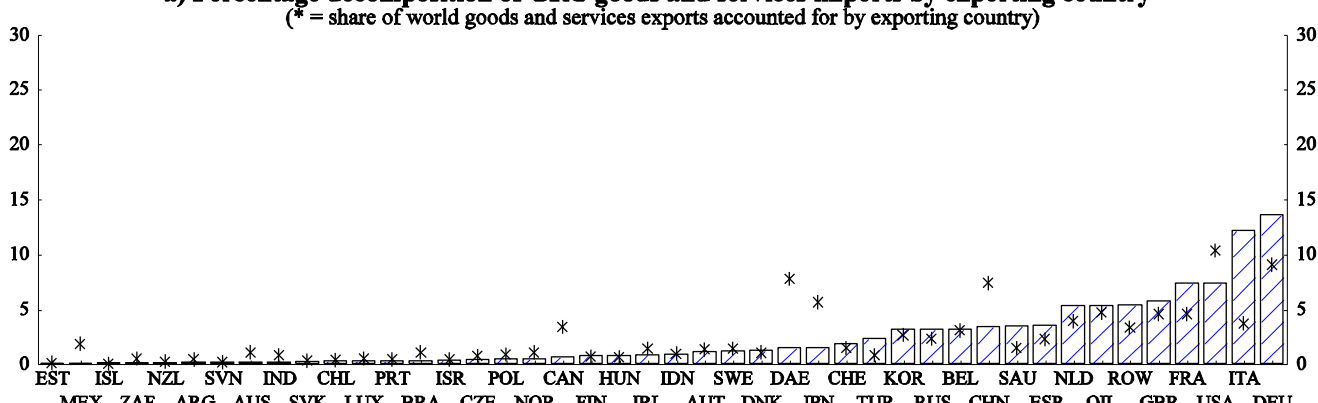

MEX ZAF ARG AUS SVK LUX BRA CZE NOR FIN IRL AUT DNK JPN TUR RUS CHN ESP OIL GBR USA DEU

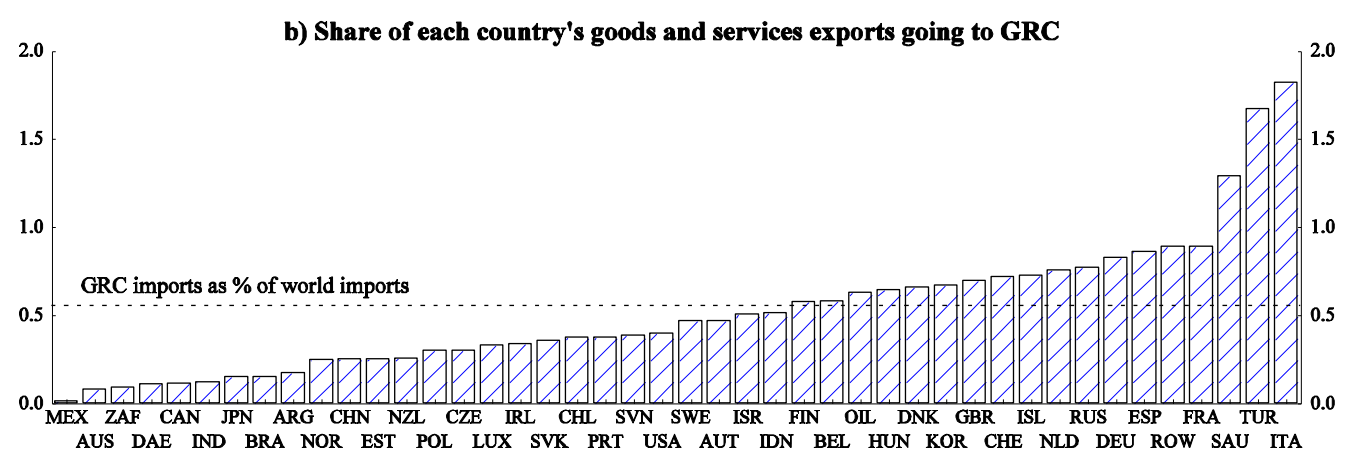

c) Percentage decomposition of GRC goods and services exports by importing country
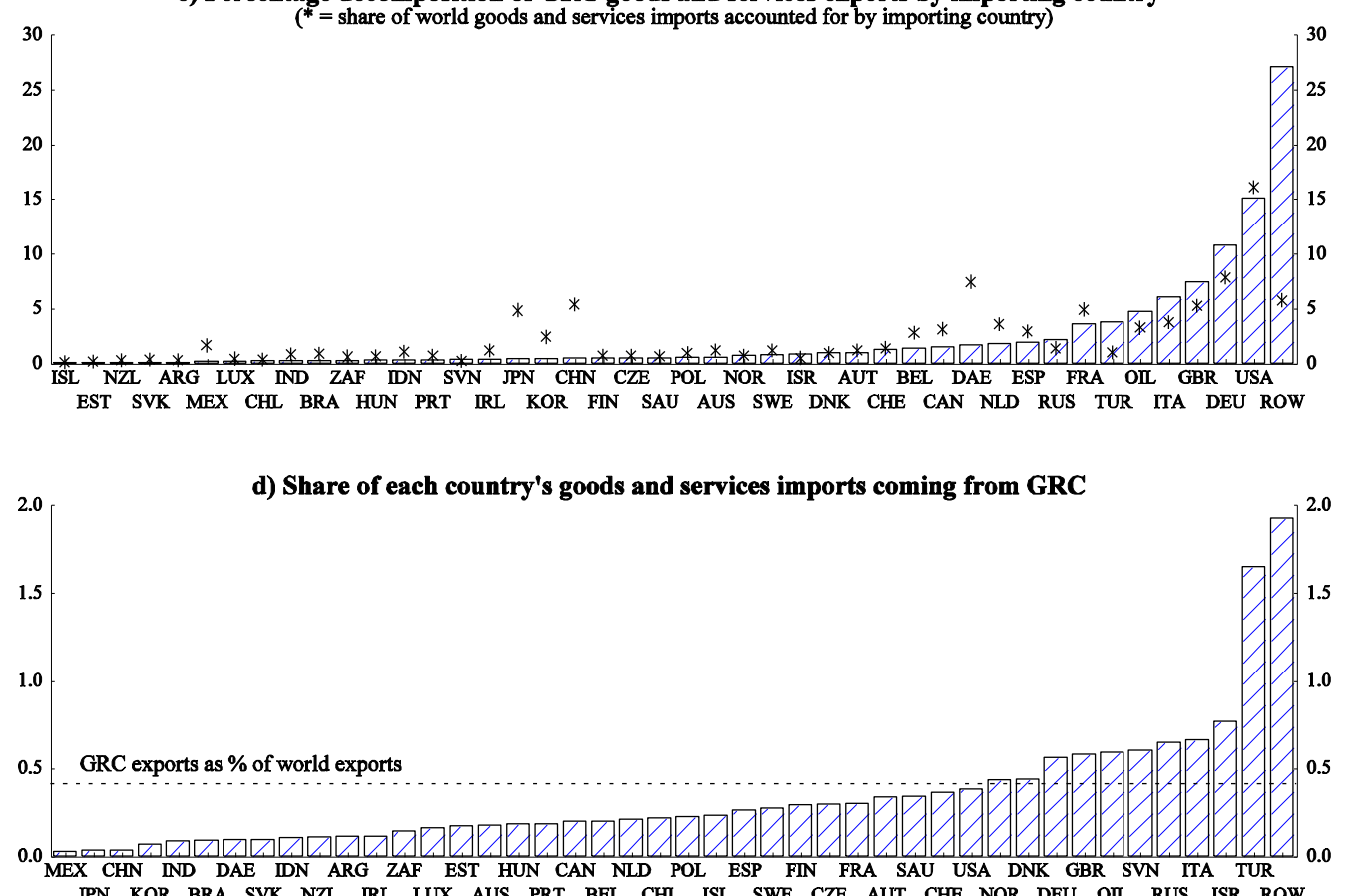
Figure 3.17. Geographical structure of goods and services trade of Hungary (HUN)

a) Percentage decomposition of HUN goods and services imports by exporting country

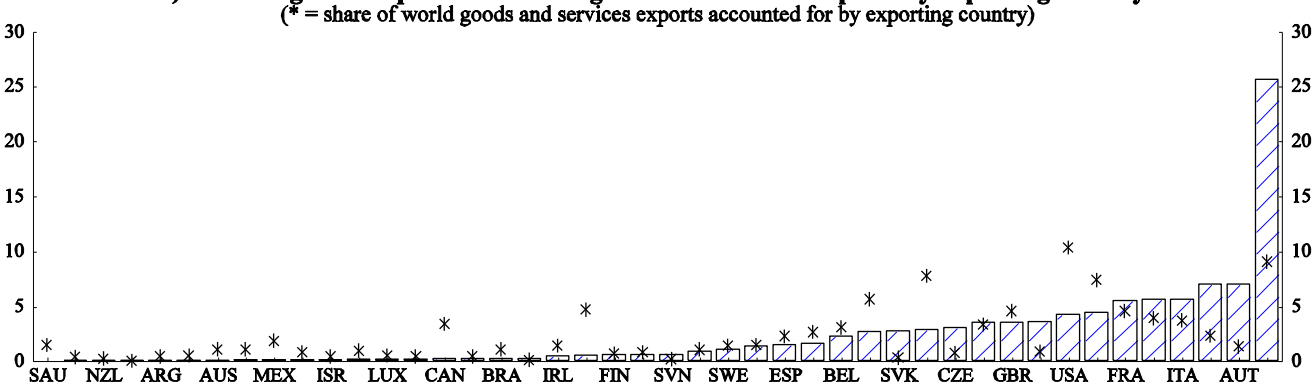

CHL ISL ZAF NOR IND IDN GRC PRT EST OIL TUR DNK CHE KOR JPN DAE ROW POL CHN NLD RUS DEU

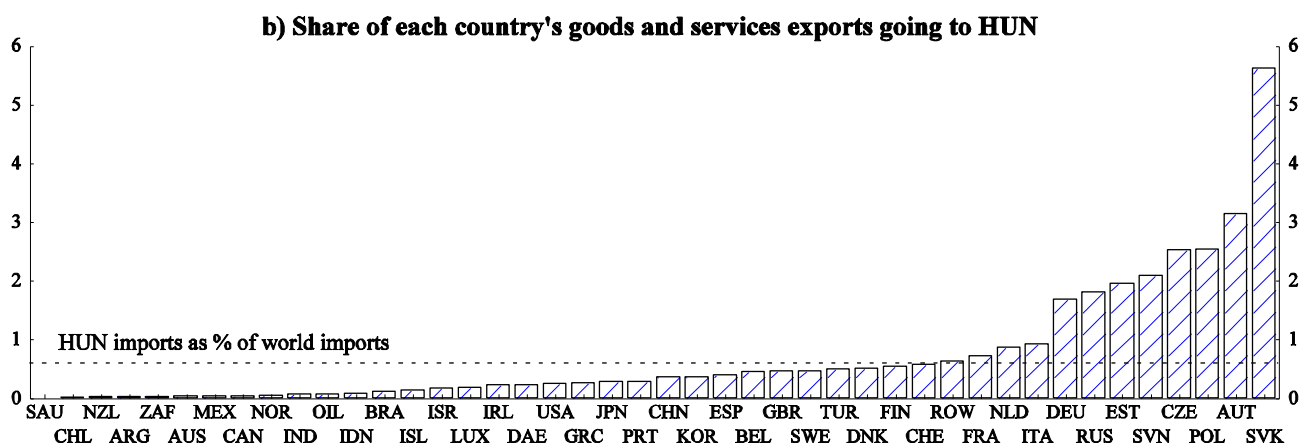

c) Percentage decomposition of HUN goods and services exports by importing country
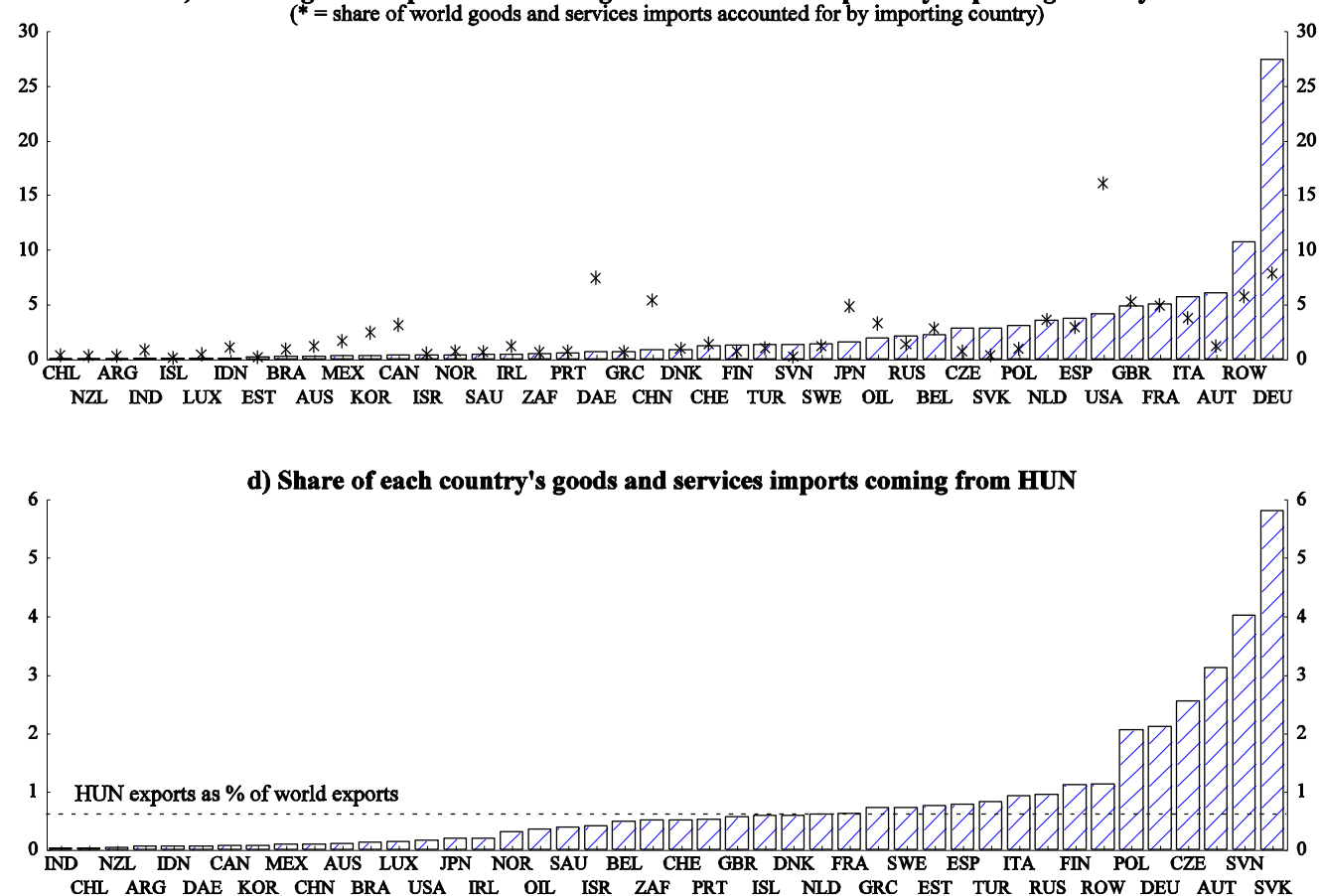
Figure 3.18. Geographical structure of goods and services trade of Iceland (ISL)

a) Percentage decomposition of ISL goods and services imports by exporting country

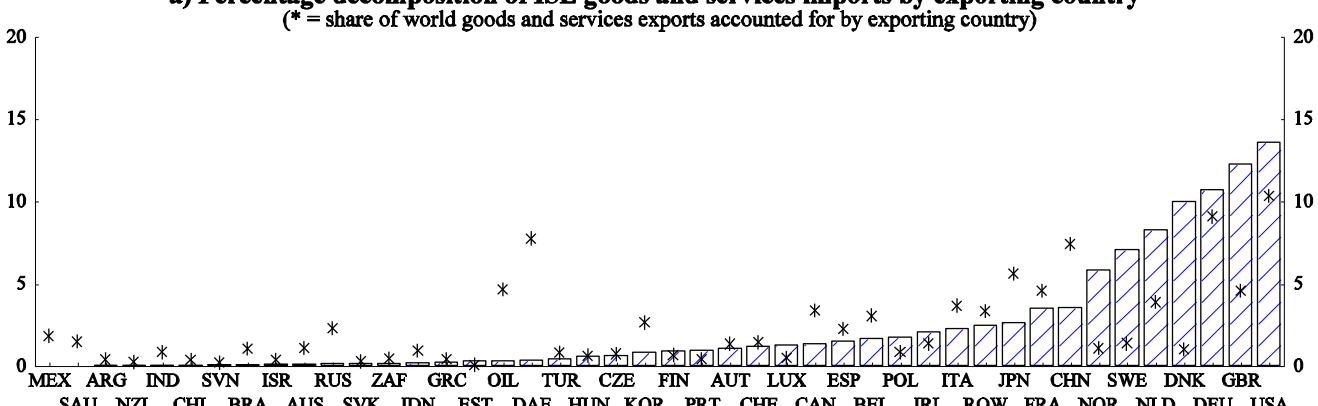

SAU NZL CHL BRA AUS SVK IDN EST DAE HUN KOR PRT CHE CAN BEL IRL ROW FRA NOR NLD DEU USA

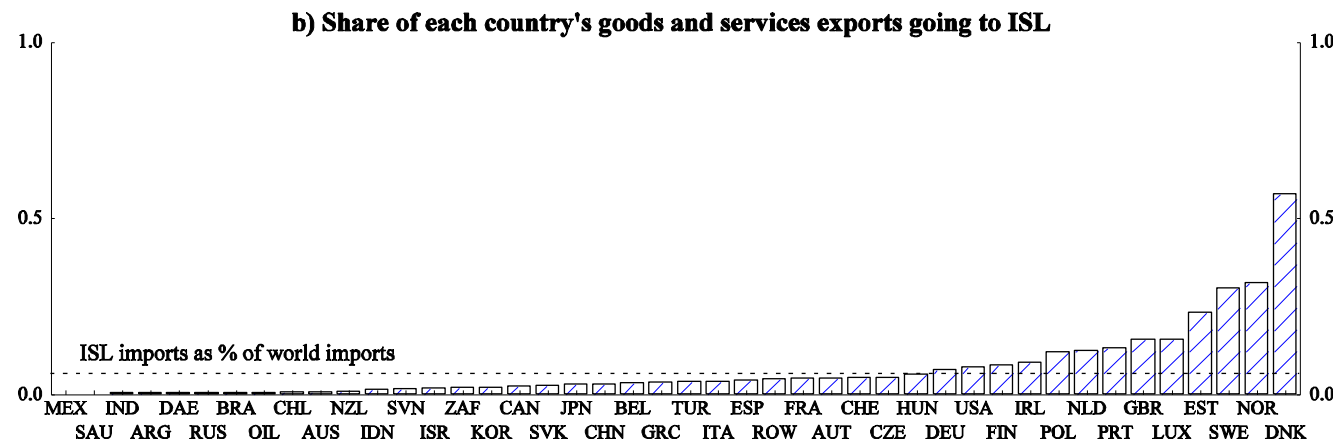

c) Percentage decomposition of ISL goods and services exports by importing country
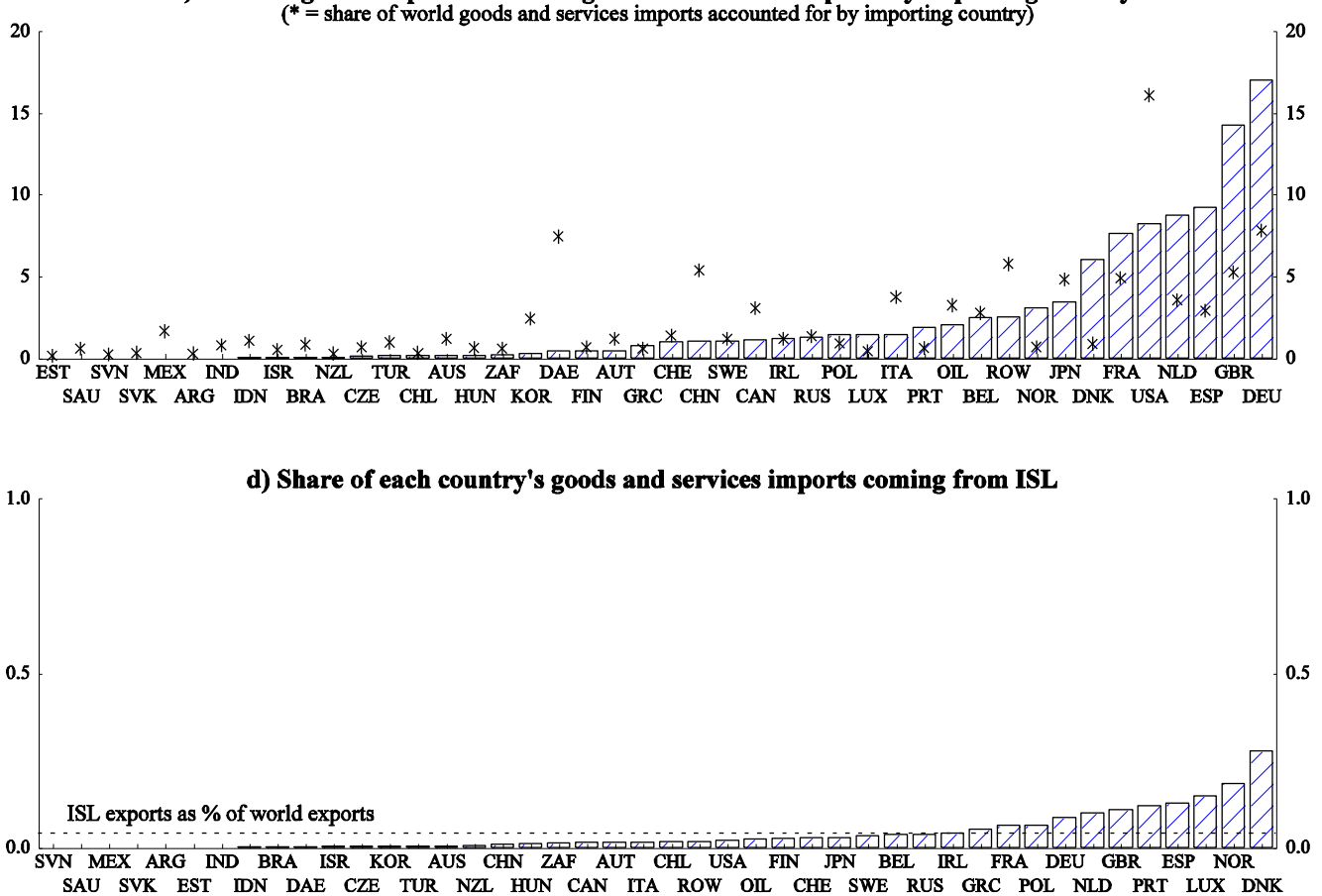
Figure 3.19. Geographical structure of goods and services trade of Ireland (IRL)

a) Percentage decomposition of IRL goods and services imports by exporting country $(*=$ share of world goods and services exports accounted for by exporting country)

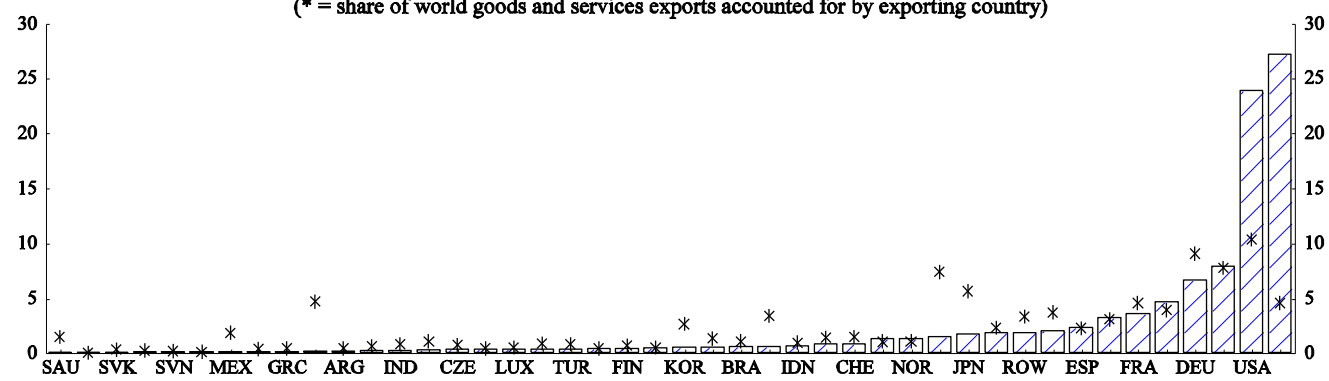

ISL NZL EST CHL OL HUN AUS PRT POL ISR ZAF AUT CAN SWE DNK CHN RUS ITA BEL NLD DAE GBR

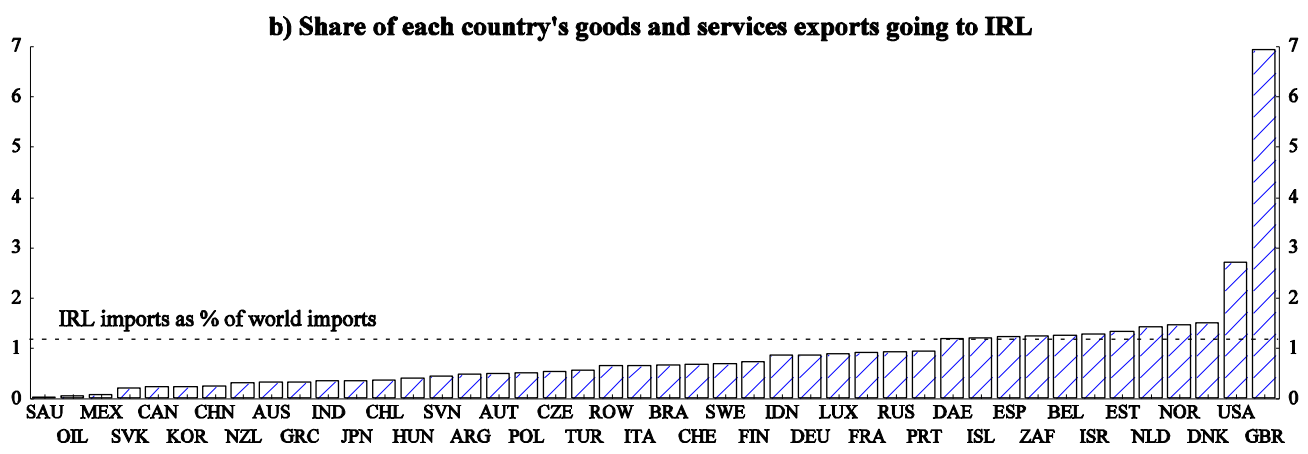

c) Percentage decomposition of IRL goods and services exports by importing country

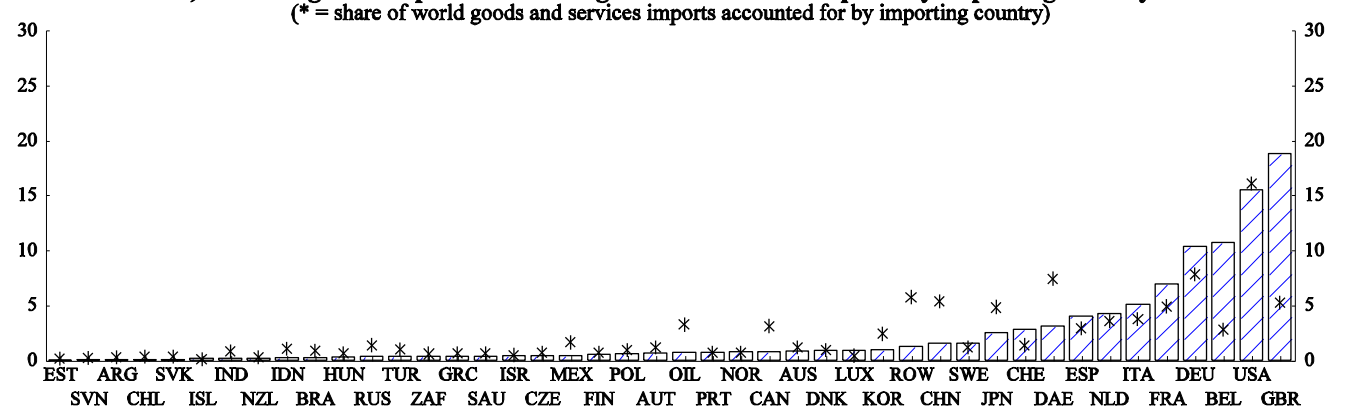

d) Share of each country's goods and services imports coming from IRI

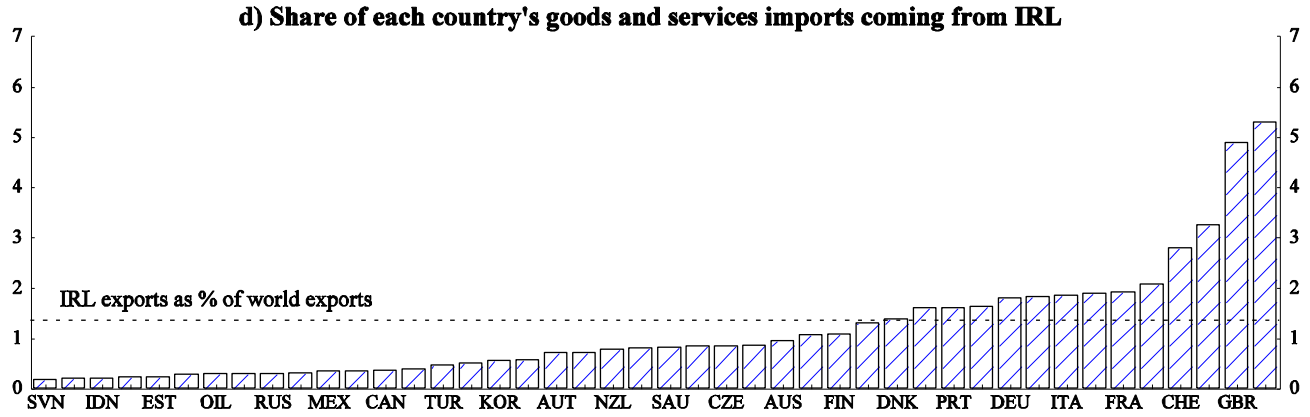

IND ARG CHL ROW BRA SVK CHN HUN DAE JPN ZAF GRC POL ISR USA NOR NLD SWE ESP ISL LUX BEL 
Figure 3.20. Geographical structure of goods and services trade of Korea (KOR)

a) Percentage decomposition of KOR goods and services imports by exporting country

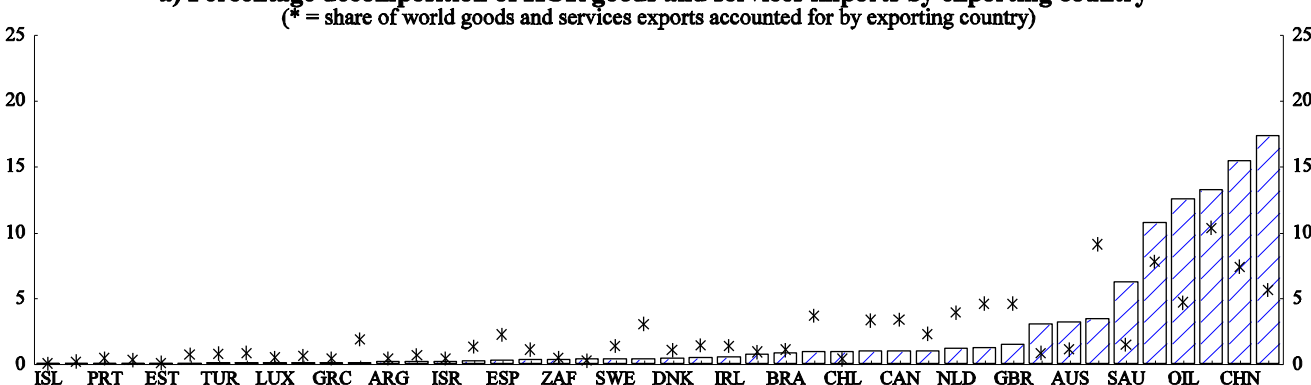
SVN SVK CZE POL HUN MEX FIN AUT NOR NZL BEL CHE IDN ITA ROW RUS FRA IND DEU DAE USA JPN

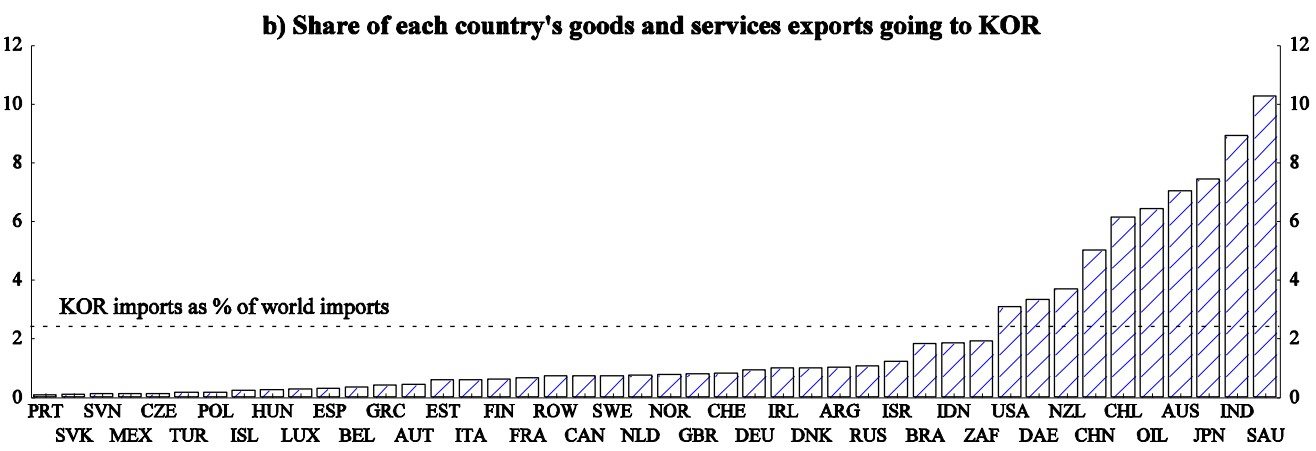

c) Percentage decomposition of KOR goods and services exports by importing country
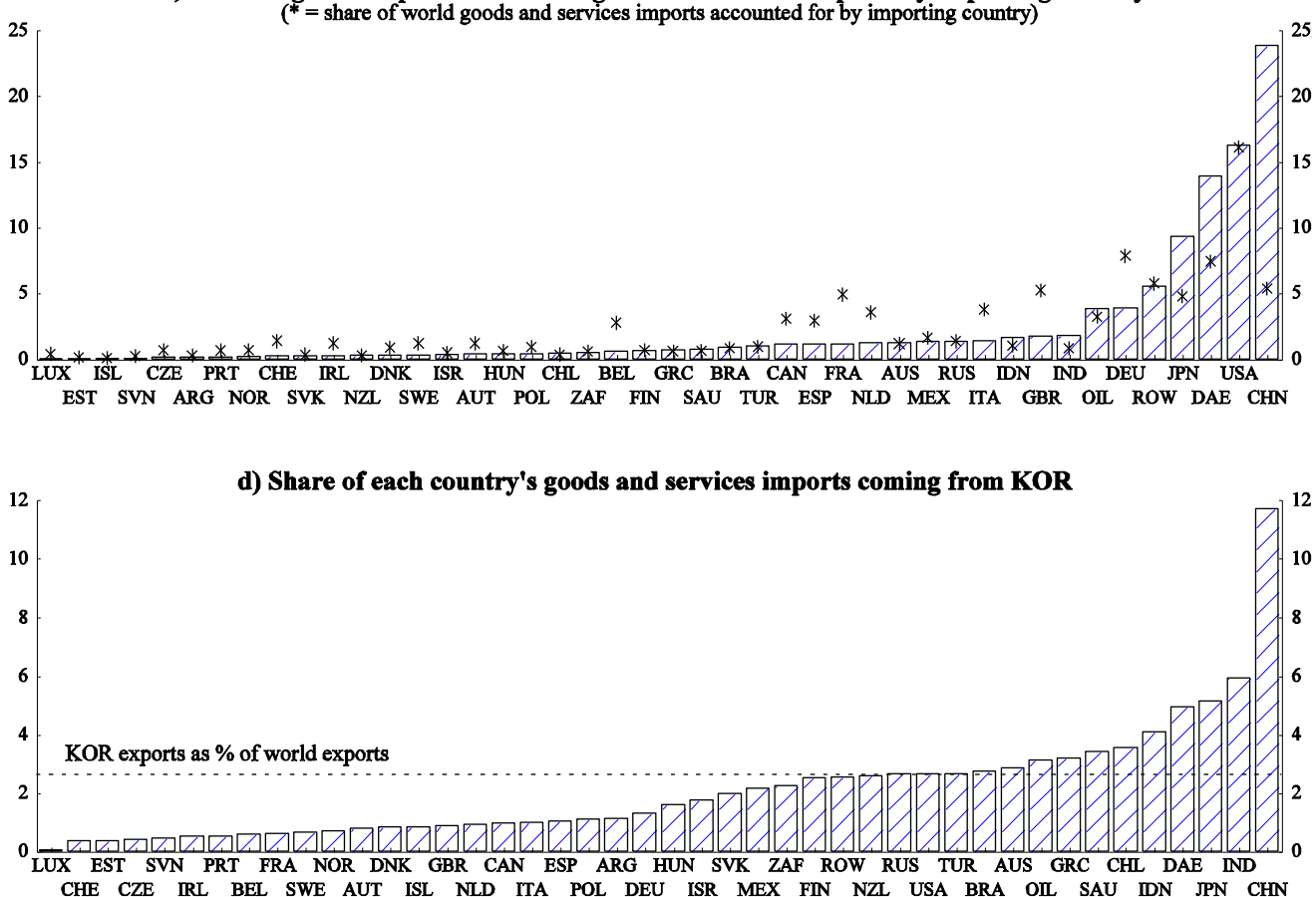
Figure 3.21. Geographical structure of goods and services trade of Luxembourg (LUX)

a) Percentage decomposition of LUX goods and services imports by exporting country $(*=$ share of world goods and services exports accounted for by exporting country)

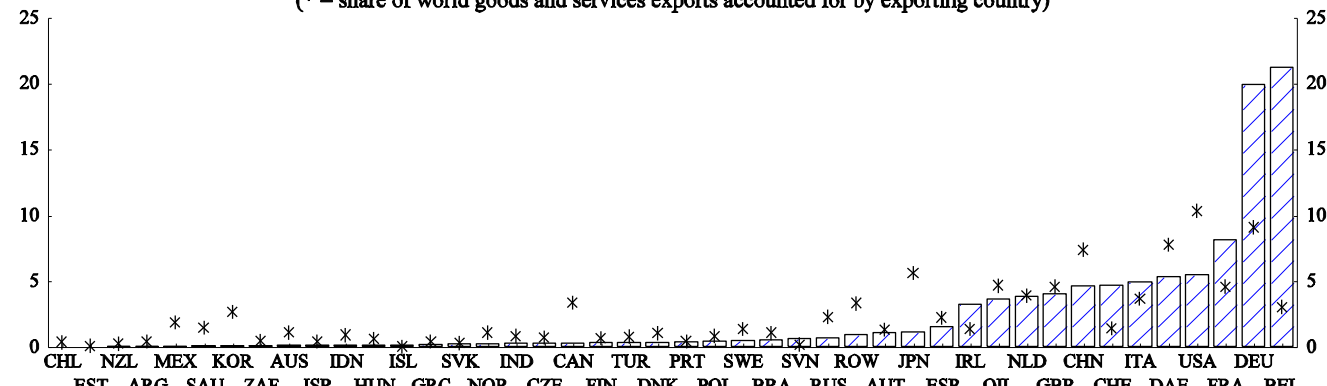

EST ARG SAU ZAF ISR HUN GRC NOR CZE FIN DNK POL BRA RUS AUT ESP OIL GBR CHE DAE FRA BEL

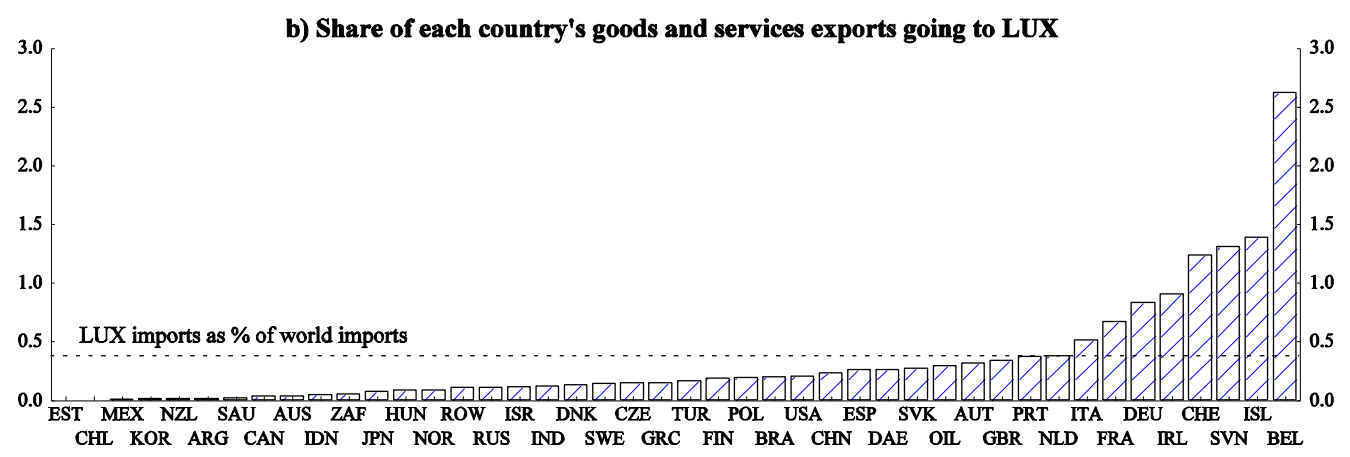

c) Percentage decomposition of LUX goods and services exports by importing country
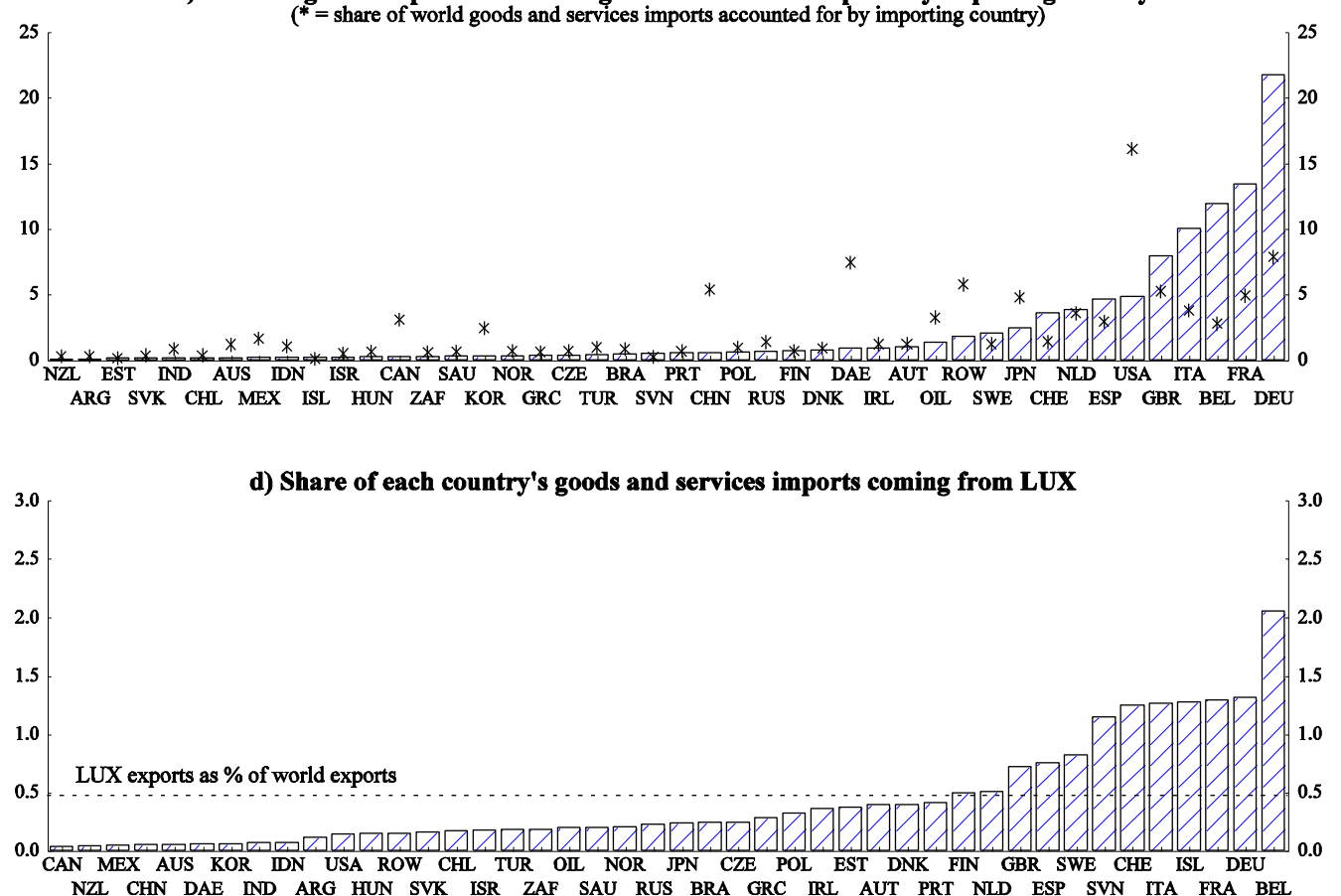
Figure 3.22. Geographical structure of goods and services trade of Mexico (MEX)

a) Percentage decomposition of MEX goods and services imports by exporting country
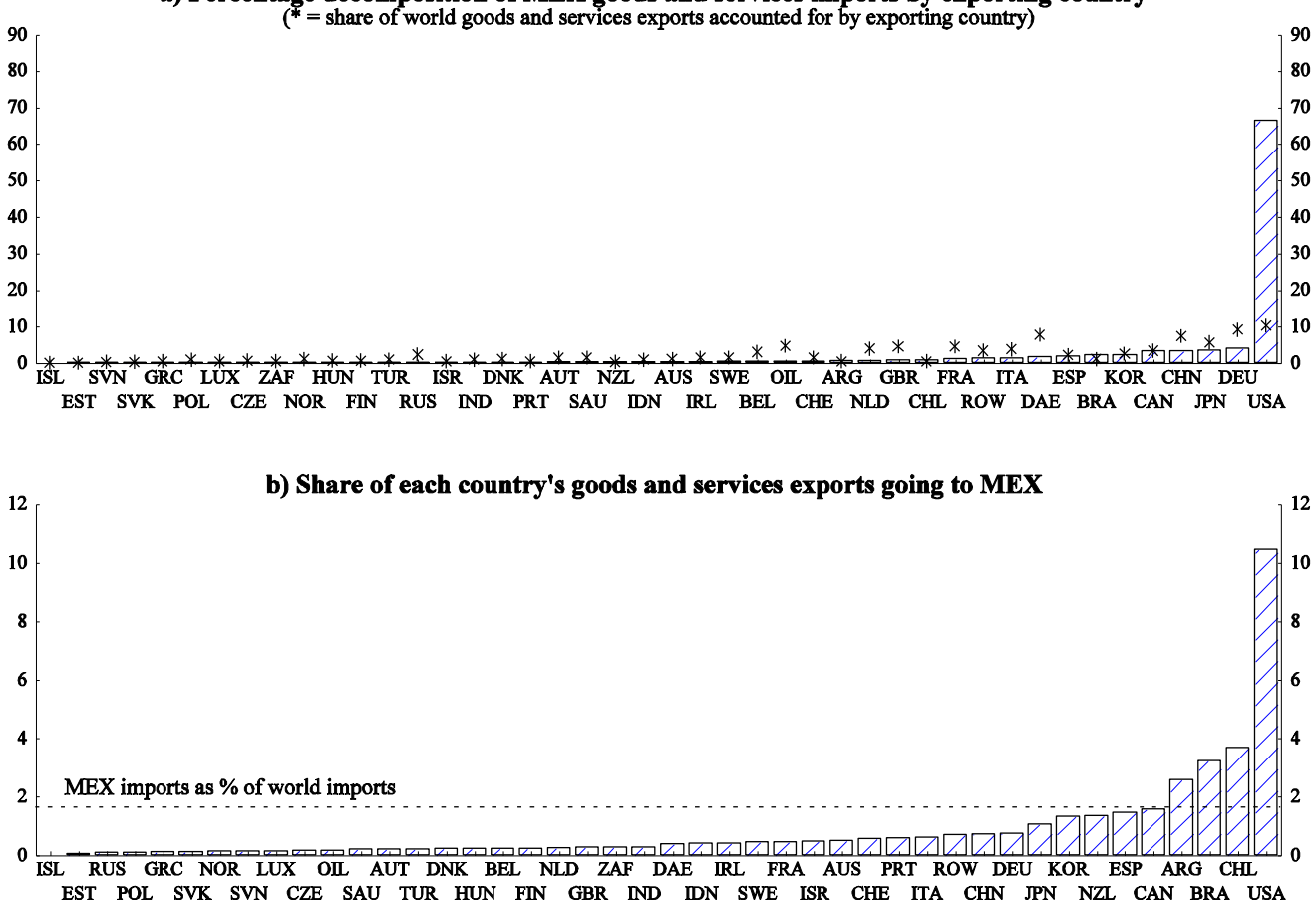

c) Percentage decomposition of MEX goods and services exports by importing country
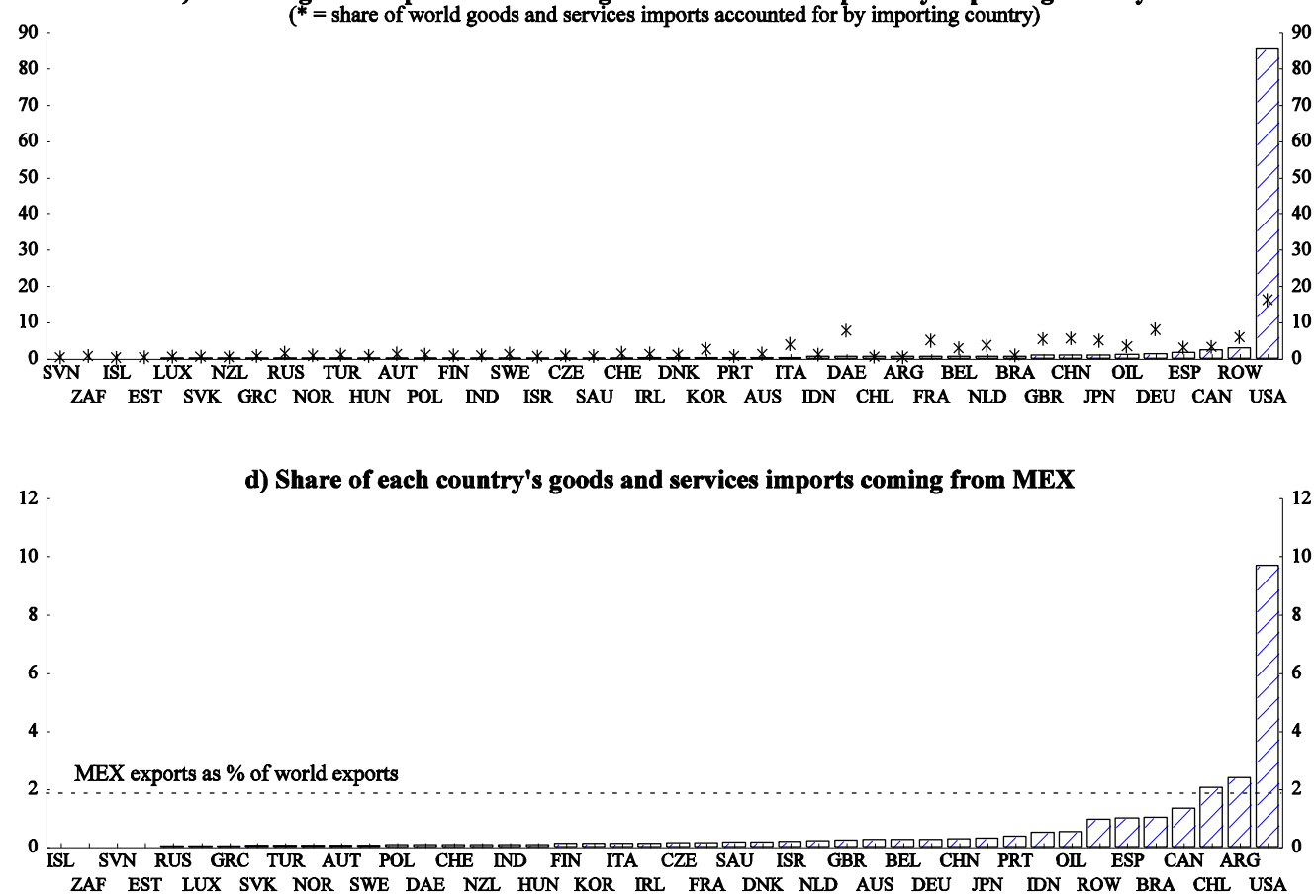
Figure 3.23. Geographical structure of goods and services trade of the Netherlands (NLD)

a) Percentage decomposition of NLD goods and services imports by exporting country

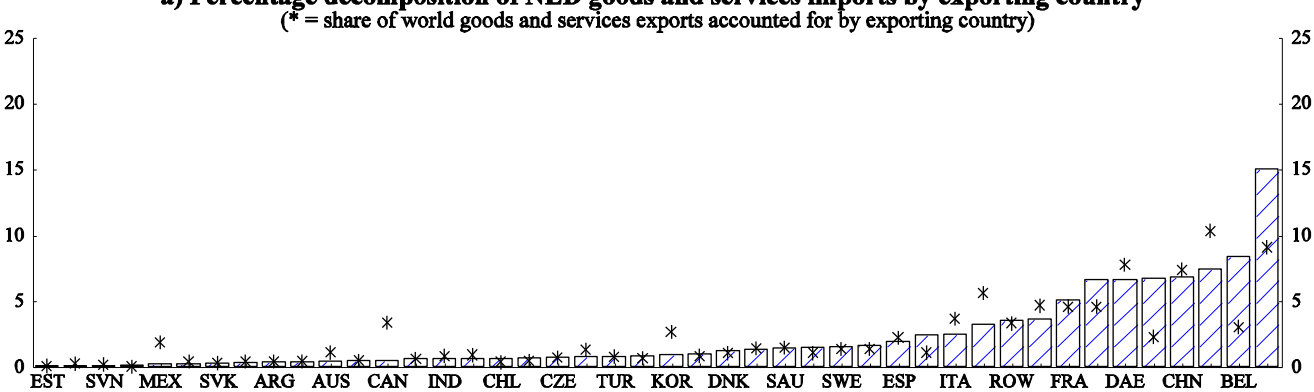
NZL ISL GRC ISR PRT LUX HUN IDN ZAF AUT FIN POL CHE BRA IRL NOR JPN OL GBR RUS USA DEU

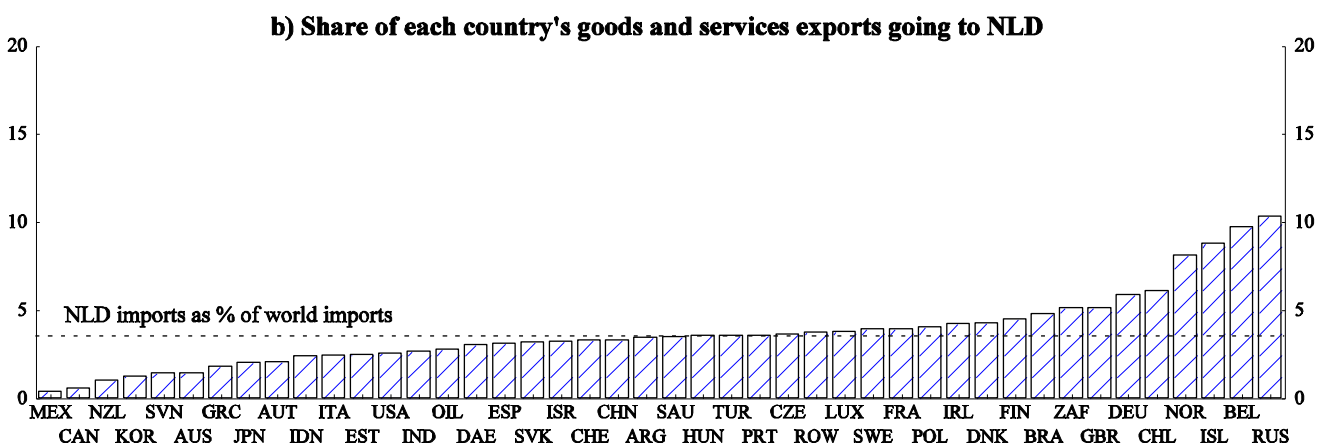

c) Percentage decomposition of NLD goods and services exports by importing country
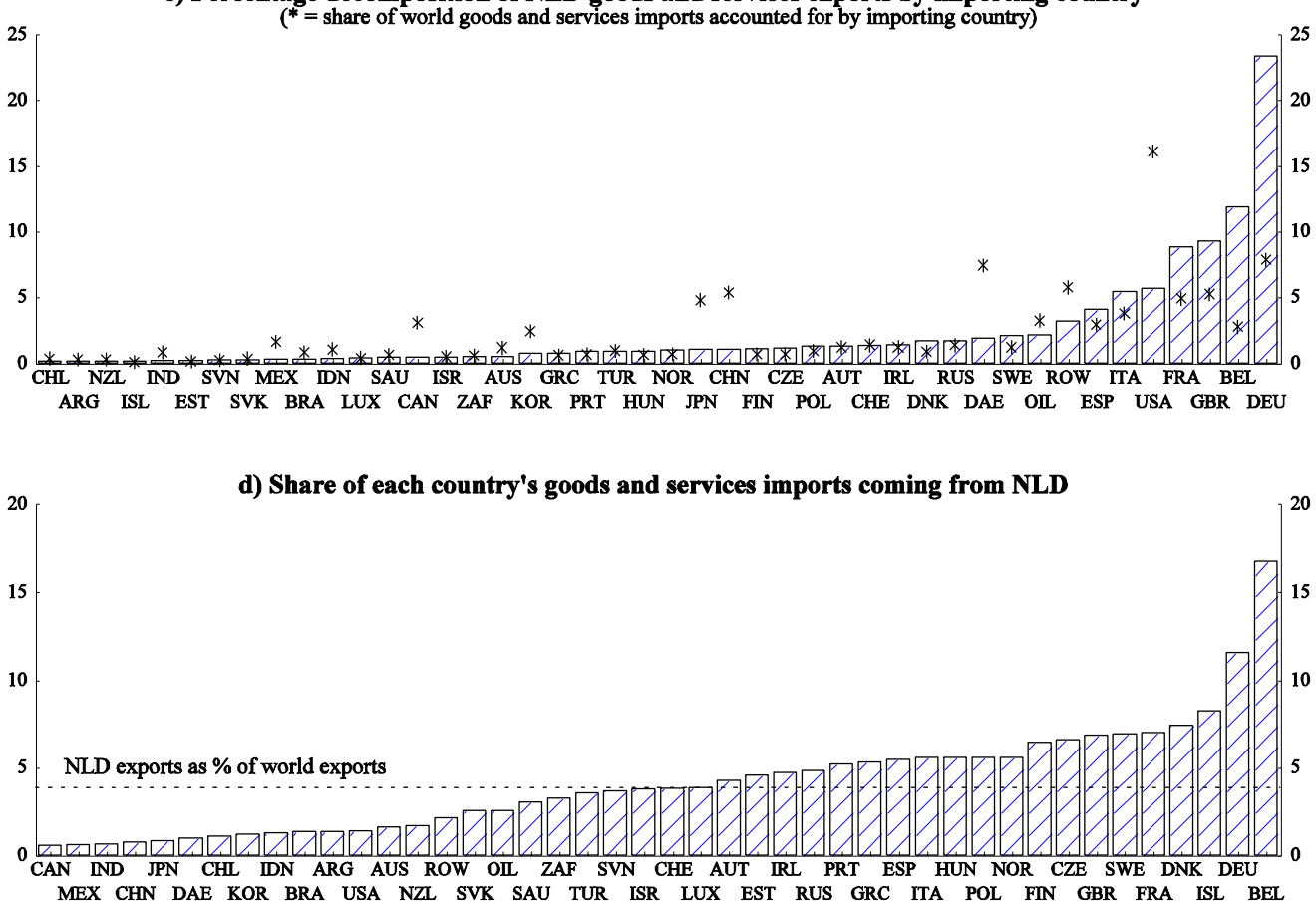
Figure 3.24. Geographical structure of goods and services trade of New Zealand (NZL)

a) Percentage decomposition of NZL goods and services imports by exporting country $(*$ share of world goods and services exports accounted for by exporting country)

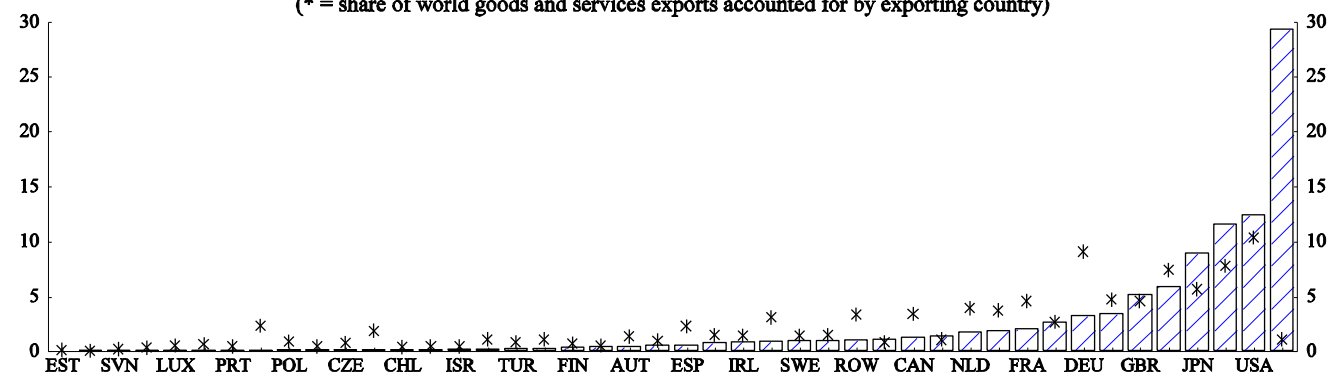

ISL SVK HUN RUS ARG MEX GRC NOR BRA ZAF IDN CHE BEL SAU IND DNK ITA KOR OIL CHN DAE AUS

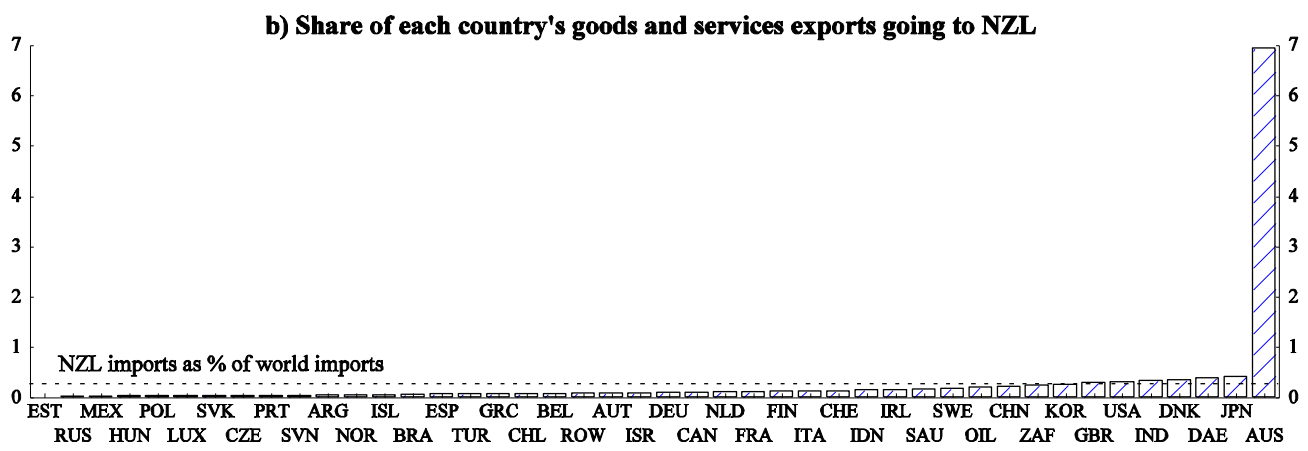

c) Percentage decomposition of NZL goods and services exports by importing country
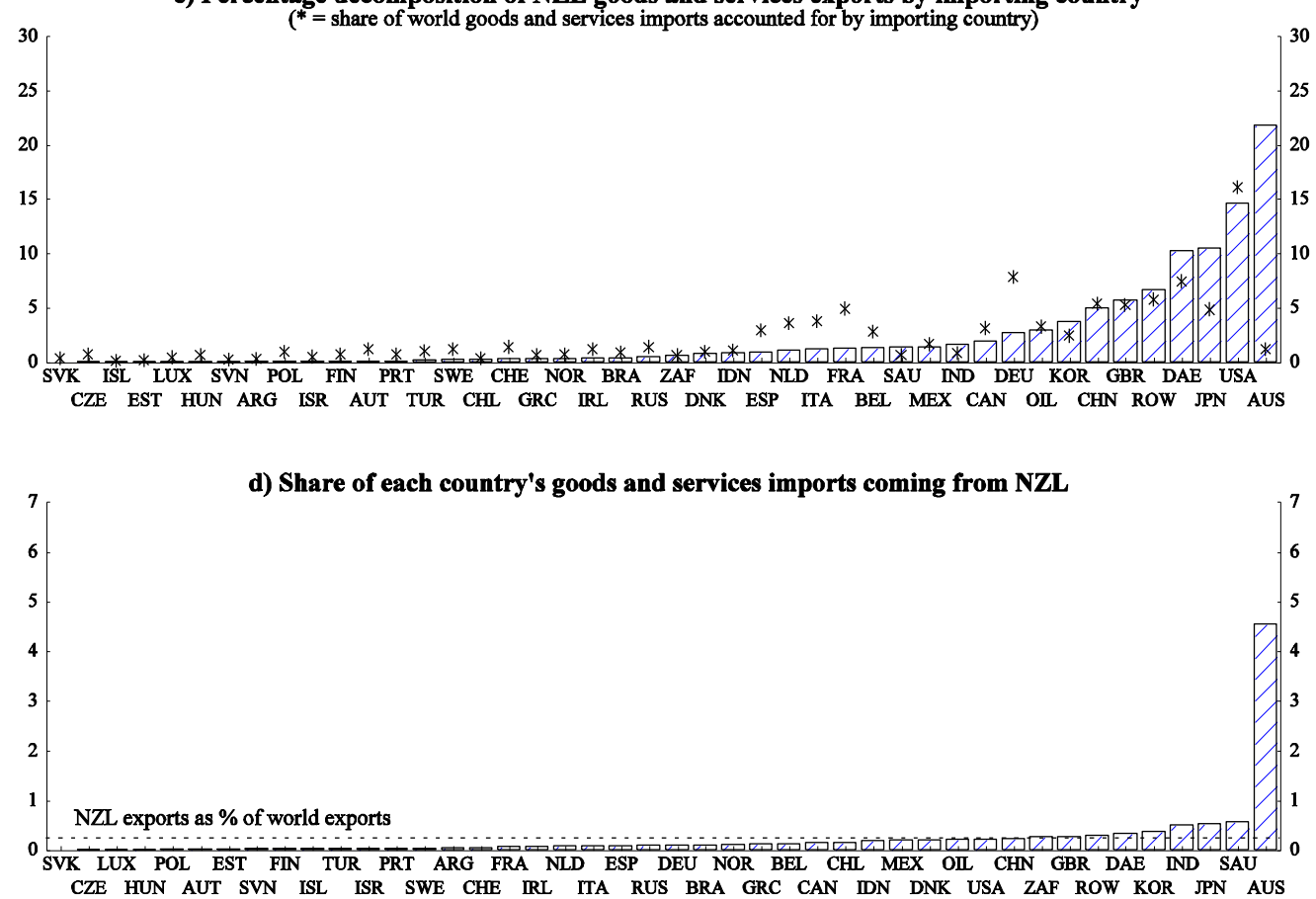
Figure 3.25. Geographical structure of goods and services trade of Norway (NOR)

a) Percentage decomposition of NOR goods and services imports by exporting country

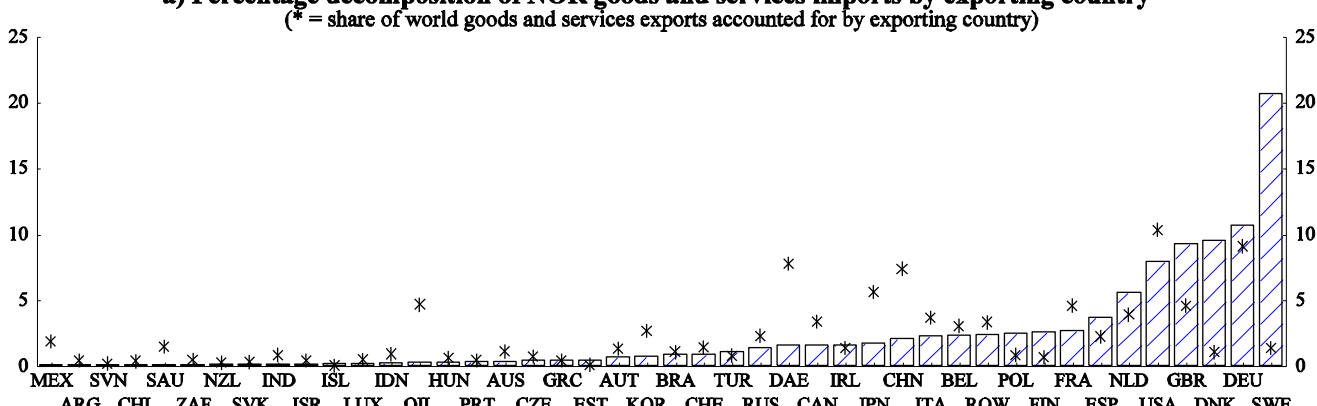

ARG CHL ZAF SVK ISR LUX OIL PRT CZE EST KOR CHE RUS CAN JPN ITA ROW FIN ESP USA DNK SWE

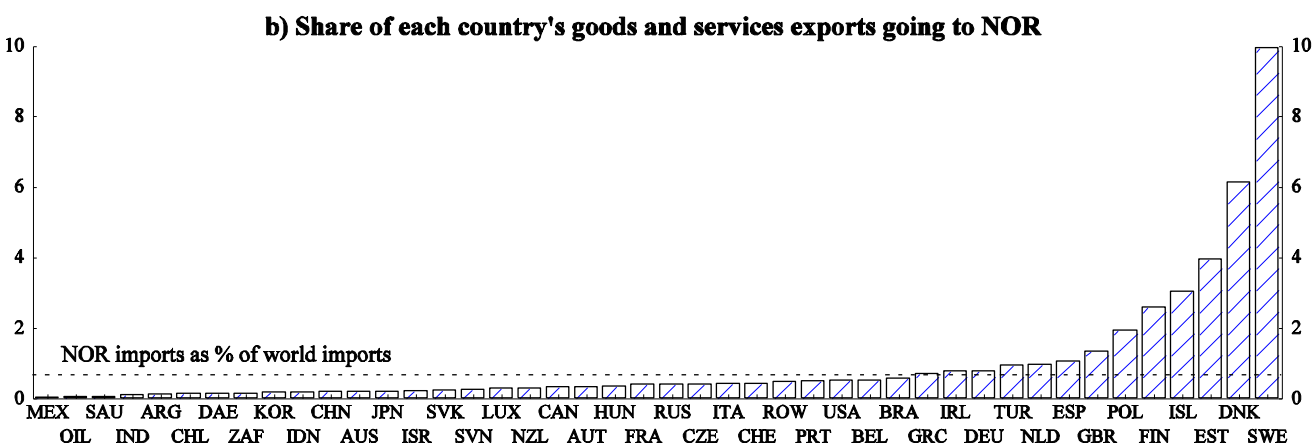

c) Percentage decomposition of NOR goods and services exports by importing country
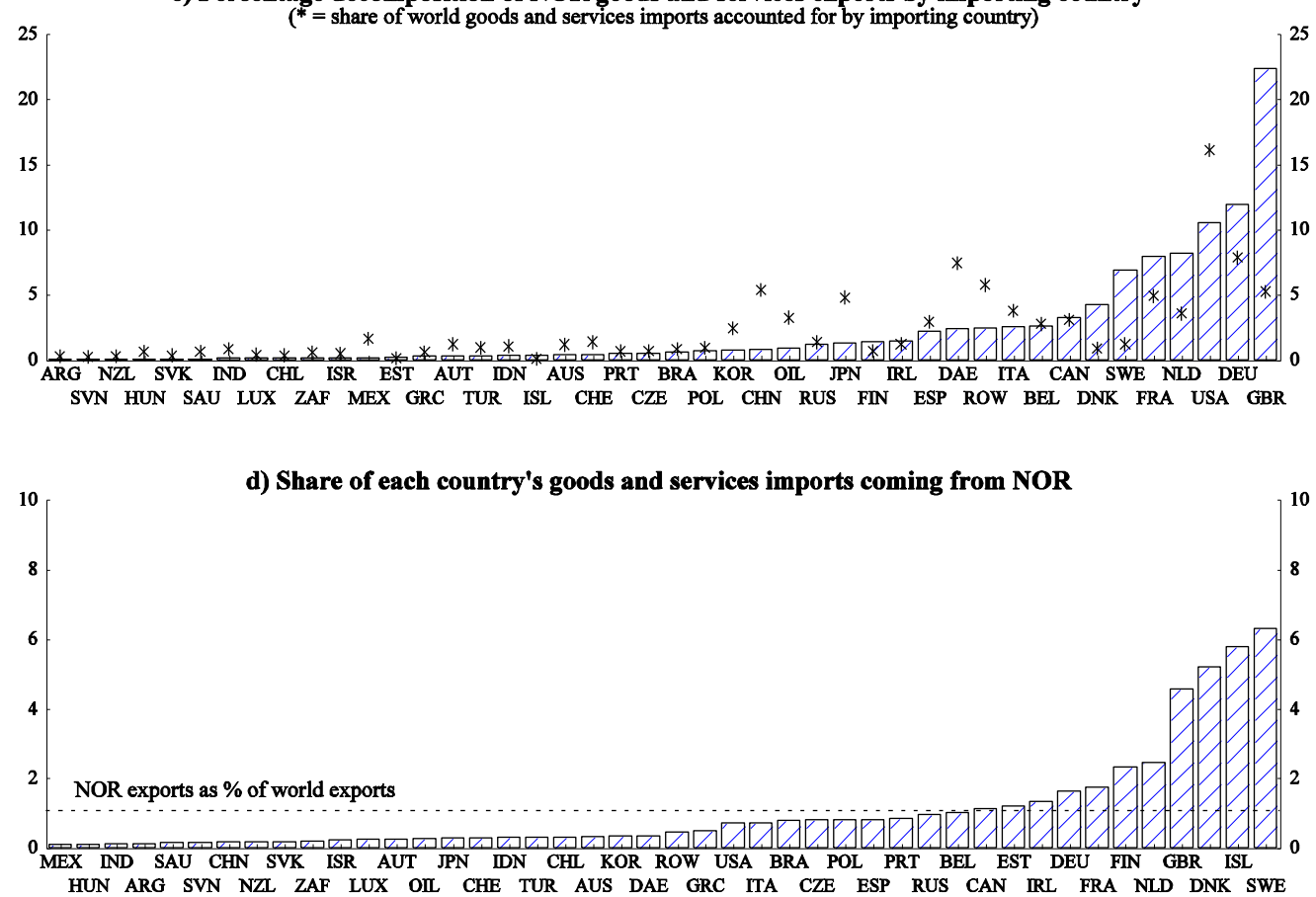
Figure 3.26. Geographical structure of goods and services trade of Poland (POL)

a) Percentage decomposition of POL goods and services imports by exporting country

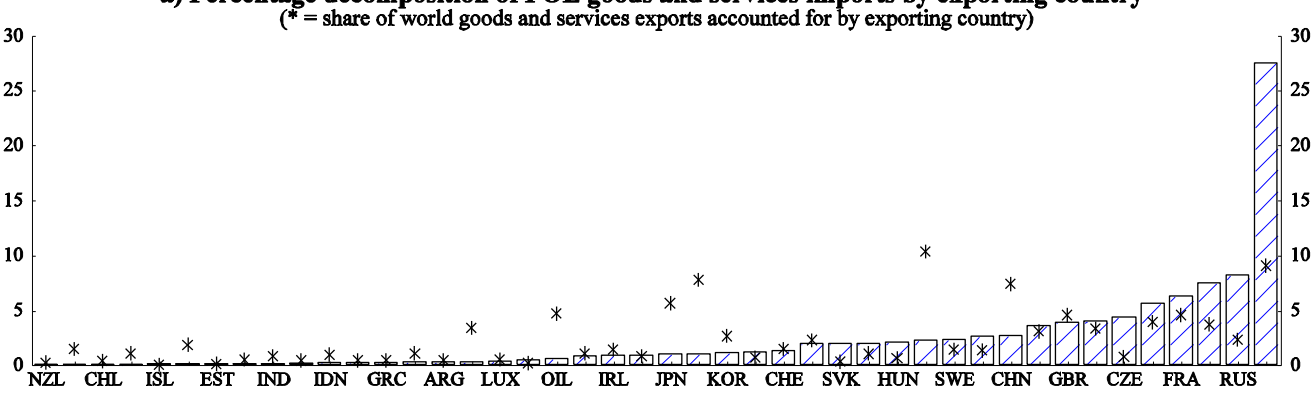
SAU AUS MEX ZAF ISR PRT BRA CAN SVN NOR TUR DAE FIN ESP DNK USA AUT BEL ROW NLD ITA DEU

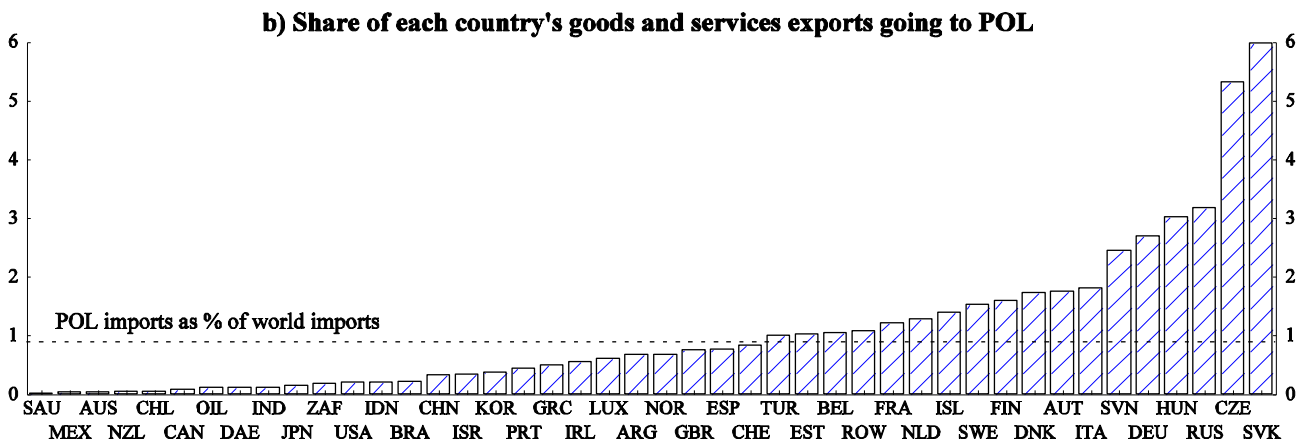

c) Percentage decomposition of POL goods and services exports by importing country
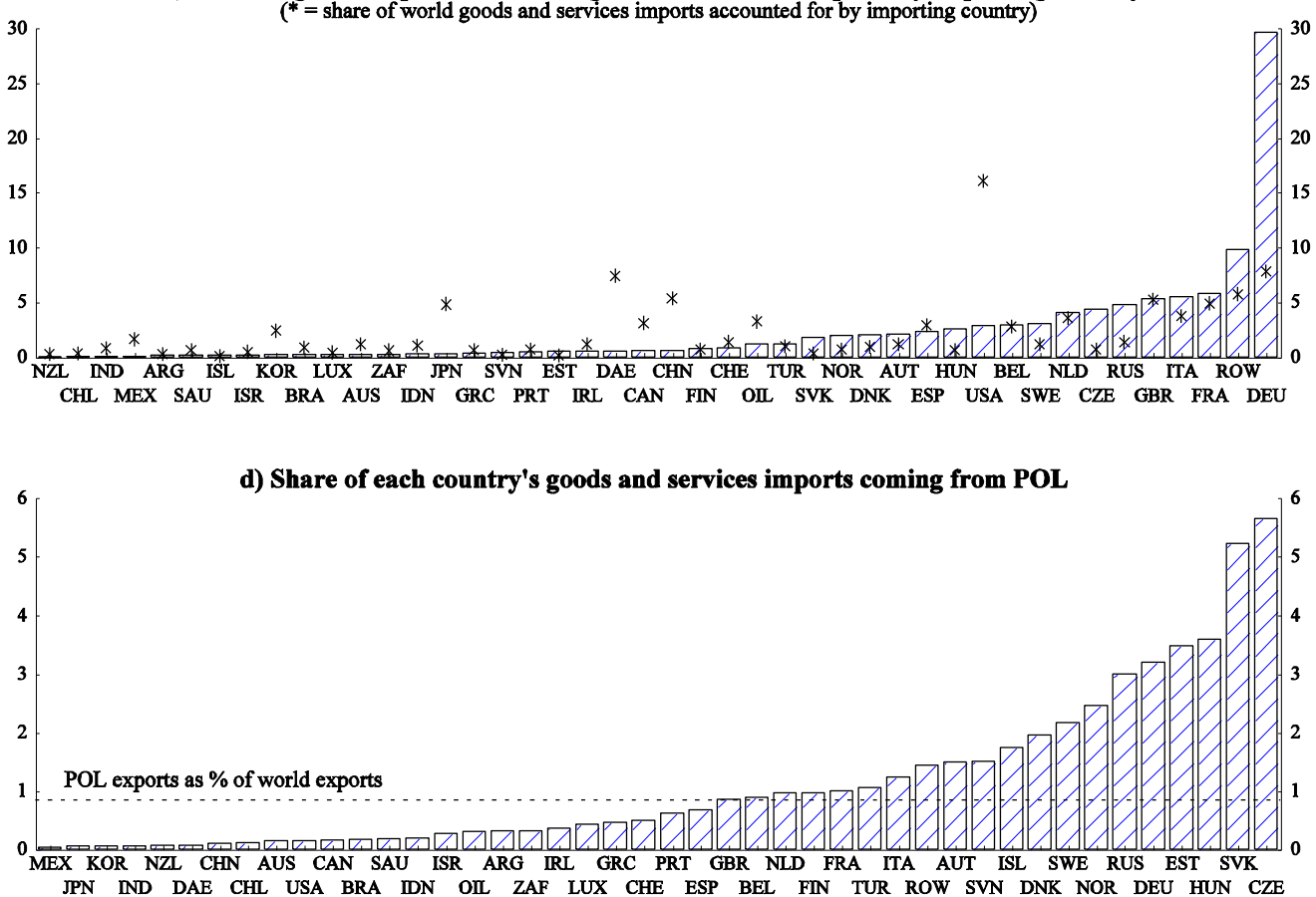
Figure 3.27. Geographical structure of goods and services trade of Portugal (PRT)

a) Percentage decomposition of PRT goods and services imports by exporting country
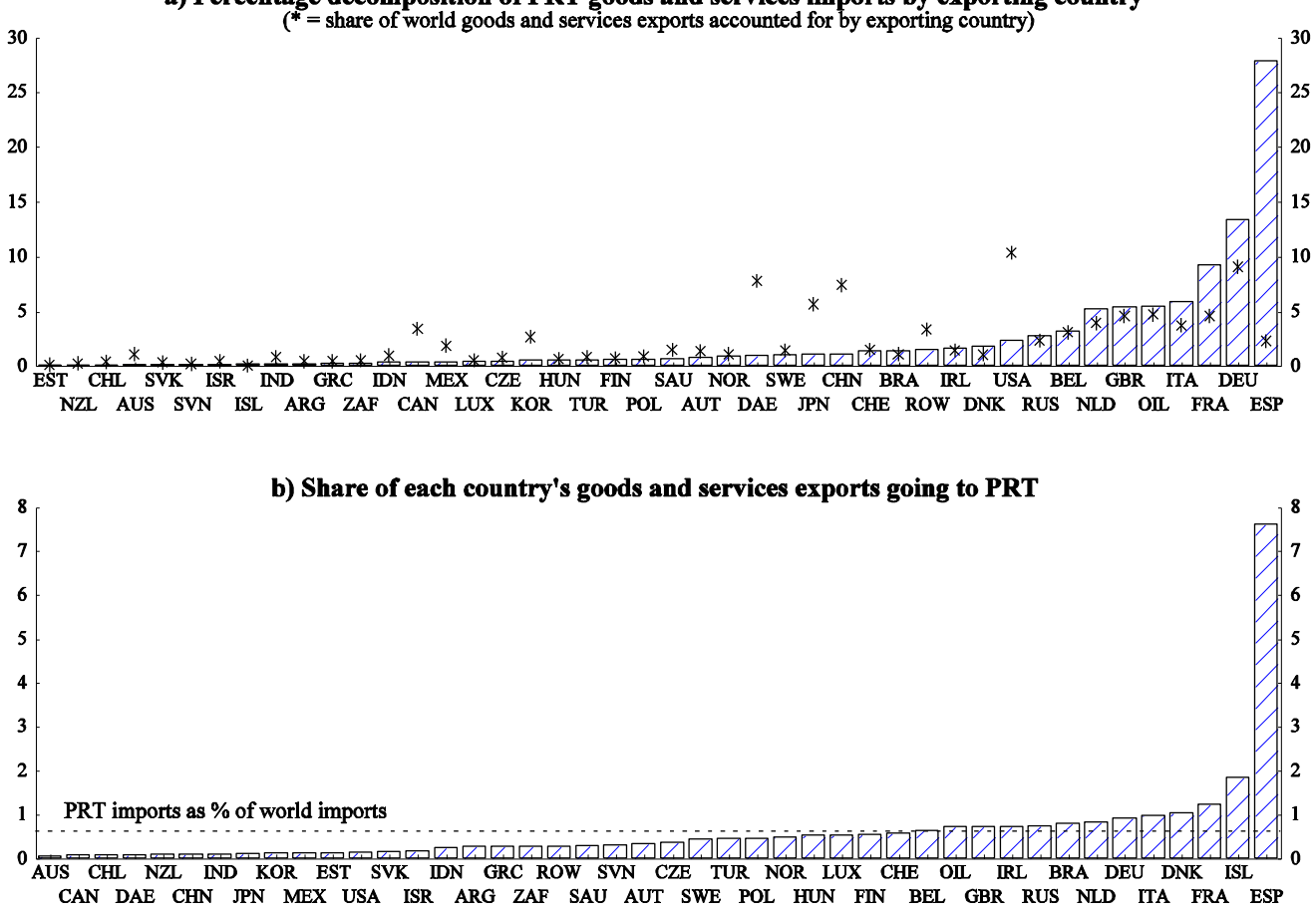

c) Percentage decomposition of PRT goods and services exports by importing country
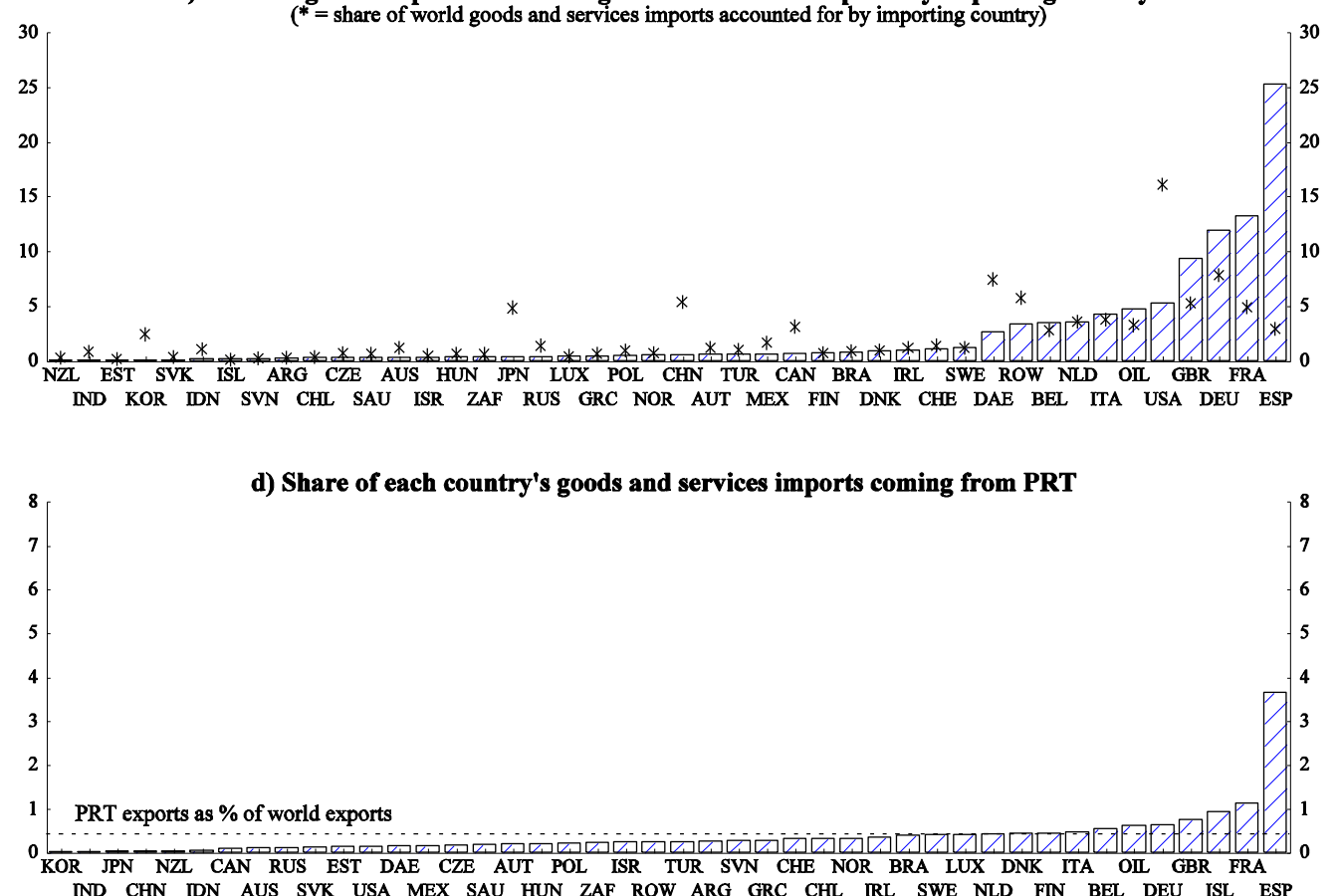
Figure 3.28. Geographical structure of goods and services trade of Slovak Republic (SVK)

a) Percentage decomposition of SVK goods and services imports by exporting country
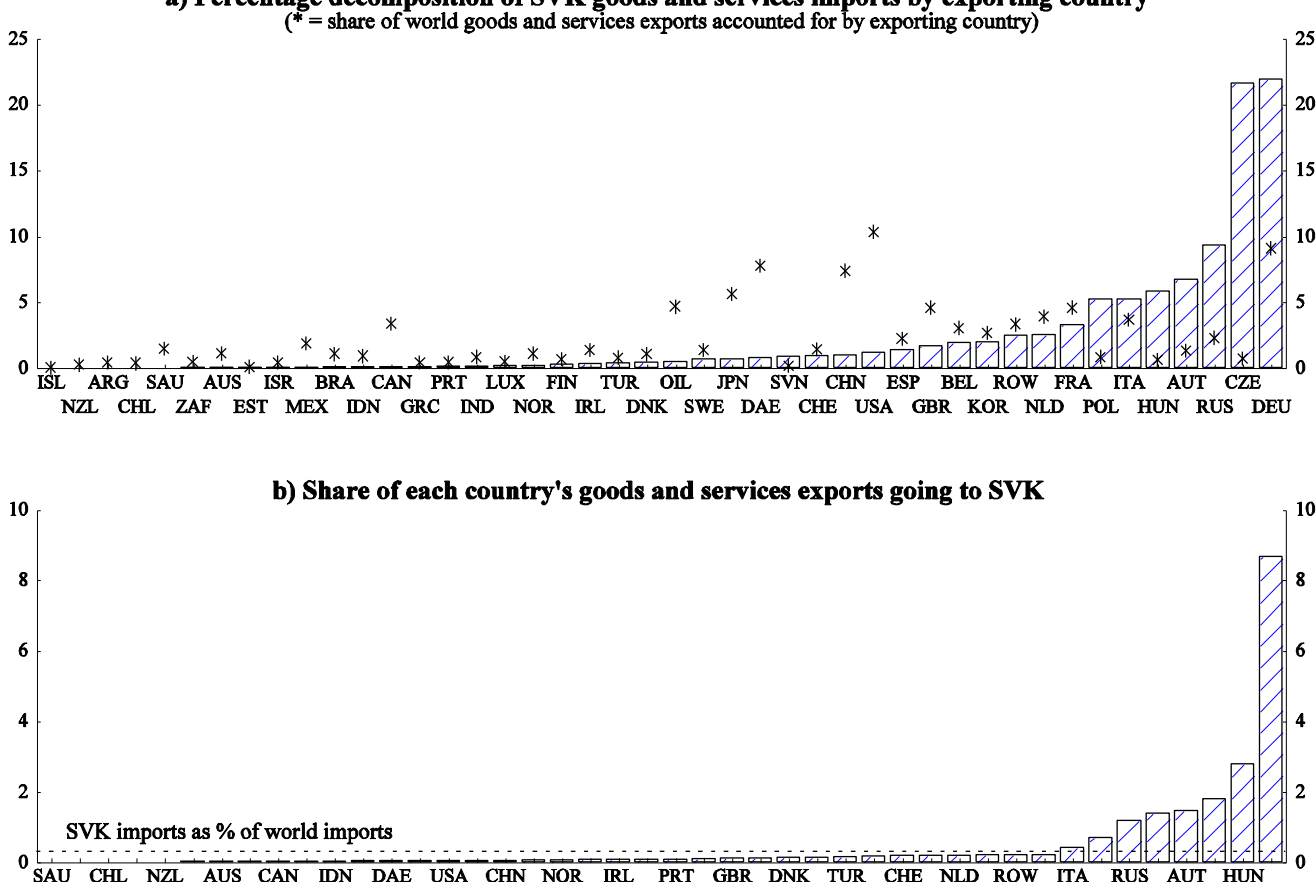

ISL ARG ZAF MEX BRA ISR OIL JPN IND GRC EST LUX FIN SWE ESP BEL FRA KOR DEU SVN POL CZE

c) Percentage decomposition of SVK goods and services exports by importing country
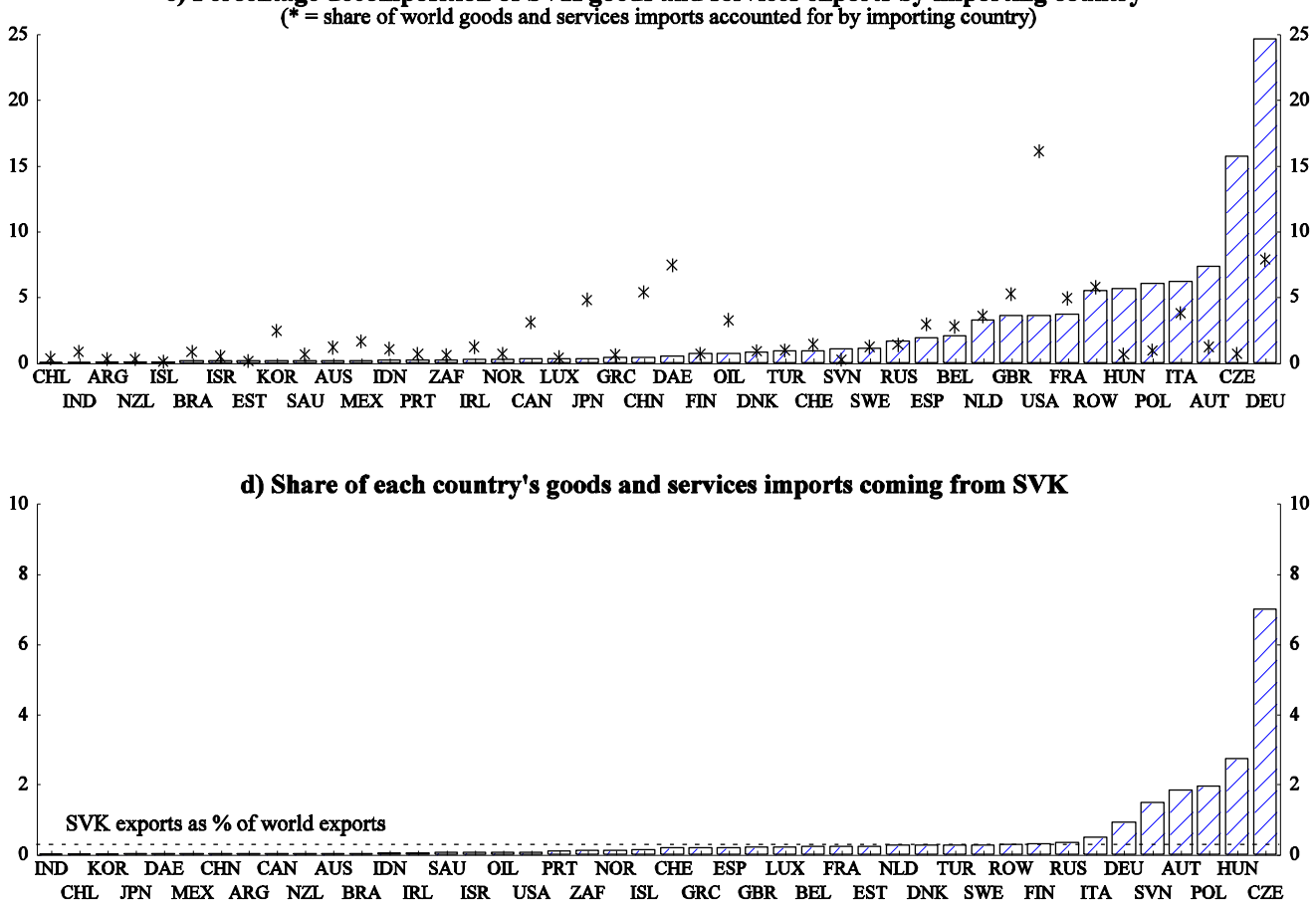
Figure 3.29. Geographical structure of goods and services trade of Slovenia (SVN)

a) Percentage decomposition of SVN goods and services imports by exporting country

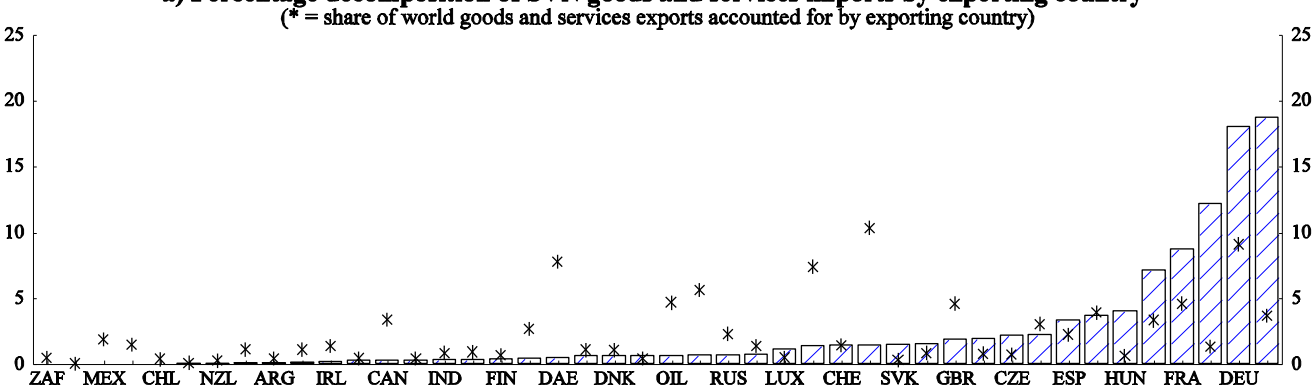

ISL SAU EST AUS NOR PRT ISR IDN KOR BRA GRC JPN SWE CHN USA POL TUR BEL NLD ROW AUT ITA

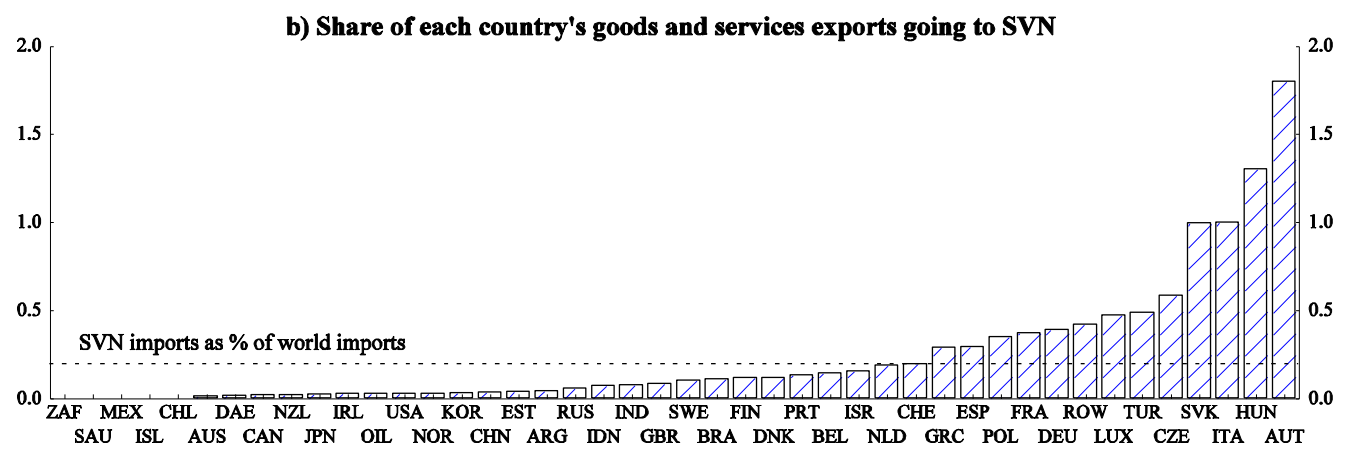

c) Percentage decomposition of SVN goods and services exports by importing country
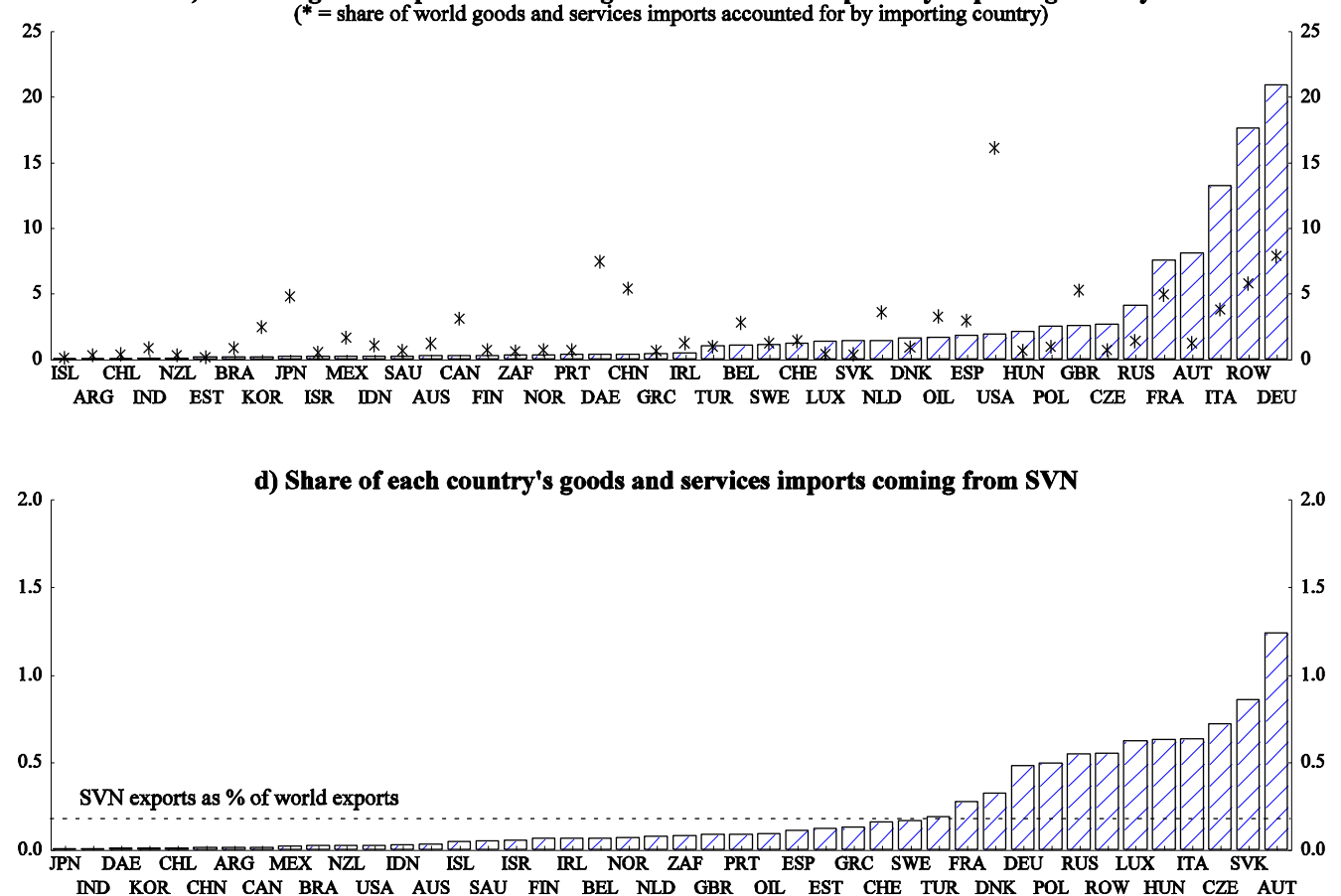
Figure 3.30. Geographical structure of goods and services trade of Spain (ESP)

a) Percentage decomposition of ESP goods and services imports by exporting country

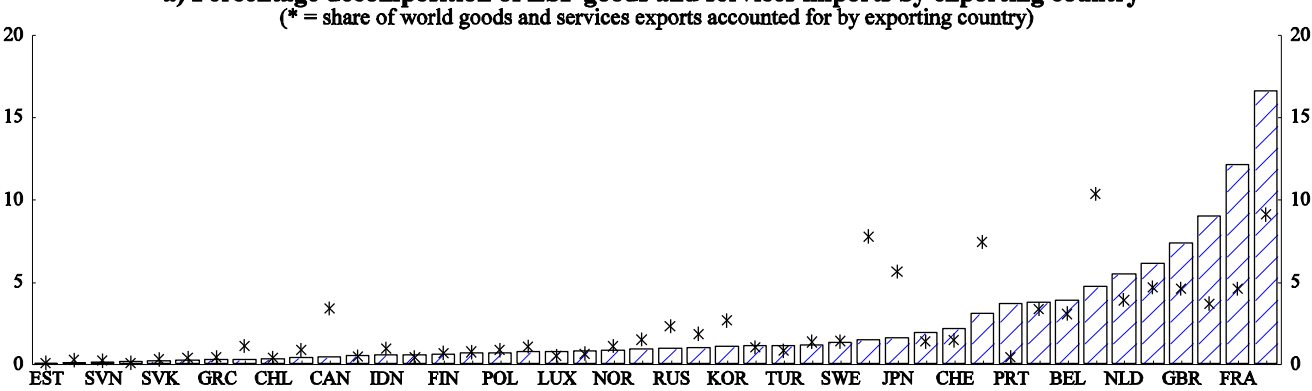
NZL ISL ISR AUS IND ZAF ARG CZE BRA HUN SAU MEX DNK AUT DAE IRL CHN ROW USA OIL ITA DEU

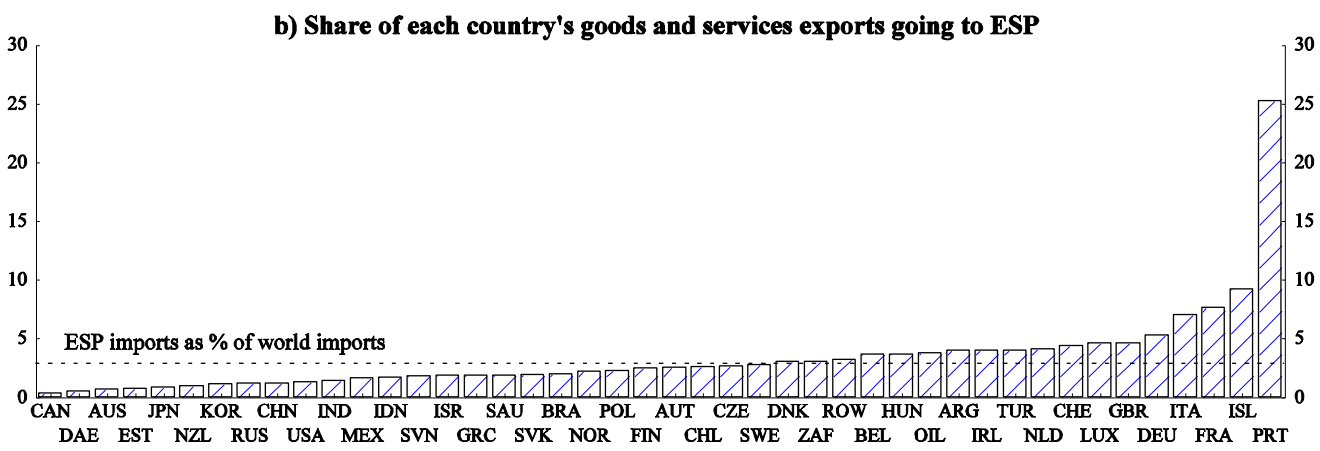

c) Percentage decomposition of ESP goods and services exports by importing country
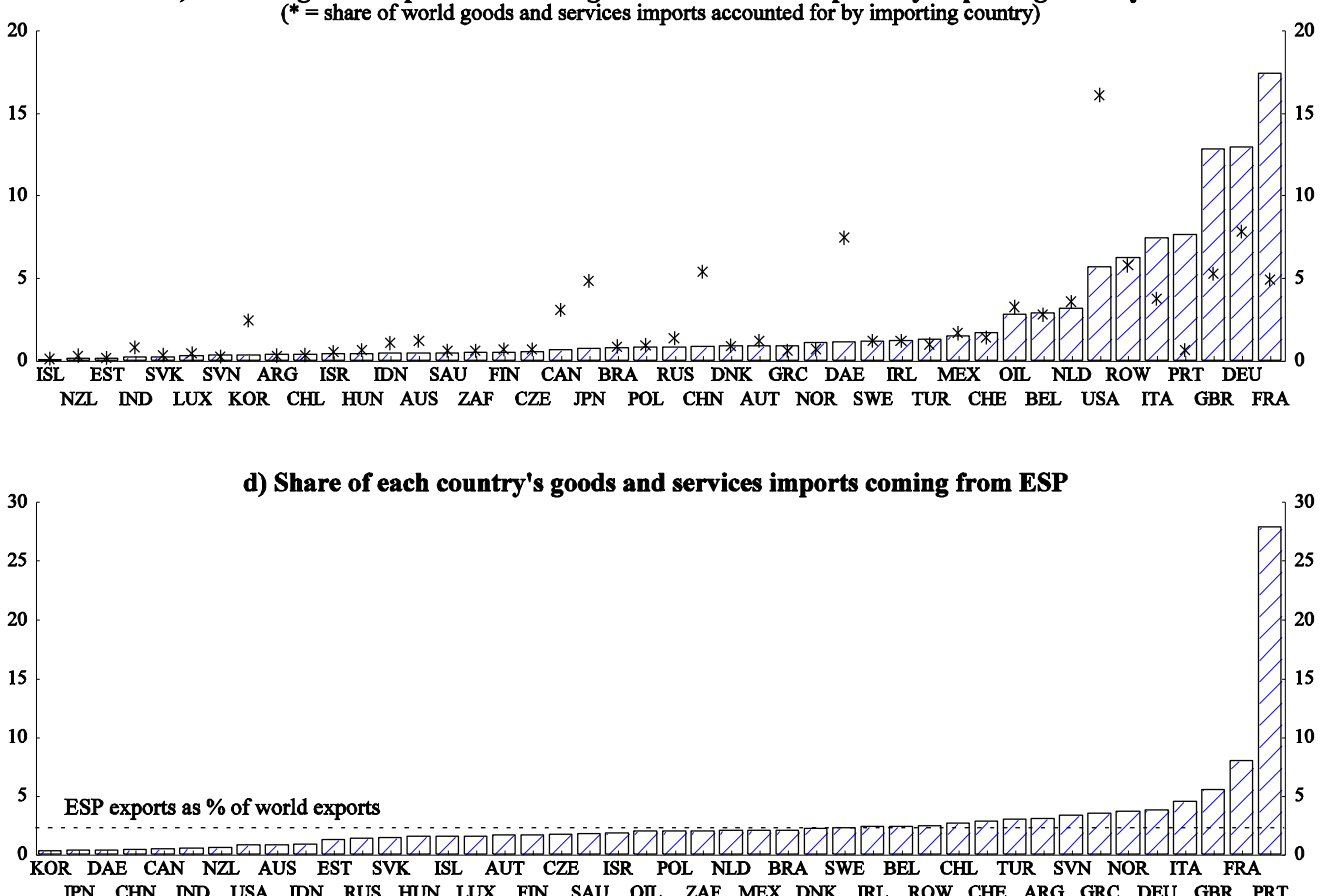
Figure 3.31. Geographical structure of goods and services trade of Sweden (SWE)

a) Percentage decomposition of SWE goods and services imports by exporting country

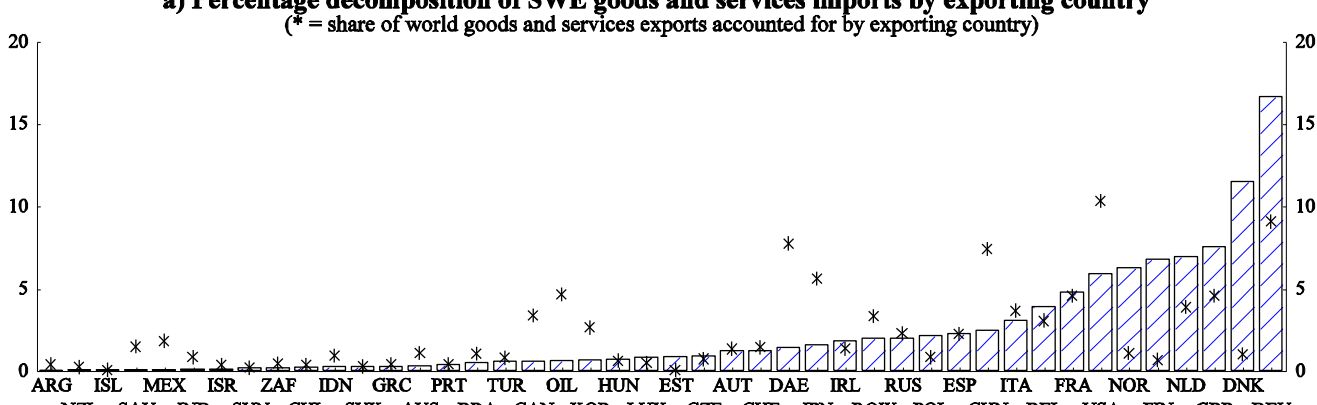

NZL SAU IND SVN CHL SVK AUS BRA CAN KOR LUX CZE CHE JPN ROW POL CHN BEL USA FIN GBR DEU

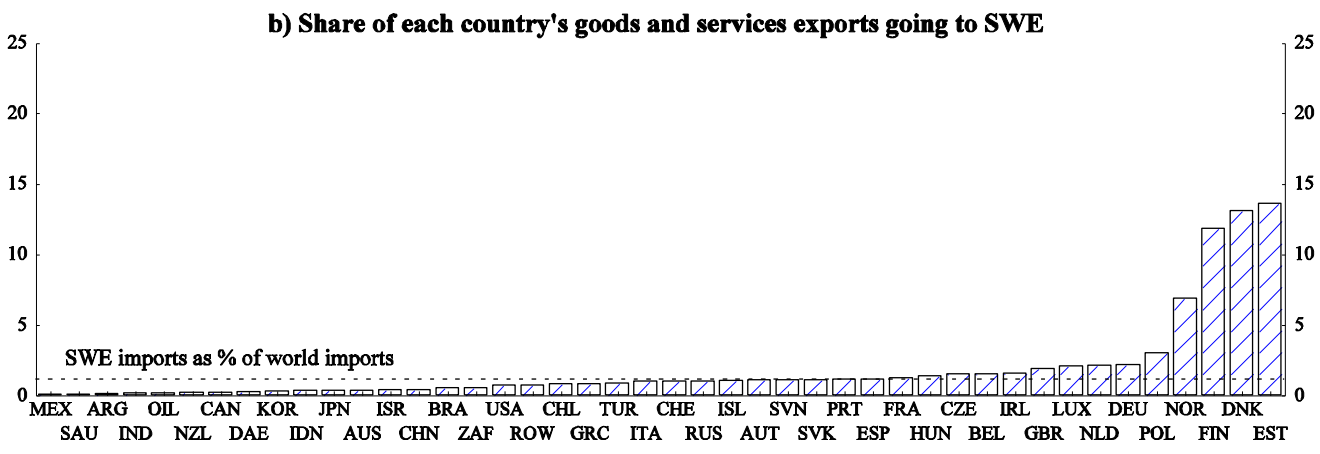

c) Percentage decomposition of SWE goods and services exports by importing country
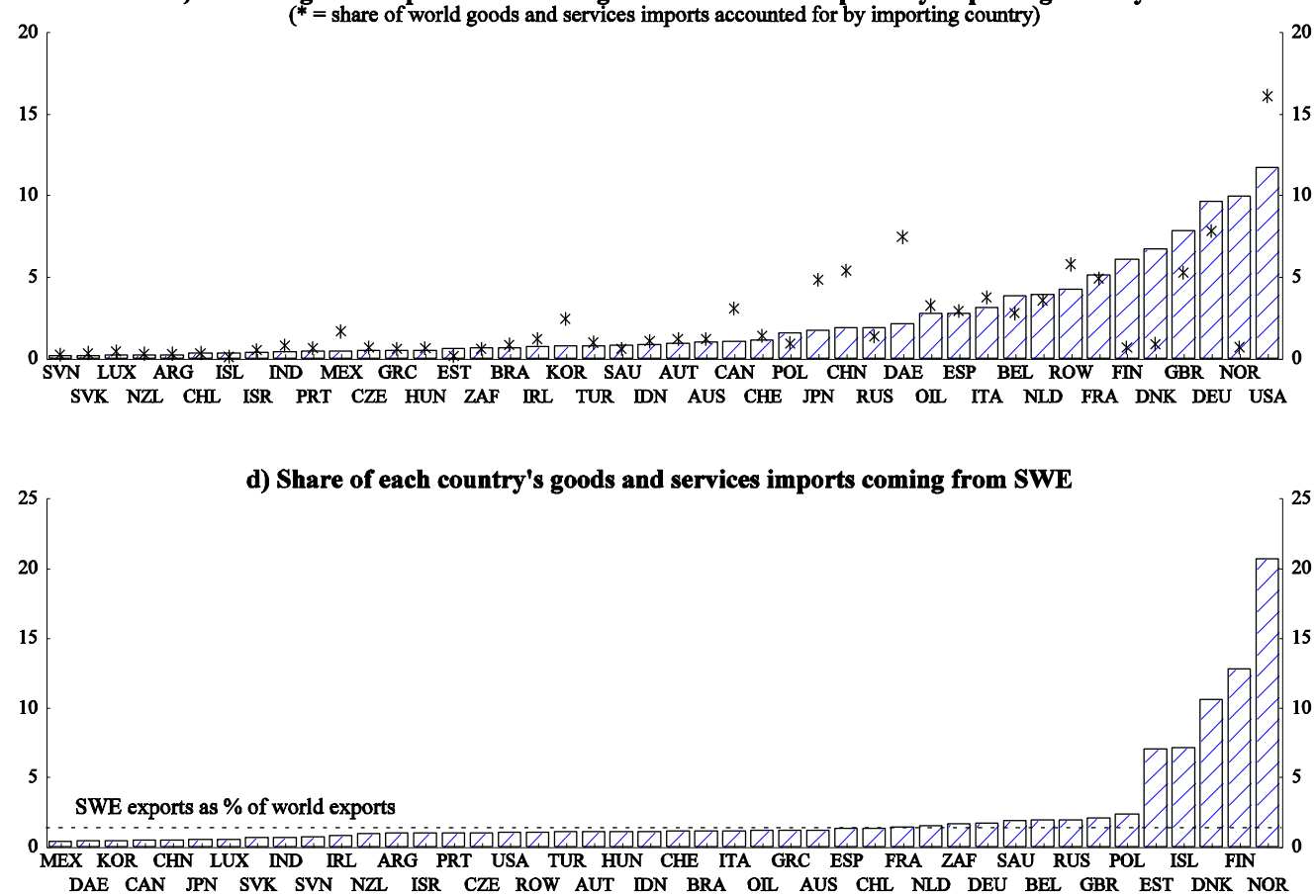
Figure 3.32. Geographical structure of goods and services trade of Switzerland (CHE)

a) Percentage decomposition of CHE goods and services imports by exporting country

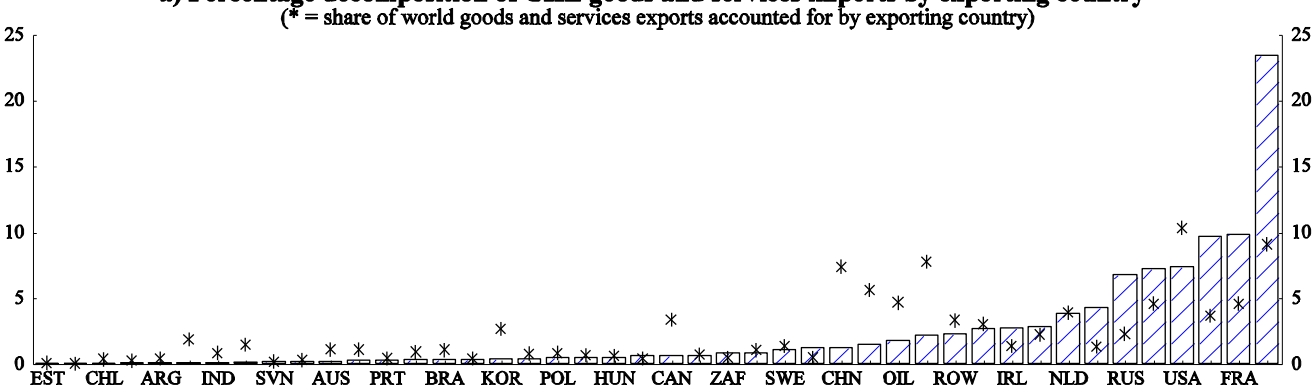

ZAF SWE CHPN DAE BEL ESP AUT GBR ITA DEU

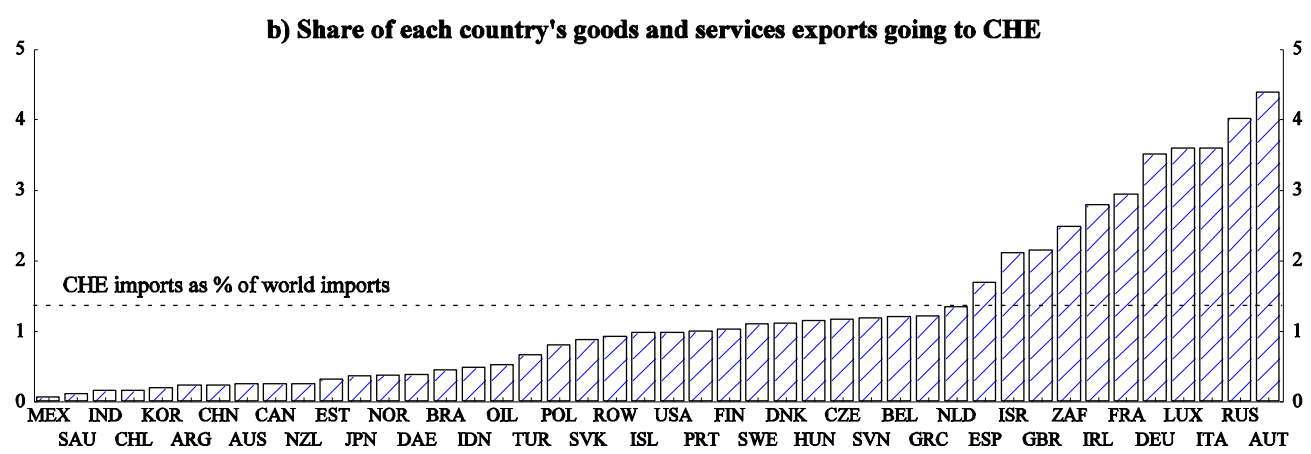

c) Percentage decomposition of CHE goods and services exports by importing country

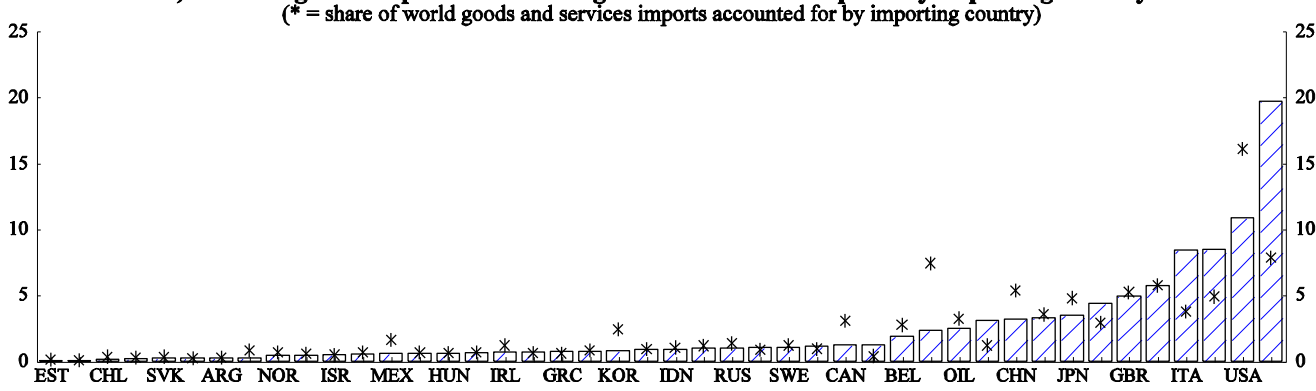

ISL NZL SVN IND ZAF FIN PRT CZE SAU BRA POL AUS DNK TUR LUX DAE AUT NLD ESP ROW FRA DEU

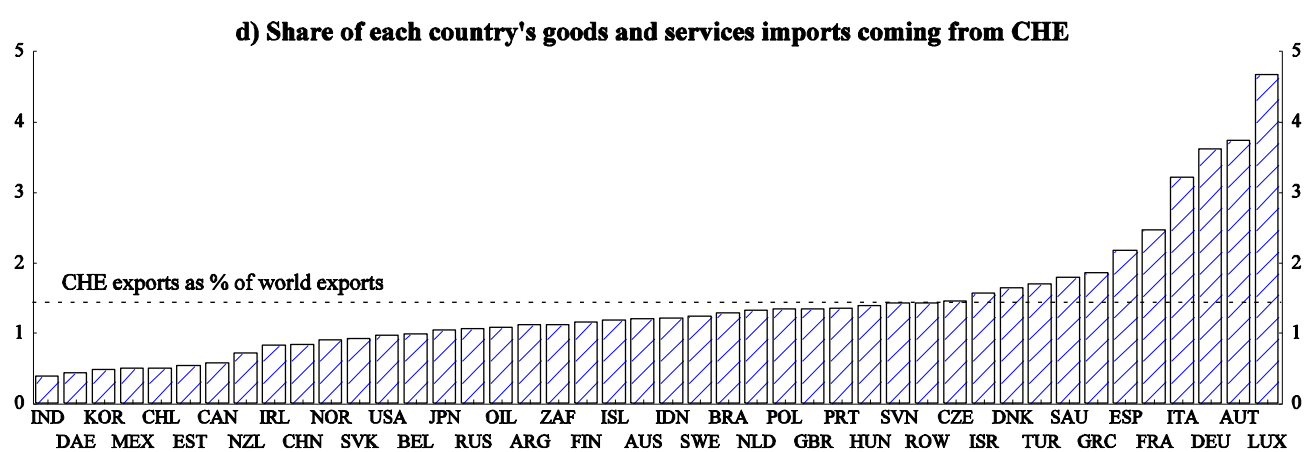


Figure 3.33. Geographical structure of goods and services trade of Turkey (TUR)

a) Percentage decomposition of TUR goods and services imports by exporting country

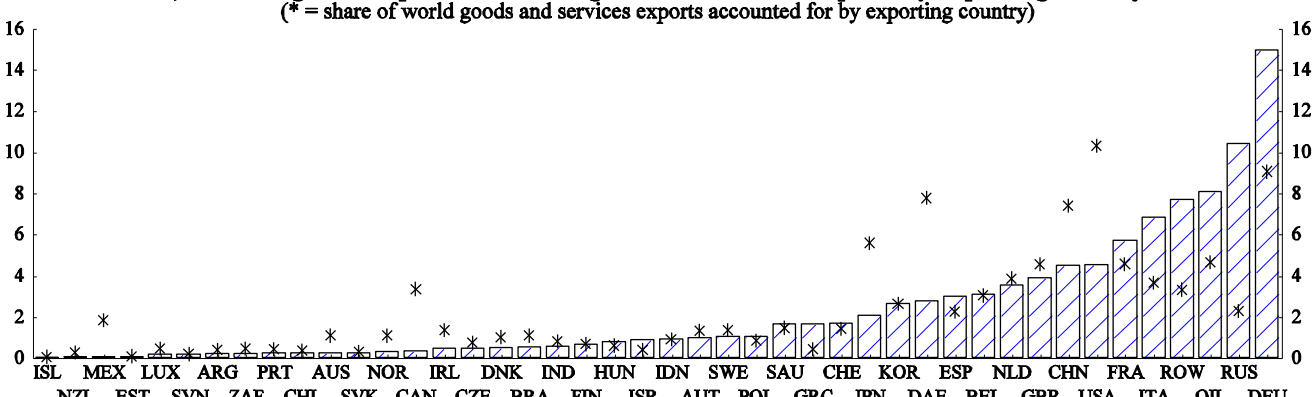
NZL EST SVN ZAF CHL SVK CAN CZE BRA FIN ISR AUT POL GR IPN DAE BEL GBR USA ITA OIL DEU

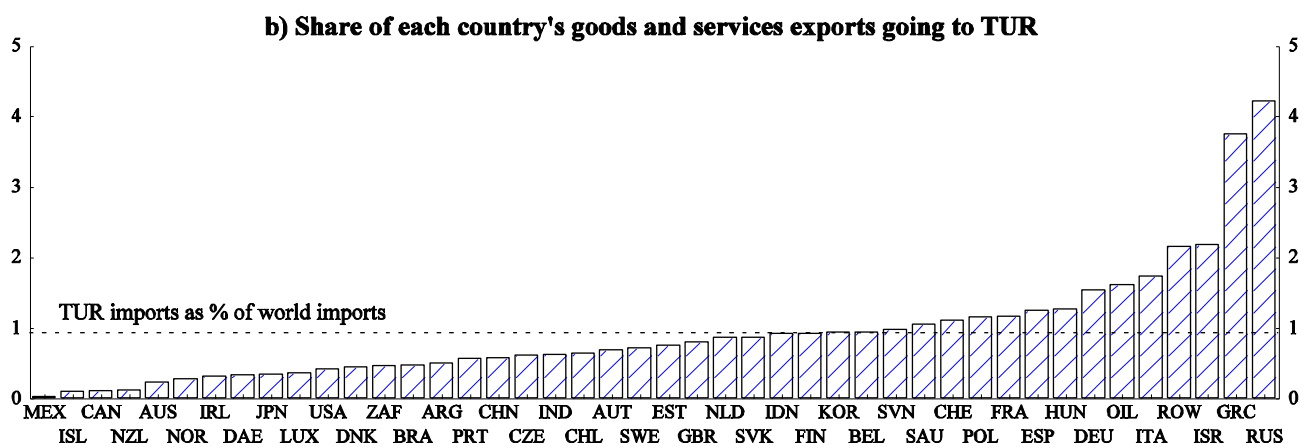

c) Percentage decomposition of TUR goods and services exports by importing country
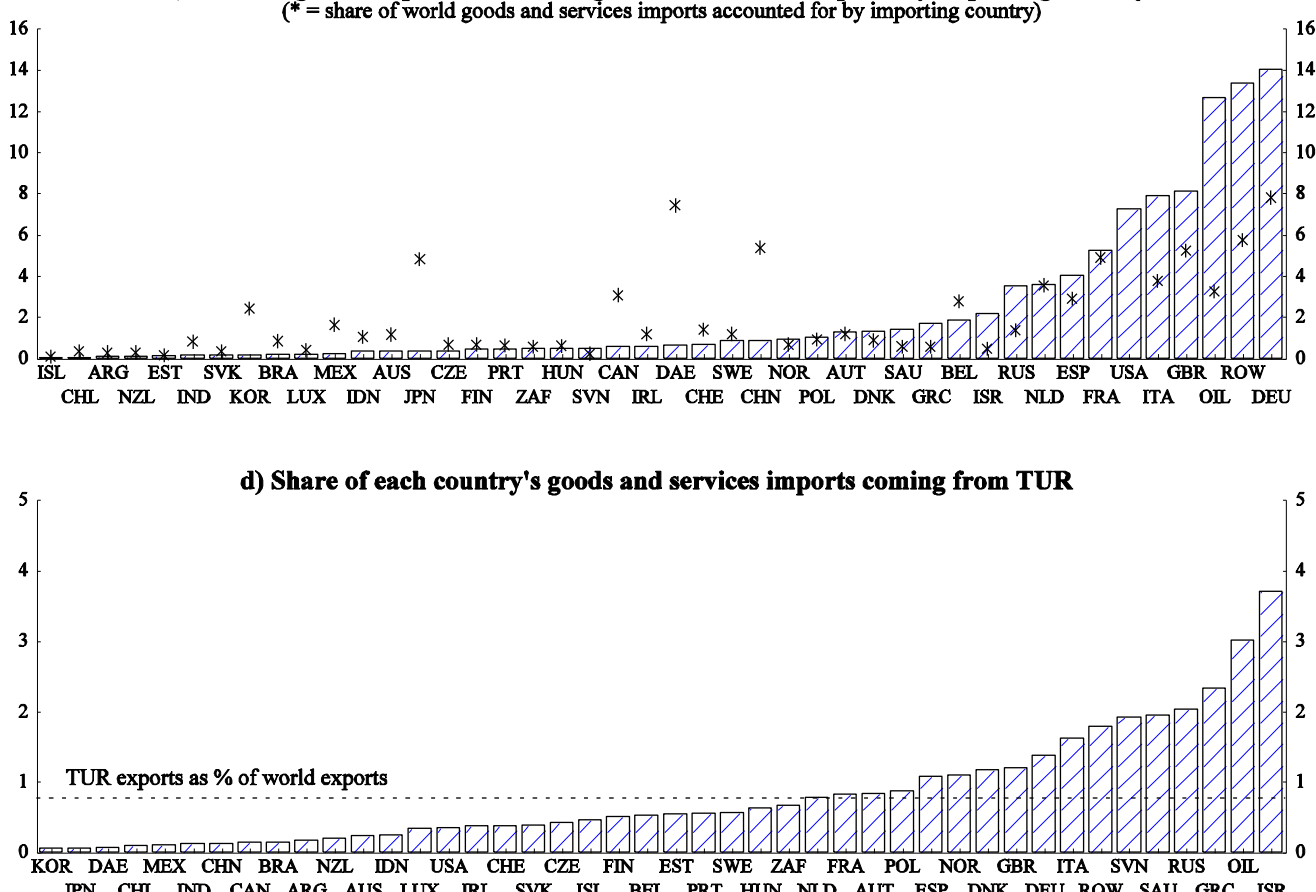
Figure 3.34. Geographical structure of goods and services trade of Argentina (ARG)

a) Percentage decomposition of ARG goods and services imports by exporting country

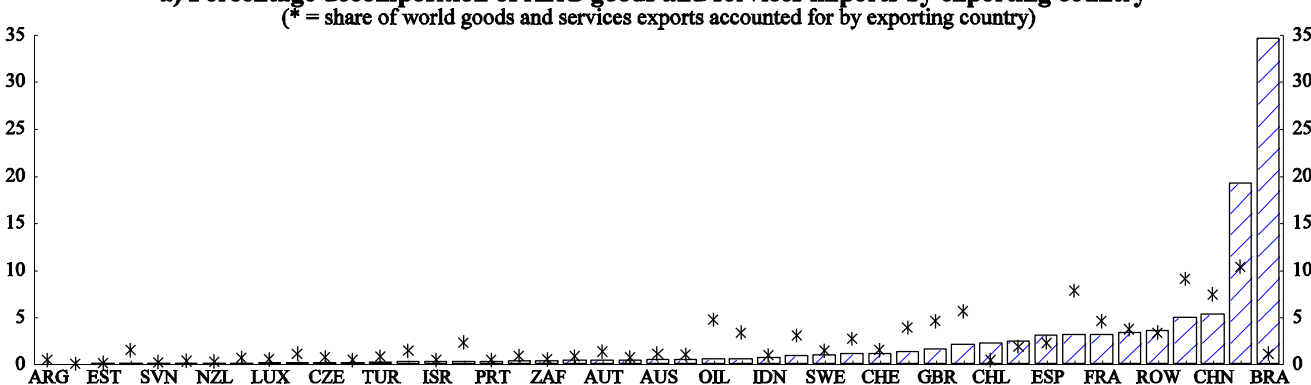

ISL SAU SVK HUN NOR GRC IRL RUS POL IND FIN DNK CAN BEL KOR NLD JPN MEX DAE ITA DEU USA

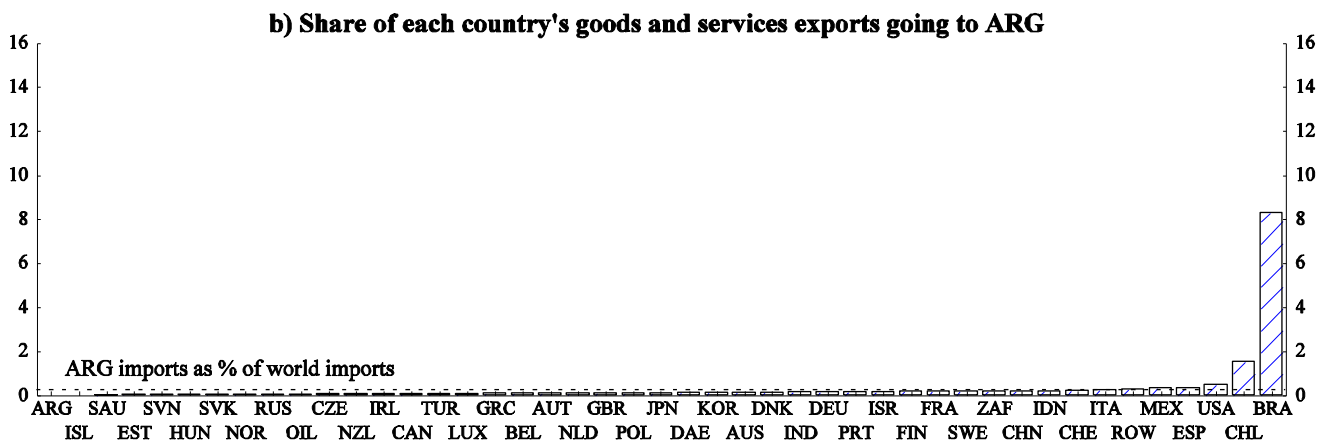

c) Percentage decomposition of ARG goods and services exports by importing country

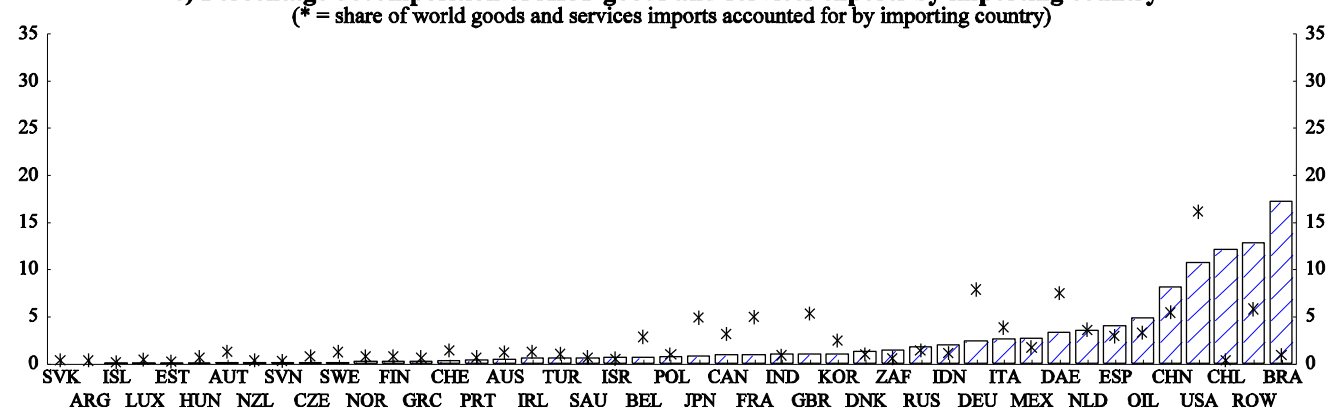

ARG LUX HUN NZI CZE NOR GRC PRT IRL SAU BEL IPN FRA GBR DNK RUS DEU MEX ND CL USA ROW

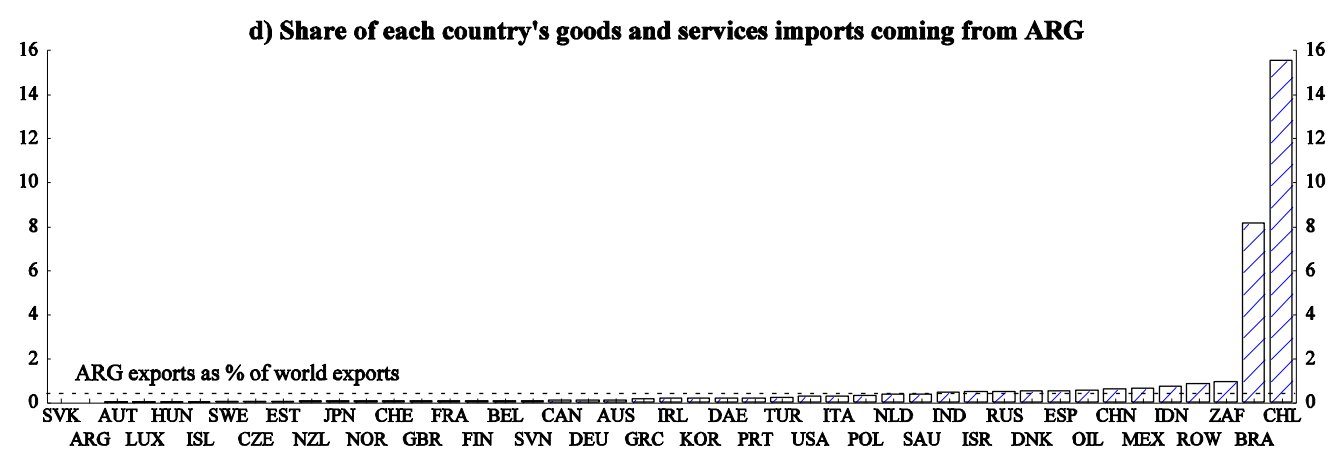


Figure 3.35. Geographical structure of goods and services trade of Brazil (BRA)

a) Percentage decomposition of BRA goods and services imports by exporting country

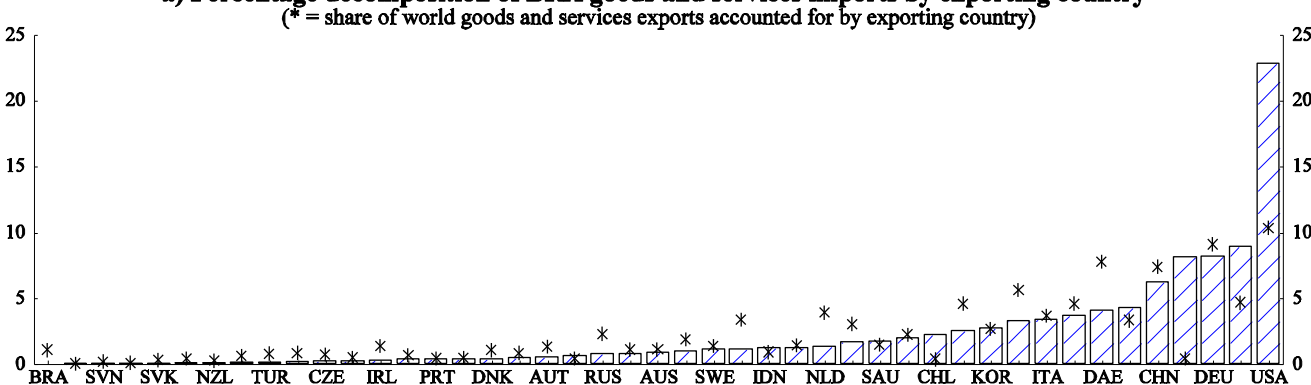

ISL EST GRC HUN POL LUX FIN ZAF IND ISR NOR MEX CAN CHE BEL ESP GBR JPN FRA ROW ARG OIL

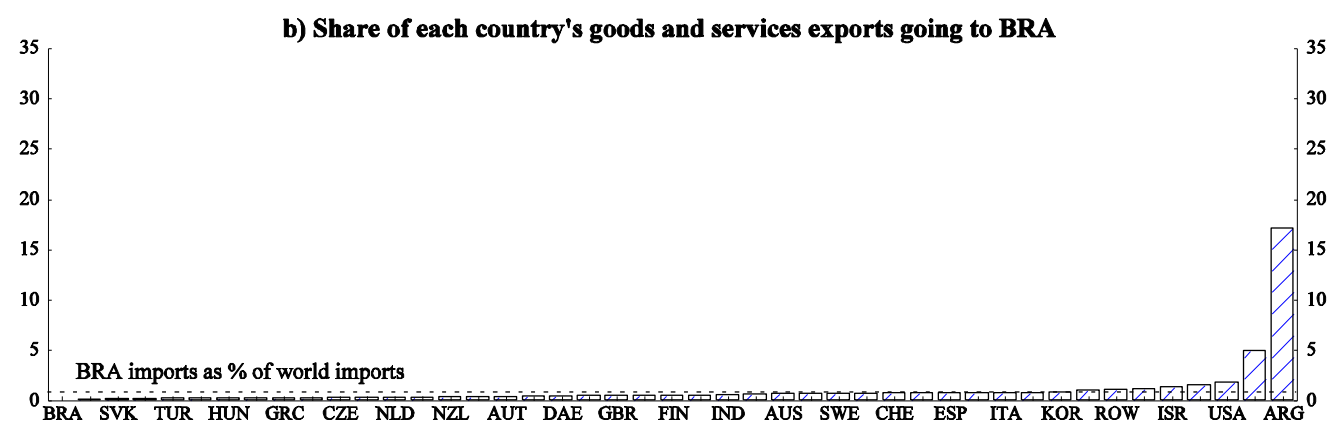

ISL SVN POL IRL EST RUS CAN DNK LUX MEX BEL JPN NOR FRA CHN DEU ZAF PRT SAU IDN OIL CHL

c) Percentage decomposition of BRA goods and services exports by importing country

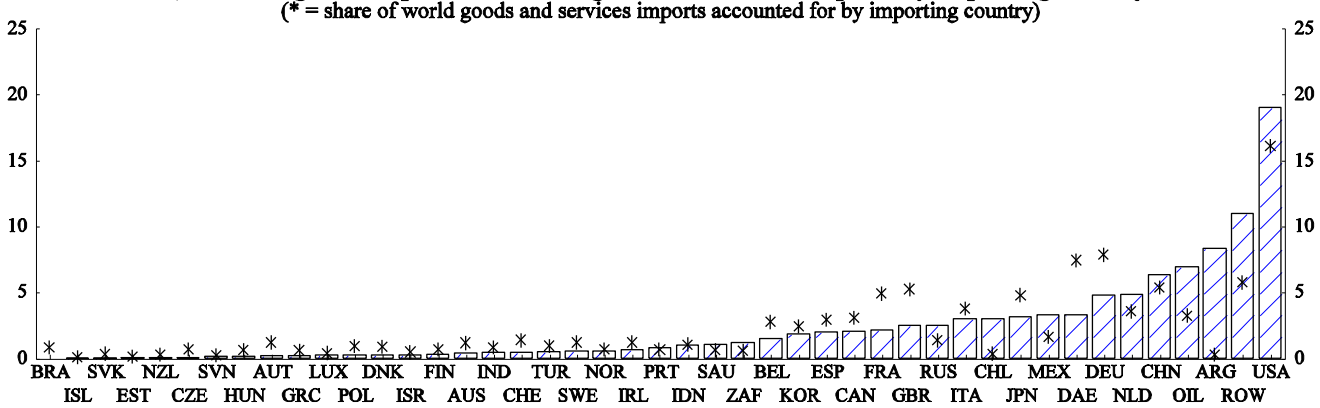

d) Share of each country's goods and services imports coming from BRA

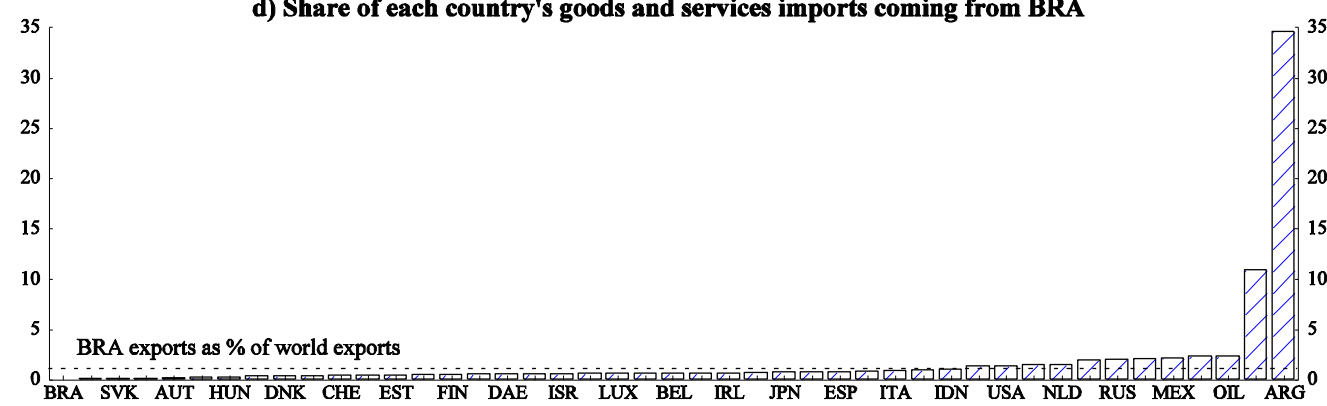

ISL CZE NZL POL GRC AUS FRA SWE GBR TUR IND SVN DEU CAN KOR NOR CHN PRT SAU ROW ZAF CHL 
Figure 3.36. Geographical structure of goods and services trade of China (CHN)

a) Percentage decomposition of CHN goods and services imports by exporting country

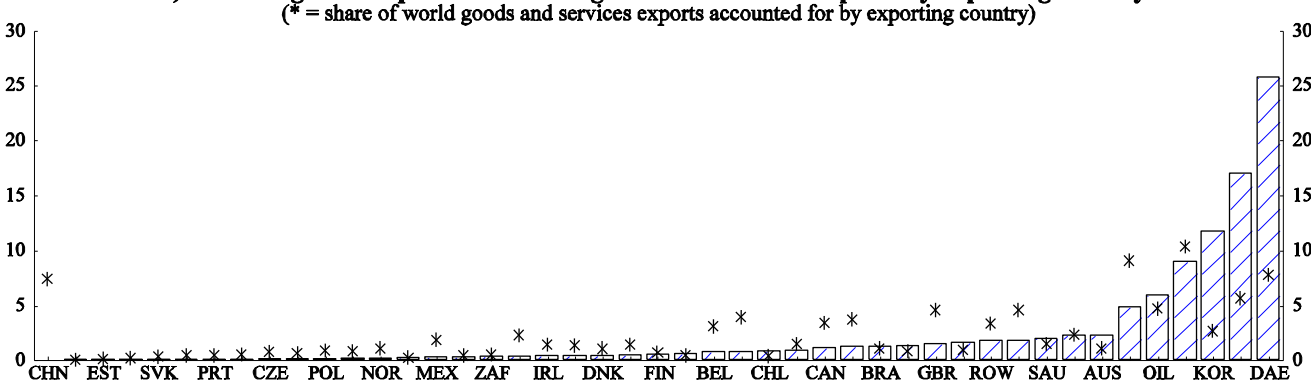

ISL SVN GRC LUX HUN TUR NZL ISR ESP AUT SWE ARG NLD CHE ITA IND IDN FRA RUS DEU USA JPN

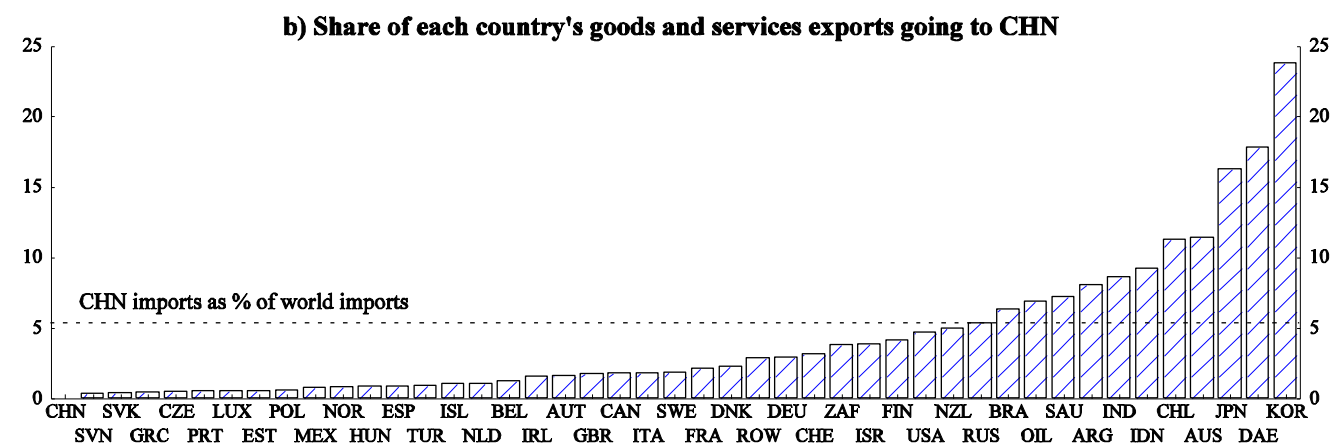

c) Percentage decomposition of CHN goods and services exports by importing country

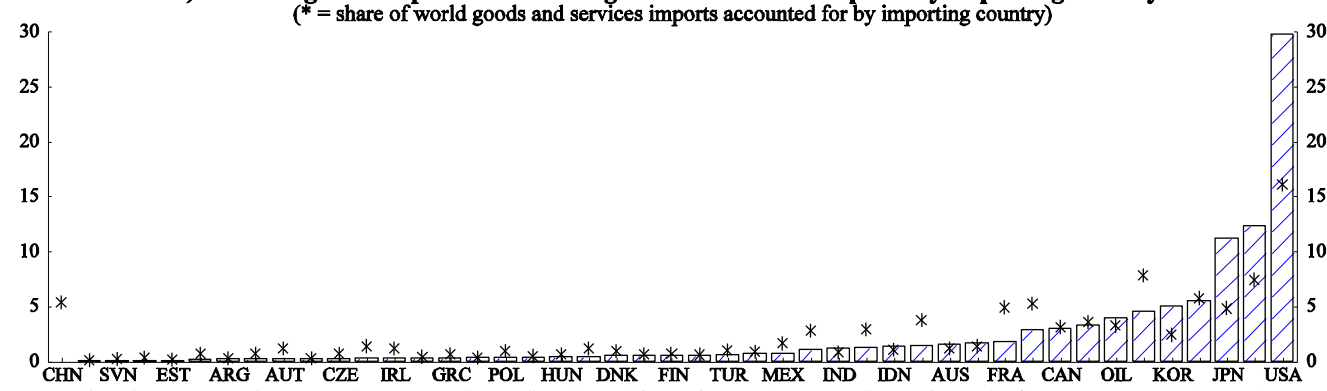

ISL SVK PRT NOR NZT IN GR IDN AUS FRA CAN OIL KOR JPN USA

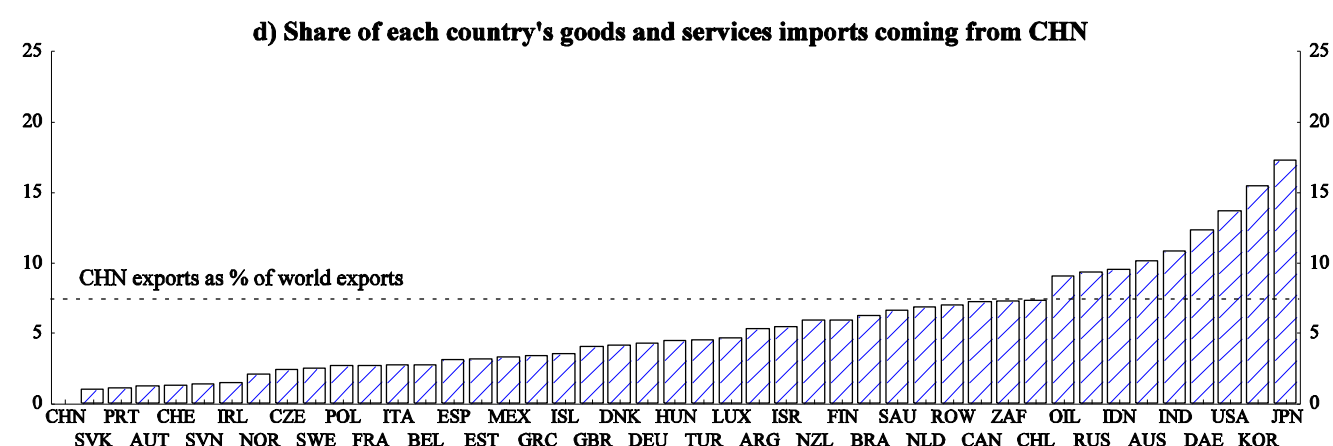


Figure 3.37. Geographical structure of goods and services trade of Estonia (EST)

a) Percentage decomposition of EST goods and services imports by exporting country

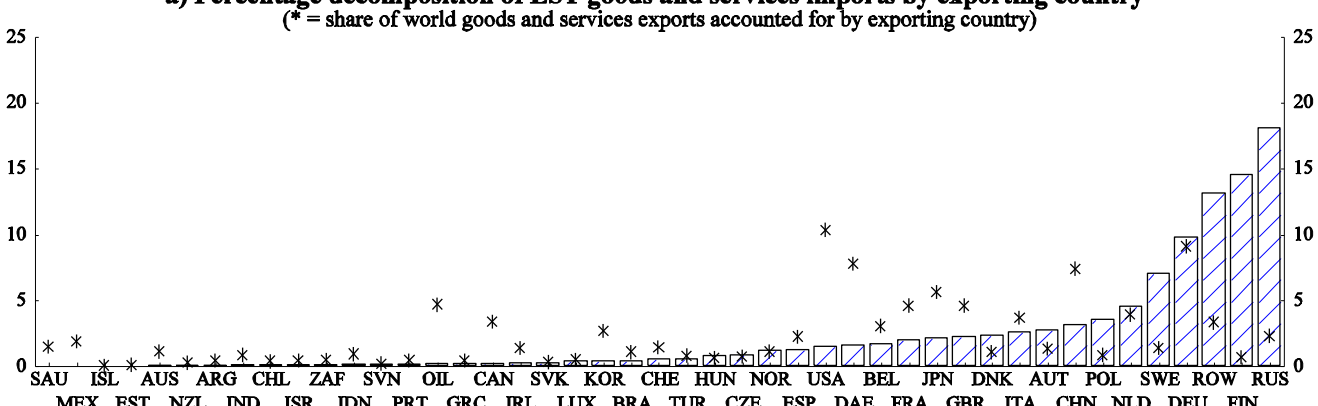

MEX EST NZL IND ISR IDN PRT GRC IRL LUX BRA TUR CZE ESP DAE FRA GBR ITA CHN NLD DEU FIN

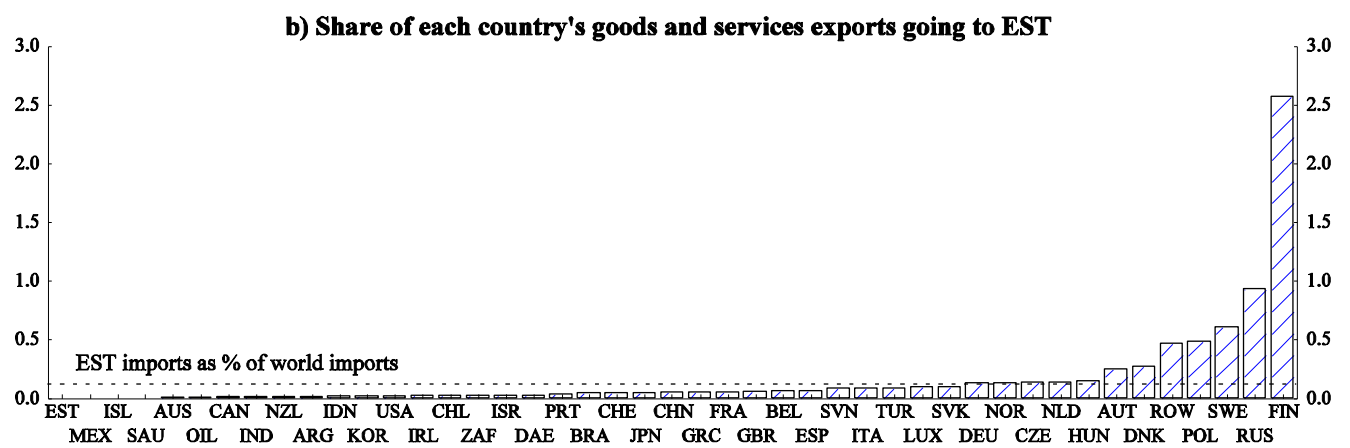

c) Percentage decomposition of EST goods and services exports by importing country
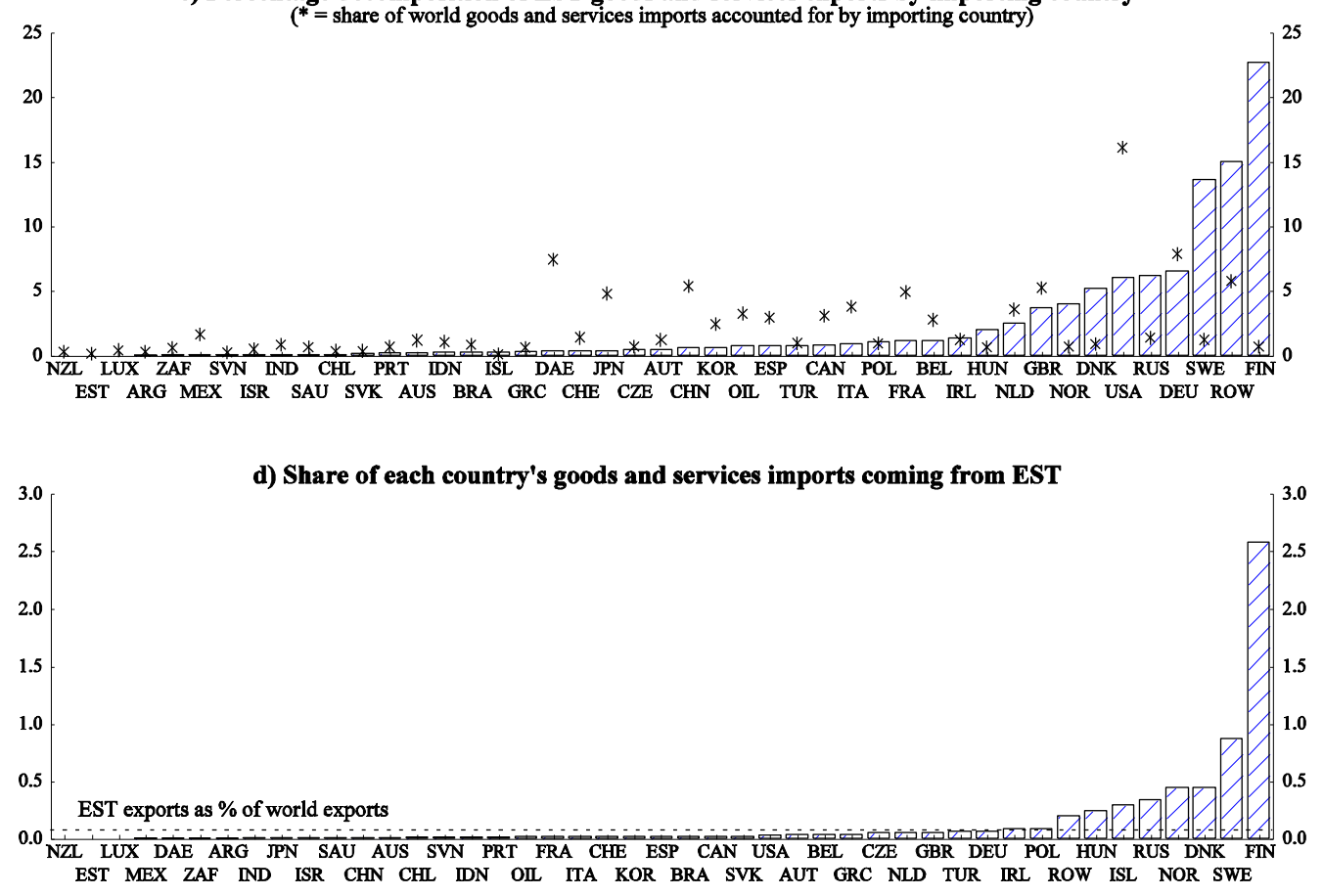
Figure 3.38. Geographical structure of goods and services trade of India (IND)

a) Percentage decomposition of IND goods and services imports by exporting country

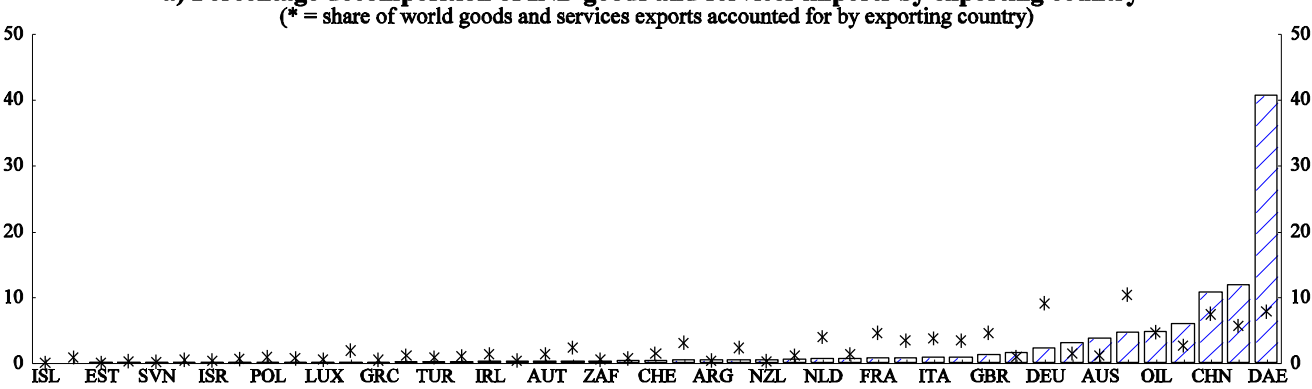
IND SVK PRT HUN CZE MEX NOR DNK CHL RUS FIN BEL ESP BRA SWE CAN ROW IDN SAU USA KOR JPN

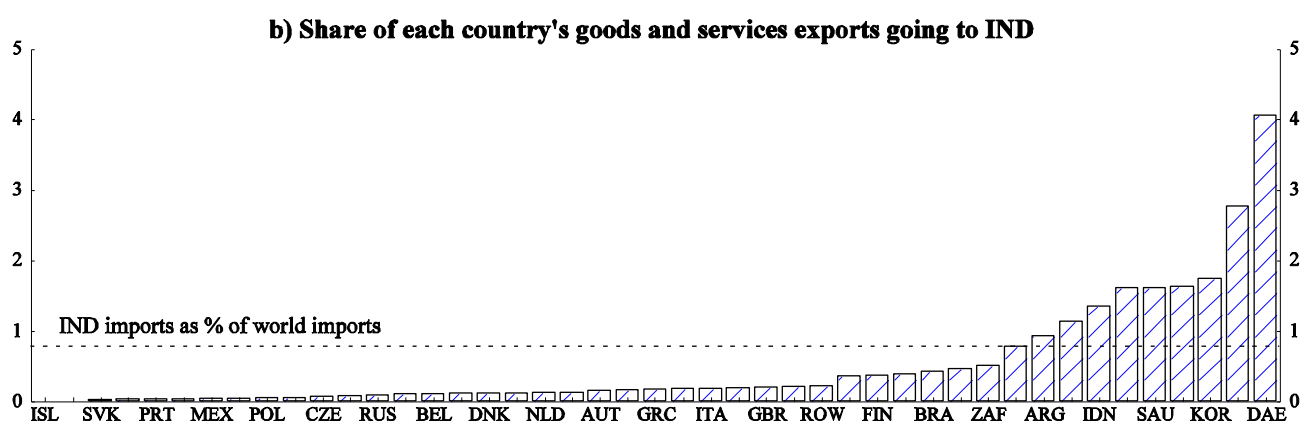

IND SVN HUN ISR EST NOR LUX IRL TUR FRA ESP CAN DEU CHE USA SWE CHL OIL CHN NZL JPN AUS

c) Percentage decomposition of IND goods and services exports by importing country

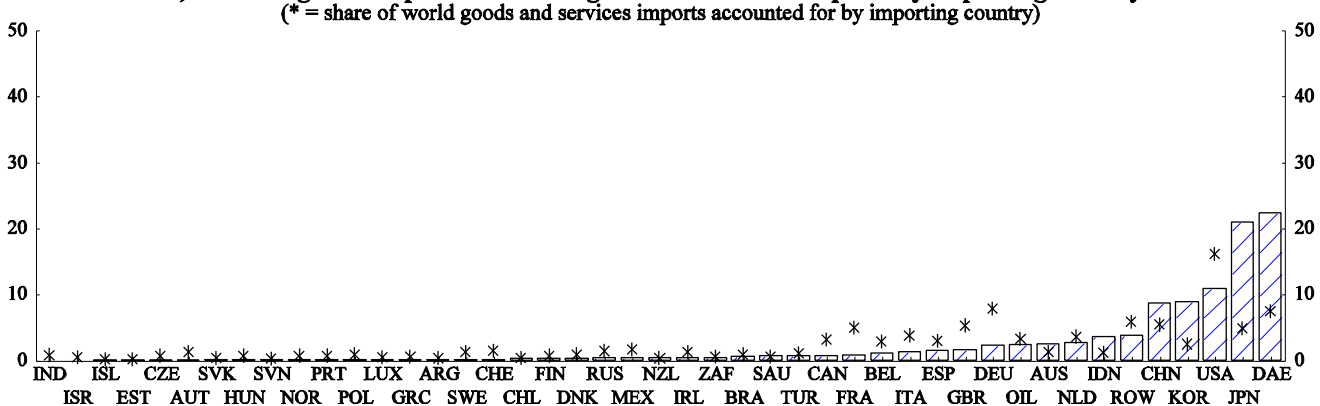

d) Share of each country's goods and services imports coming from IND

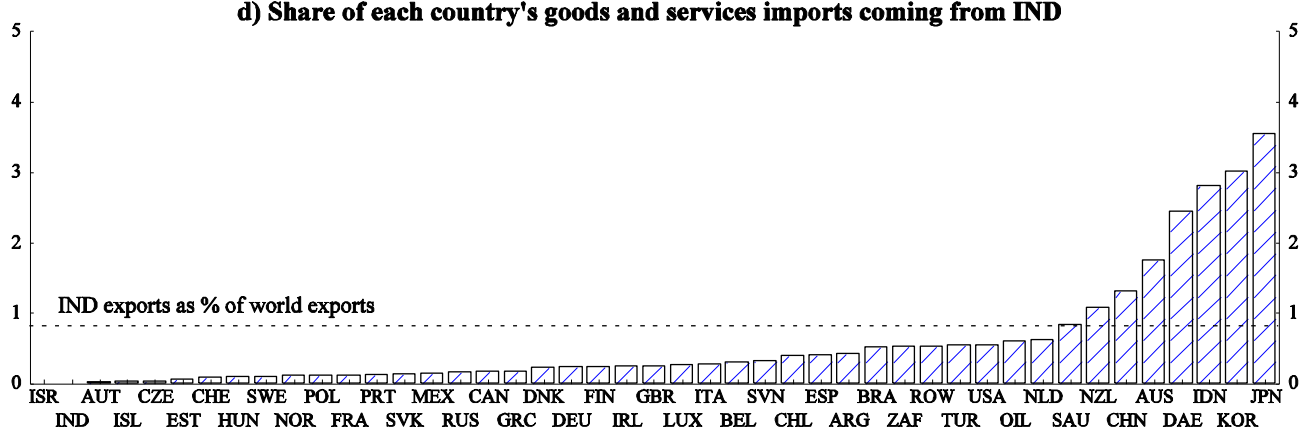


Figure 3.39. Geographical structure of goods and services trade of Indonesia (IDN)

a) Percentage decomposition of IDN goods and services imports by exporting country $(*=$ share of world goods and services exports accounted for by exporting country)

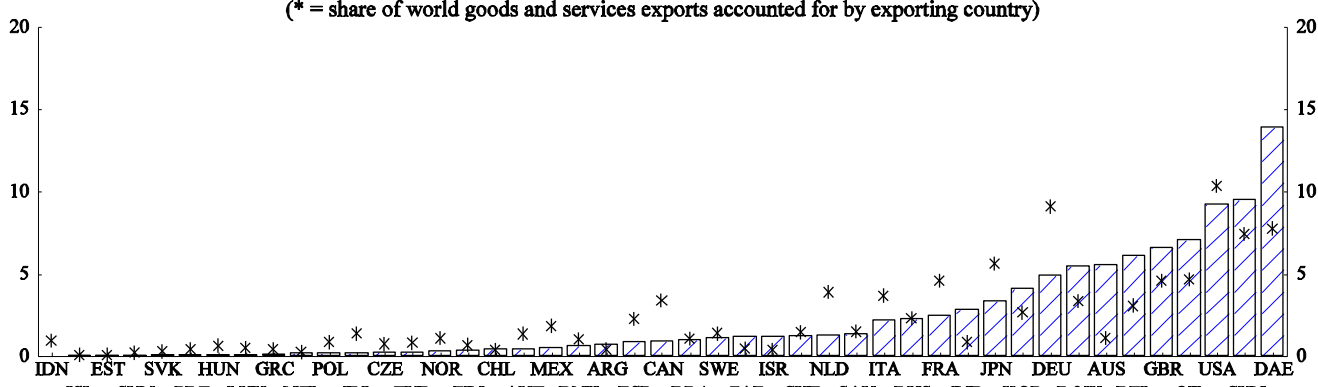

ISL SVN PRT LUX NZL IRL TUR FIN AUT DNK ESP BRA ZAF CHE SAU RUS IND KOR ROW BEL OIL CHN

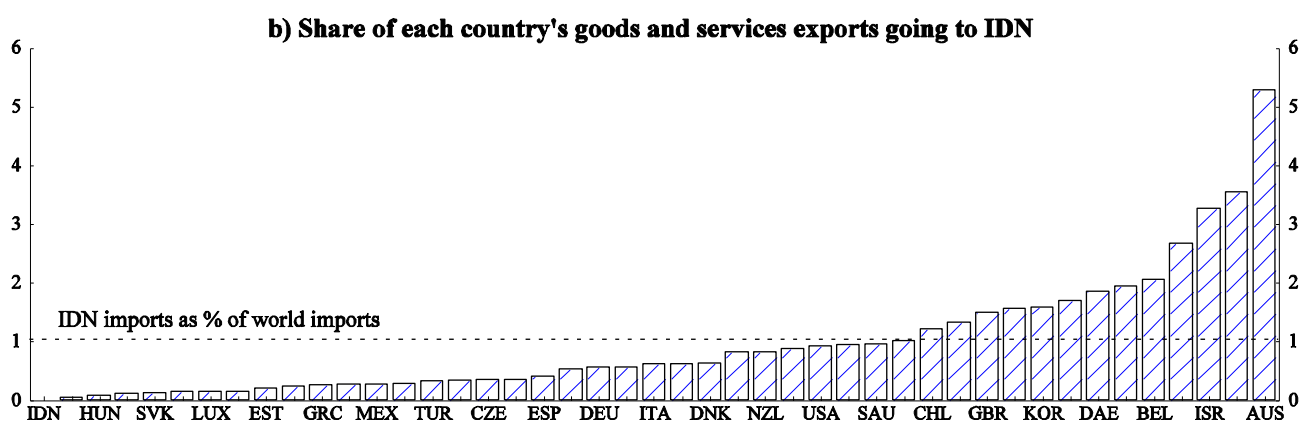

ISL PRT SVN IRL POL CAN NOR NLD AUT FIN FRA JPN SWE CHE BRA RUS CHN OIL ROW ARG ZAF IND

c) Percentage decomposition of IDN goods and services exports by importing country

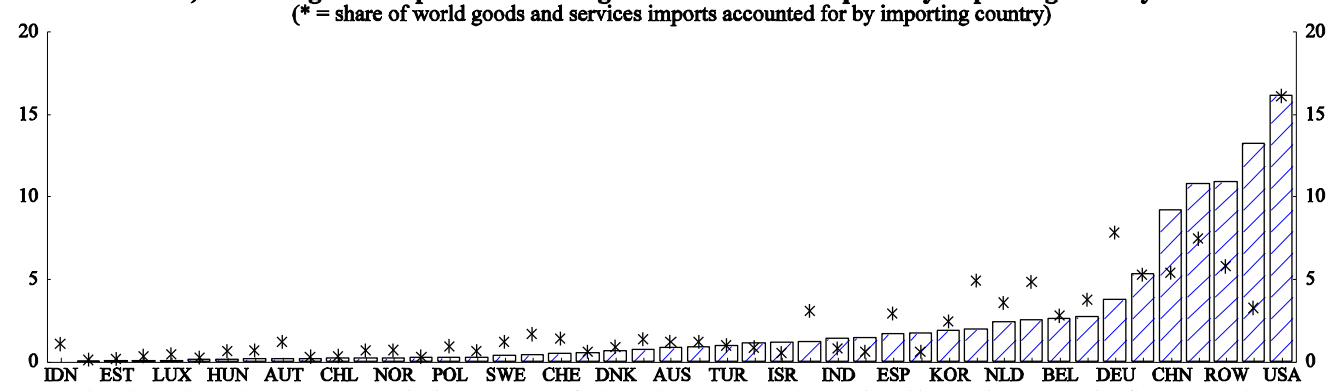

ISL SVK SVN CZE NZL FIN ARG PRT MEX GRC RUS IRL BRA CAN ZAF SAU FRA JPN ITA GBR DAE OIL

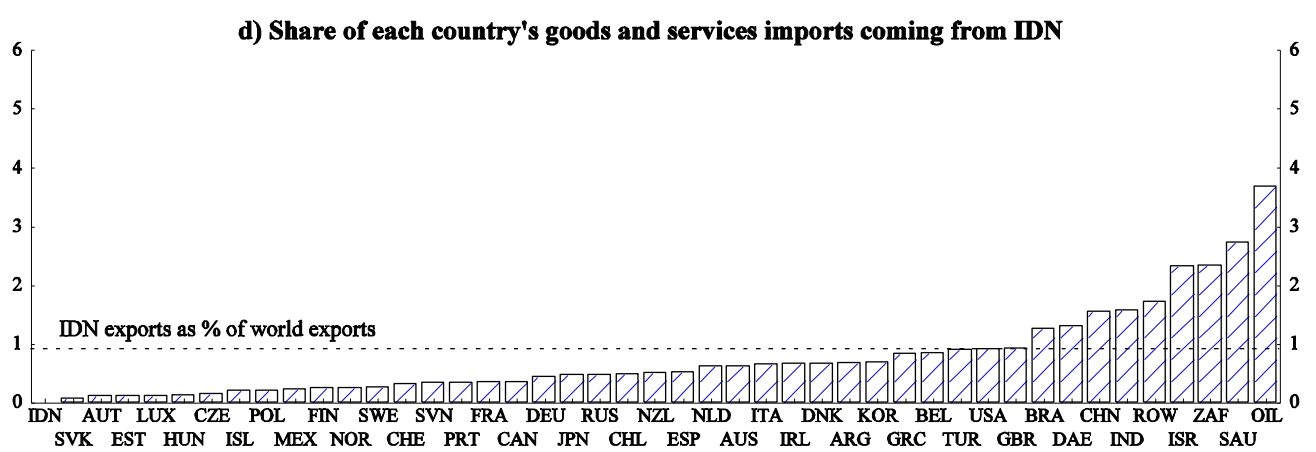


Figure 3.40. Geographical structure of goods and services trade of Israel (ISR)

a) Percentage decomposition of ISR goods and services imports by exporting country $\left(^{*}=\right.$ share of world goods and services exports accounted for by exporting country)

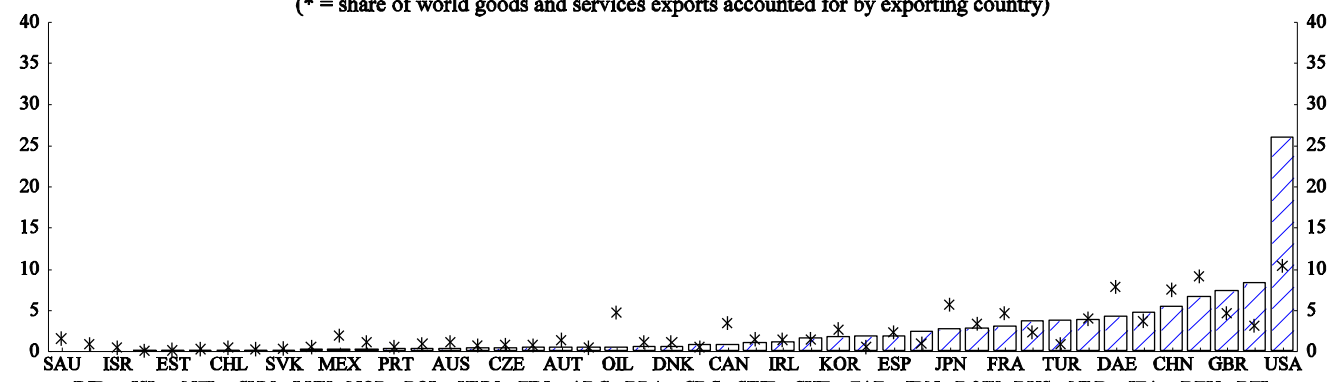

IND ISL NZL SVN LUX NOR POL HUN FIN ARG BRA GRC SWE CHE ZAF IDN ROW RUS NLD ITA DEU BEL

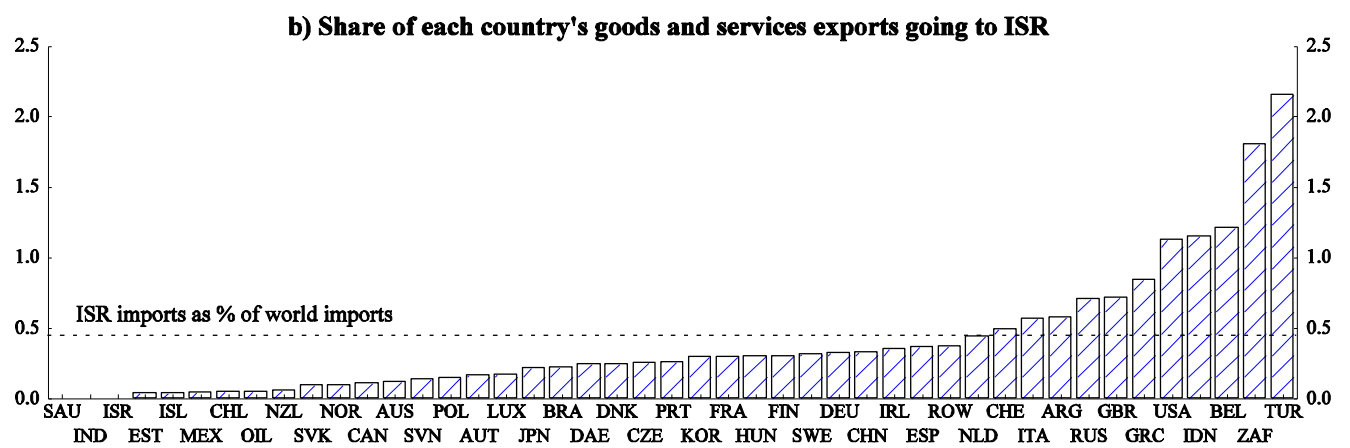

c) Percentage decomposition of ISR goods and services exports by importing country

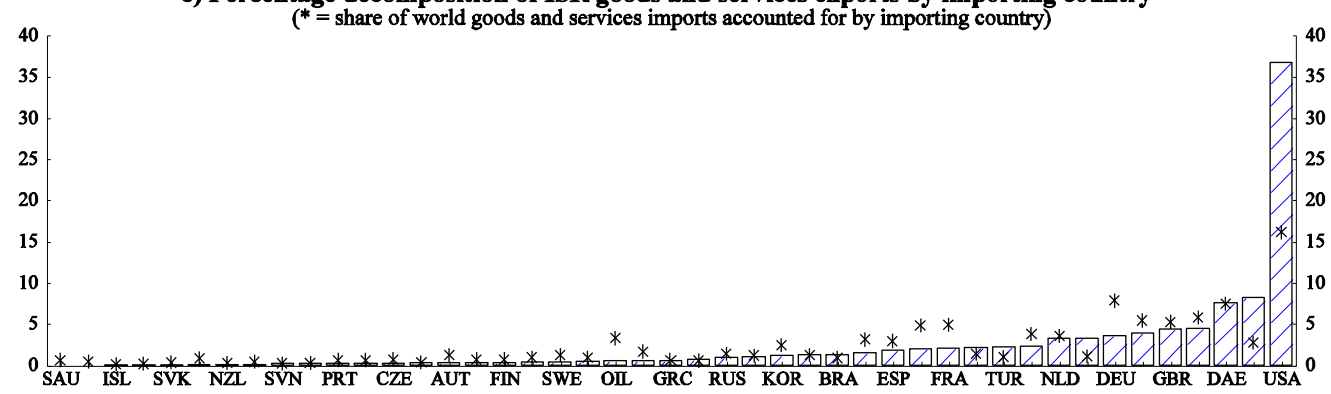

ISR EST IND LUX ARG HUN CHL NOR POL DNK MEX ZAF AUS IRL CAN JPN CHE ITA IDN CHN ROW BEL

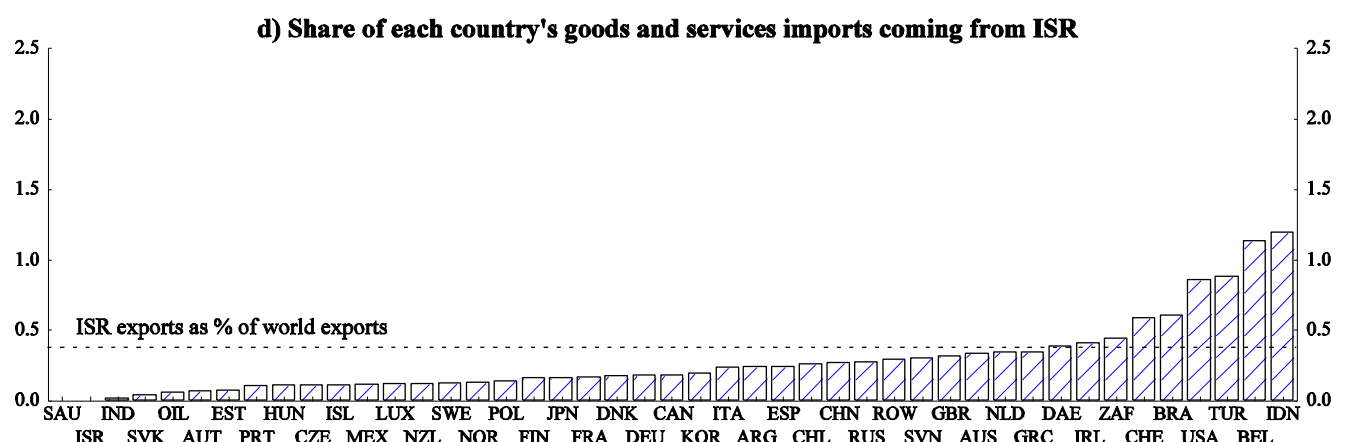


Figure 3.41. Geographical structure of goods and services trade of Russian Federation (RUS)

a) Percentage decomposition of RUS goods and services imports by exporting country

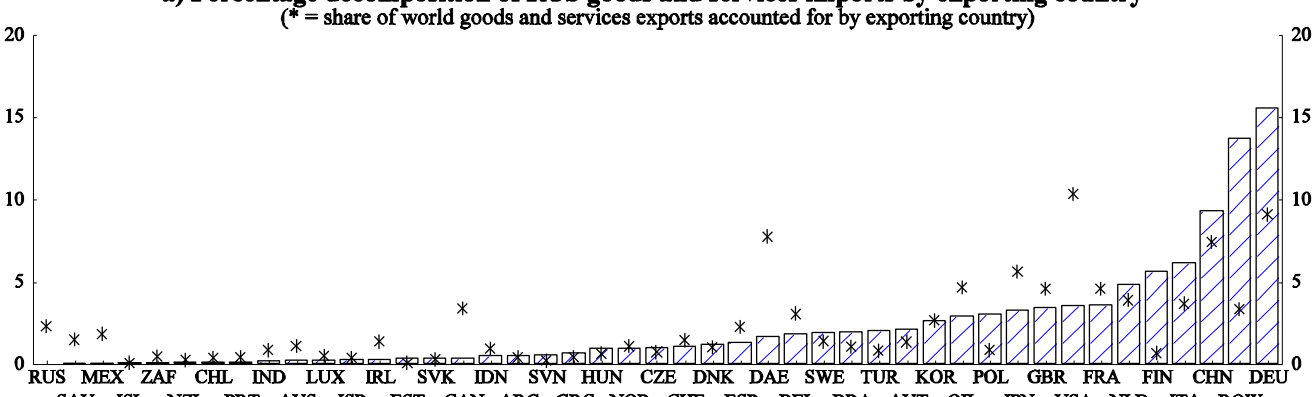

SAU ISL NZL PRT AUS ISR EST CAN ARG GRC NOR CHE ESP BEL BRA AUT OIL JPN USA NLD ITA ROW

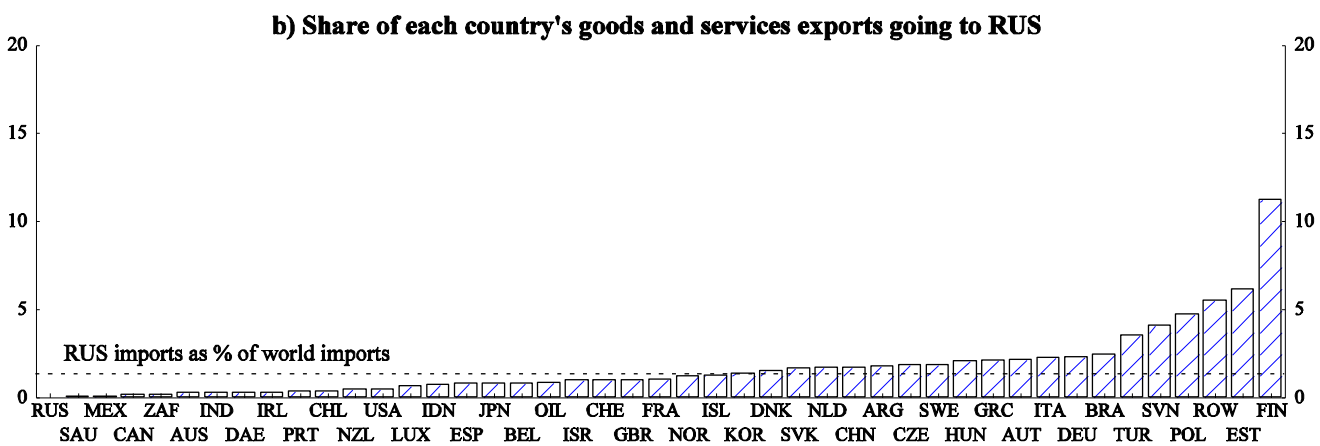

c) Percentage decomposition of RUS goods and services exports by importing country

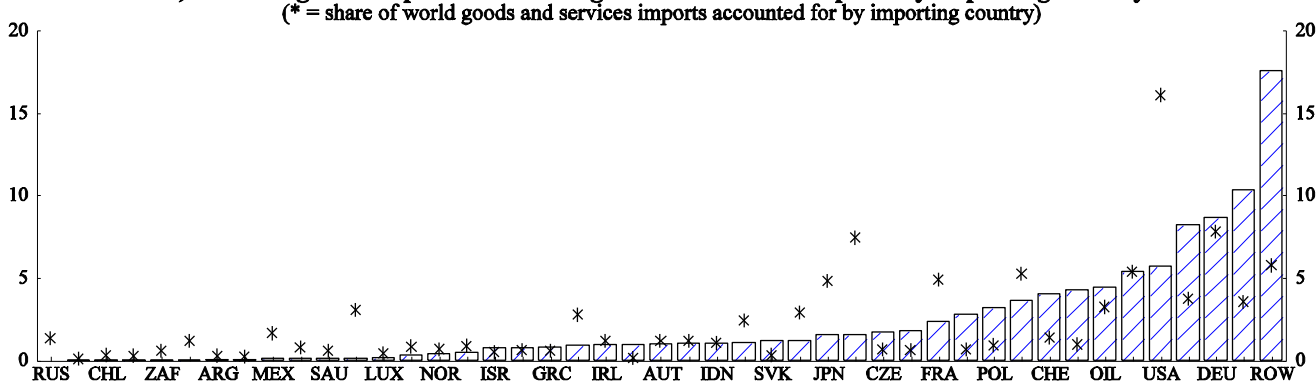

ISL NZL AUS SVN SAU LUX NA ISR GR IRL AUT IDN SVK JPN CZE FRA POL CHE OIL USA DEU

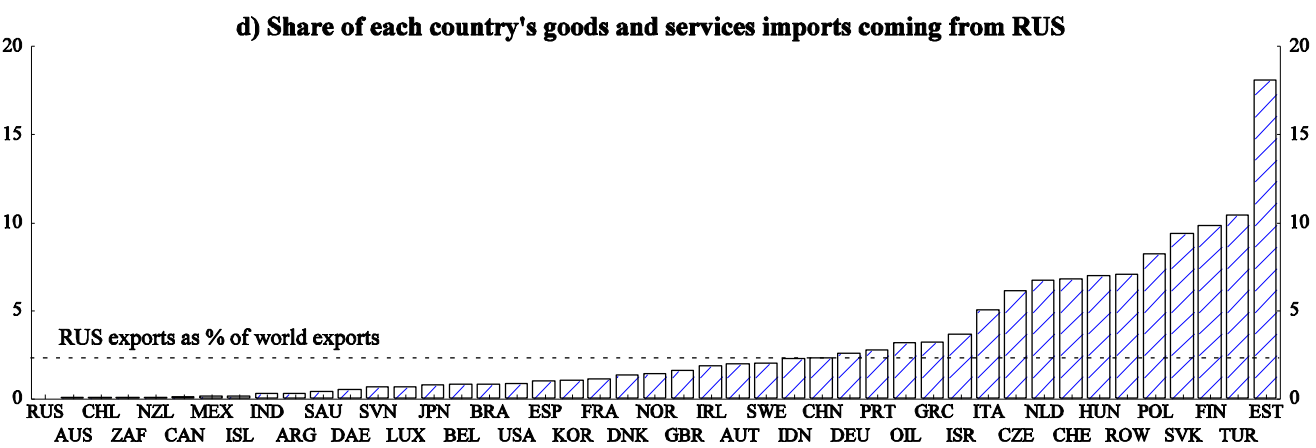


Figure 3.42. Geographical structure of goods and services trade of Saudi Arabia (SAU)

a) Percentage decomposition of SAU goods and services imports by exporting country $(*=$ share of world goods and services exports accounted for by exporting country)

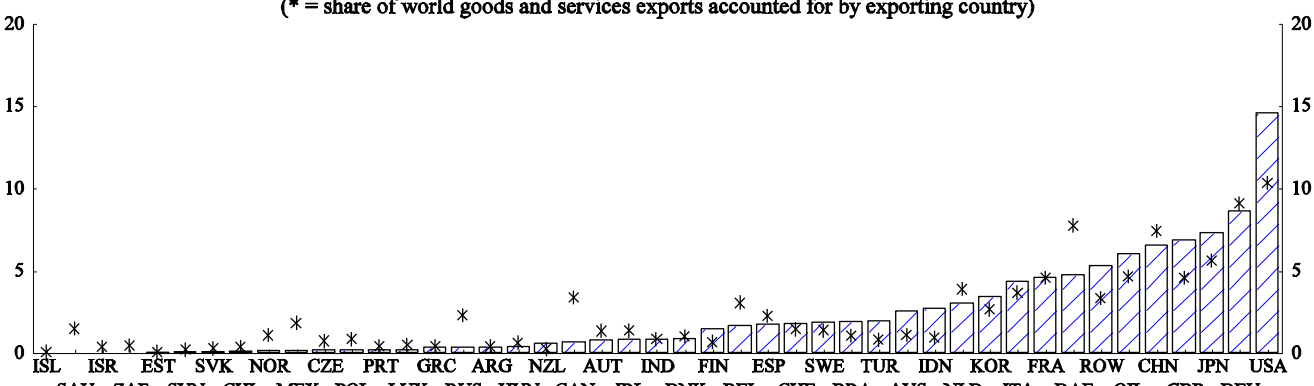

SAU ZAF SVN CHL MEX POL LUX RUS HUN CAN IRL DNK BEL CHE BRA AUS NLD ITA DAE OIL GBR DEU

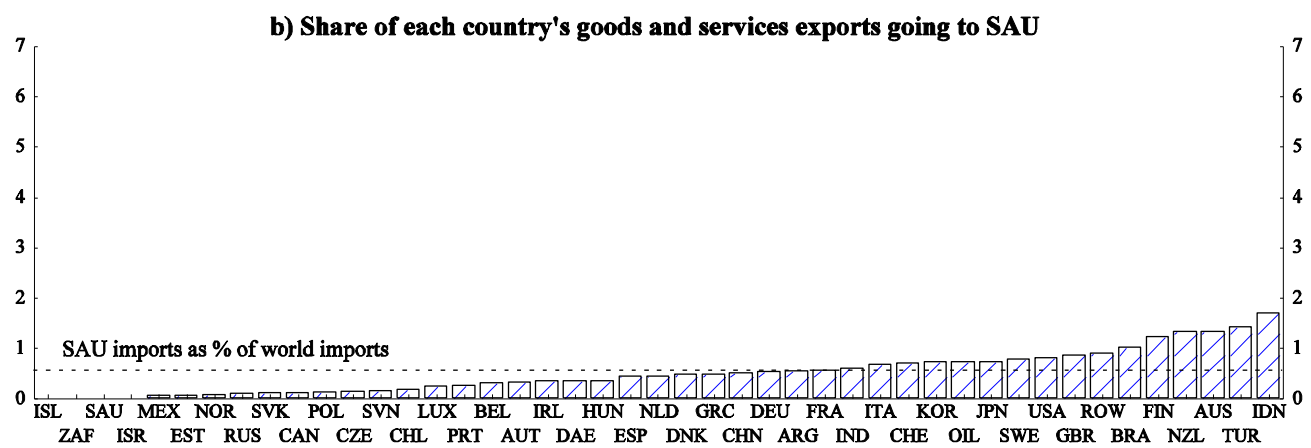

c) Percentage decomposition of SAU goods and services exports by importing country

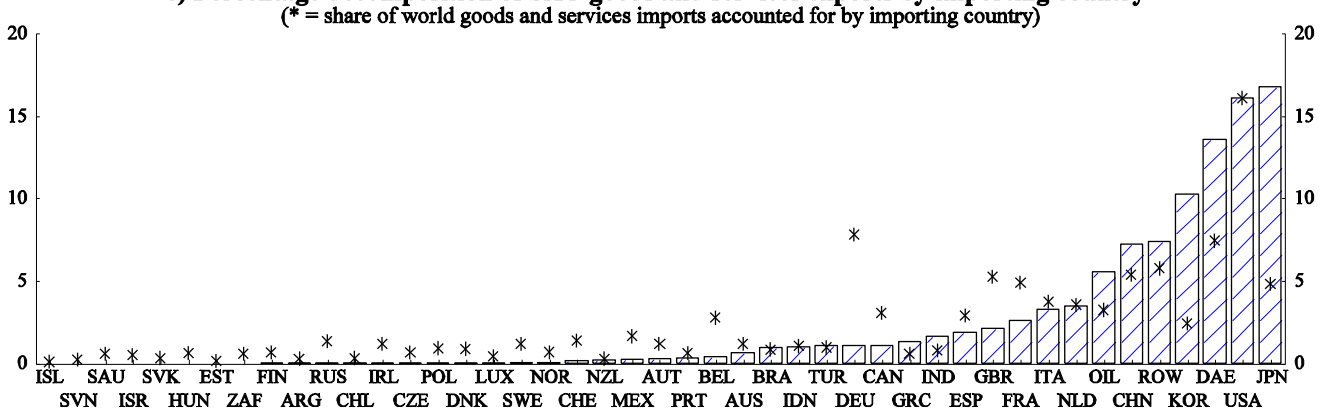

d) Share of each country's goods and services imports coming from SAU

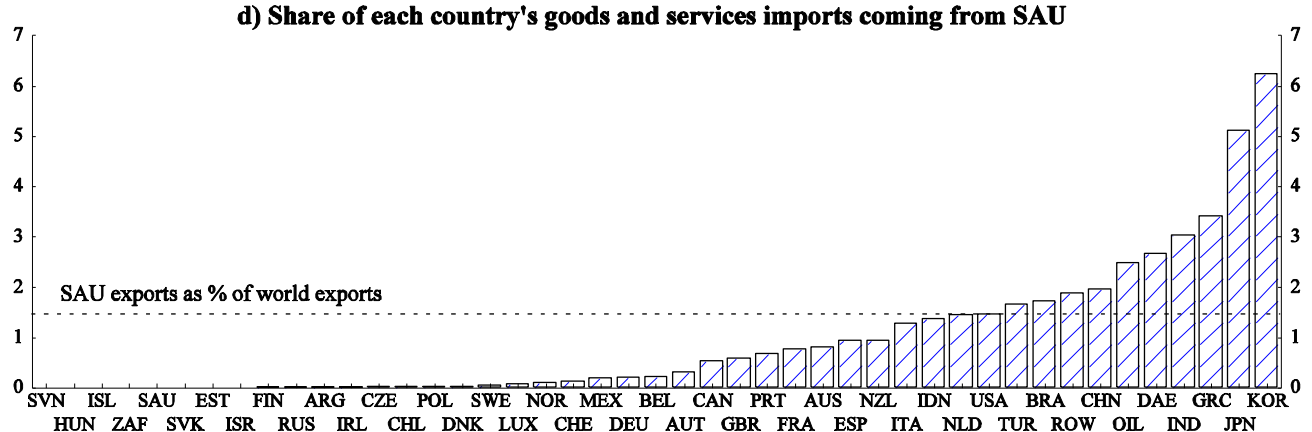


Figure 3.43. Geographical structure of goods and services trade of South Africa (ZAF)

a) Percentage decomposition of ZAF goods and services imports by exporting country

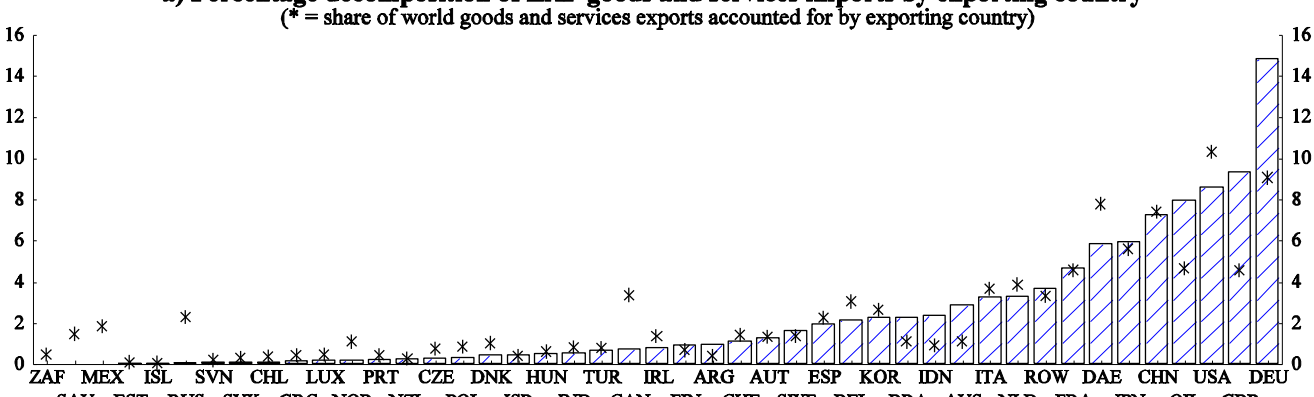

SAU EST RUS SVK GRC NOR NZL POL ISR IND CAN FIN CHE SWE BEL BRA AUS NLD FRA JPN OIL GBR

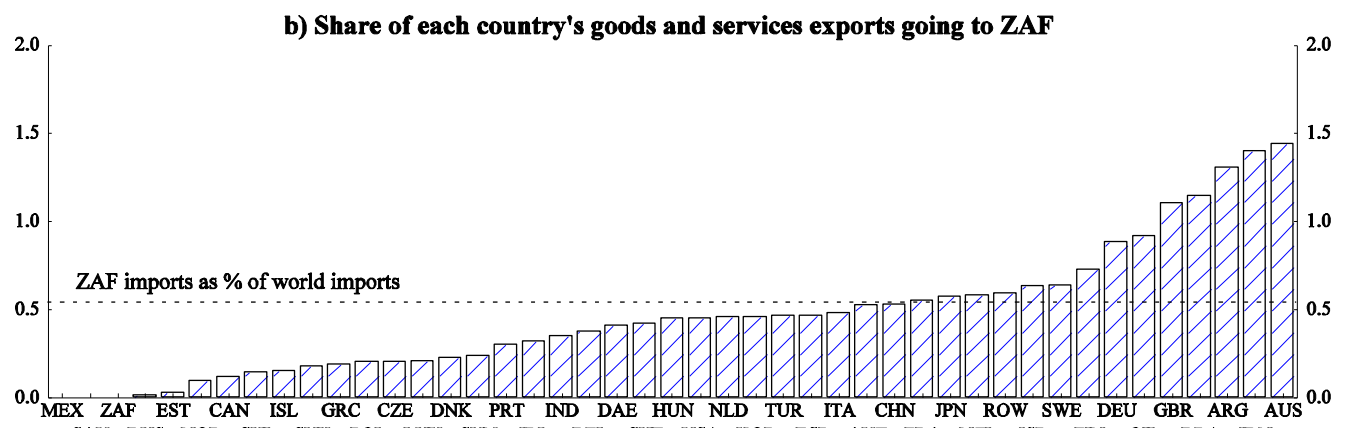

SAU RUS NOR CHL SVK POL LUX SVN IRL BEL CHE USA KOR ESP AUT FRA NZL ISR FIN OIL BRA IDN

c) Percentage decomposition of ZAF goods and services exports by importing country
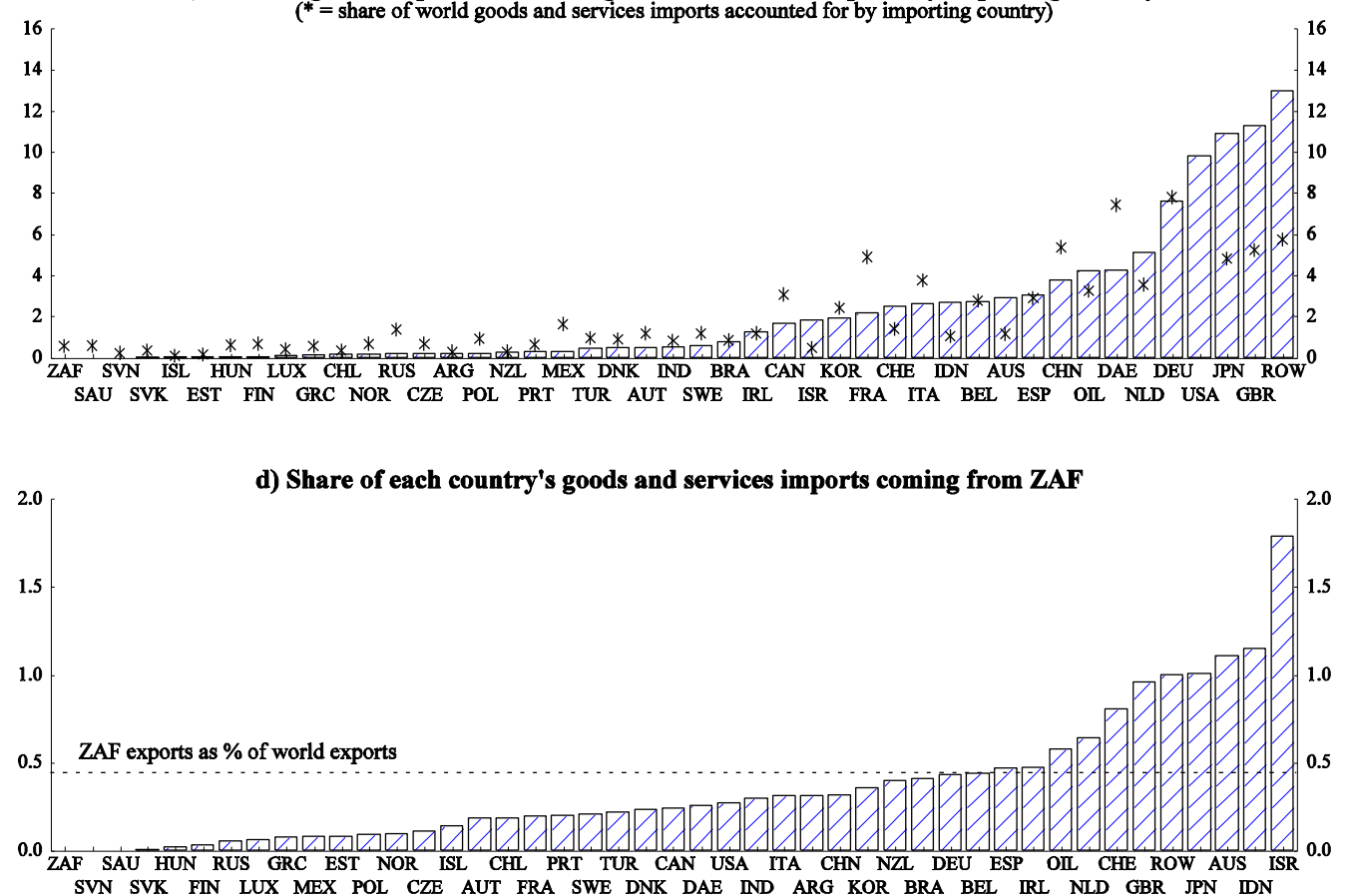
Figure 3.44. Geographical structure of goods and services trade of Dynamic Asia Economies (DAE) a) Percentage decomposition of DAE goods and services imports by exporting country

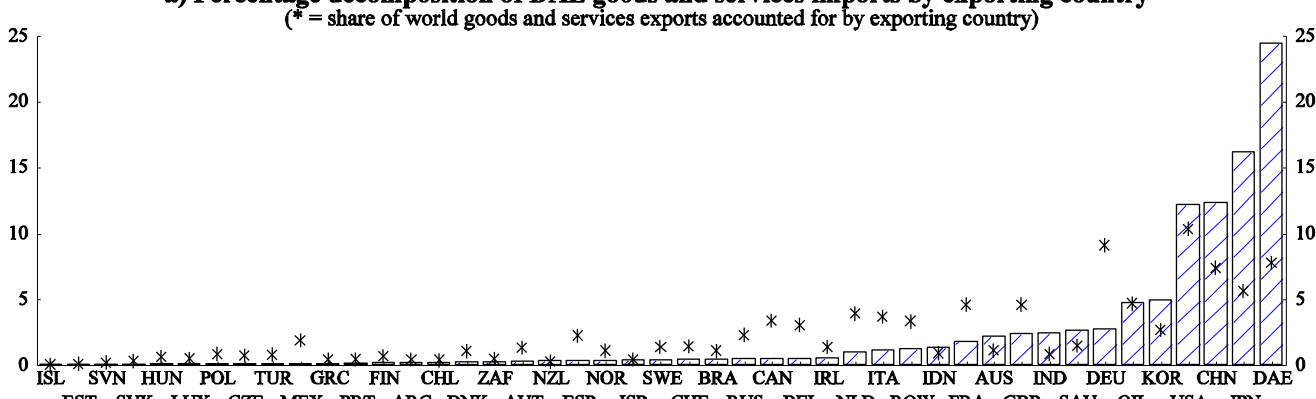
EST SVK LUX CZE MEX PRT ARG DNK AUT ESP ISR CHE RUS BEL NLD ROW FRA GBR SAU OIL USA JPN

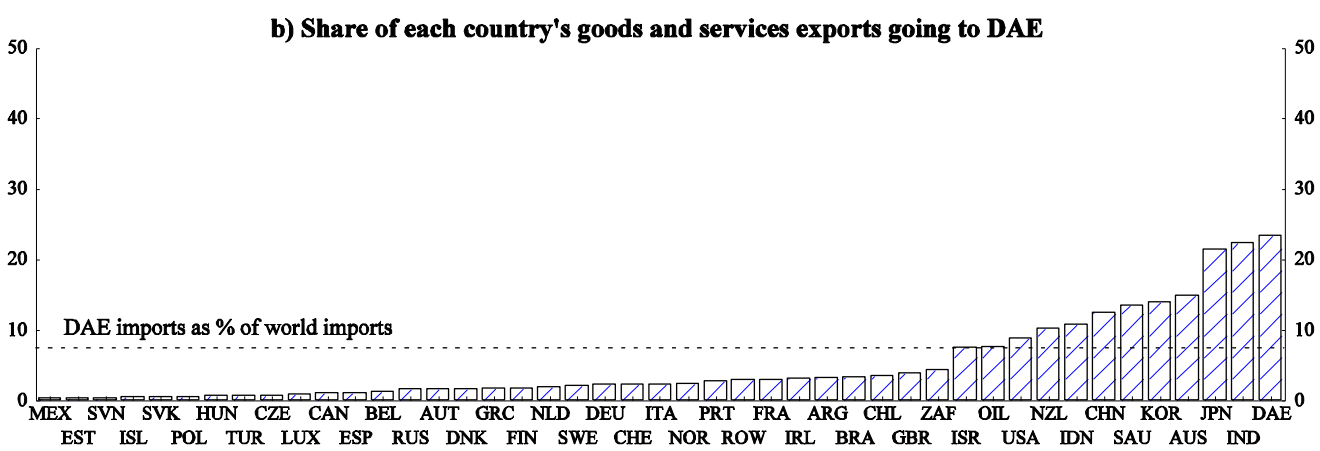

c) Percentage decomposition of DAE goods and services exports by importing country

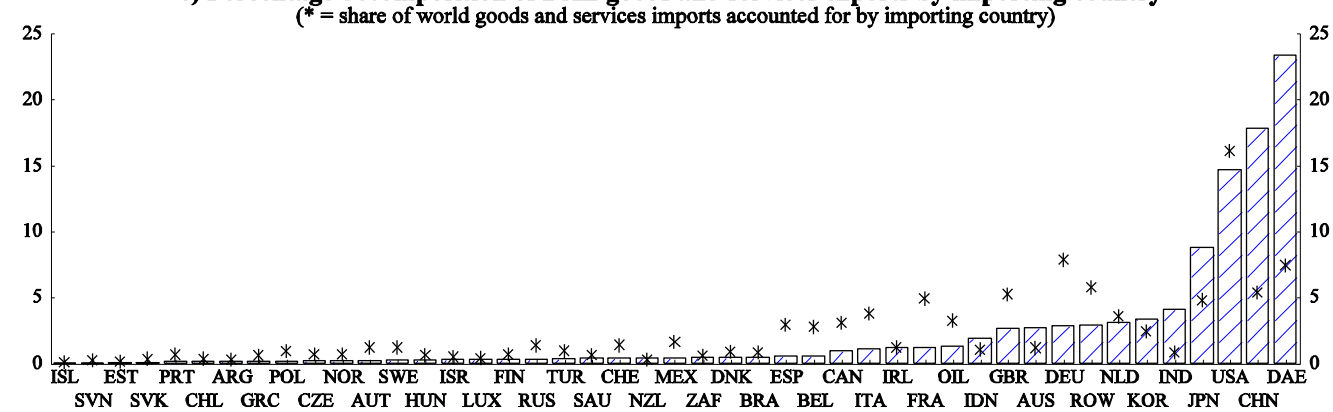

SVN SVK CHL GRC AZE AUT HUN LUX RUS SAU NZI ZAF

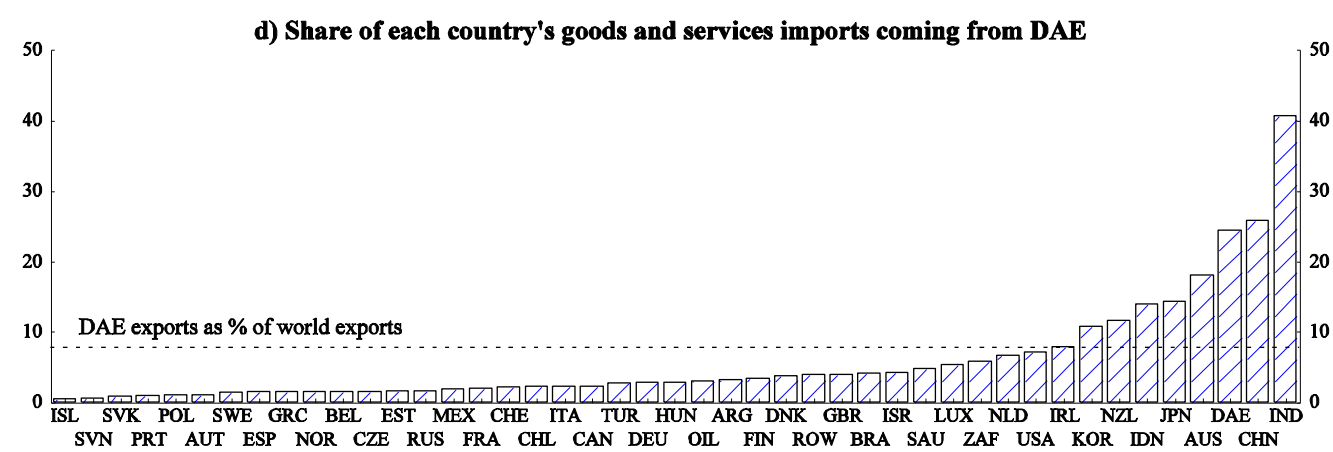


Figure 3.45. Geographical structure of goods and services trade of Oil producers (OIL)

a) Percentage decomposition of OIL goods and services imports by exporting country

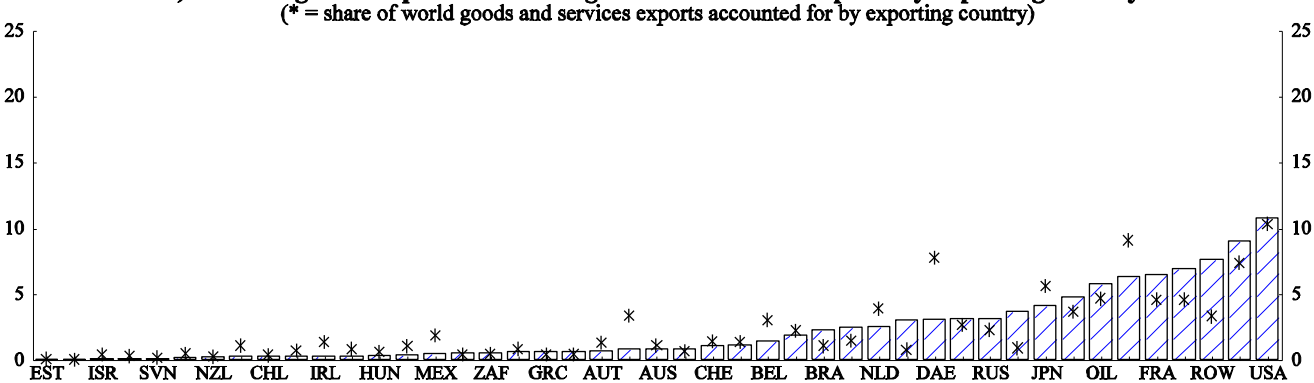

ISL SVK LUX NOR CZE POL DNK ARG IND PRT CAN FIN SWE ESP SAU TUR KOR IDN ITA DEU GBR CHN

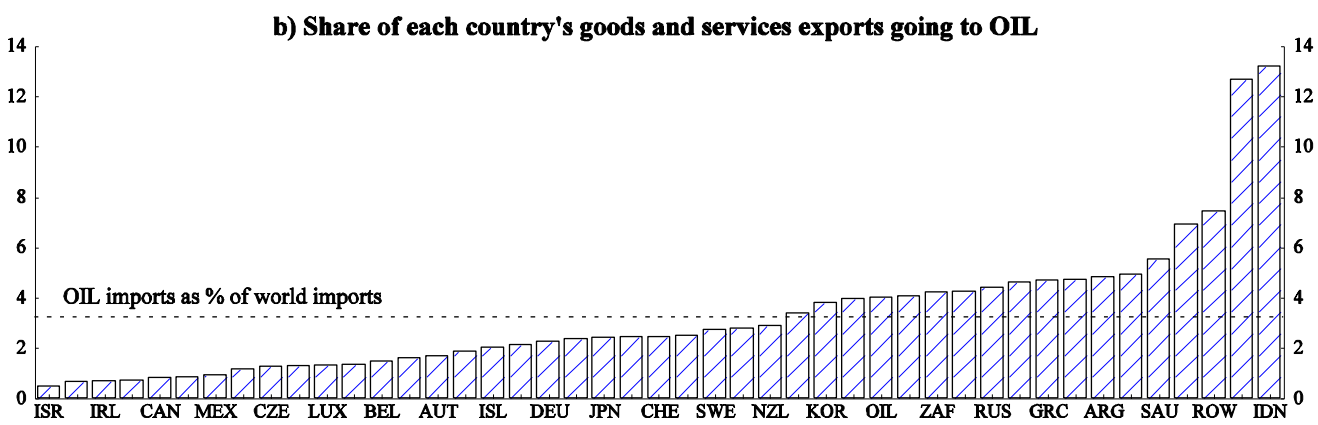
SVK EST NOR POL DAE DNK SVN HUN NLD IND CHL AUS ESP USA CHN FIN ITA FRA PRT GBR BRA TUR
SUT

c) Percentage decomposition of OIL goods and services exports by importing country
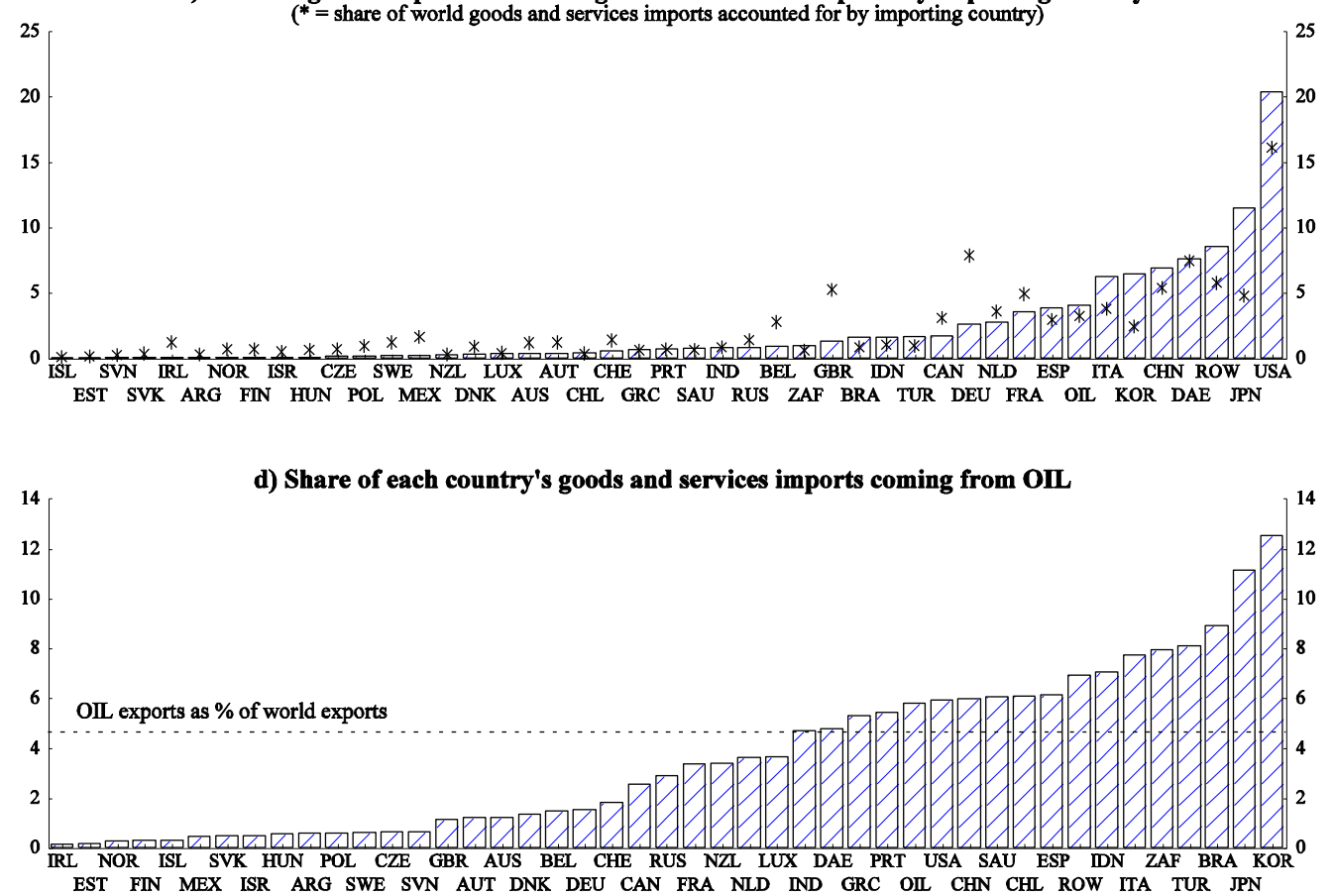
Figure 3.46. Geographical structure of goods and services trade of Remaining countries (ROW)

a) Percentage decomposition of ROW goods and services imports by exporting country

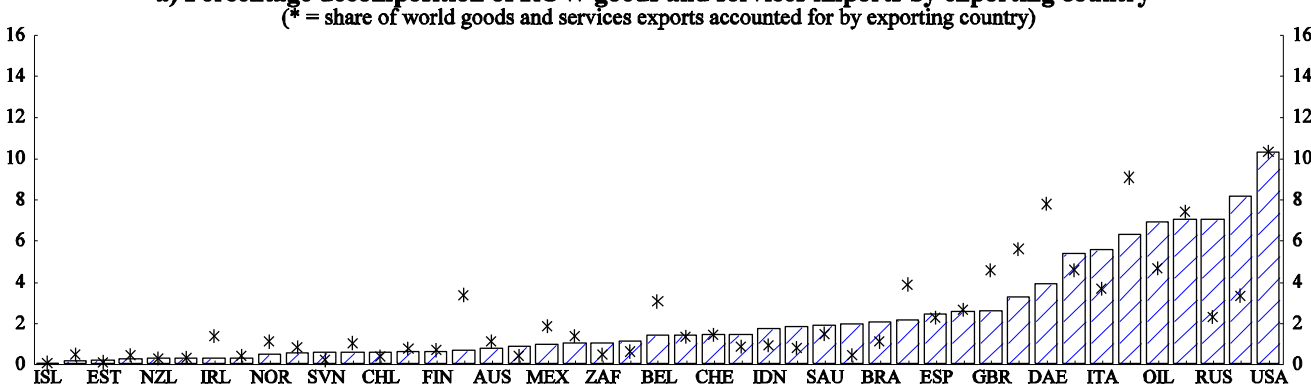

LUX PRT SVK ISR IND DNK CZE CAN ARG SWE HUN AUT POL TUR GRC NLD KOR JPN FRA DEU CHN ROW

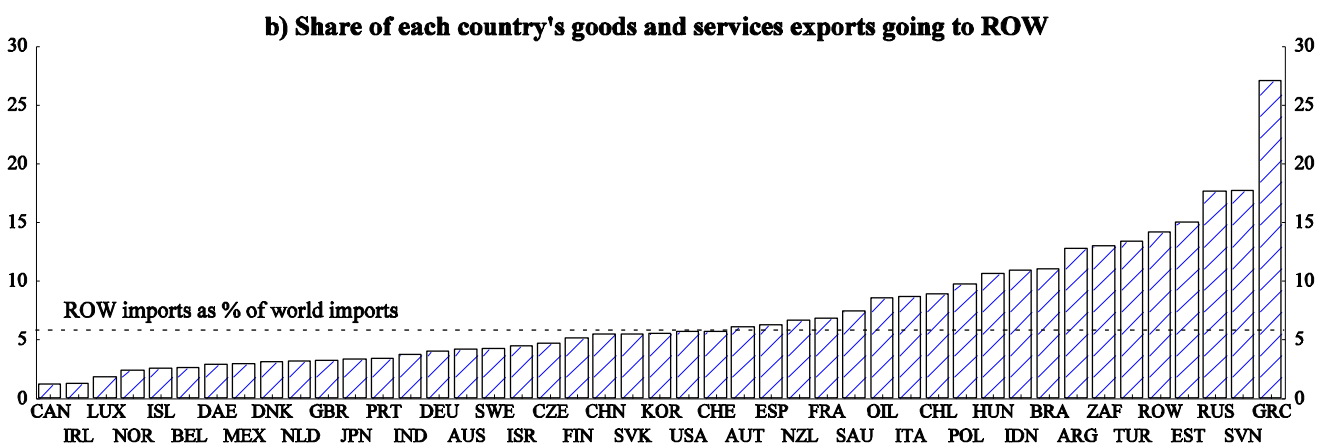

c) Percentage decomposition of ROW goods and services exports by importing country
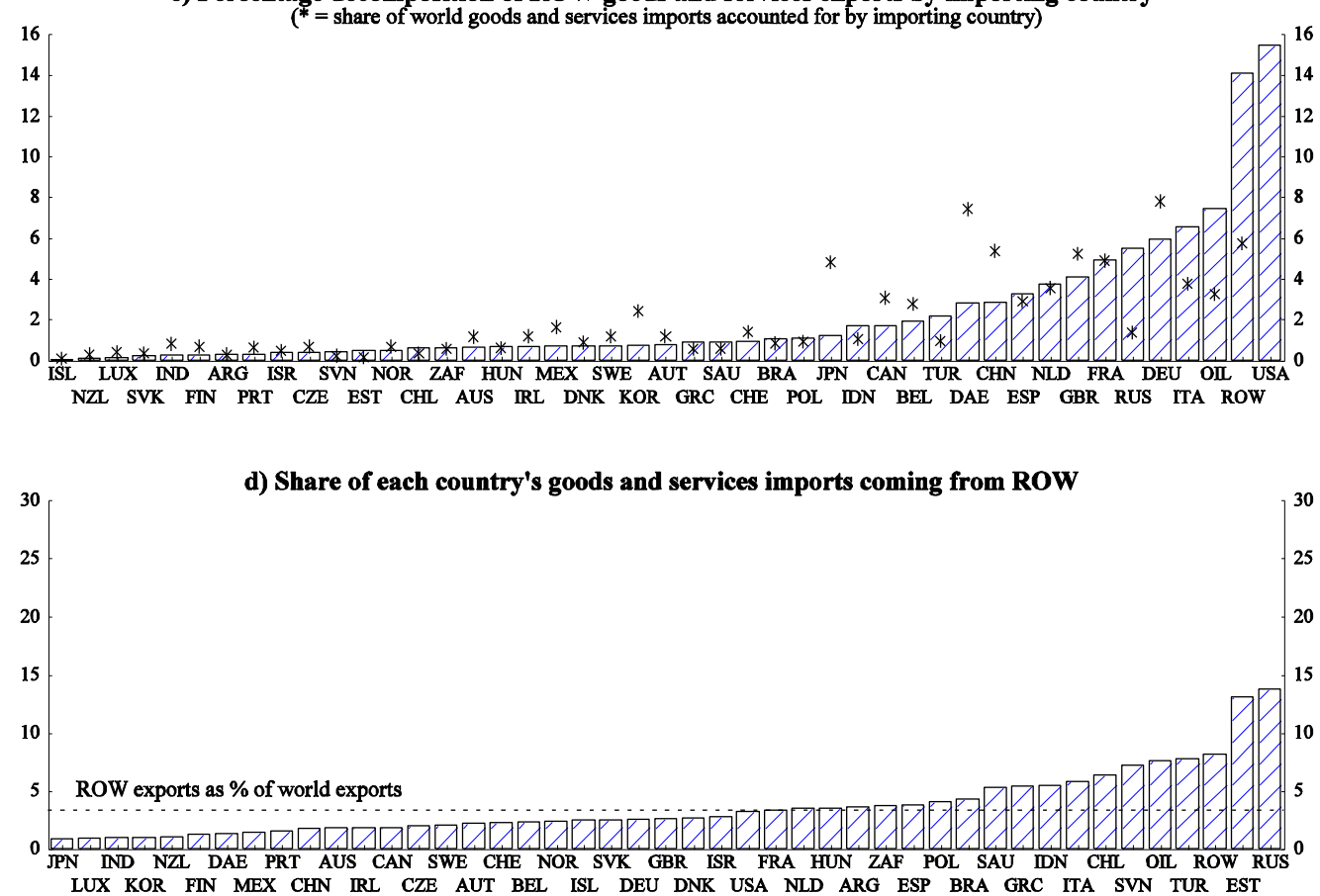


\section{BIBLIOGRAPHY}

Le Fouler L., W. Suyker and D. Turner (2001), "Trade linkages and the trade matrices in the OECD Interlink model”. OECD Economics Department Working Paper No.310.

Pain N., A. Mourougane, F. Sédillot and L. Le Fouler (2005), "Globalisation and Inflation in the OECD Economies", OECD Economics Department Working Paper No.440.

Wang Z., M. Gehlhar and Y. Shunli (2007), "Reconciling Trade Statistics from China, Hong Kong and Their Major Trading Partners -- A Mathematical Programming Approach", United States International Trade Commission, United States Department of Agriculture and China Center for Economic Research, Peking University; GTAP Technical Paper No.27, September. 


\section{ANNEX 1 KEY TO COUNTRY AND REGION ABBREVIATIONS USED IN FIGURES}

The OECD trade system covers all 33 OECD Member countries as well as nine non-OECD economies and three non-OECD economics areas.

OECD countries:

AUS Australia

AUT Austria

BEL Belgium

CAN Canada

CHL Chile

CZE Czech Republic

DNK Denmark

FIN Finland

FRA France

DEU Germany

GRC Greece

HUN Hungary

ISL Iceland

IRL Ireland

ISR Israel

KOR Korea

LUX Luxembourg

MEX Mexico

NLD Netherlands

NZL New Zealand

NOR Norway

POL Poland

PRT Portugal

SVK Slovak Republic

SVN Slovenia

ESP Spain

SWE Sweden

CHE Switzerland

TUR Turkey

ITA Italy

GBR United Kingdom

JPN Japan

USA United States

OECD regions:

OECD America: USA, CAN, MEX, CHL.

OECD Pacific: JPN, KOR, AUS, NZL.

OECD Euro area members, EA14: AUT, BEL, FIN, FRA, DEU, GRC, IRL, ITA, LUX, PRT, SVK, ESP, SVN.

OECD European Union members, EU20: EA14, CZE, DNK, HUN, POL, SWE, GBR

OECD Europe, EUR: EA20, ISL, NOR, CHE, TUR,

OECD30: countries that were members in 2000 : OCDE- CHL - SVN - ISR

Non OECD countries:

ARG Argentina

BRA Brazil

CHN China

EST Estonia

IND Indonesia

IDN India

RUS Russian Federation

SAU Saudi Arabia

ZAF South Africa 
Non-OECD regions:

DAE Dynamic Asian Economies: Chinese Taipei; Hong Kong, China; Malaysia; Philippines; Singapore; Thailand; Vietnam.

OIL Oil producers: Azerbaijan; Kazakhstan; Turkmenistan; Brunei; Timor-Leste; Bahrain; Iran; Iraq; Kuwait; Libya; Oman; Qatar; United Arab Emirates; Yemen; Ecuador; Trinidad and Tobago; Venezuela; Algeria; Angola; Chad; Rep of Congo.; Equatorial Guinea; Gabon; Nigeria; Sudan.

ROW: Rest of the world.

Total WLD World (Sum of OECD countries and non-OECD regions) 


\section{ANNEX 2 \\ THE CONSTRUCTION OF THE MATRICES}

\section{Building the goods matrix ${ }^{9}$}

Table A2.1 The goods trade matrix

\begin{tabular}{|c|c|c|c|c|c|c|c|c|c|c|}
\hline \multirow{2}{*}{ Exports $i$} & \multirow[t]{2}{*}{ Imports j } & \multicolumn{4}{|c|}{ OECD30 + China (imports) } & \multicolumn{4}{|c|}{ Chile, Israel ,Slovenia + Non OECD economies (imports) } & \multirow{2}{*}{$\begin{array}{l}\text { WORLD } \\
\text { exports }\end{array}$} \\
\hline & & 1 & $\ldots$ & 30 & 31 & 32 & $\ldots$ & 44 & 45 & \\
\hline \multirow{4}{*}{$\begin{array}{c}\text { OECD30 + } \\
\text { China } \\
\text { (exports) }\end{array}$} & 1 & 0 & & & & & & & & \multirow{4}{*}{$\begin{array}{c}\operatorname{Sum}(1, \mathrm{j}) \\
\ldots \\
\operatorname{Sum}(30, \mathrm{j}) \\
\operatorname{Sum}(31, \mathrm{j}) \\
\end{array}$} \\
\hline & & & 0 & & & & $X$ final $(i, j)$ & & & \\
\hline & 30 & & & 0 & & & & & & \\
\hline & 31 & & & & 0 & & & & & \\
\hline \multirow{4}{*}{$\begin{array}{c}\text { Chile, Isreal, } \\
\text { Slovenia + } \\
\text { Non-OECD } \\
\text { economies } \\
\text { (exports) }\end{array}$} & 32 & & & & & $\overline{0}$ & $X \_$Dyn $(i, j)$ & & & \multirow{3}{*}{$\begin{array}{c}\text { Sum(32,j) } \\
\ldots \\
\text { Sum(44,j) }\end{array}$} \\
\hline & $\ldots$ & & M final $(i, j)$ & & & $M \_$Dyn $(i, j)$ & 0 & & & \\
\hline & 44 & & & & & & & W_Dyn $(44,44)$ & & \\
\hline & 45 & & & & & & & & W_Dyn $(44,44)$ & $\operatorname{Sum}(45, j)$ \\
\hline \multicolumn{2}{|c|}{ WORLD imports } & Sum(i,1) & & Sum(i,30 & Sum(i,31) & \multicolumn{2}{|l|}{ Sum $(i, 32)$} & Sum(i,44) & Sum(i,45) & World trade \\
\hline
\end{tabular}

First an initial matrix of bilateral matrix of goods trade flows between the 45 economies is built. Then while the flows between the OECD30 countries and China do not require further adjustment, the other parts of the matrix involving Chile, Israel and Slovenia as well as the -OECD countries other than China has to be adjusted to ensure consistency at the world level. In particular, in the initial matrix the sum of reported values is not equal to the total goods trade by country.

A second step consists therefore in adjusting imports from OECD30 countries and China (lower left, $\mathrm{Ms}$ ) and exports to OECD30 and China (upper right, Xs) by the information on total trade flows and bilateral flows with the OECD30.

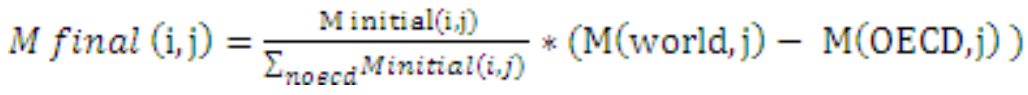

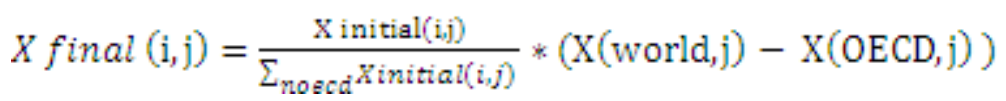

9. All the data come from DOTS statistics expect for Luxembourg where data are extracted from STATEC and Chinese Taipei where they come from the National Board of Trade's website (http://cus93.trade.gov.tw/english/FSCE/FSC0011E.ASP). For consistency reasons, trade with Puerto Rico and US Virgin Islands has been integrated to trade with United States, and similarly trade with Guadeloupe, Martinique, Reunion and French Guiana has been integrated to trade with France. Another issue comes from the fact that a few countries provide only data for Belgium-Luxembourg together (or similarly for the former Czechoslovakia) and not for individual countries separately. In this case, export flows from these countries are adjusted and replaced by mirror series using a $1.1 \mathrm{CIF} / \mathrm{FOB}$ correction factor. 
with X exports and M imports of country's (i) goods to country j .

For the lower right part of the matrix covering trade flows between non-OECD countries, Chile Israel and Slovenia, where there is no information of correct the bilateral level of imports or exports. The adjustment is based on the following calculations where the correction of the level is based on the import and export weights in the trade with the OECD30 and China.

$$
\begin{aligned}
& \text { Matrix } 4 \text { left: M_Dyn }(\mathrm{i}, \mathrm{j})=\frac{\text { M initial[ij] }}{\sum_{\text {go OECD+china }} \text { Minitial(i,j) }} \sum_{30 \text { oECD+china }} \operatorname{Mfinal}(i, j)
\end{aligned}
$$

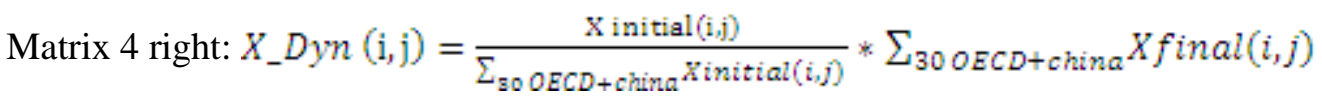

For zones, where there are intra-trade flows the diagonal is defined as:

$$
\text { Matrix } 4 \text { diagonal: } W_{-} \text {Dyn }(\mathrm{i}, \mathrm{j})=\frac{\text { Trade initial(i,j) }}{\text { World trade initial }(i, j)} \text { World Tradefinal( }(i, j)
$$

With this method based on the exports' weights on one hand and the imports' weights on the other hand, trade flows between non-OECD countries, Chile Israel and Slovenia are underestimated. Each coefficient in this matrix is therefore adjusted dynamically until the trade flows in the matrix are equal to the observed total (this requires three iterations).

\section{Building the service matrix}

Again, OECD30 countries are treated differently from Chile, Israel and Slovenia where coverage in Statistics on International Trade in Services is still limited.

\section{Estimations of missing data for the OECD30 sub-matrix}

Even for trade between OECD countries, the initial matrix derived from the OECD Statistics on International Trade in Services is not complete. Missing values are estimated on the basis of the weight of the 2005 goods matrix. Let's denote $\alpha_{O E C D}^{G 00 d}(i, j)$ the share of country's $(i)$ goods export to country $\mathrm{j}$ relative to its total export to OECD30 countries. In the simple example below, the export of services from country 3 to country 5 is estimated the following way:

\begin{tabular}{|c|c|c|c|c|c|c|c|c|c|c|}
\hline \multirow[b]{2}{*}{ Exports } & \multirow[t]{2}{*}{ Imports } & \multicolumn{5}{|c|}{ OECD30 (imports) } & \multicolumn{4}{|c|}{ Non OECD30 (imports) } \\
\hline & & 1 & 2 & 3 & 4 & 5 & 6 & 7 & 8 & 9 \\
\hline \multirow{5}{*}{$\begin{array}{l}\text { OECD30 } \\
\text { (exports) }\end{array}$} & 1 & 0 & & & $X(1,4)$ & & & & & \\
\hline & 2 & & 0 & & $X(2,4)$ & & & & & \\
\hline & 3 & $X(3,1)$ & $X(3,2)$ & 0 & $X(3,4)$ & $?$ & & & & \\
\hline & 4 & & & & 0 & & & & & \\
\hline & 5 & & & & $X(5,4)$ & 0 & & & & \\
\hline \multirow{4}{*}{$\begin{array}{l}\text { Non-OECD30 } \\
\text { (exports) }\end{array}$} & 6 & & & & & & & & & \\
\hline & 7 & & & & & & & & & \\
\hline & 8 & & & & & & & & & \\
\hline & 9 & & & & & & & & & \\
\hline
\end{tabular}

$$
X(3,5)=\frac{\alpha_{O E C D B O}^{G O O d s}(3,5)}{1-\alpha_{O O E C D 30}^{G o d s}(3,5)} \sum_{j \neq 5} X(3, j)
$$




\section{Adjustment of the total OECD30 trade}

For a few countries, in particular where financial services play an important role, there is a large discrepancy between the sum of bilateral trade flows with OECD30 countries and the total exports or imports obtained from the MEI database (for Switzerland for instance, this sum was more than twice total Swiss exports of services). In this case, a correction has been made when the partial sum of exports/imports to OECD30 countries exceeded 95\% of total exports (respectively imports) of the country. The option retained is to adjust the trade to OECD30 countries (export or import) of the problematic country to the total services trade given by the MEI database, by using the relative share of goods exports (respectively imports) in the OECD30 zone as a whole. More precisely, assuming that in the matrix above, the sum of bilateral imports from the country (4) are overestimating total imports of this country, the column of the OECD30 sub-matrix corresponding to this country is corrected the following way

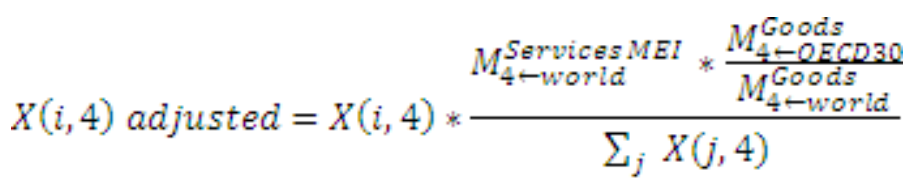

Where $M_{4 \text {-world }}^{M E I}$ is total import of services of country (4) from the world obtained from the MEI database, $M_{4-O E E C D 30}^{G 00 d \mathrm{~B}}$ is the total import of goods of country (4) from OECD30 countries in the 2005 goods matrix and $M_{4-\text { world }}^{G o 0 d s}$ is the total import of goods of country (4) (in the 2005 goods matrix).

\section{Calculation of services exports/imports between OECD30 and non OECD30 countries and zones}

For non-OECD30 countries and zones, the overall information on service trade is relatively limited (except for China where a relative complete set of mirror series can be used). Data on aggregate services trade from MEI allows however to first deduct the total exports of OECD30 countries to non-OECD30 countries (B in the matrix below), and the total OECD imports from non-OECD countries ( $\mathrm{C}$ in the matrix below).

\begin{tabular}{|c|c|c|c|c|c|c|c|c|c|c|c|}
\hline \multirow{2}{*}{ Exports } & \multirow[t]{2}{*}{ Imports } & \multicolumn{5}{|c|}{ OECD } & \multicolumn{4}{|c|}{ Non OECD zones } & \multirow{2}{*}{ MEI total } \\
\hline & & 1 & 2 & 3 & 4 & 5 & China & 7 & 8 & 9 & \\
\hline \multirow[t]{5}{*}{ OECD } & 1 & \multirow{5}{*}{\multicolumn{5}{|c|}{ A }} & \multirow{5}{*}{\multicolumn{4}{|c|}{ 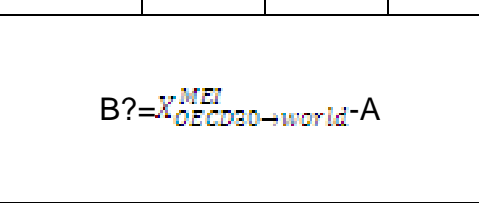 }} & \multirow{5}{*}{ 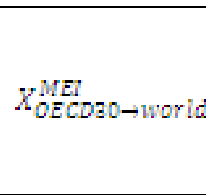 } \\
\hline & 2 & & & & & & & & & & \\
\hline & 2 & & & & & & & & & & \\
\hline & 4 & & & & & & & & & & \\
\hline & 5 & & & & & & & & & & \\
\hline \multirow{4}{*}{$\begin{array}{l}\text { Non- } \\
\text { OECD } \\
\text { zones }\end{array}$} & China & \multirow{4}{*}{\multicolumn{5}{|c|}{ 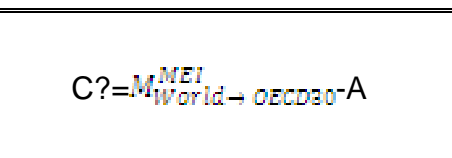 }} & & & & & \\
\hline & 7 & & & & & & & & \multirow{3}{*}{\multicolumn{2}{|c|}{$D=?$}} & \\
\hline & 8 & & & & & & & & & & \\
\hline & 9 & & & & & & & & & & \\
\hline \multicolumn{2}{|c|}{ MEI total } & \multicolumn{5}{|c|}{$M_{\text {WOVId } \rightarrow \text { OECDRO }}^{M A E I}$} & & & & & \\
\hline
\end{tabular}

In a second stage, the rows and columns of the sub-matrices $\mathrm{B}$ and $\mathrm{C}$ are completed, again using total export/import values from MEI and, also, the weight from the previous 2000 services matrix. For example, exports of the OECD country (i) to non-OECD country (j) (noted B(i,j)) are completed the following way: 


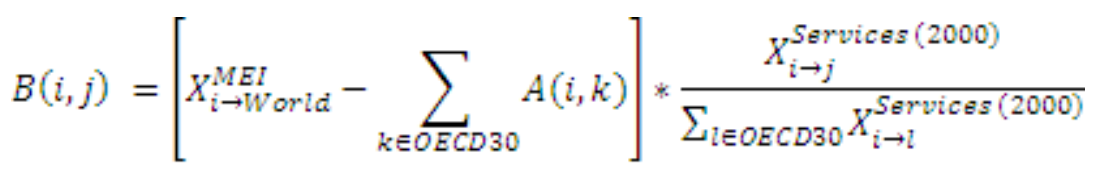

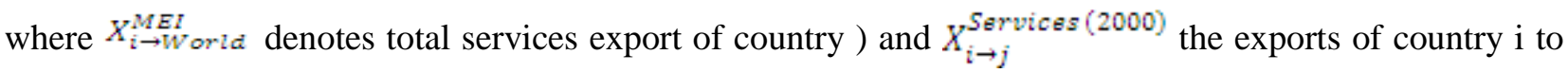
country $\mathrm{j}$ in the 2000 trade matrix.

For China, the same procedure is applied. Values for its total export and import of services are drawn from the IMF Balance of Payment database and the bilateral trade with OECD countries from OECD Statistics on International Trade in Services data. Before that procedure was applied, missing values were completed according to the same methodology as described above for OECD members. In this particular case, weights from the 2000 services matrix were used in order to avoid large distortions linked to the dramatic changes in merchandise trade for this country.

\section{Computation of bilateral trade between non-OECD countries, Chile, Israel and Slovenia}

For intra non-OECD30 countries bilateral trade flows, only limited information is available and therefore the total non-OECD30 intra-trade (excluding China) needs first to be estimated. This estimation is carried out by using the ratio of services trade to goods trade calculated for a subset of non OECD countries (for which such variables were available in the IMF Balance of Payments database). This ratio multiplied by the non-OECD intra-trade in the 2005 goods matrix is taken as the estimated value for the sub-matrix (D) above. In a second stage, each cell is completed using the bilateral weights of the corresponding goods sub-matrix. 
ECO/WKP(2010)67

ANNEX 3

DETAILS ON THE EVOLUTION OF TRADE PARTNERS 
Figure A3.1 United States export breakdown by destination

Share in 2005 United States exports (\%)
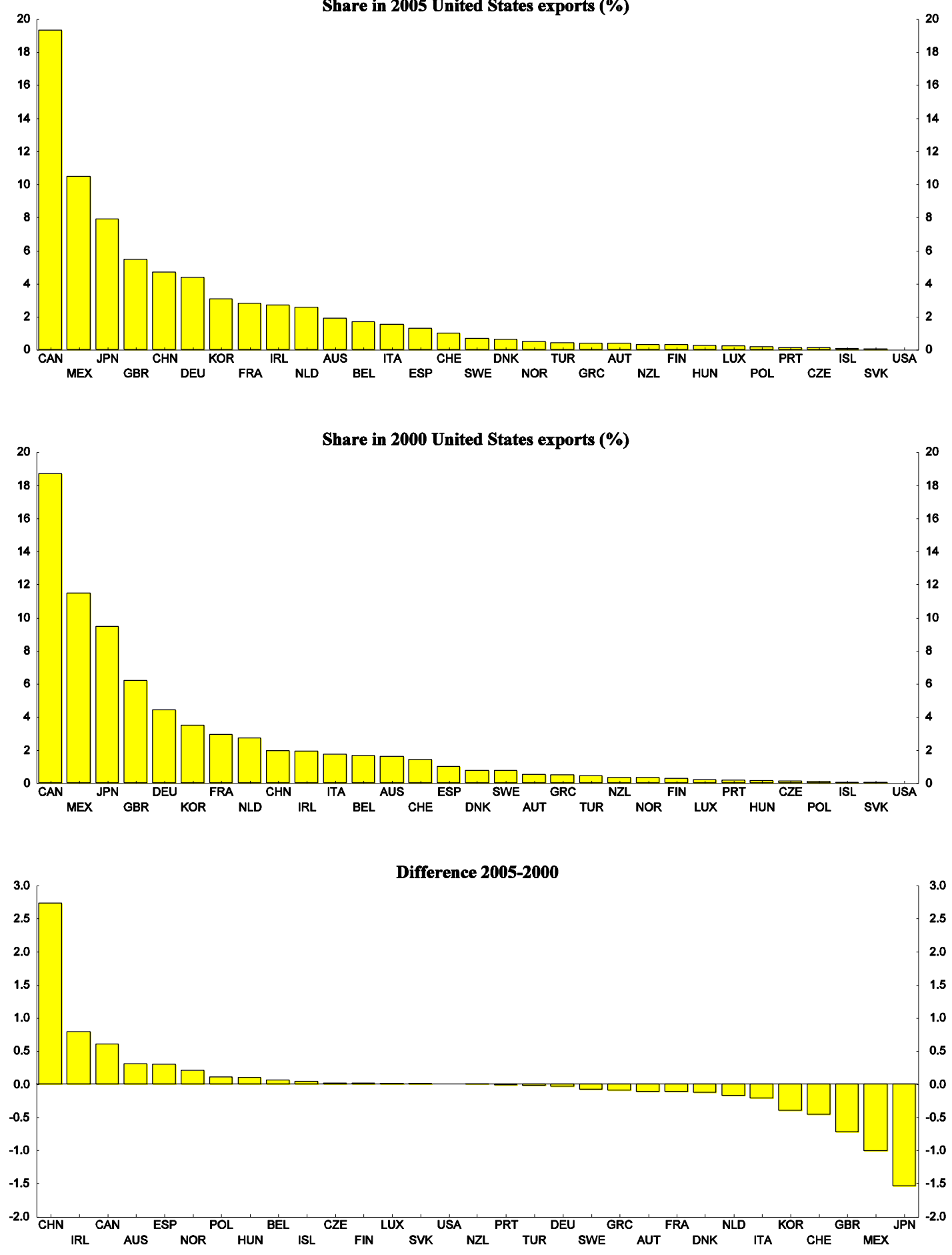
Figure A3.2 United States import breakdown by origin
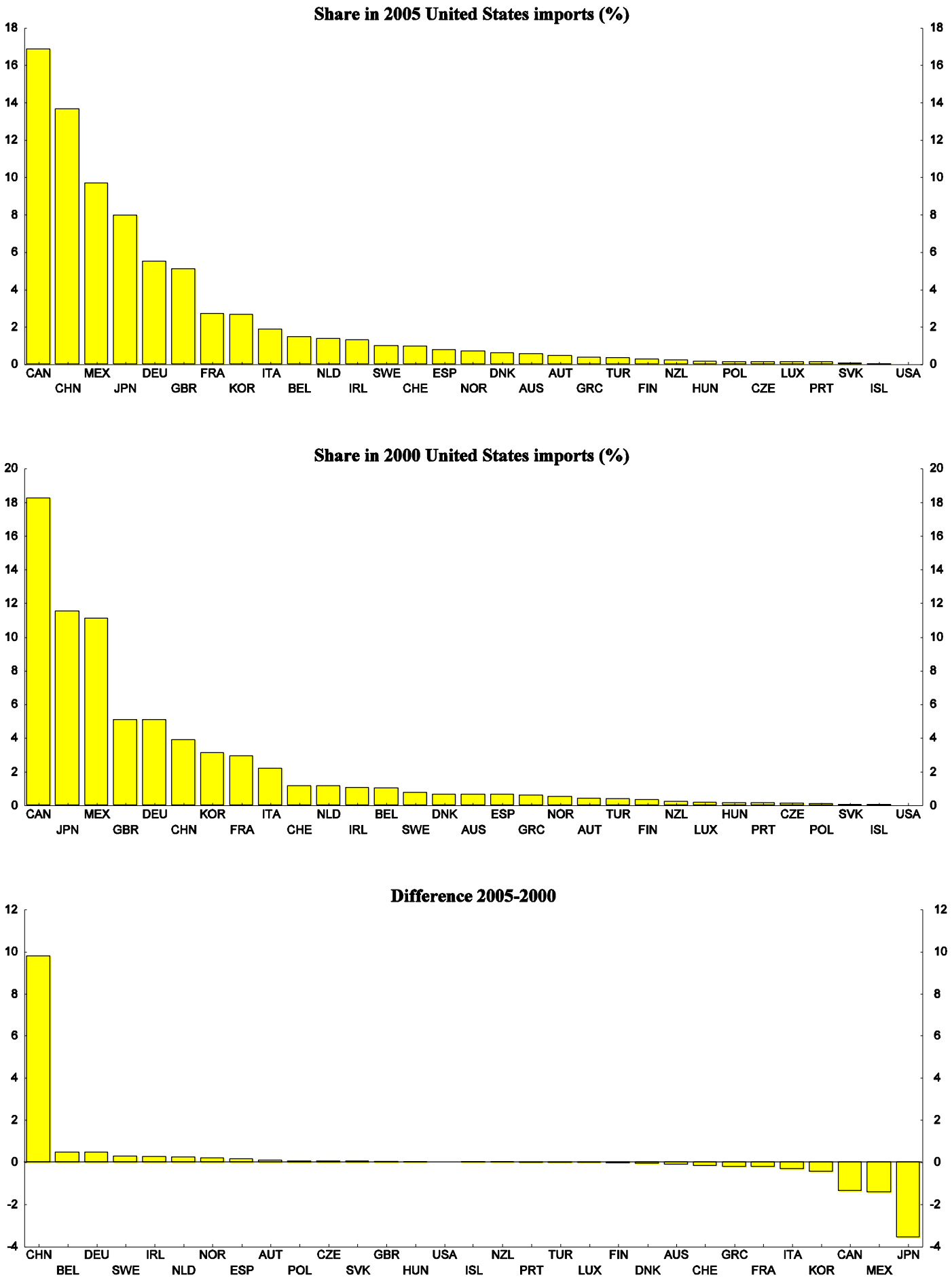
Figure A3.3 Japan export breakdown by destination
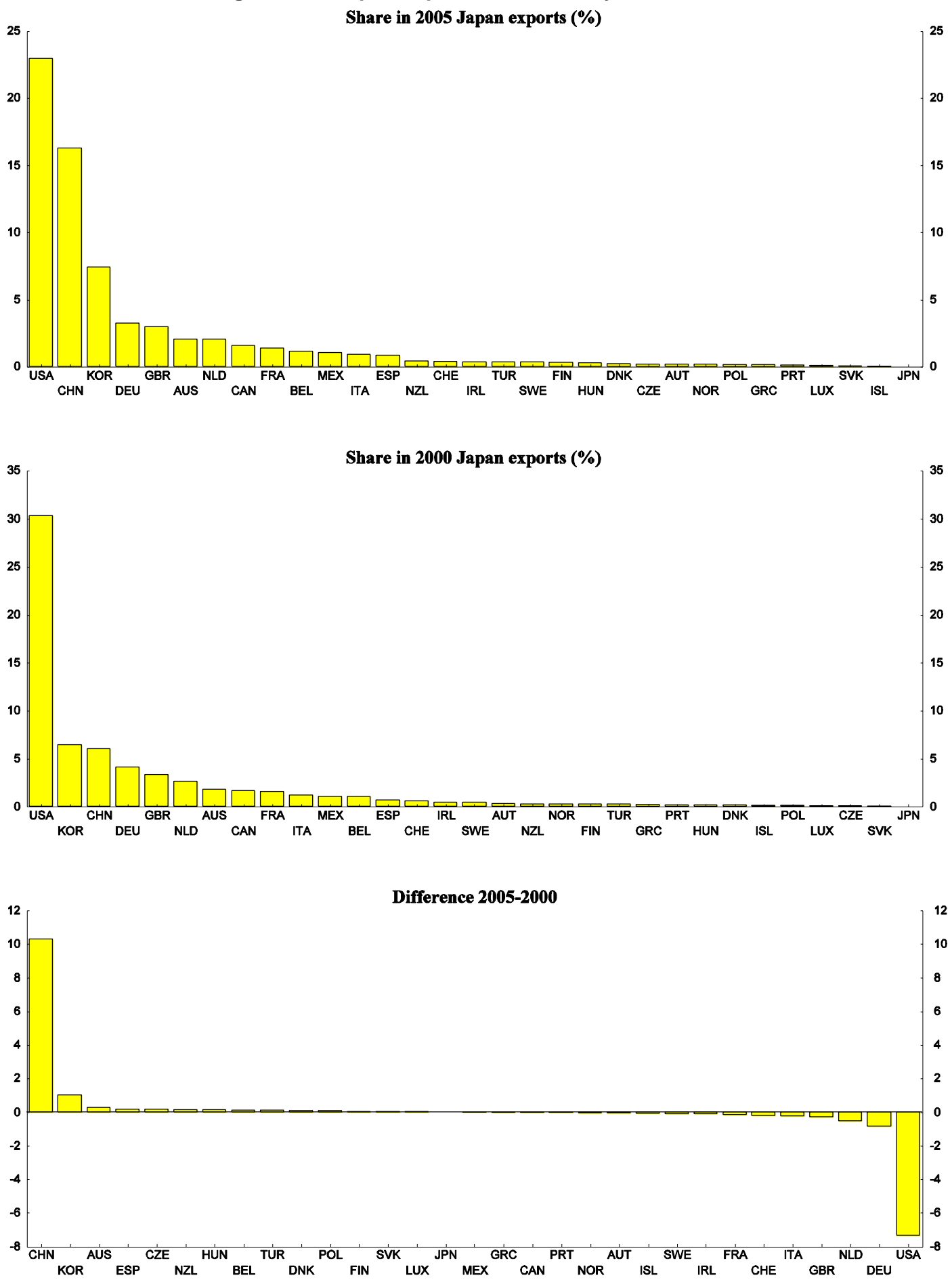
Figure A3.4 Japan import breakdown by origin

Share in 2005 Japan imports (\%)
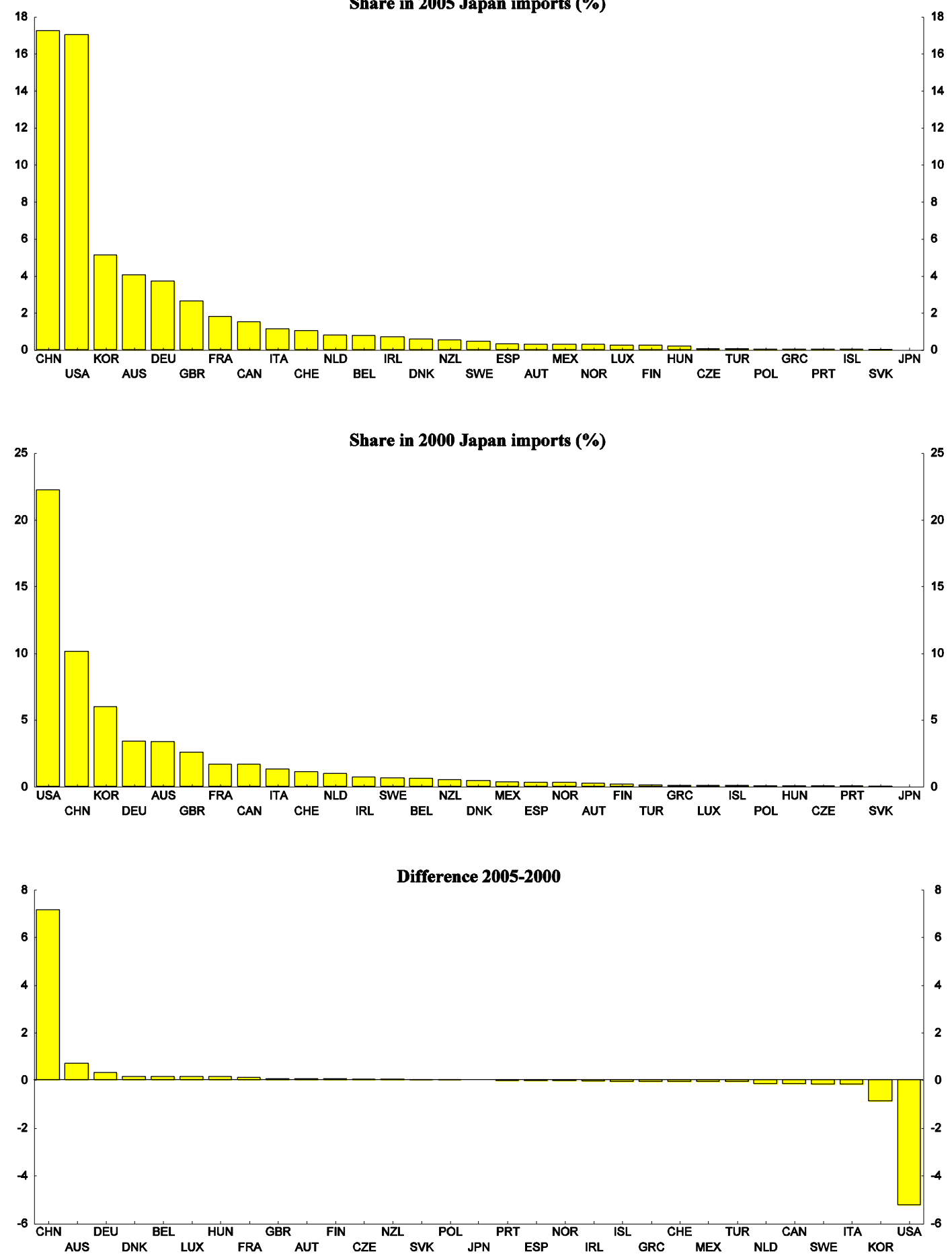
Figure A3.5 Canada export breakdown by destination
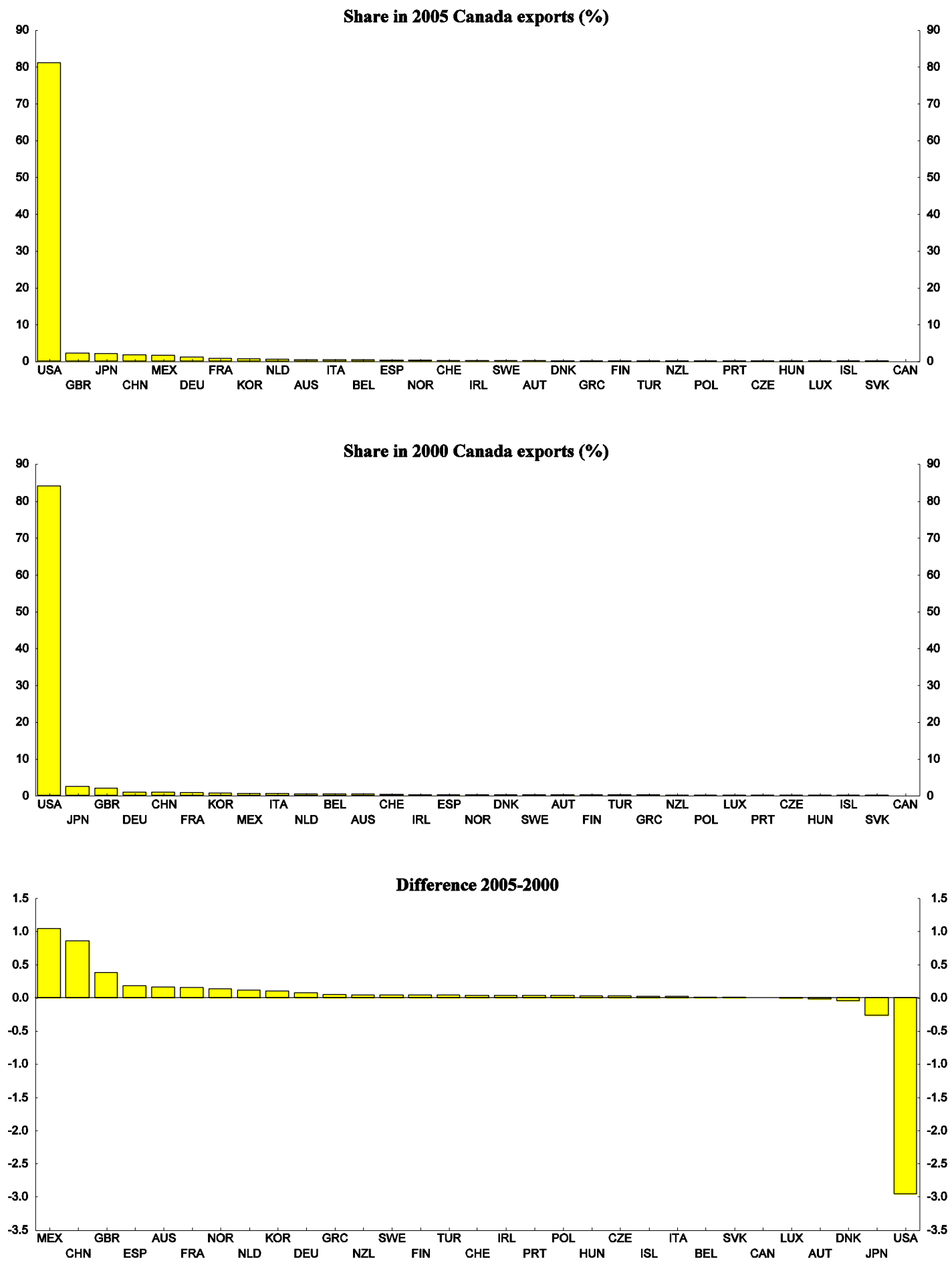
Figure A3.6 Canada import breakdown by origin
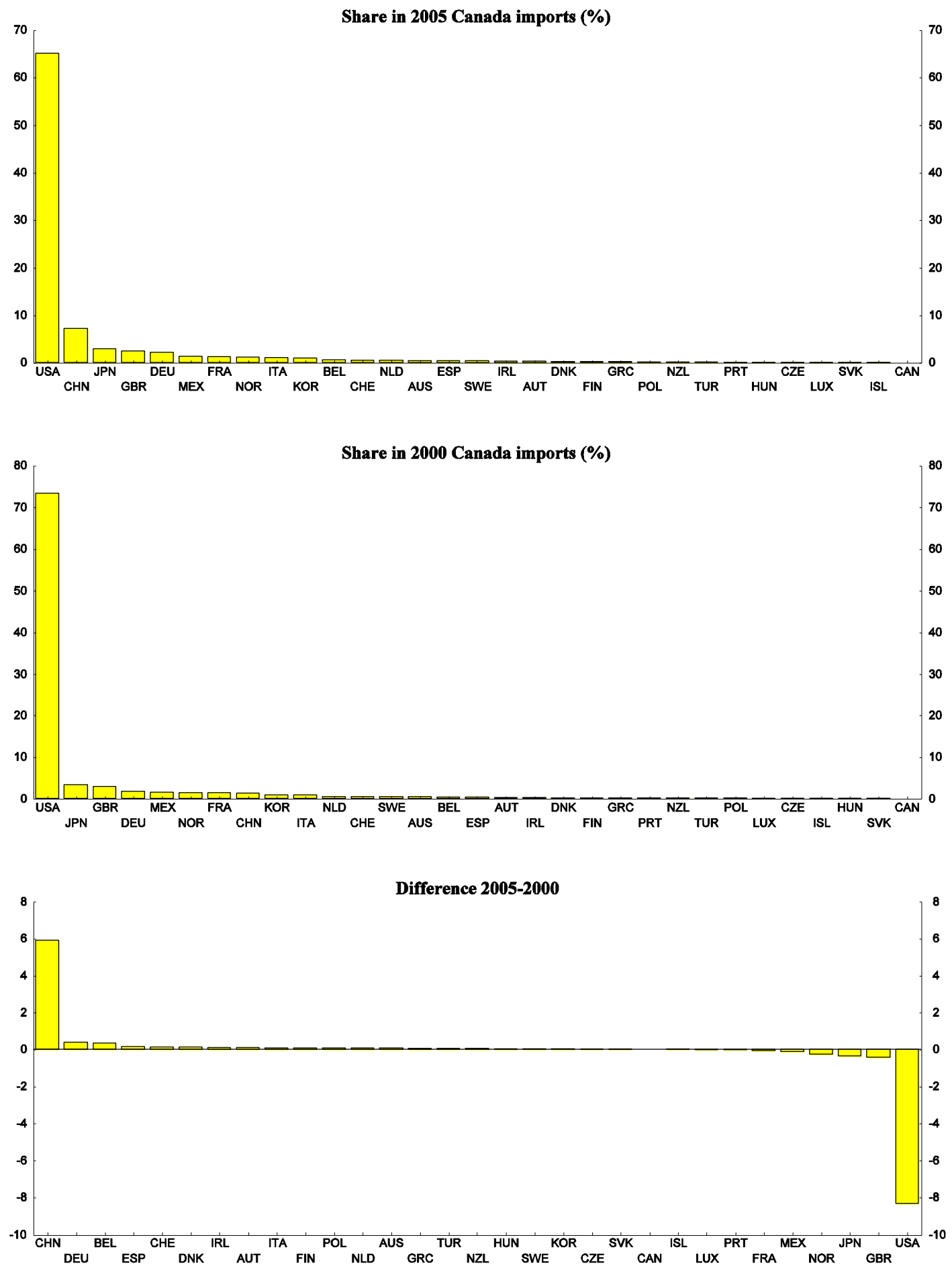
Figure A3.7 Germany export breakdown by destination
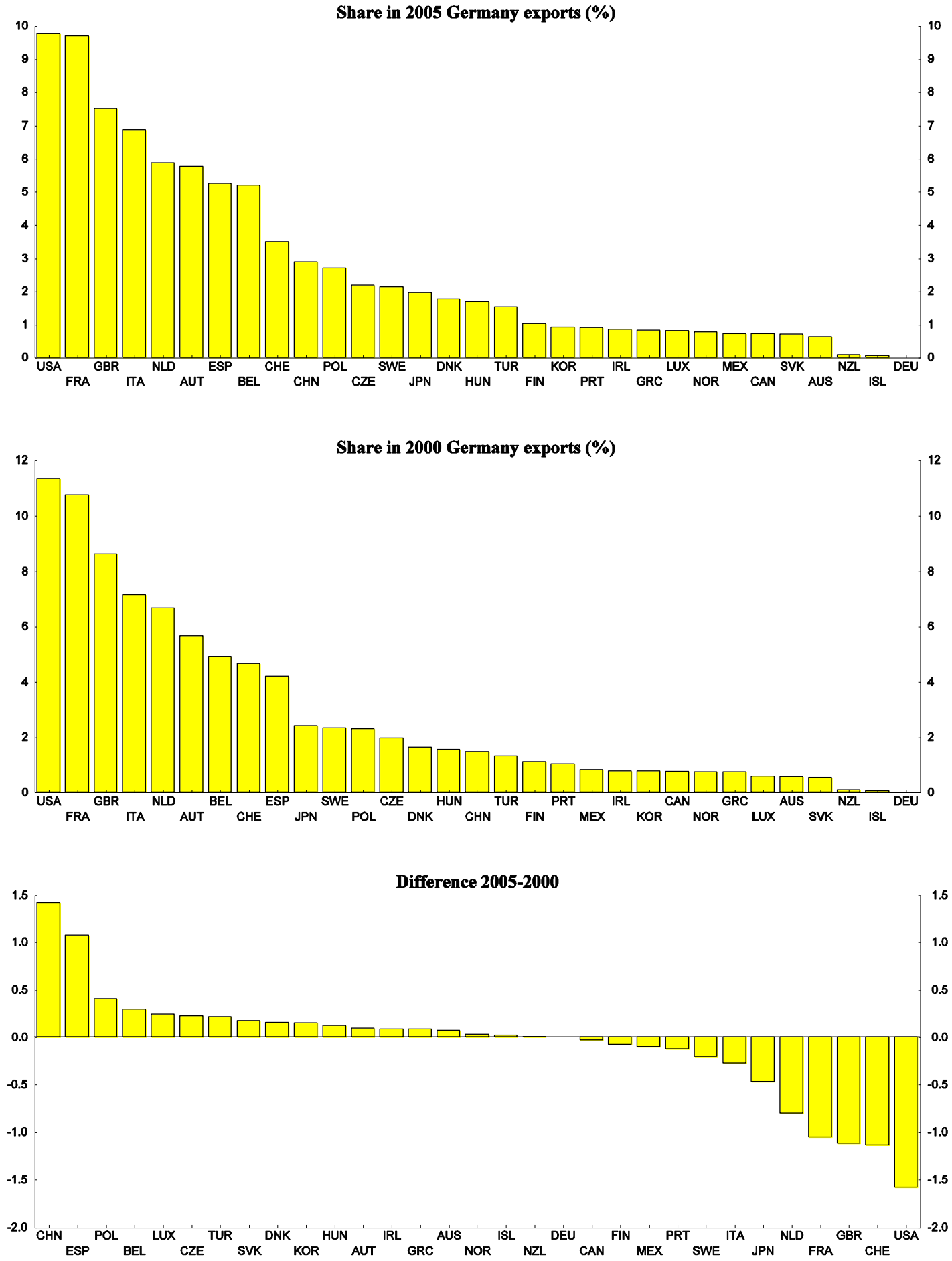
Figure A3.8 Germany import breakdown by origin
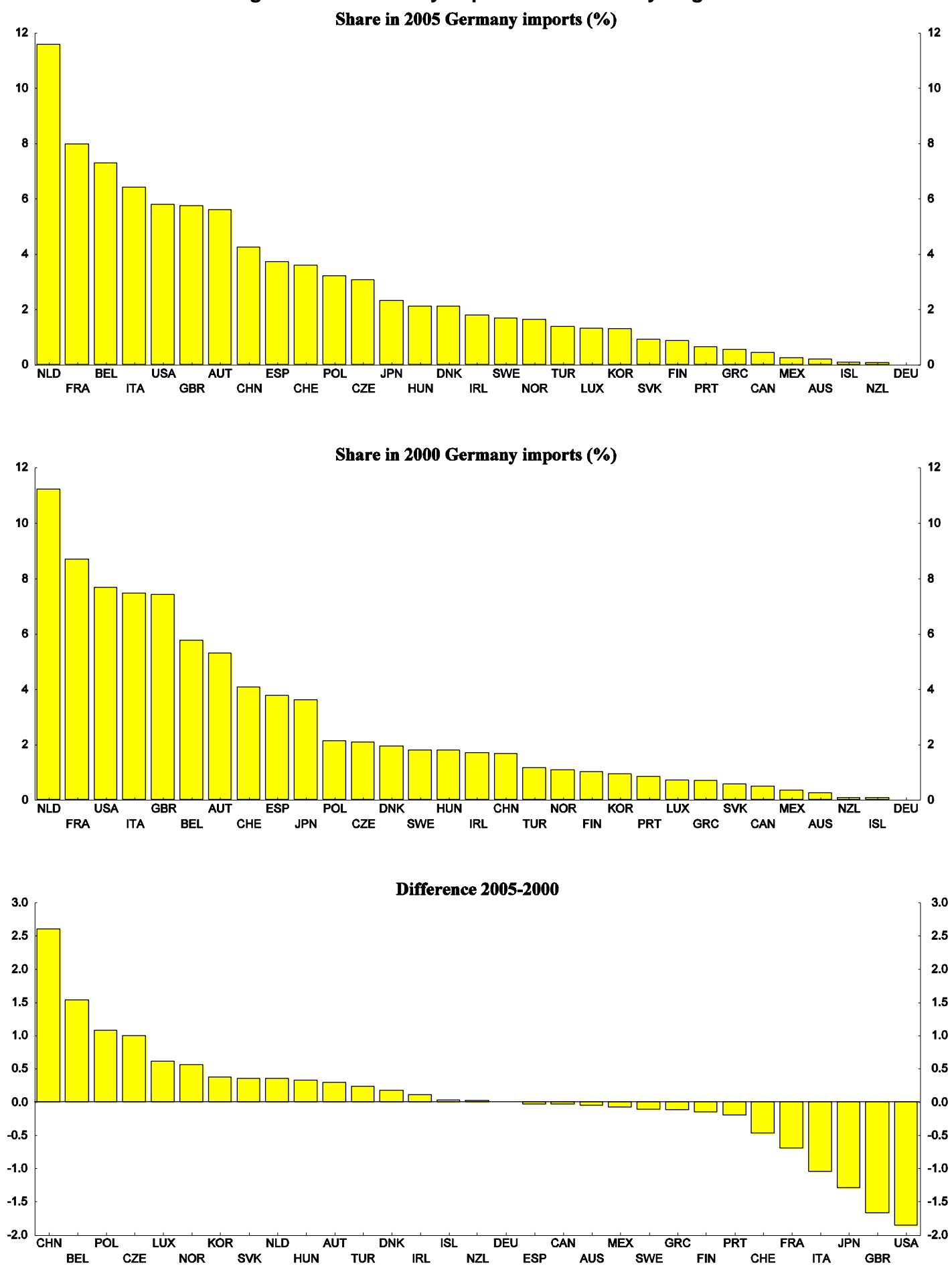
Figure A3.9 France export breakdown by destination
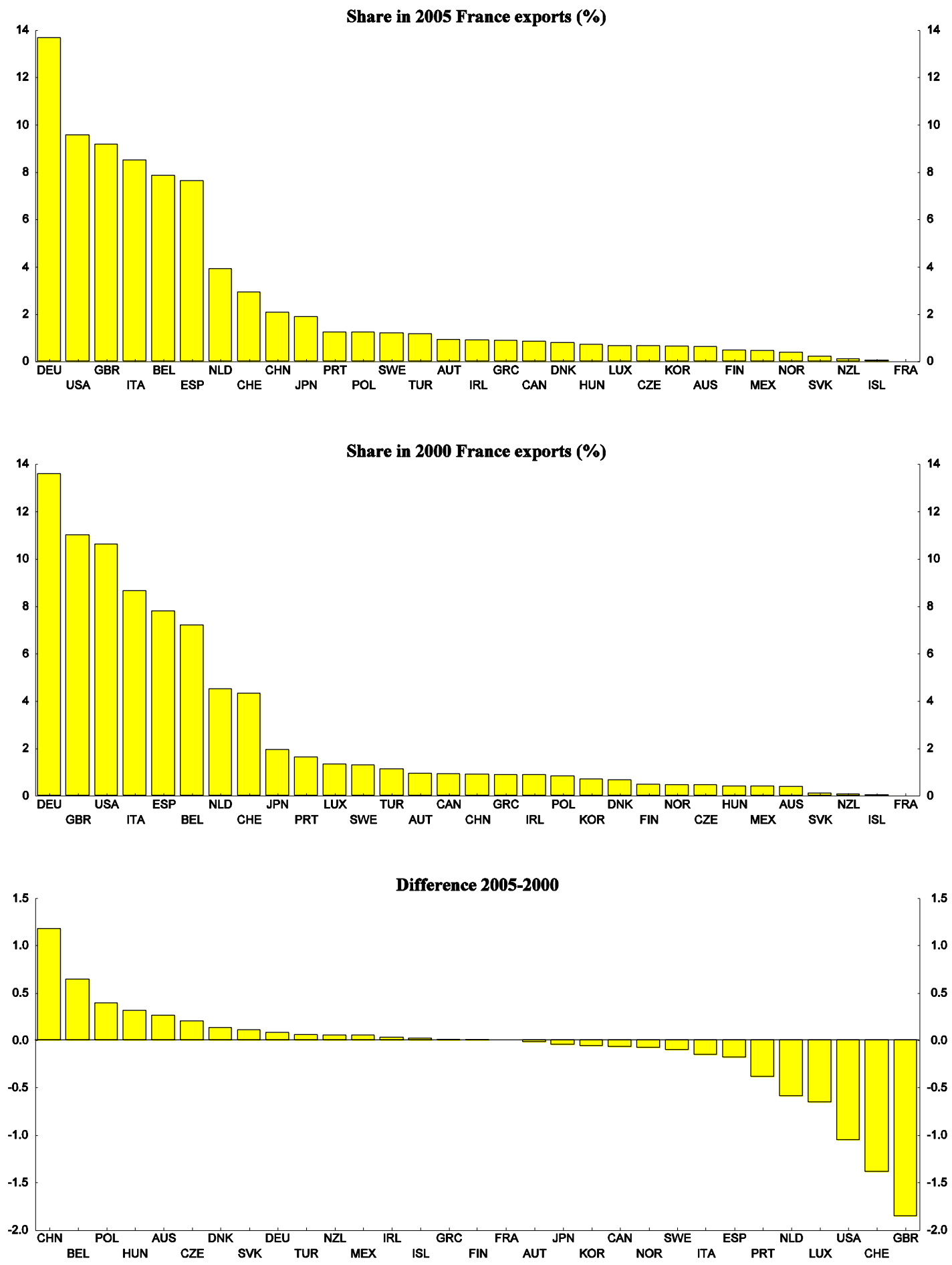
Figure A3.10 France import breakdown by origin
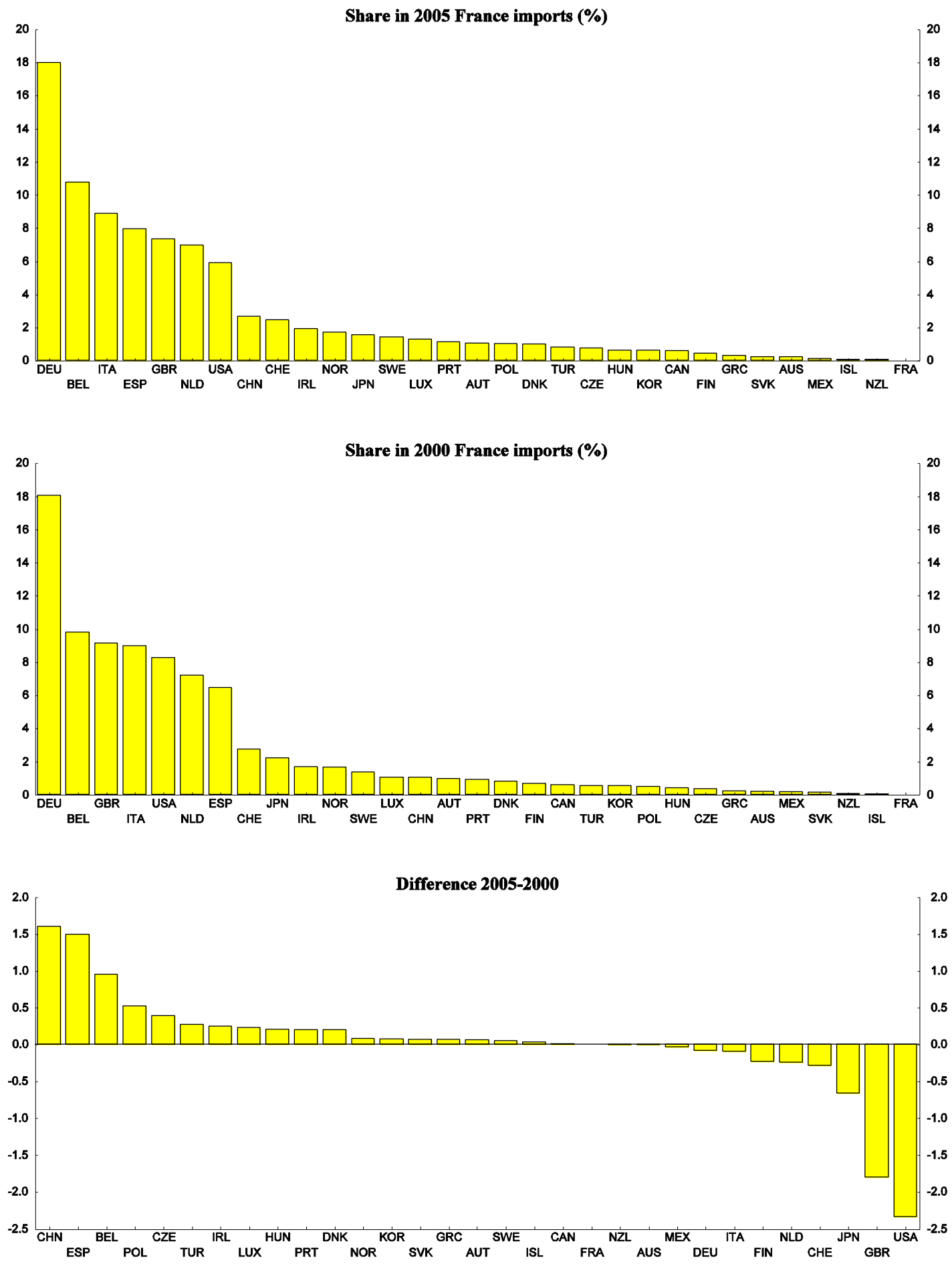
Figure A3.11 Italy export breakdown by destination

Share in 2005 Italy exports (\%)
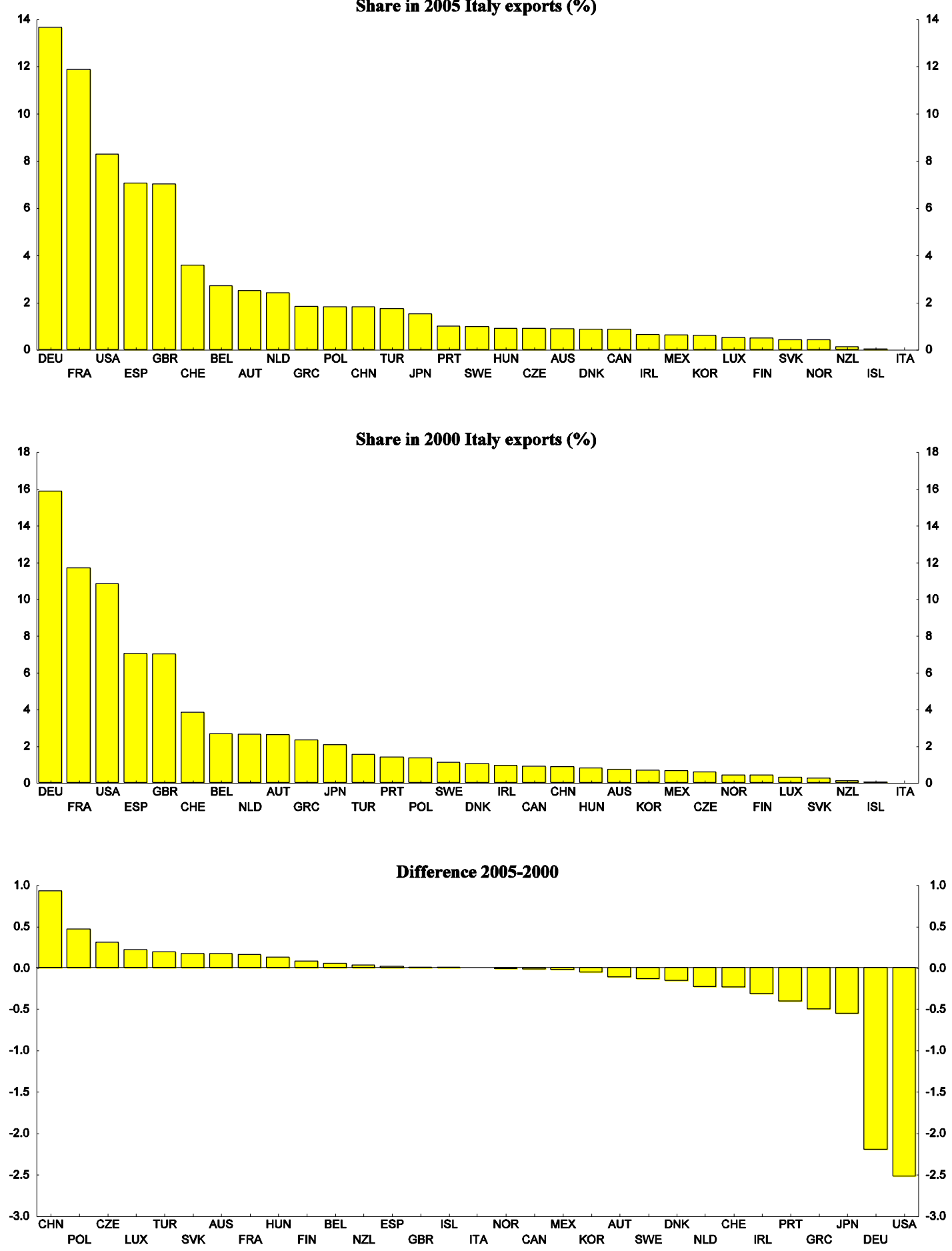
Figure A3.12 Italy import breakdown by origin

Share in 2005 Italy imports (\%)
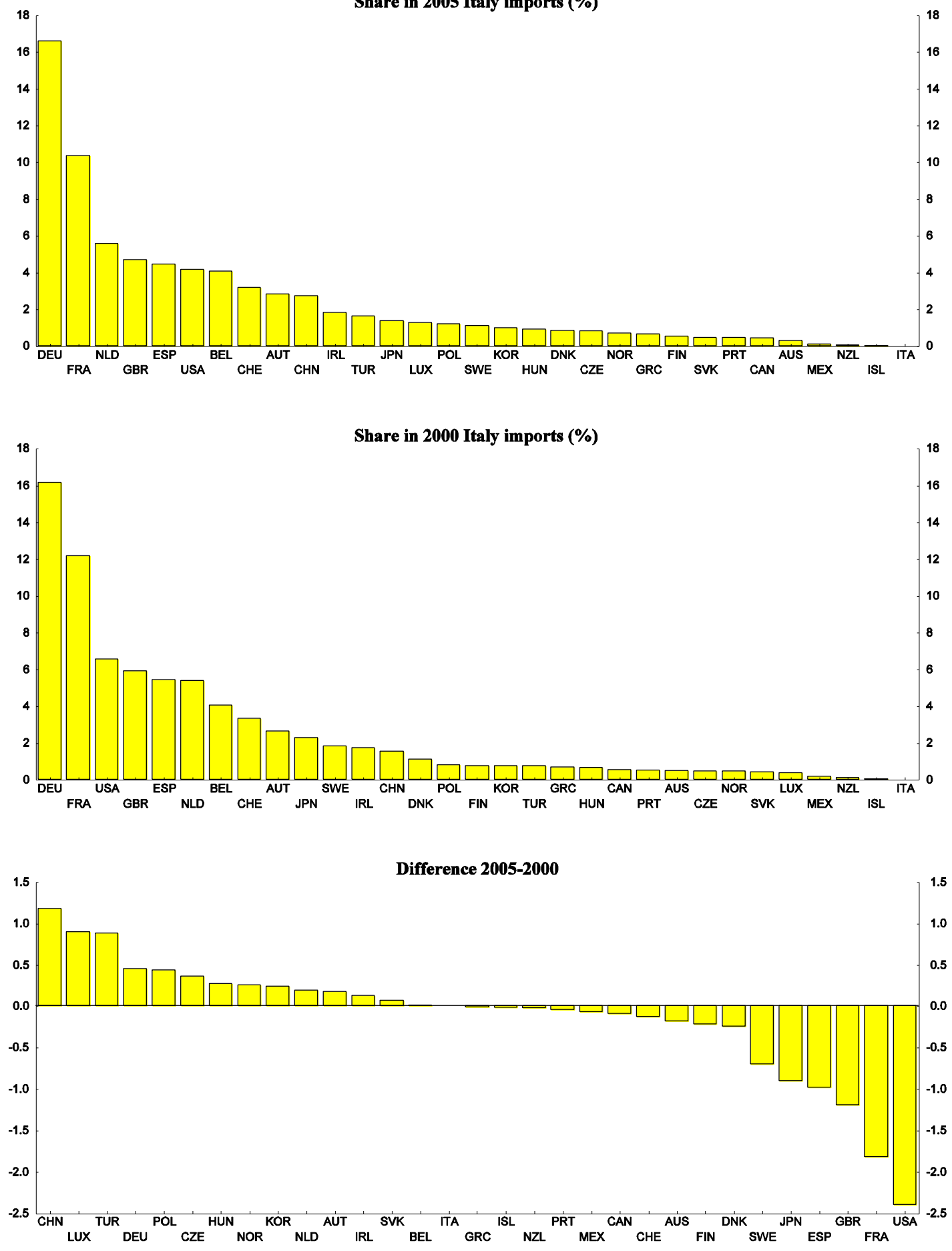
Figure A3.13 United Kingdom export breakdown by destination
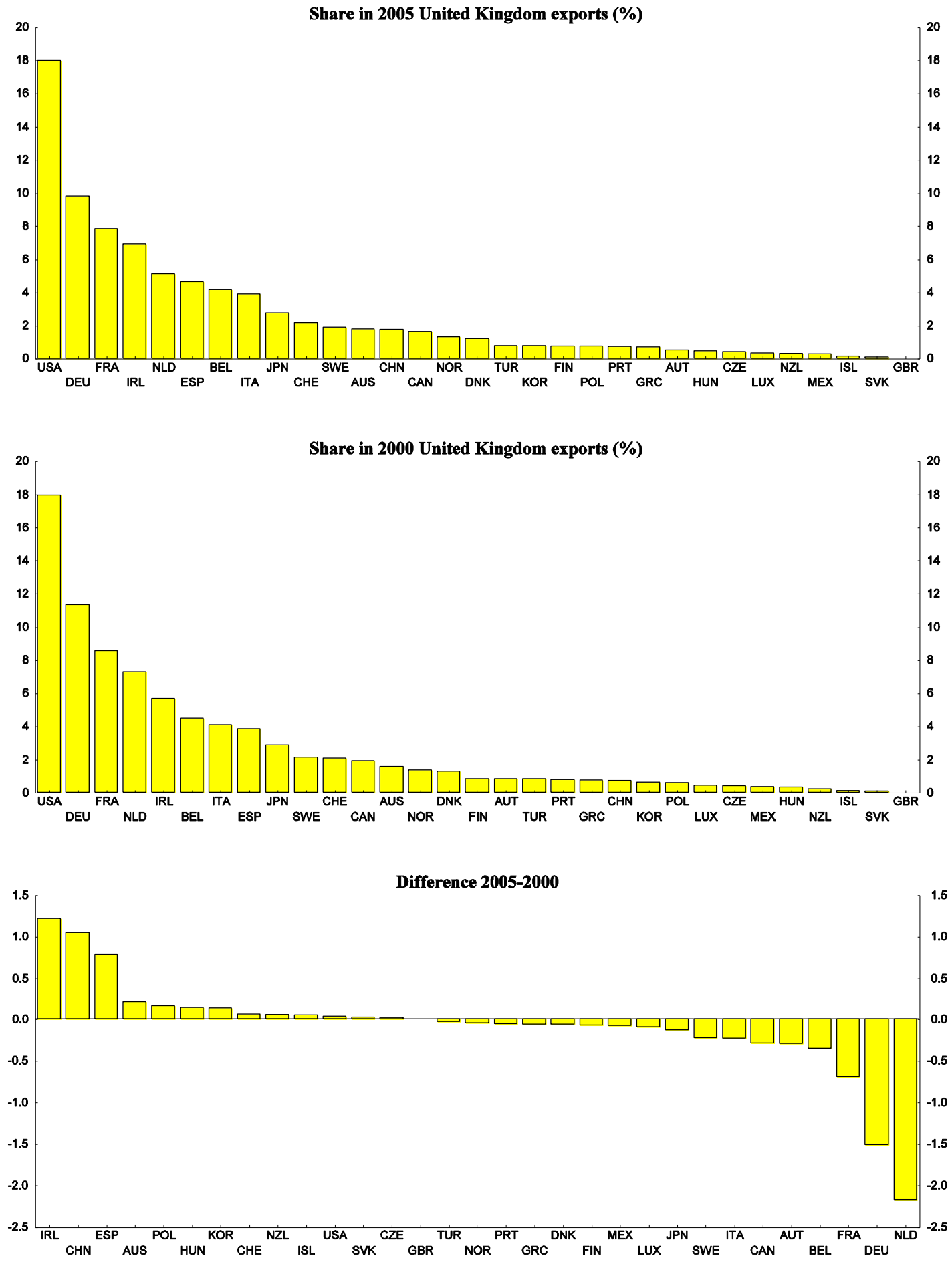
Figure A3.14 United Kingdom import breakdown by origin

Share in 2005 United Kingdom imports (\%)
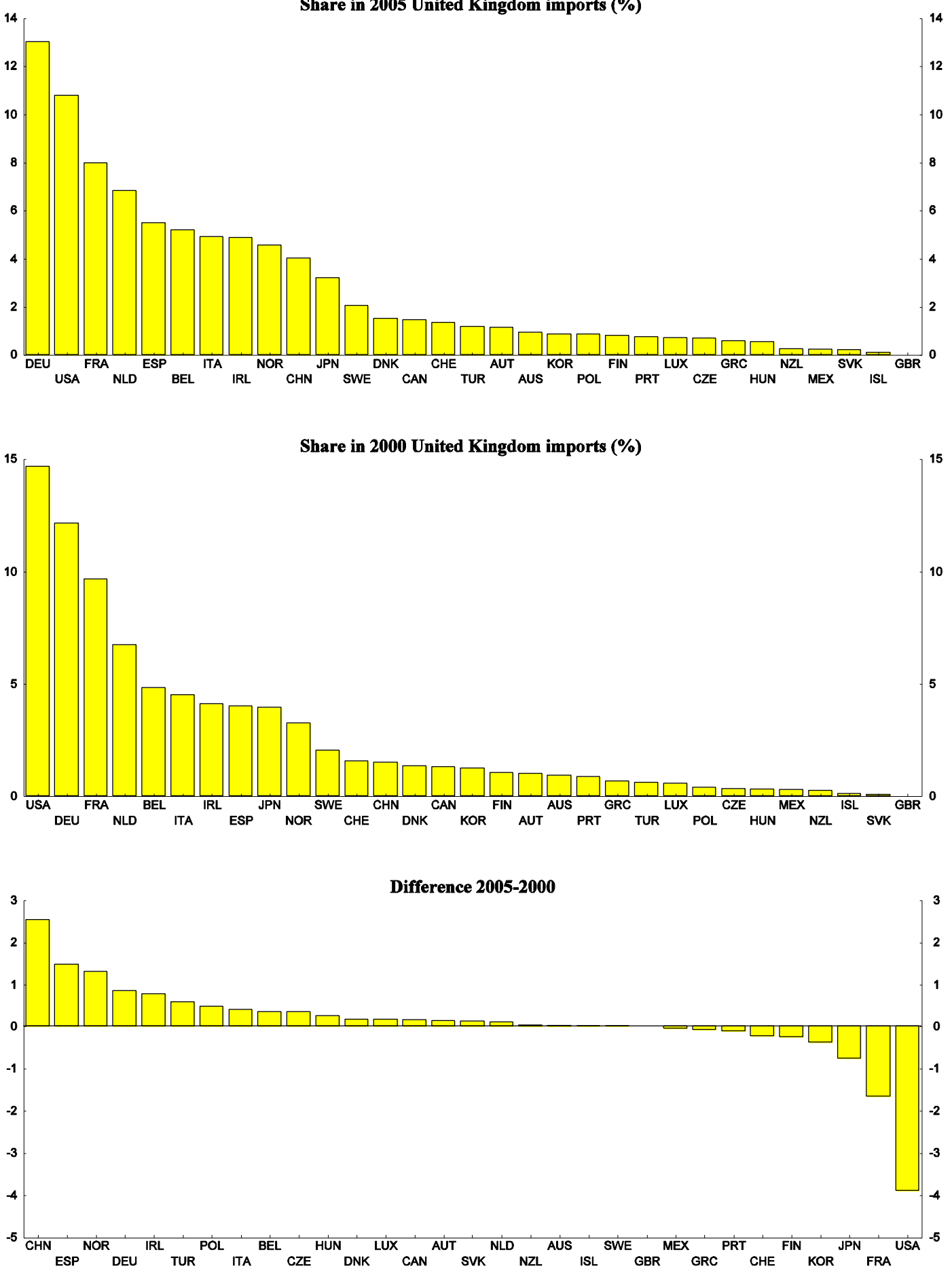
Figure A3.15 Australia export breakdown by destination

Share in 2005 Australia exports (\%)
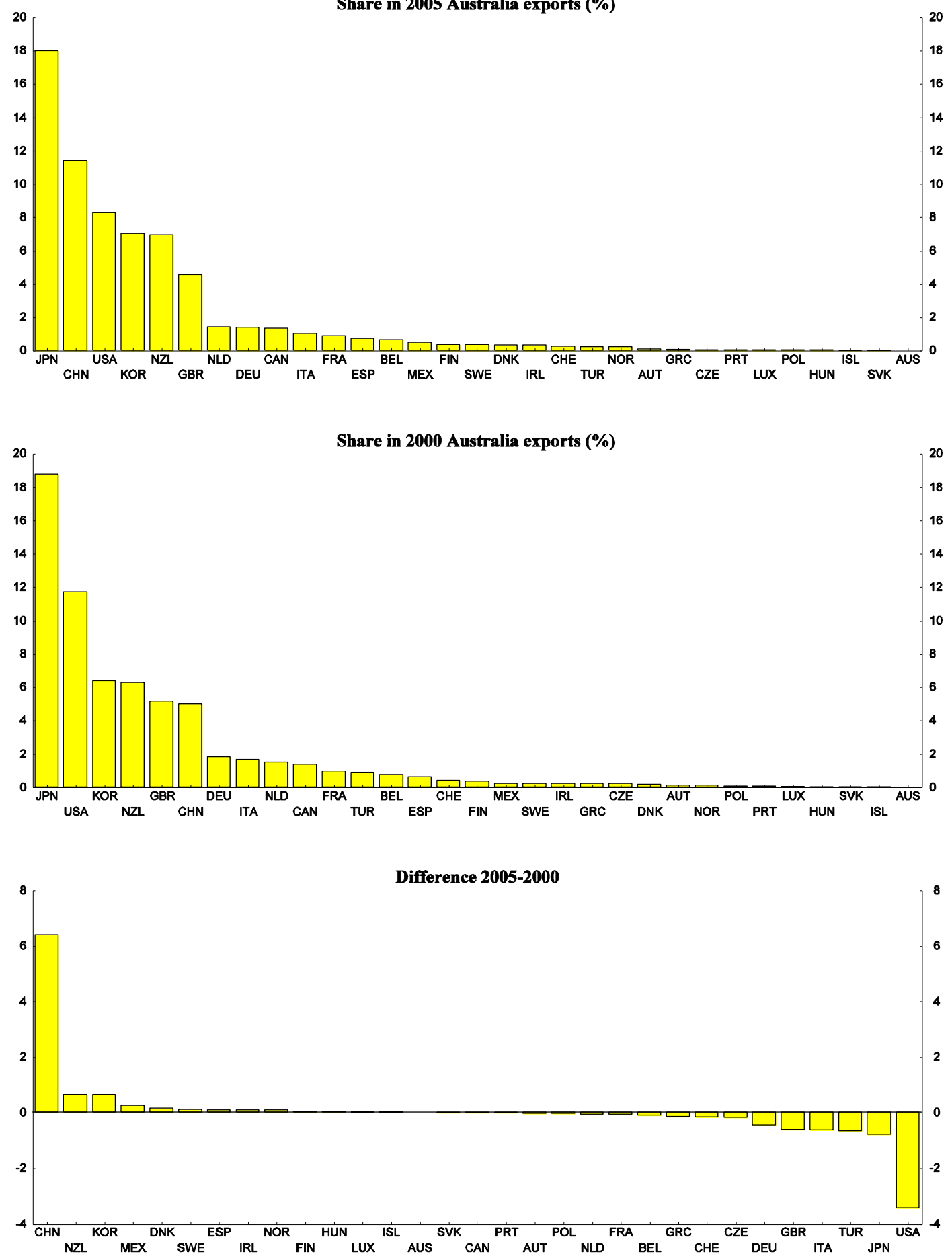
Figure A3.16 Australia import breakdown by origin
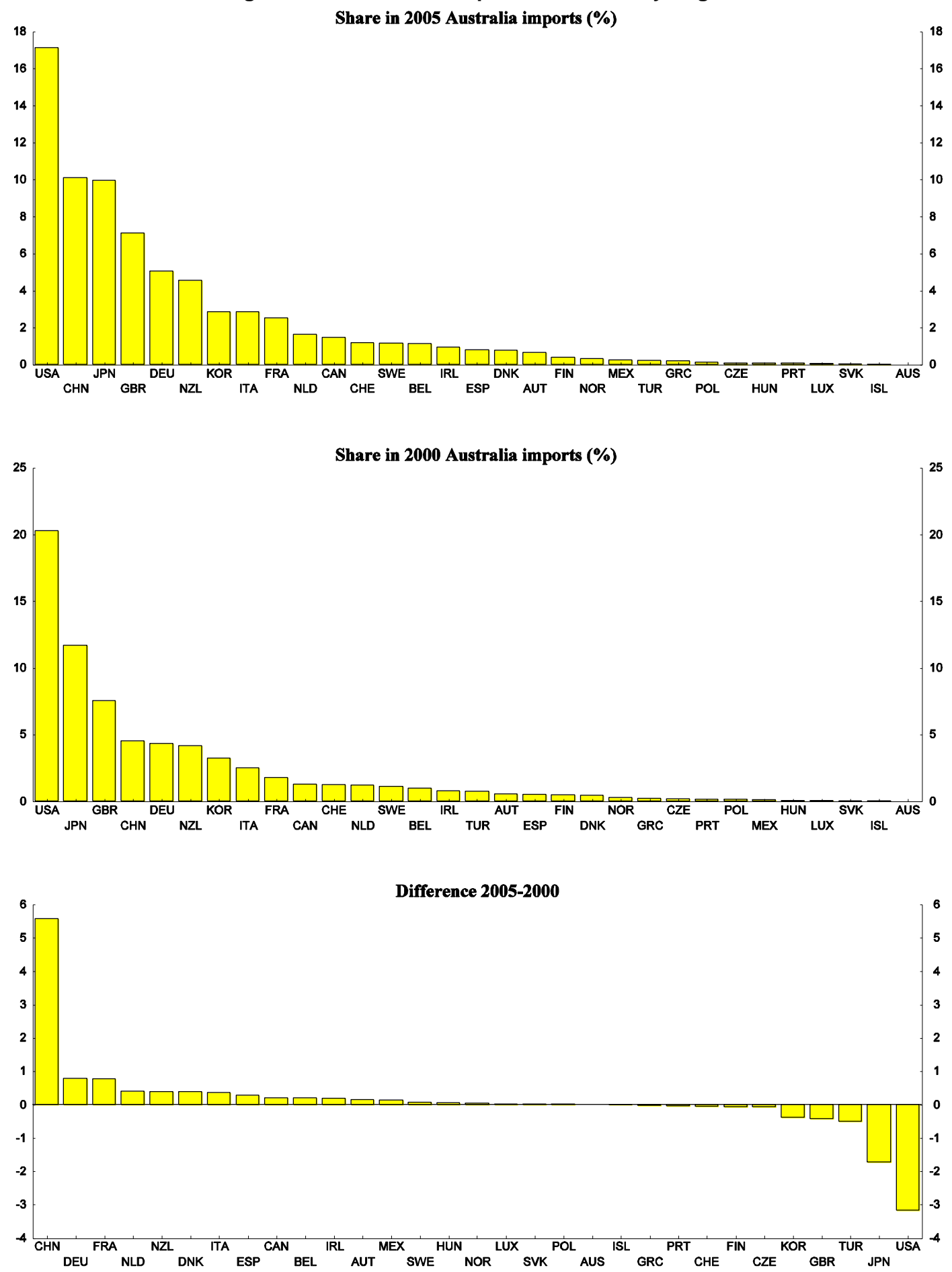
Figure A3.17 Austria export breakdown by destination
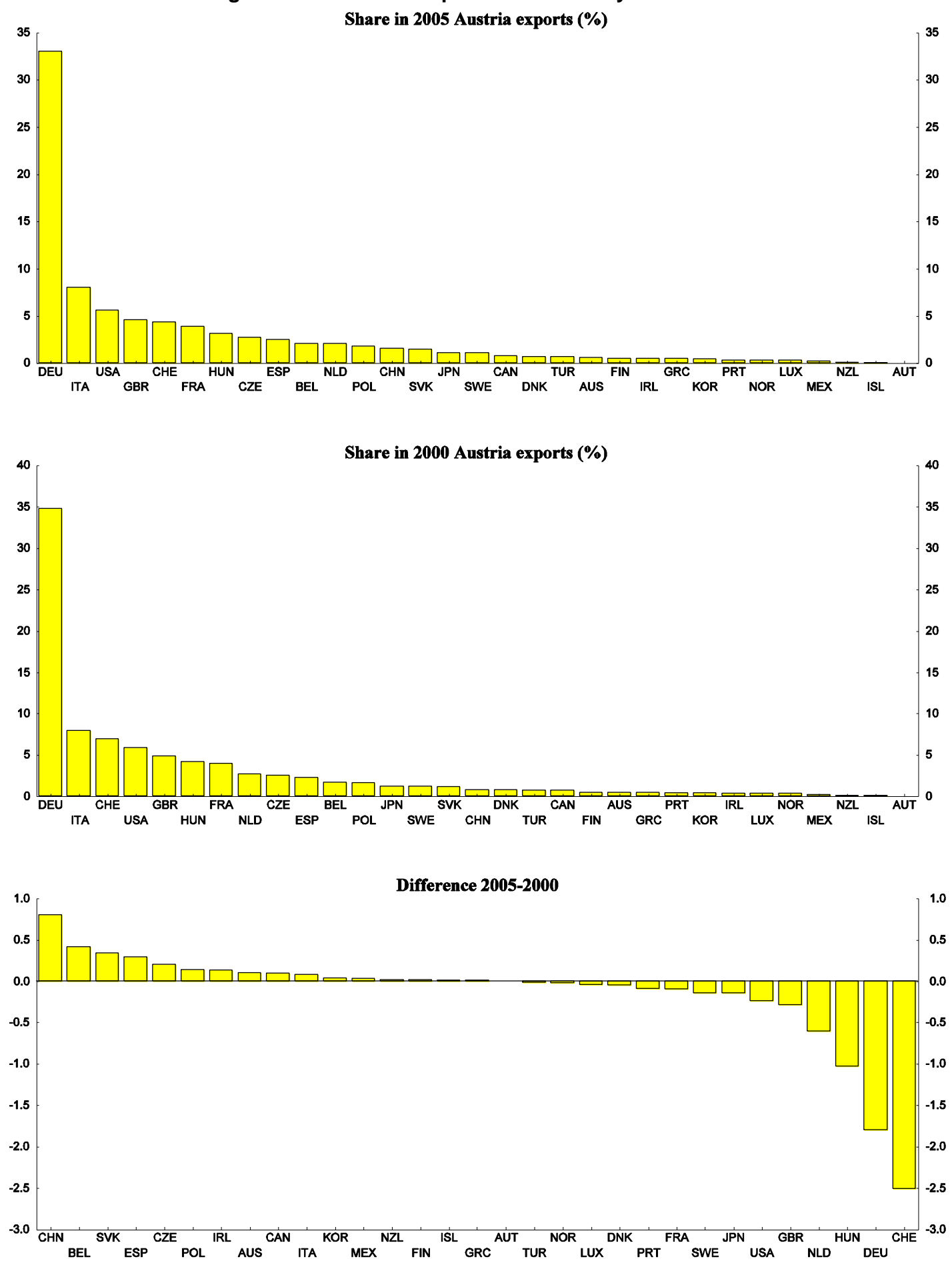
Figure A3.18 Austria import breakdown by origin
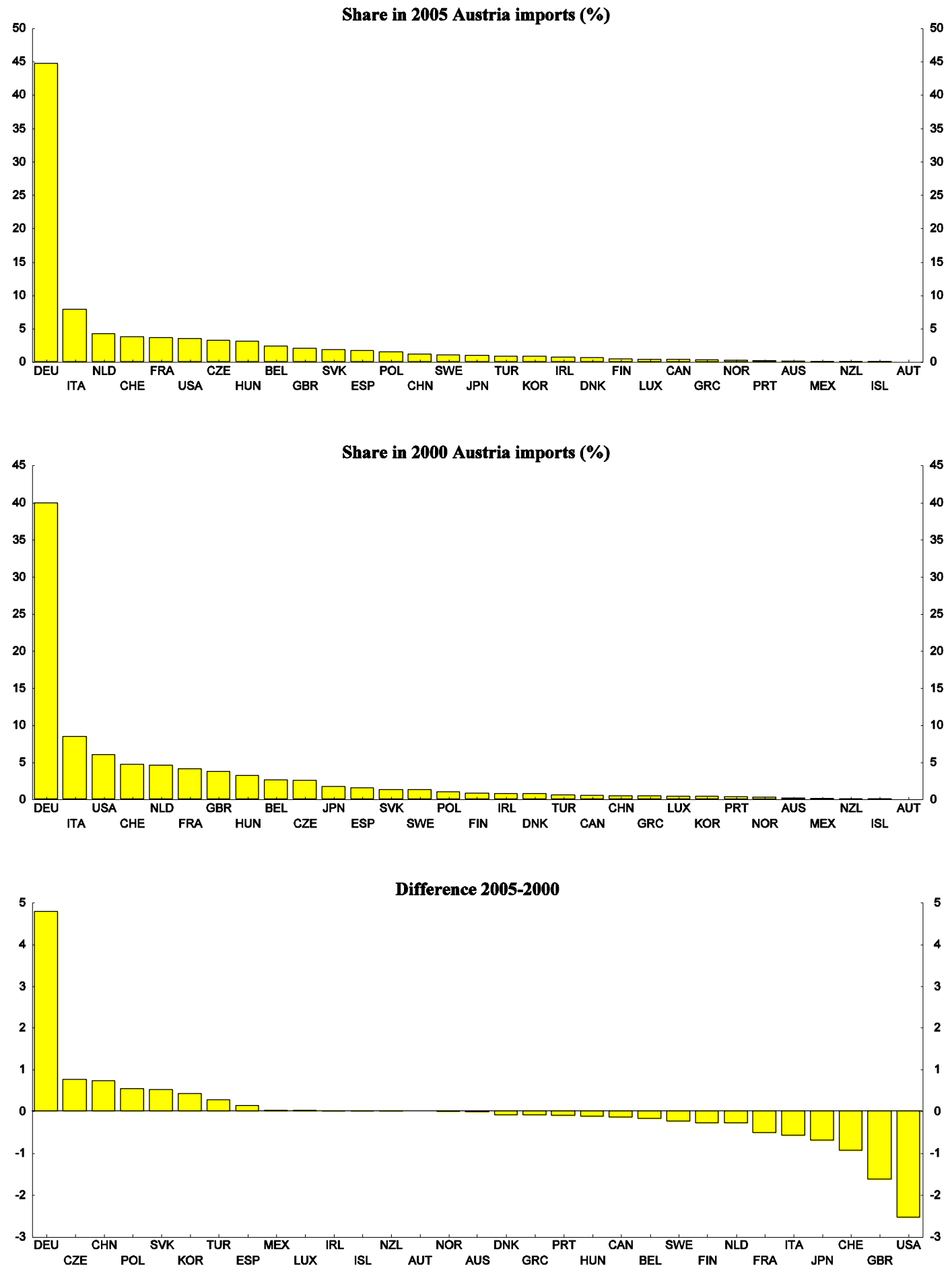
Figure A3.19 Belgium export breakdown by destination
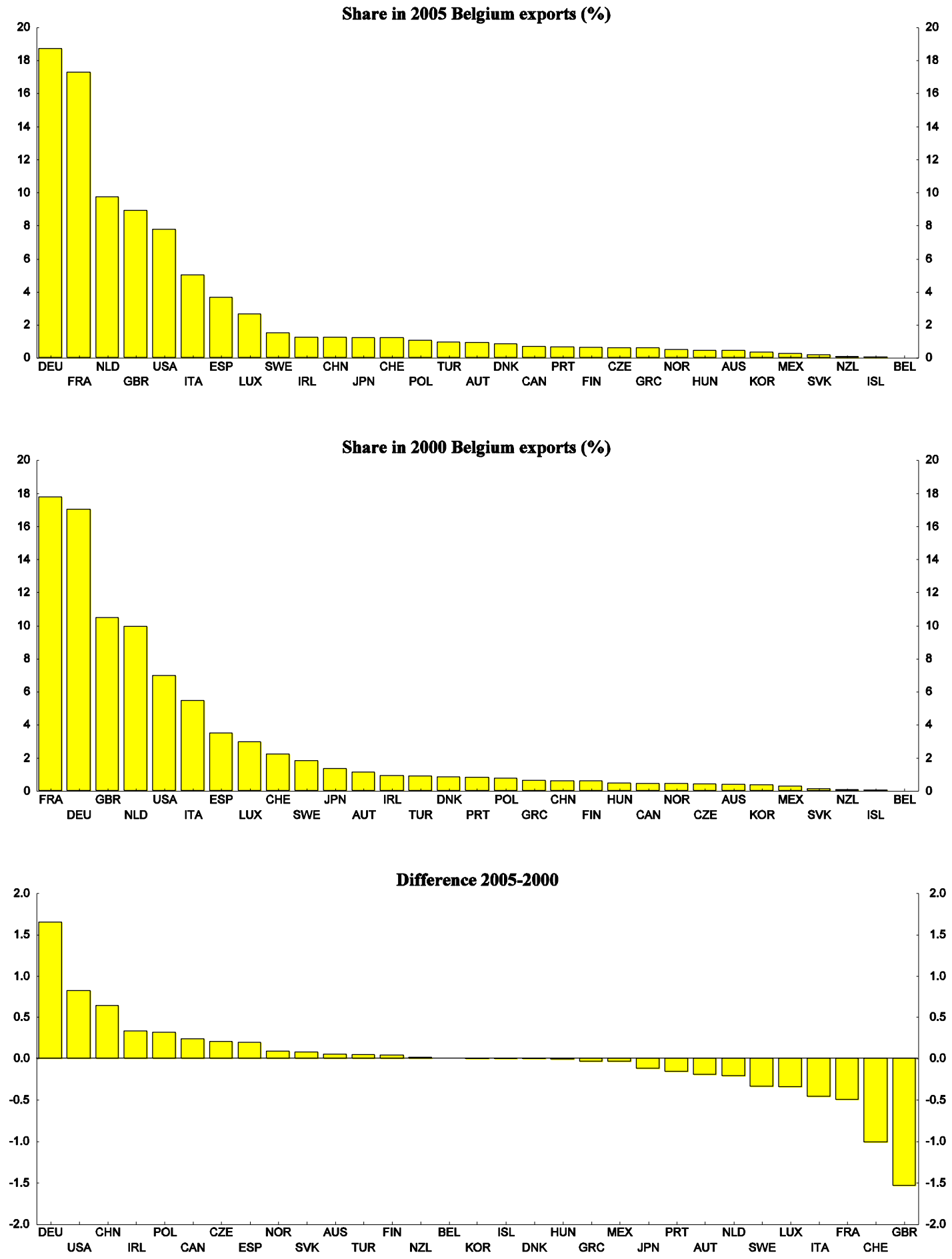
Figure A3.20 Belgium import breakdown by origin
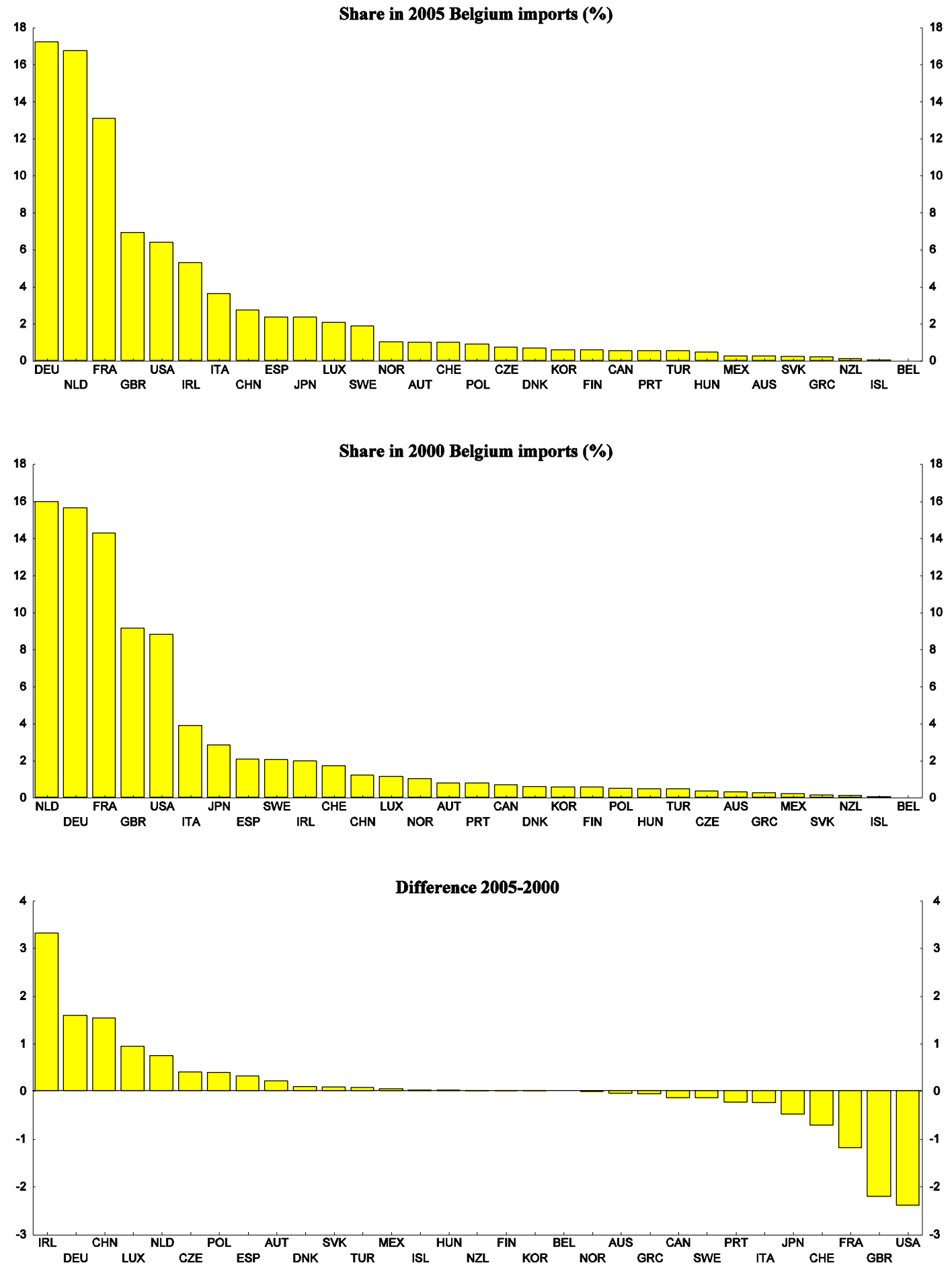
Figure A3.21 Czech Republic export breakdown by destination
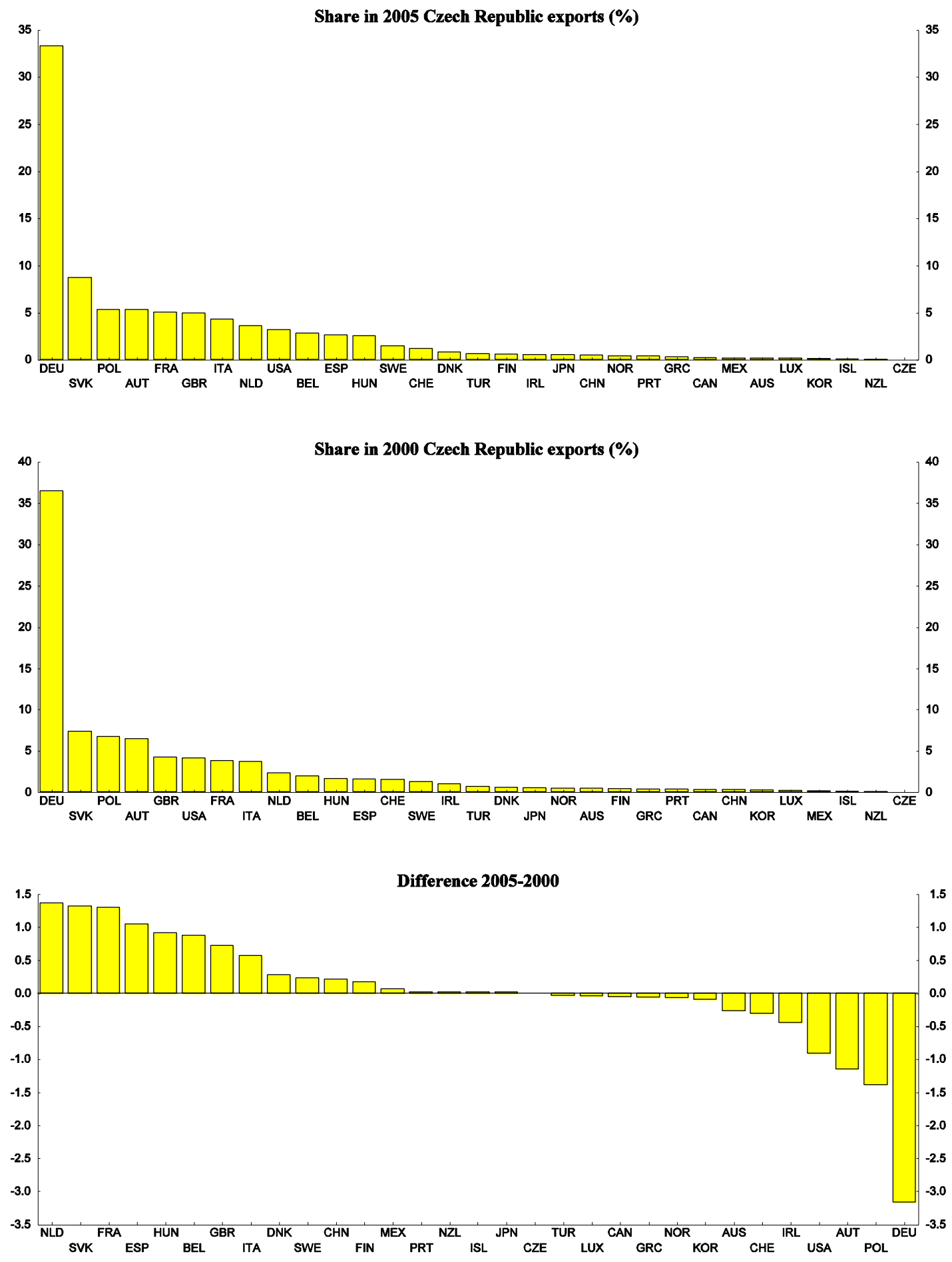
Figure A3.22 Czech Republic import breakdown by origin
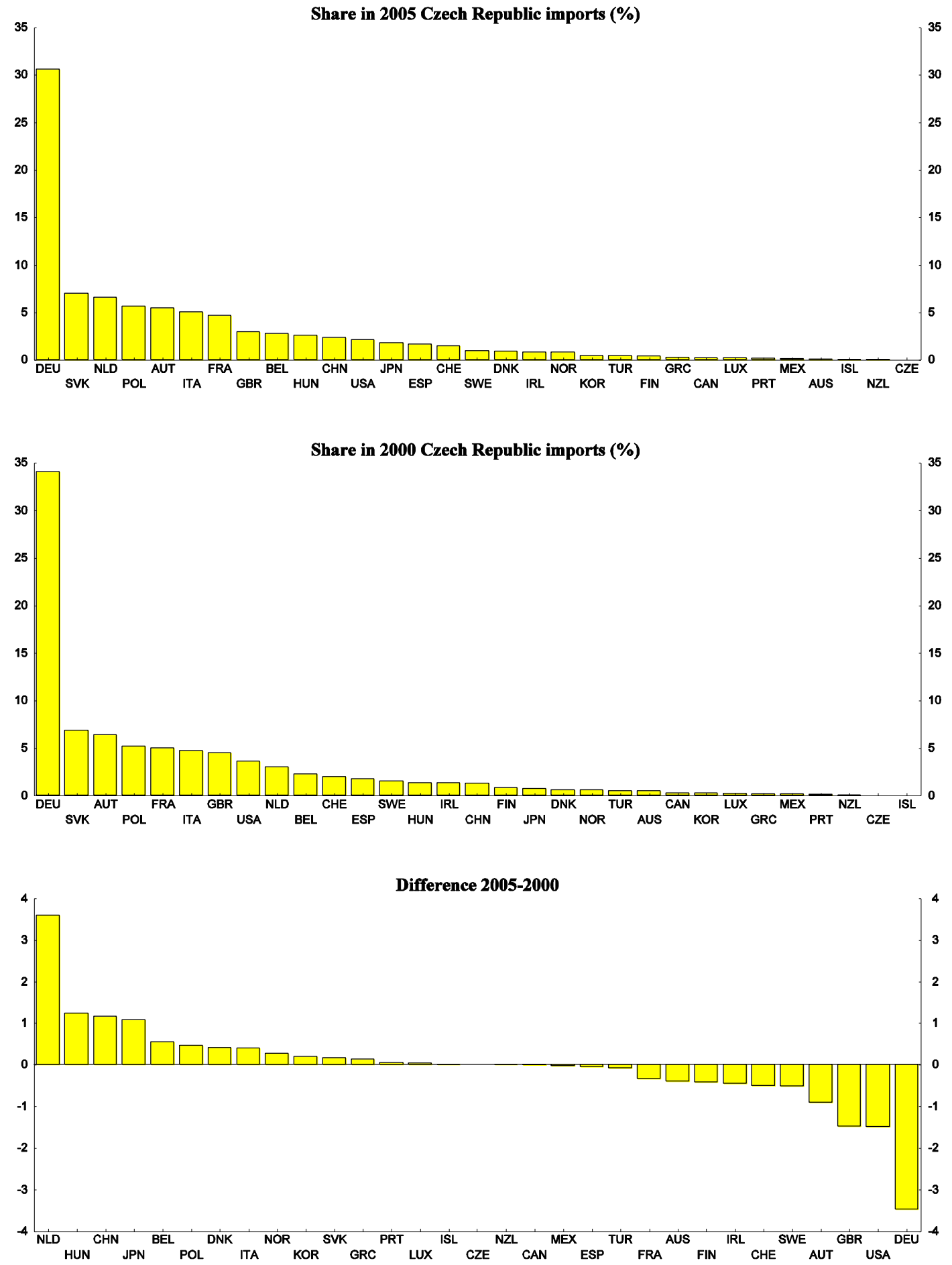
Figure A3.23 Denmark export breakdown by destination

Share in 2005 Denmark exports (\%)
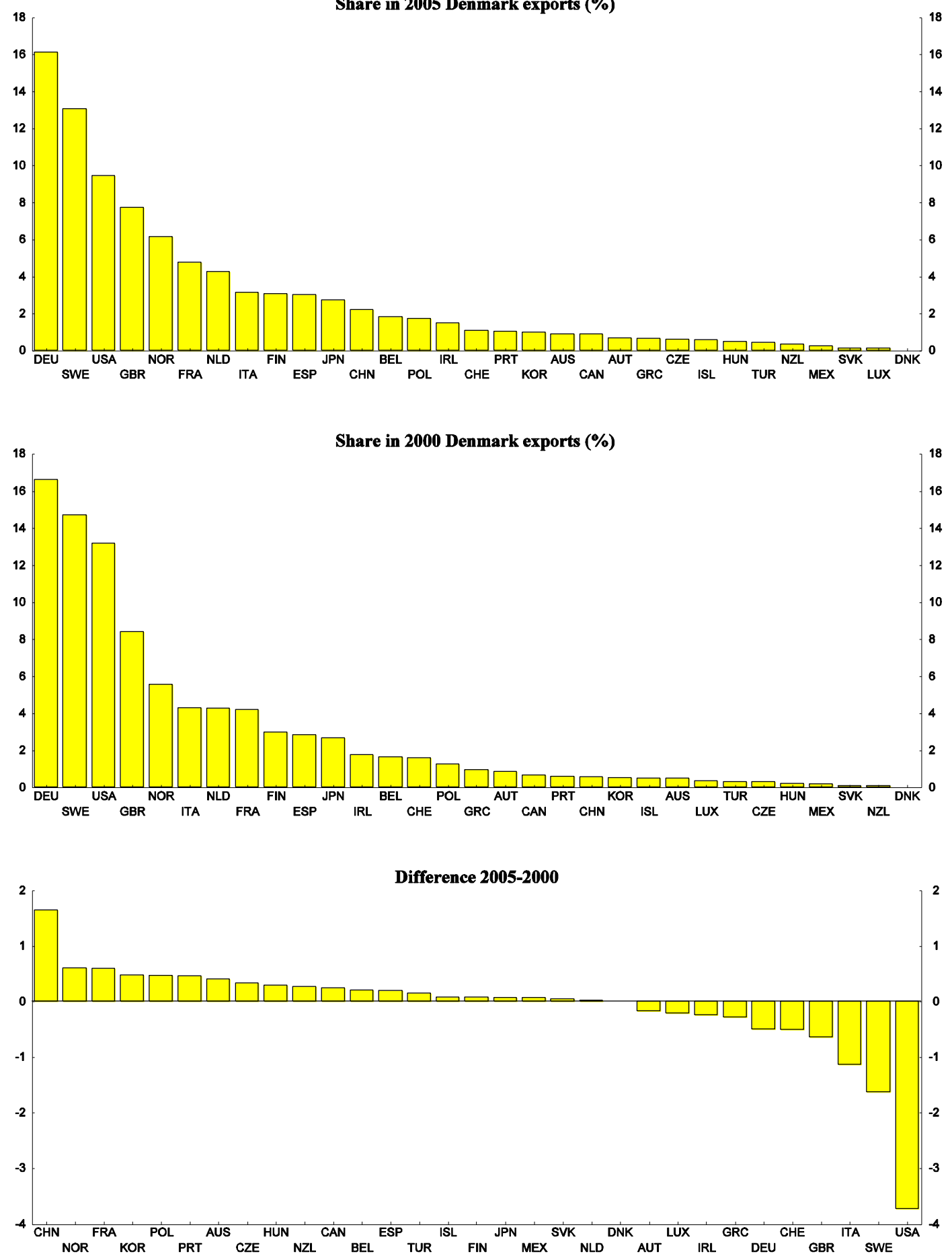
Figure A3.24 Denmark import breakdown by origin
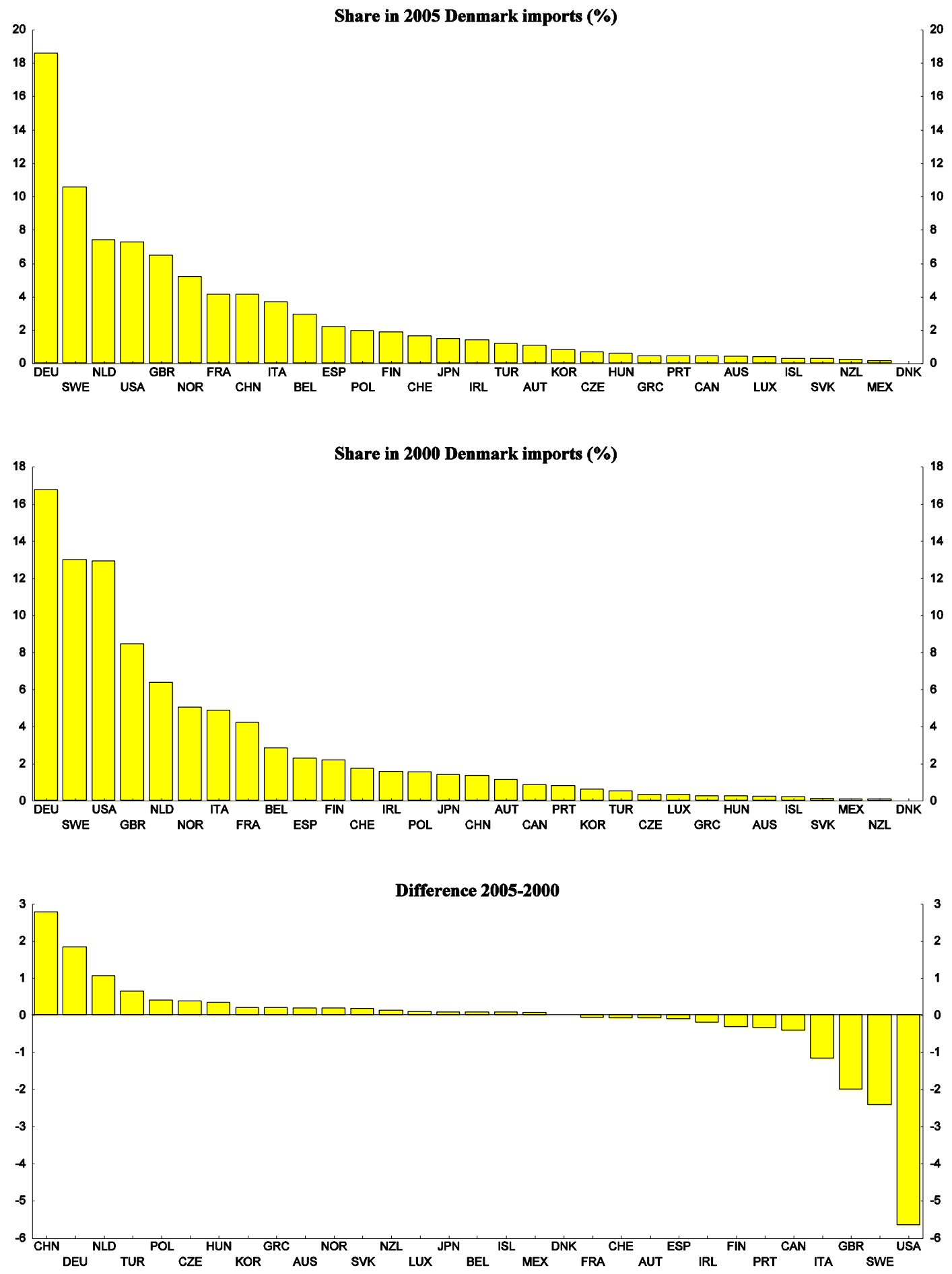
Figure A3.25 Finland export breakdown by destination
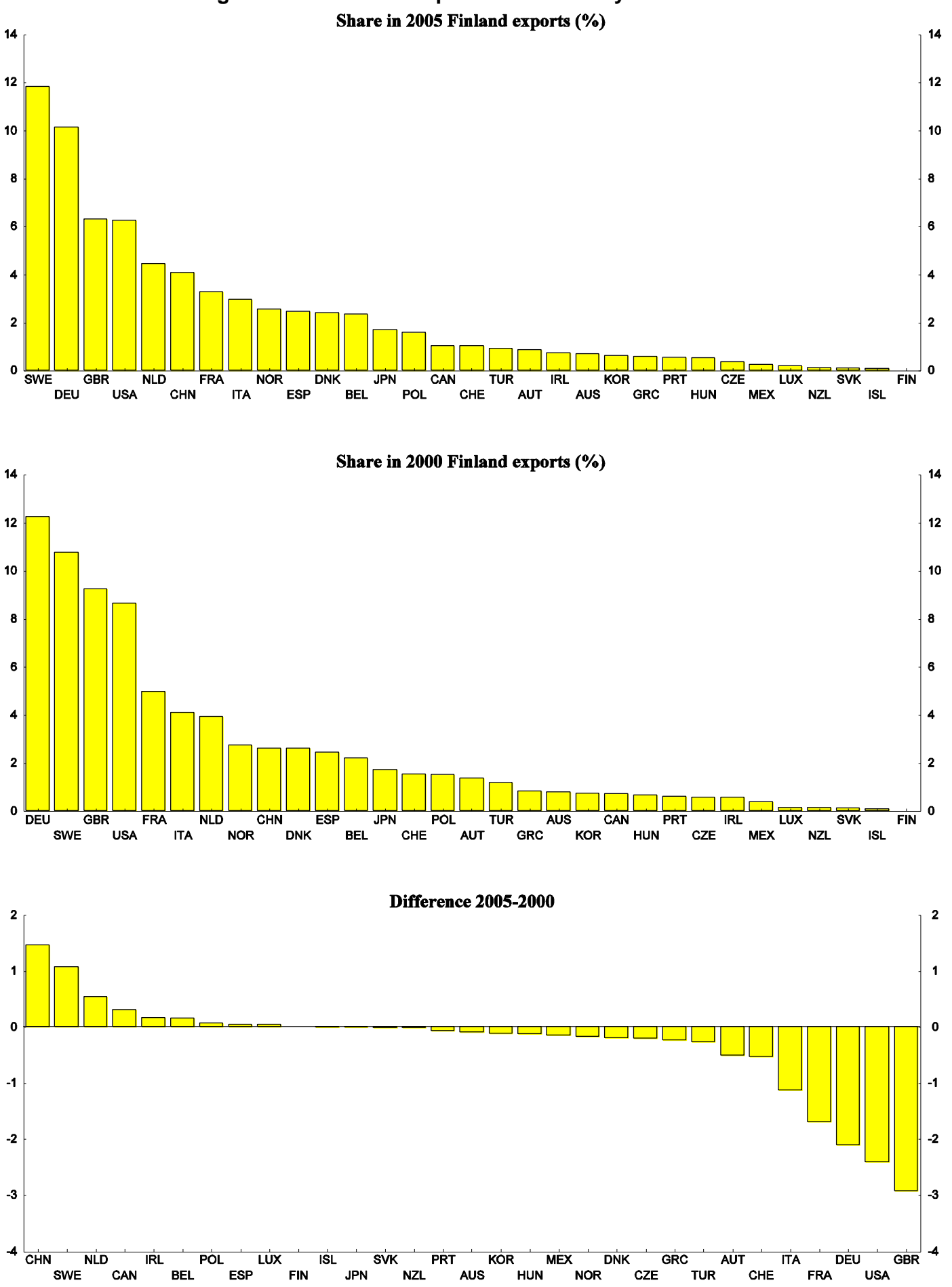
Figure A3.26 Finland import breakdown by origin
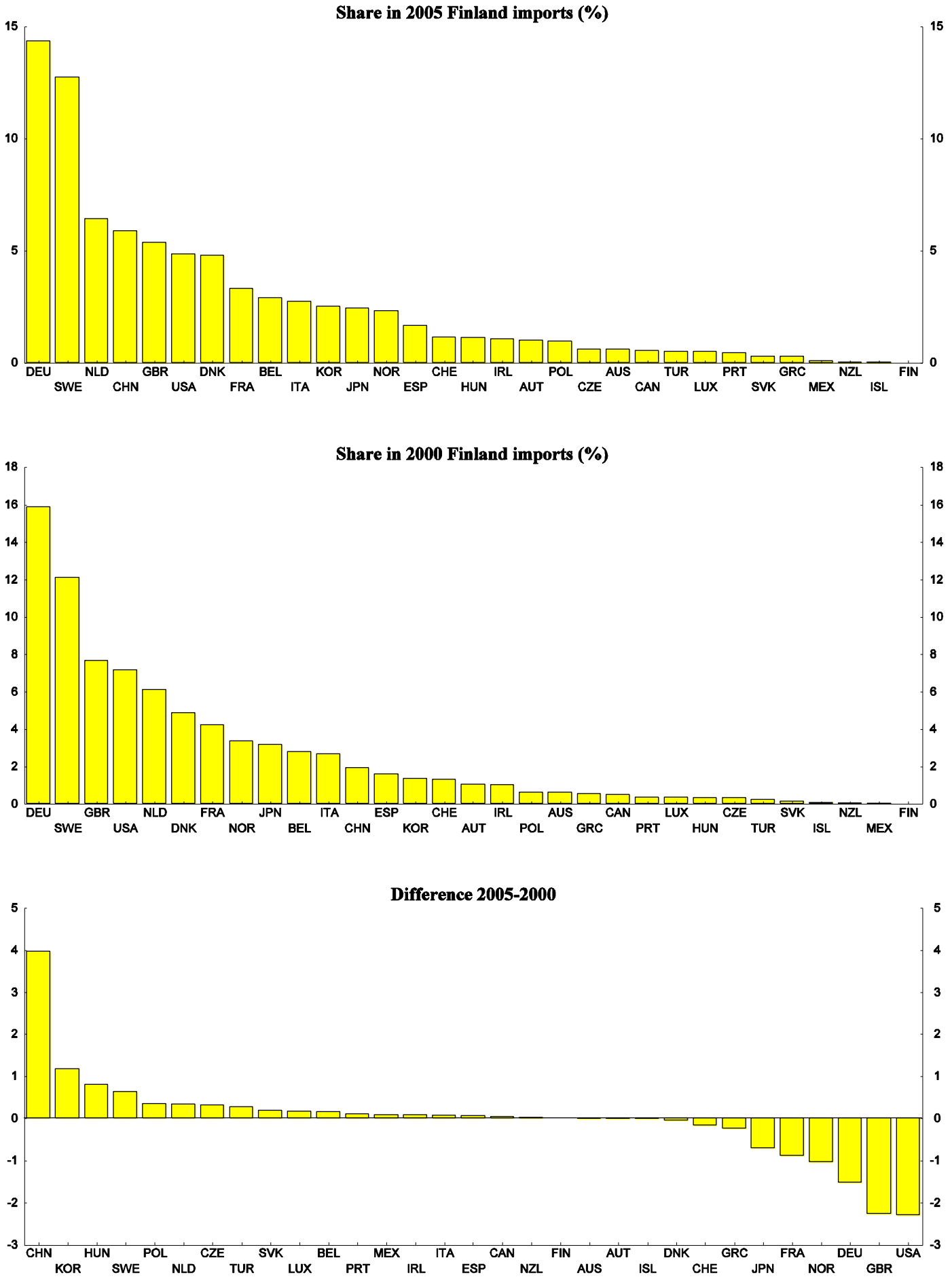
Figure A3.27 Greece export breakdown by destination
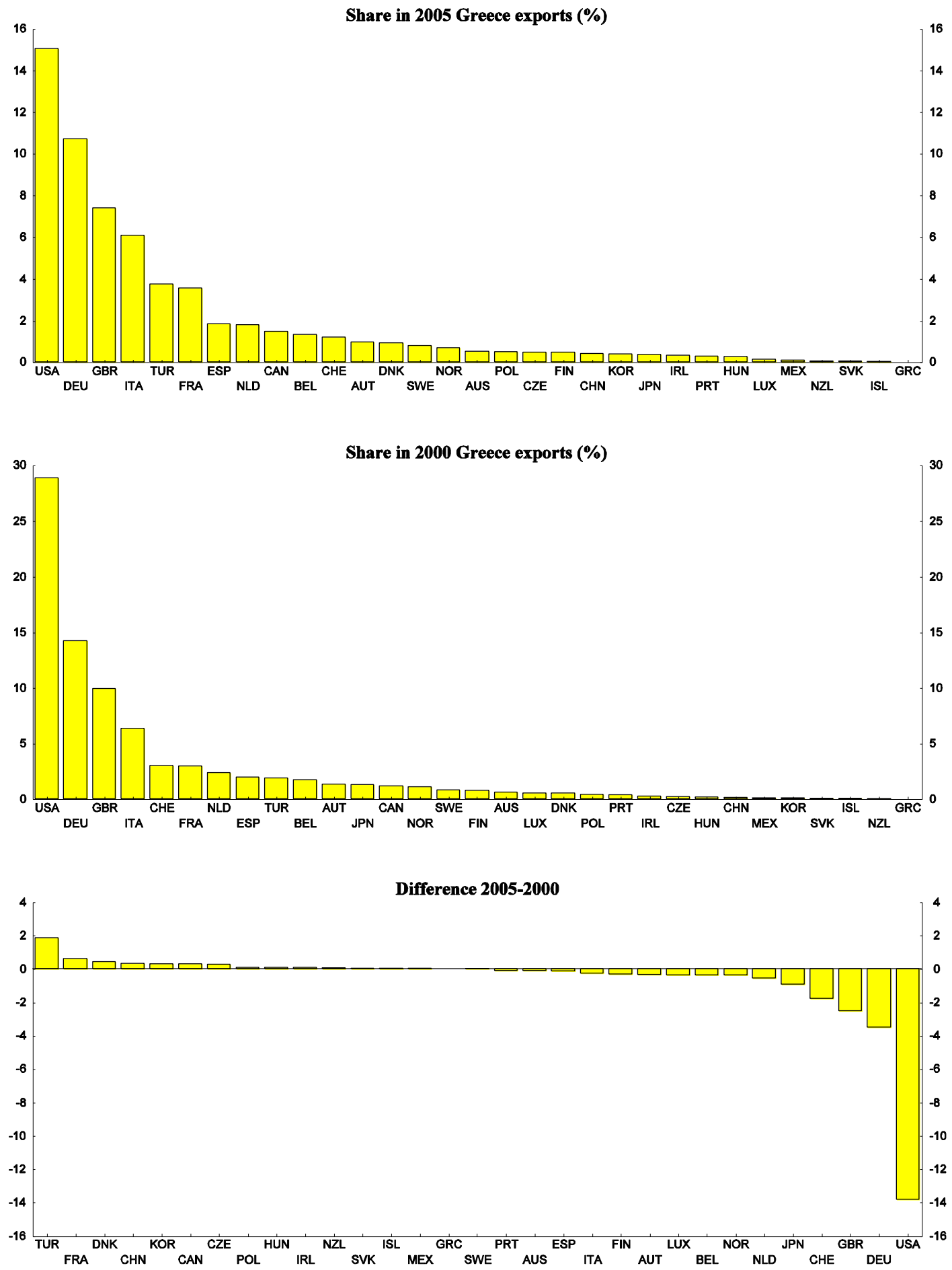
Figure A3.28 Greece import breakdown by origin
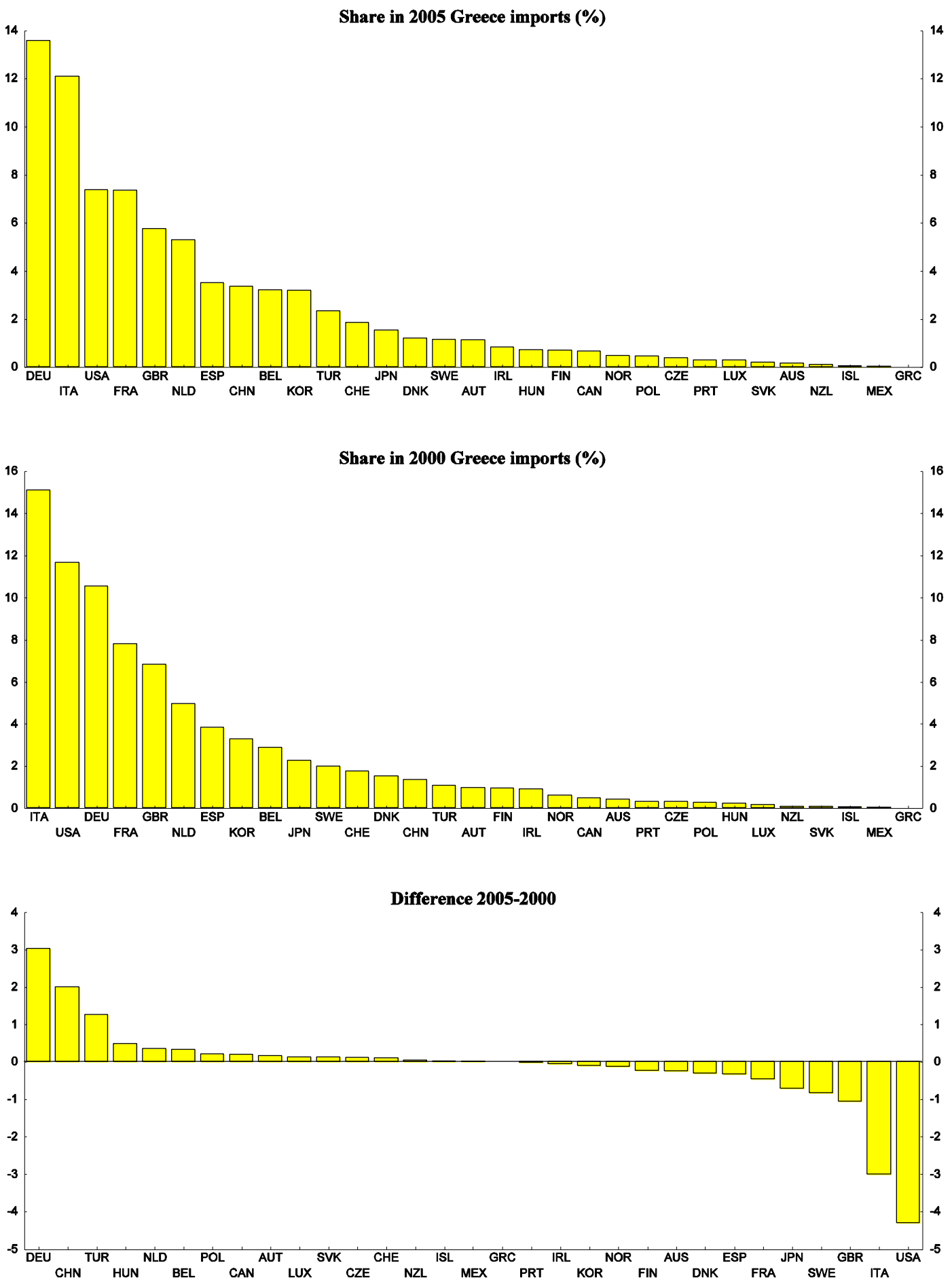
Figure A3.29 Hungary export breakdown by destination
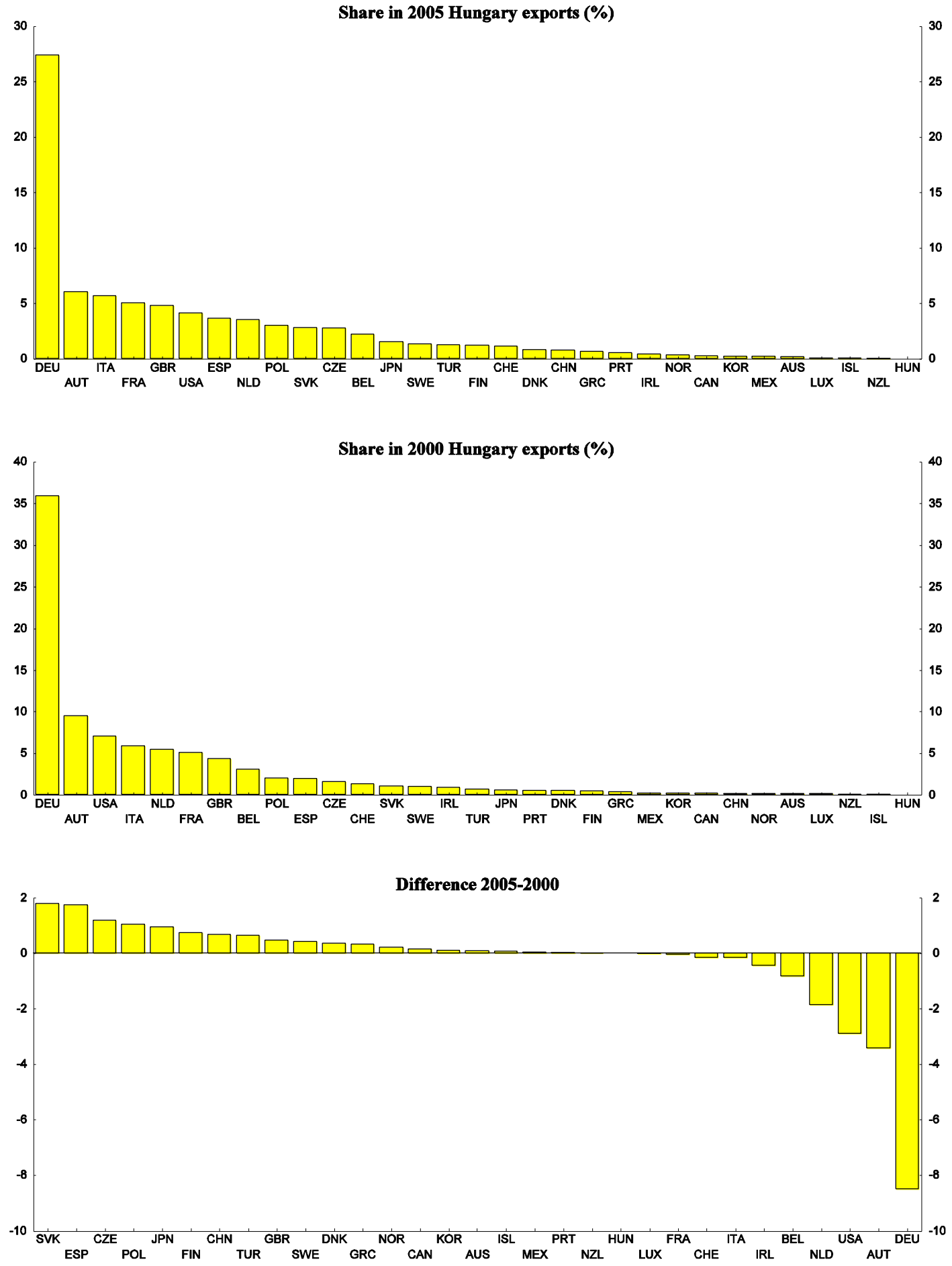
Figure A3.30 Hungary import breakdown by origin
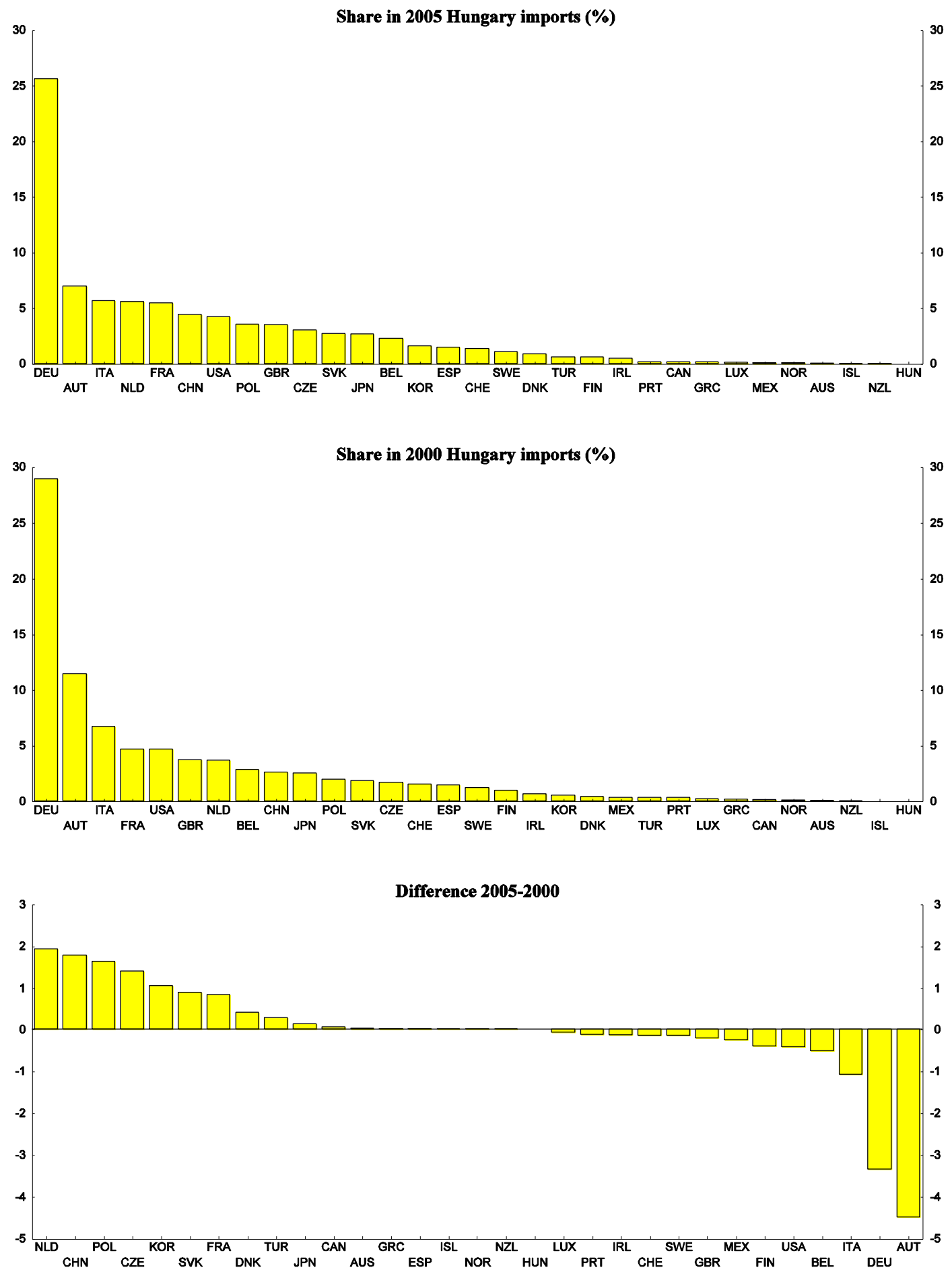
Figure A3.31 Iceland export breakdown by destination
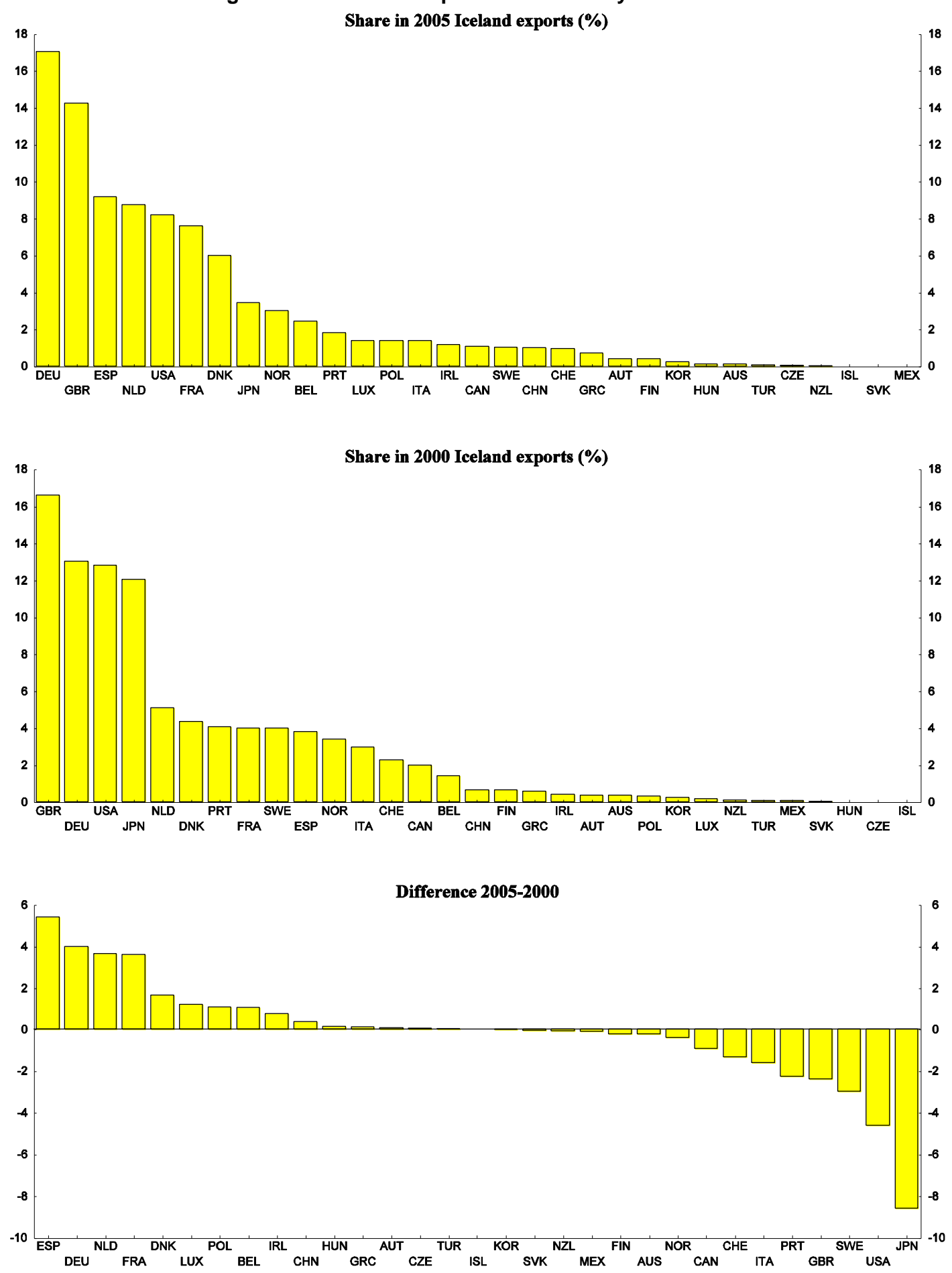
Figure A3.32 Iceland import breakdown by origin
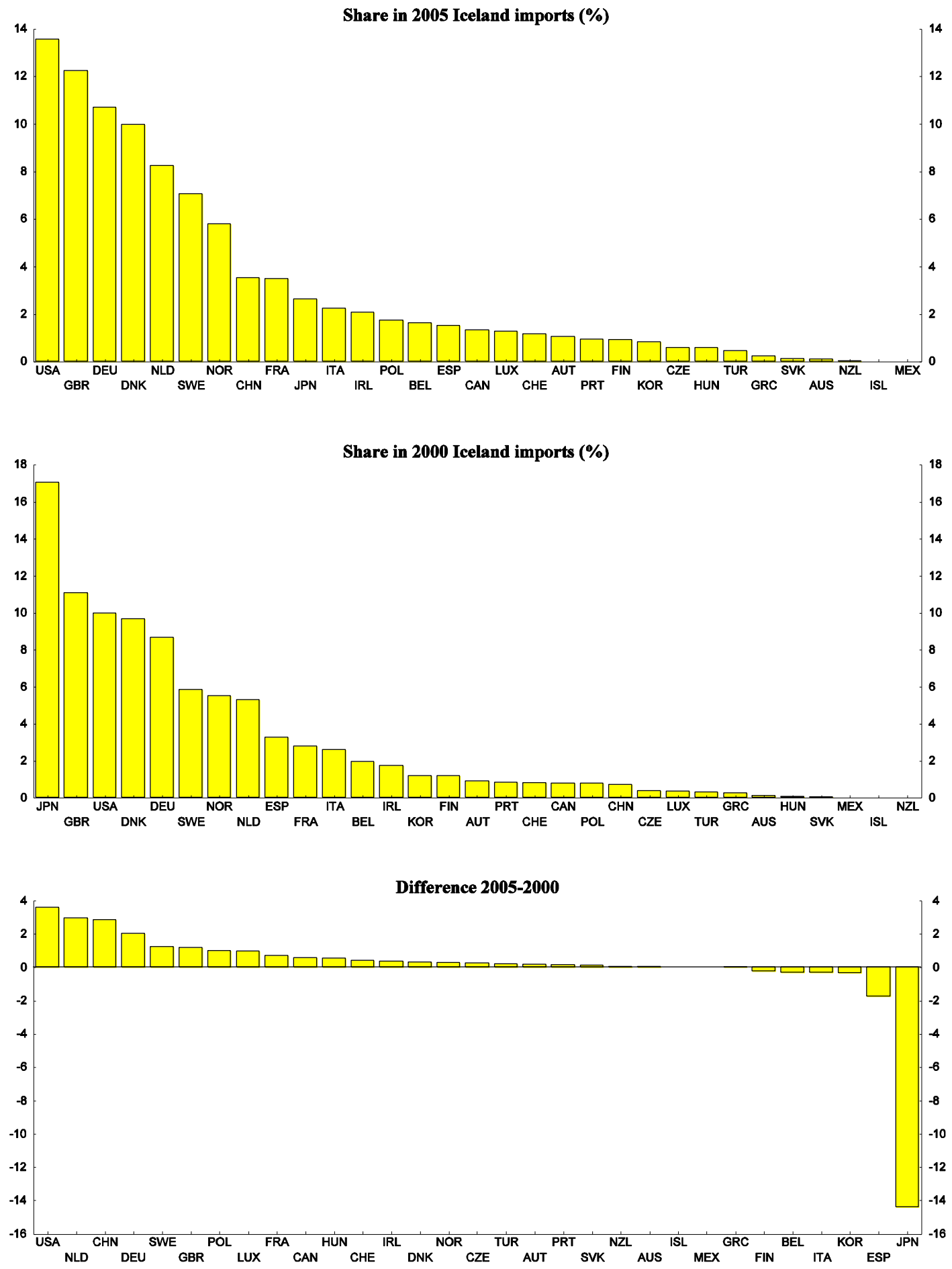
Figure A3.33 Ireland export breakdown by destination
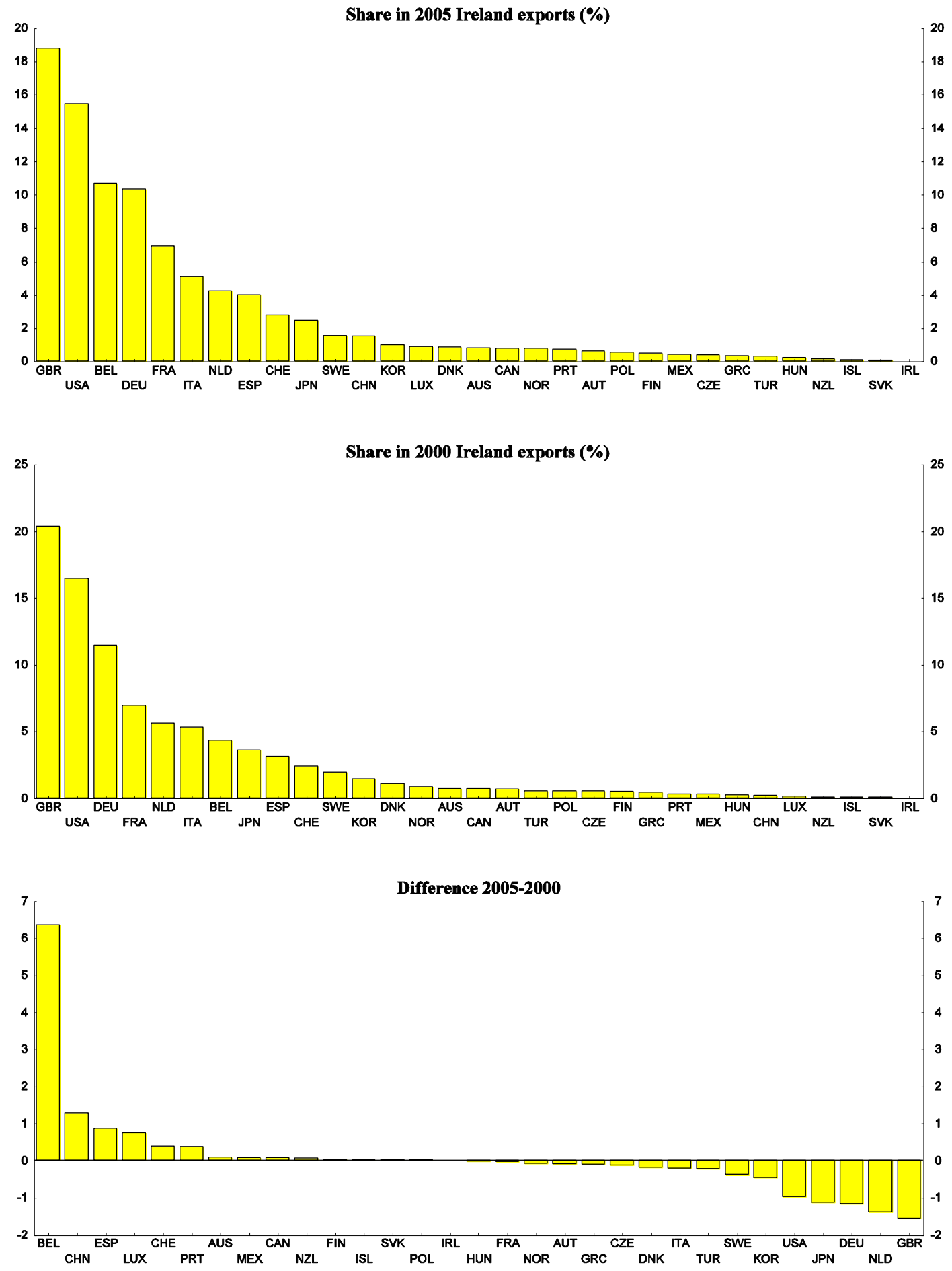
Figure A3.34 Ireland import breakdown by origin
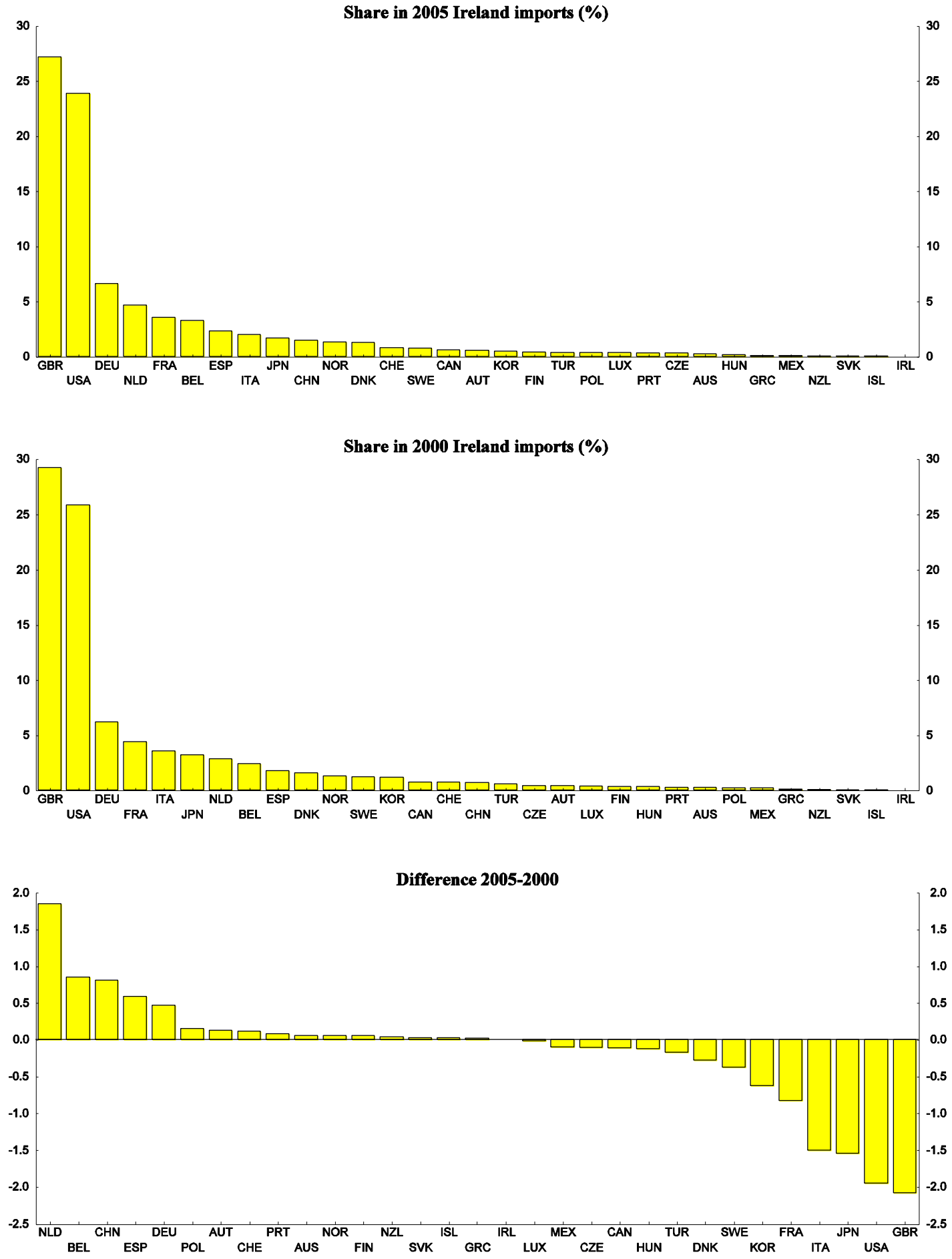
Figure A3.35 Korea export breakdown by destination

Share in 2005 Korea exports (\%)
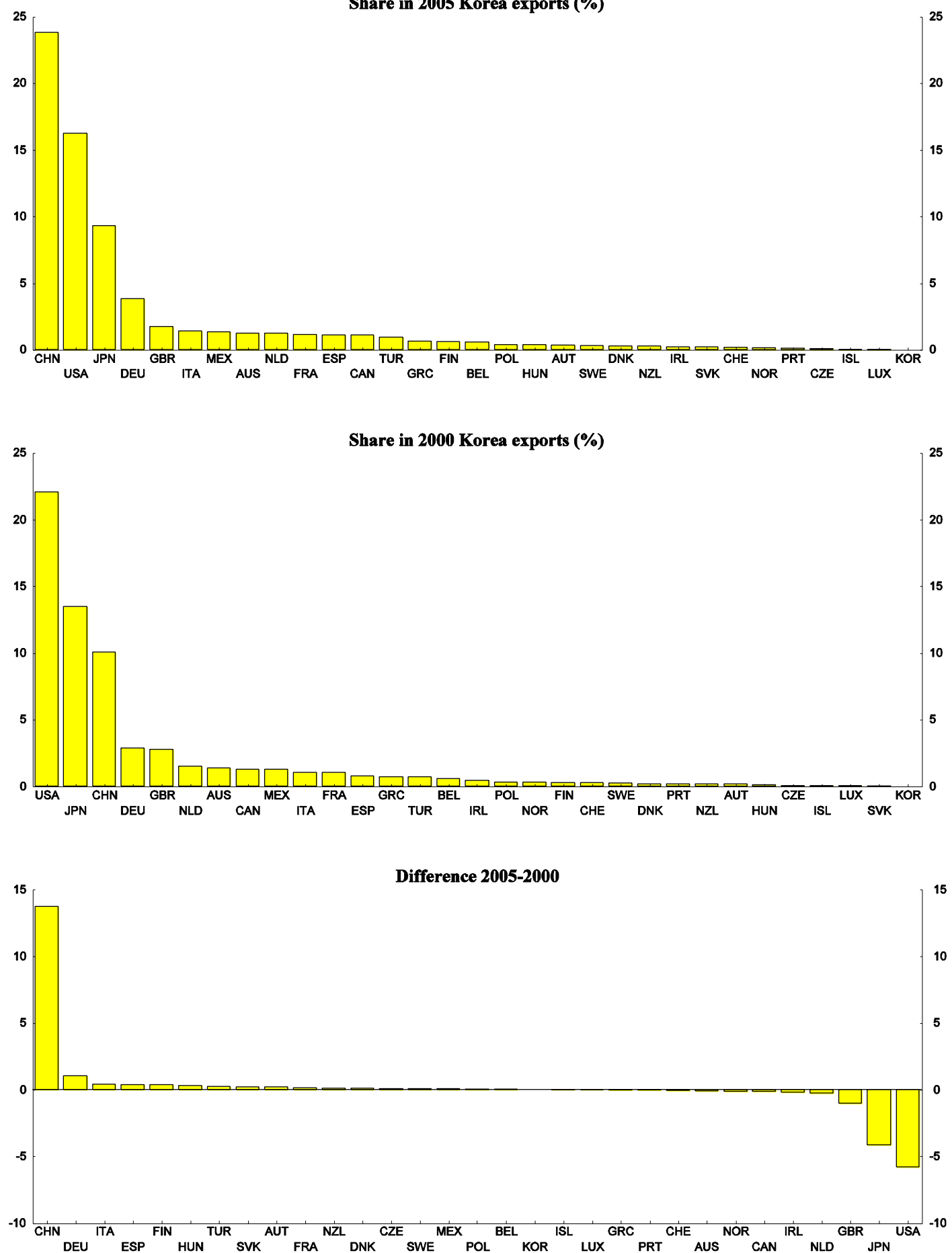
Figure A3.36 Korea import breakdown by origin
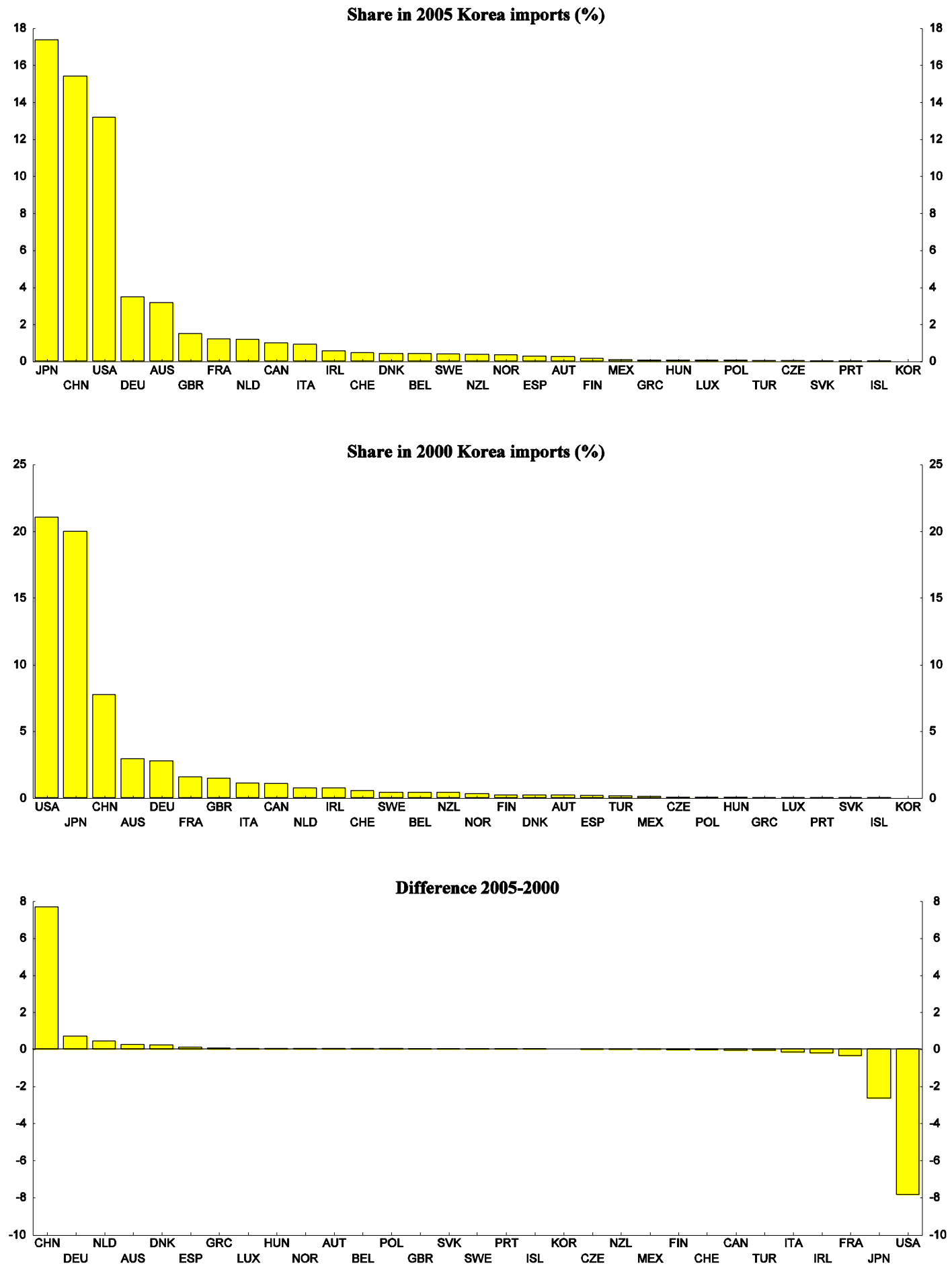
Figure A3.37 Luxembourg export breakdown by destination

Share in 2005 Luxembourg exports (\%)
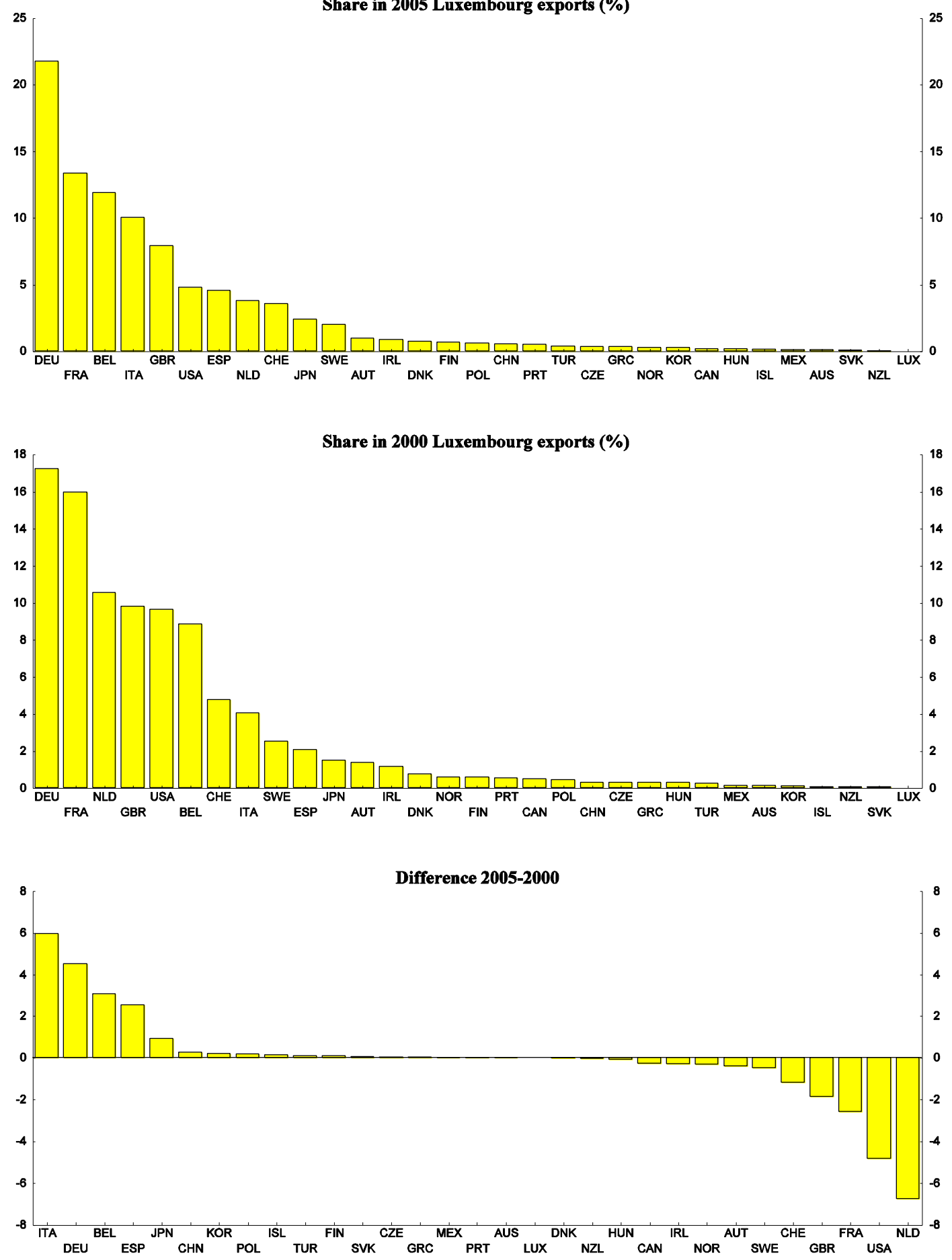
Figure A3.38 Luxembourg import breakdown by origin

Share in 2005 Luxembourg imports (\%)
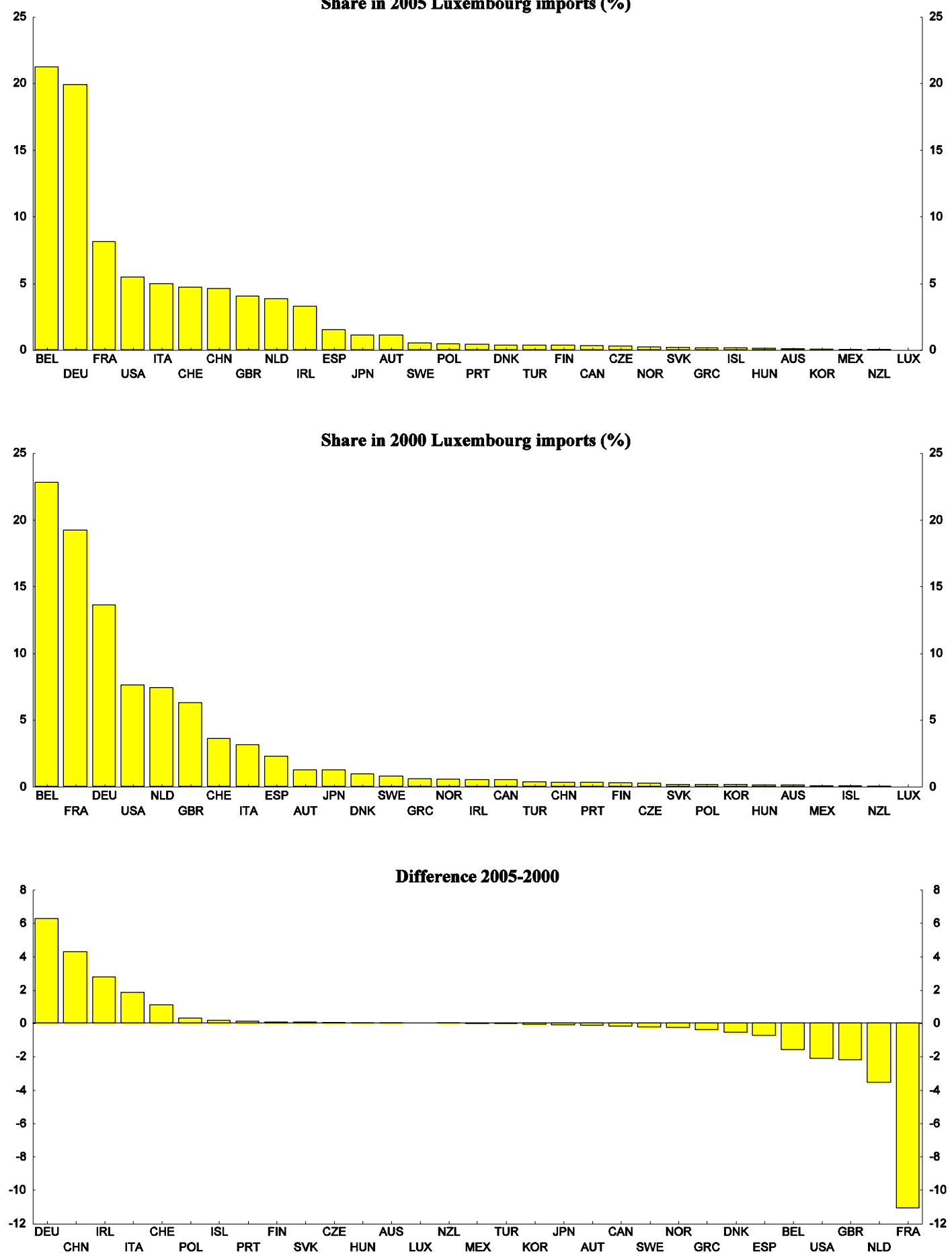
Figure A3.39 Mexico export breakdown by destination
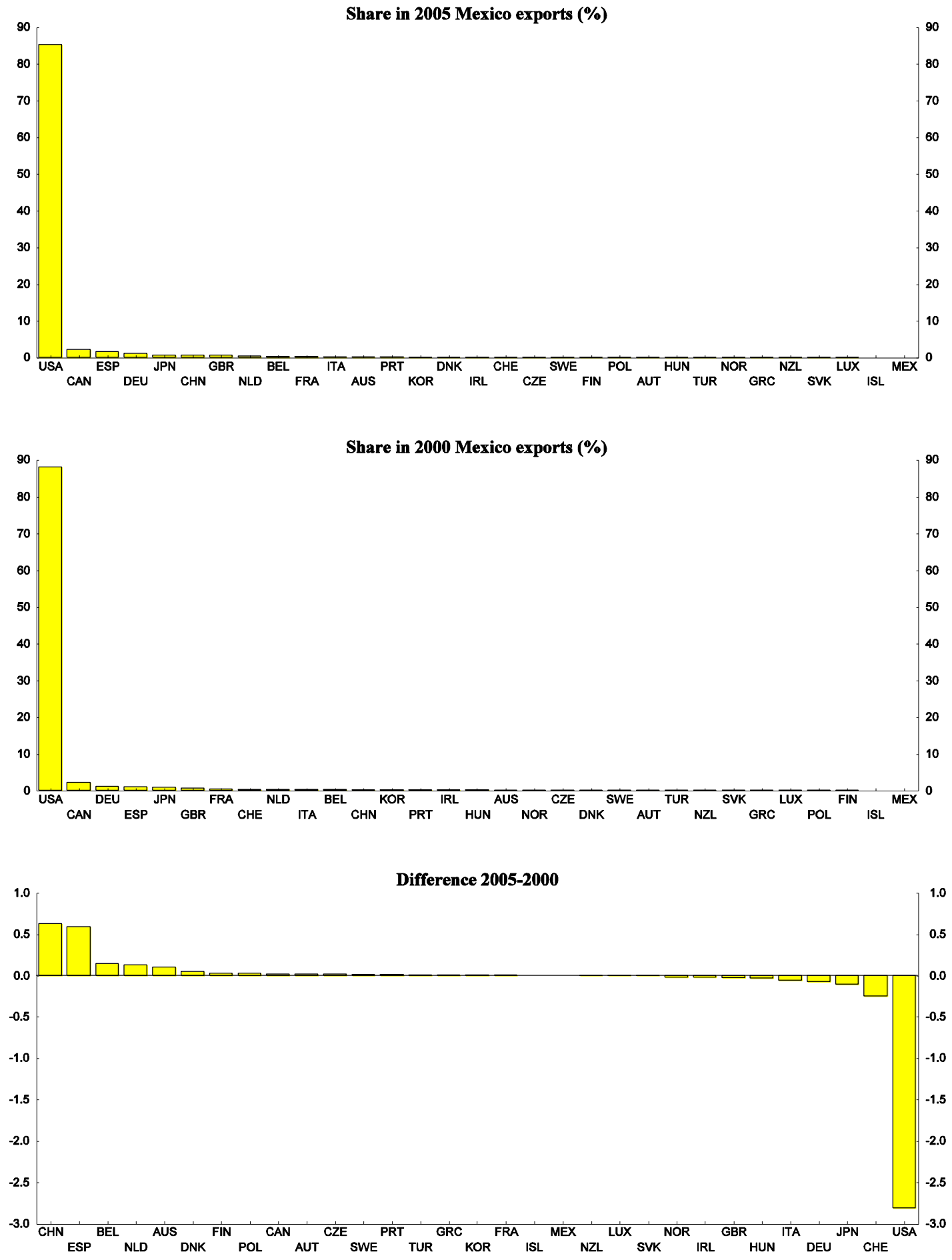
Figure A3.40 Mexico import breakdown by origin
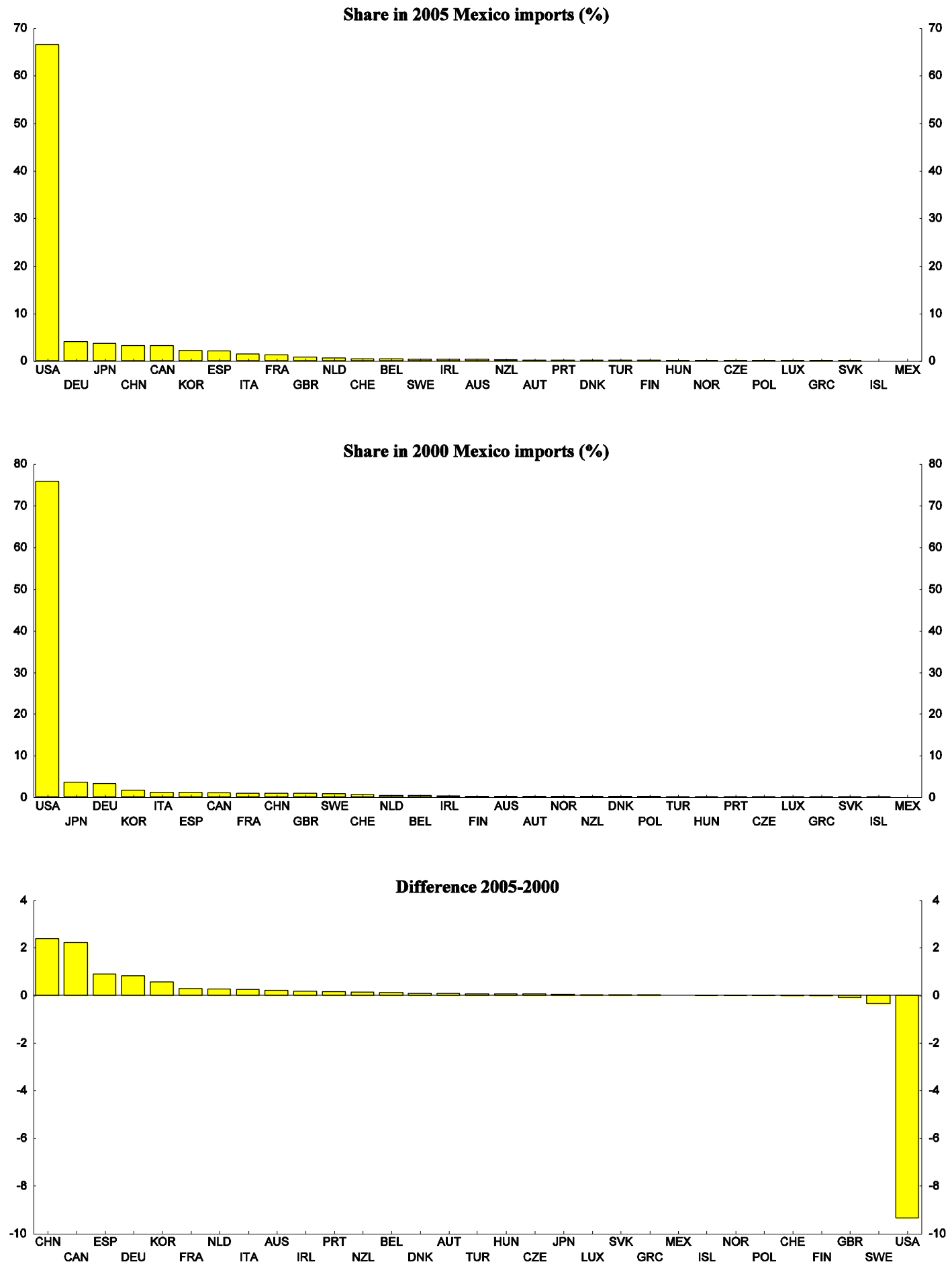
Figure A3.41 Netherlands export breakdown by destination
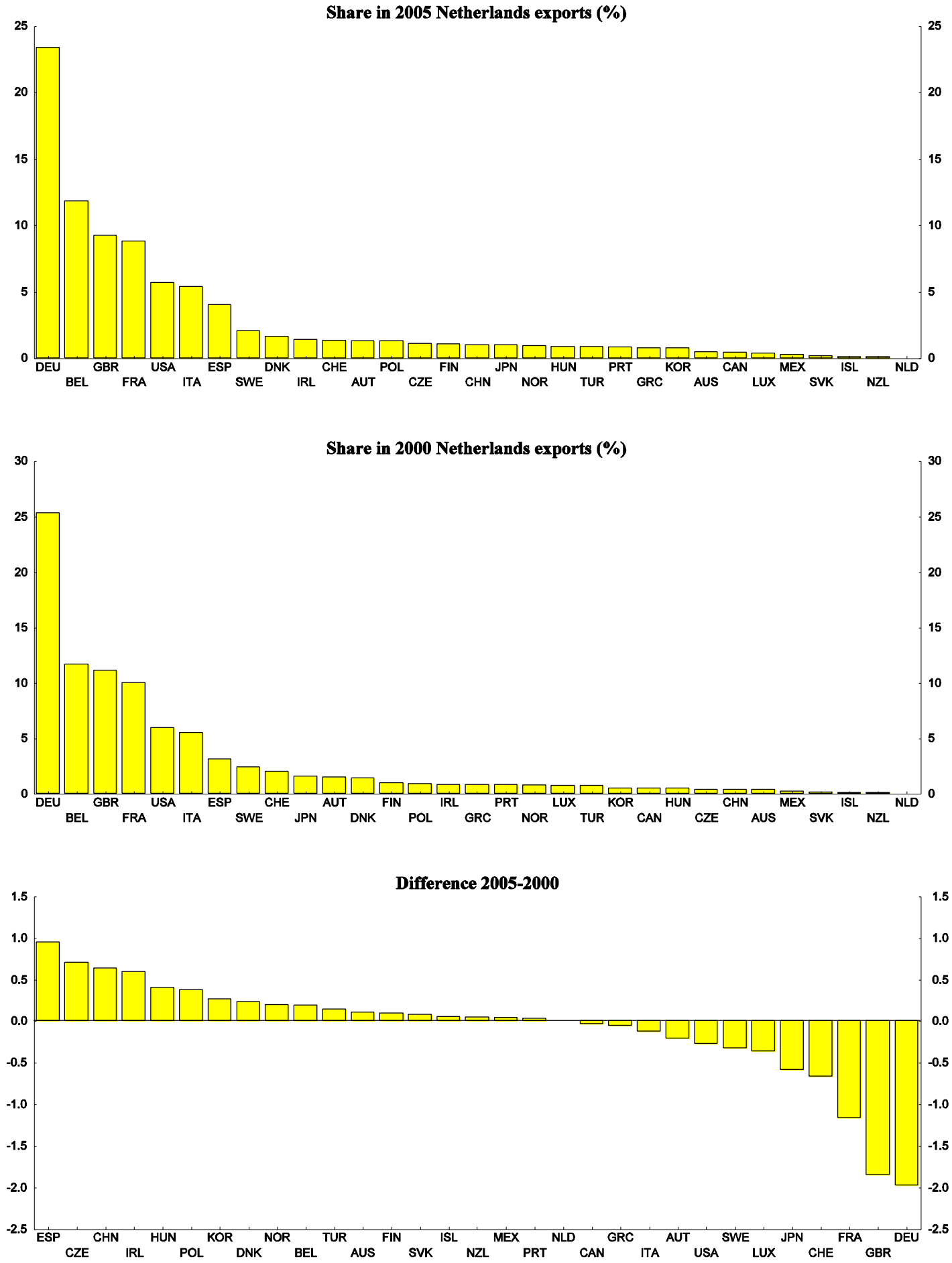
Figure A3.42 Netherlands import breakdown by origin
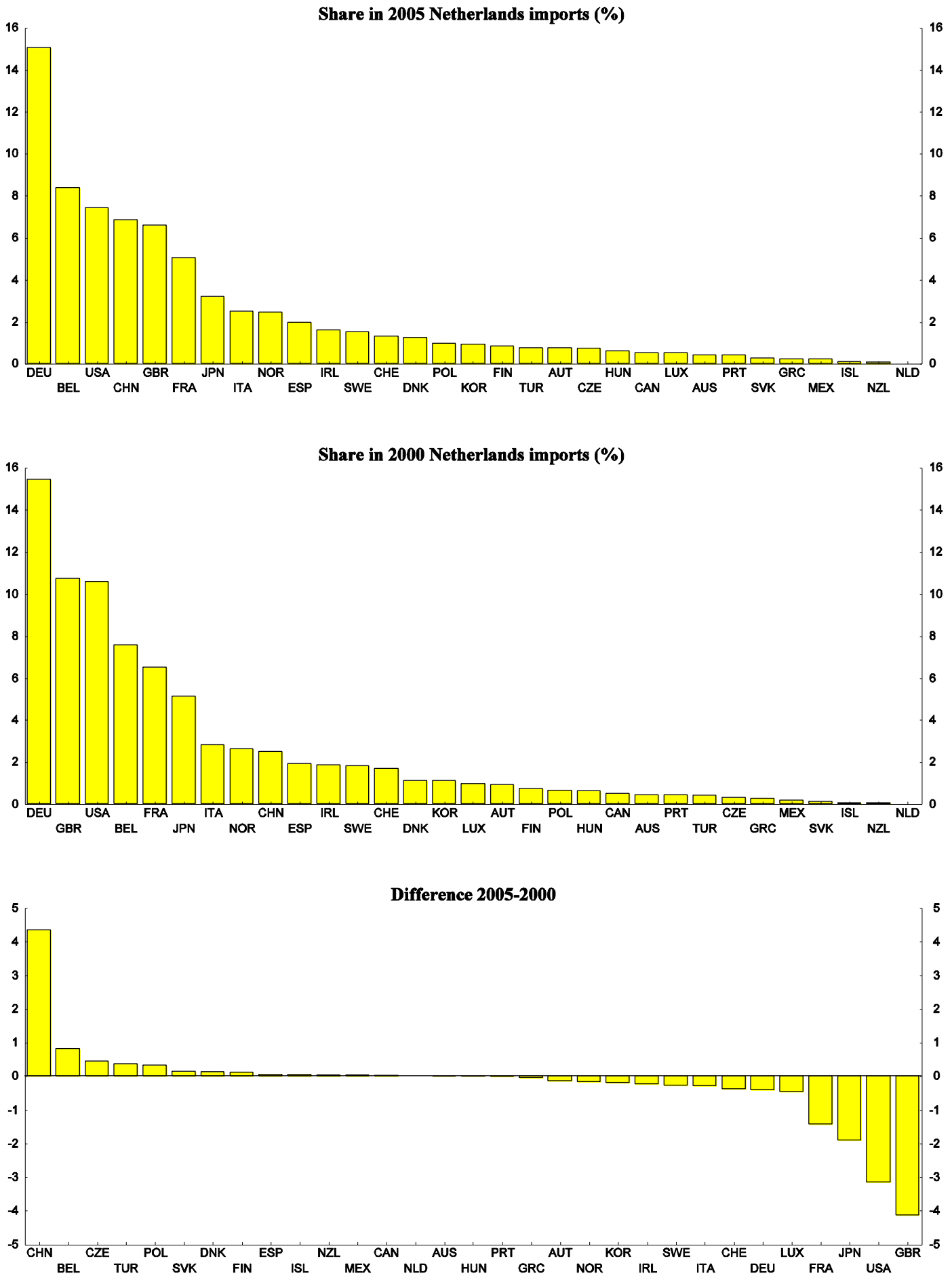
Figure A3.43 New Zealand export breakdown by destination
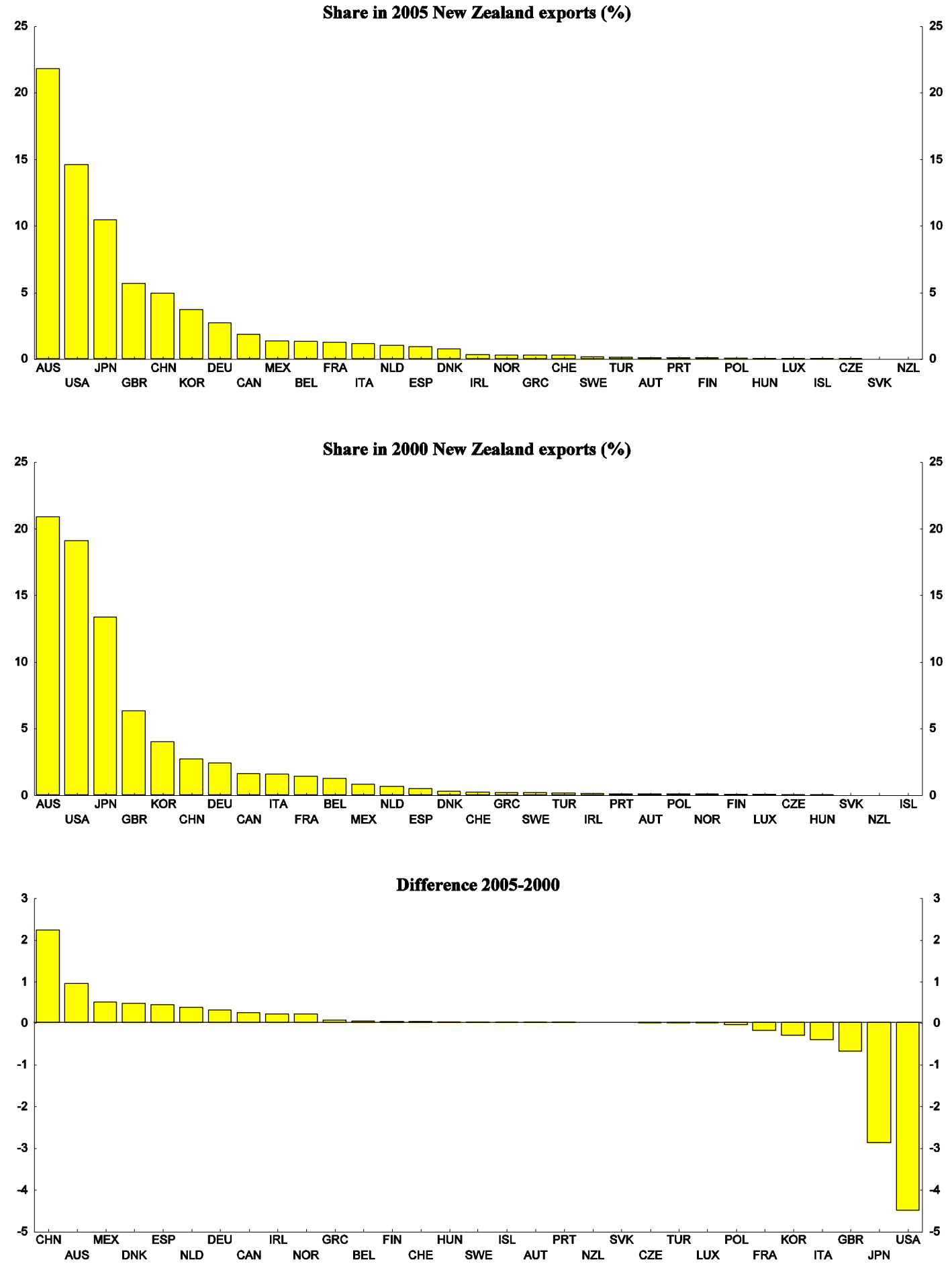
Figure A3.44 New Zealand import breakdown by origin

Share in 2005 New Zealand imports (\%)
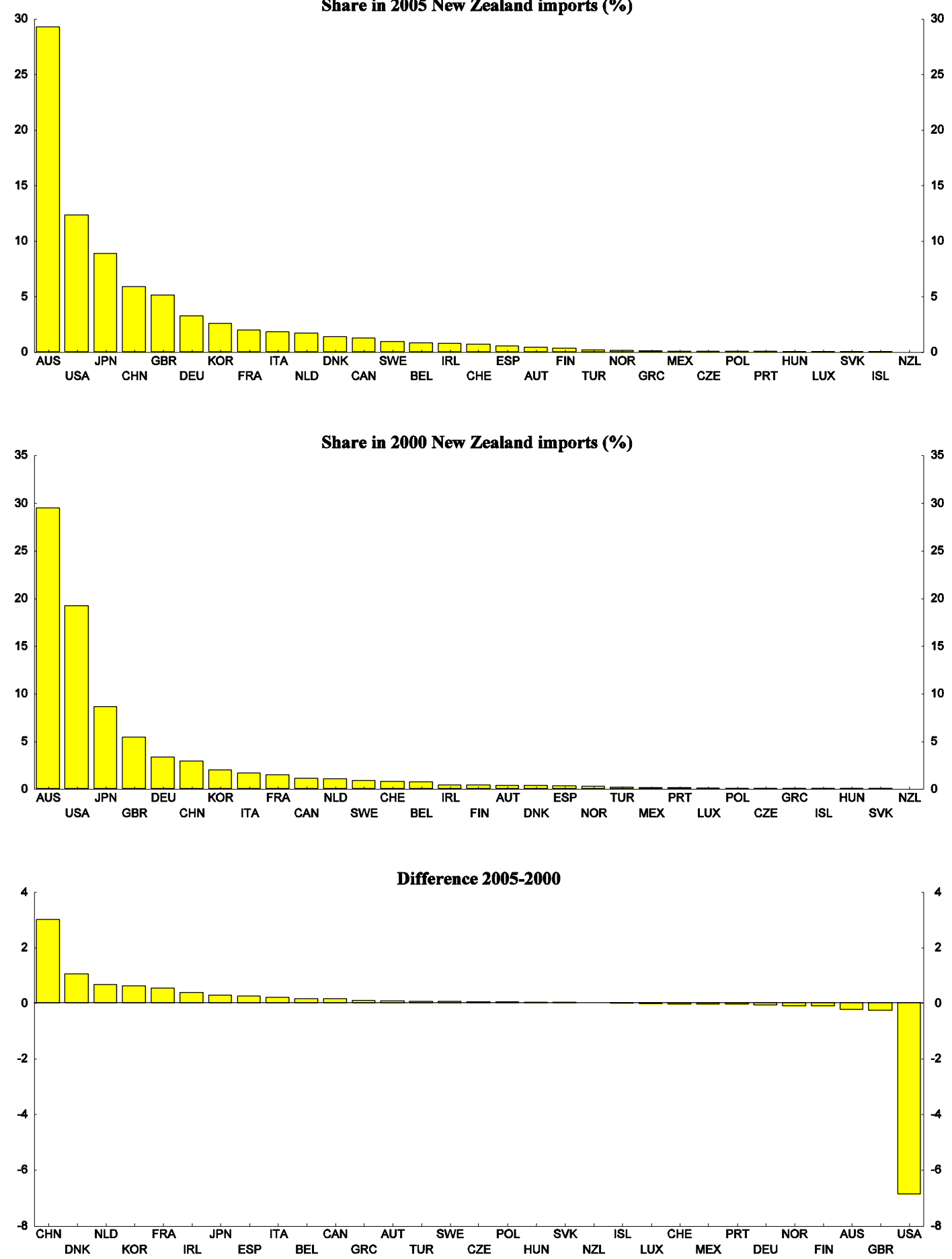
Figure A3.45 Norway export breakdown by destination
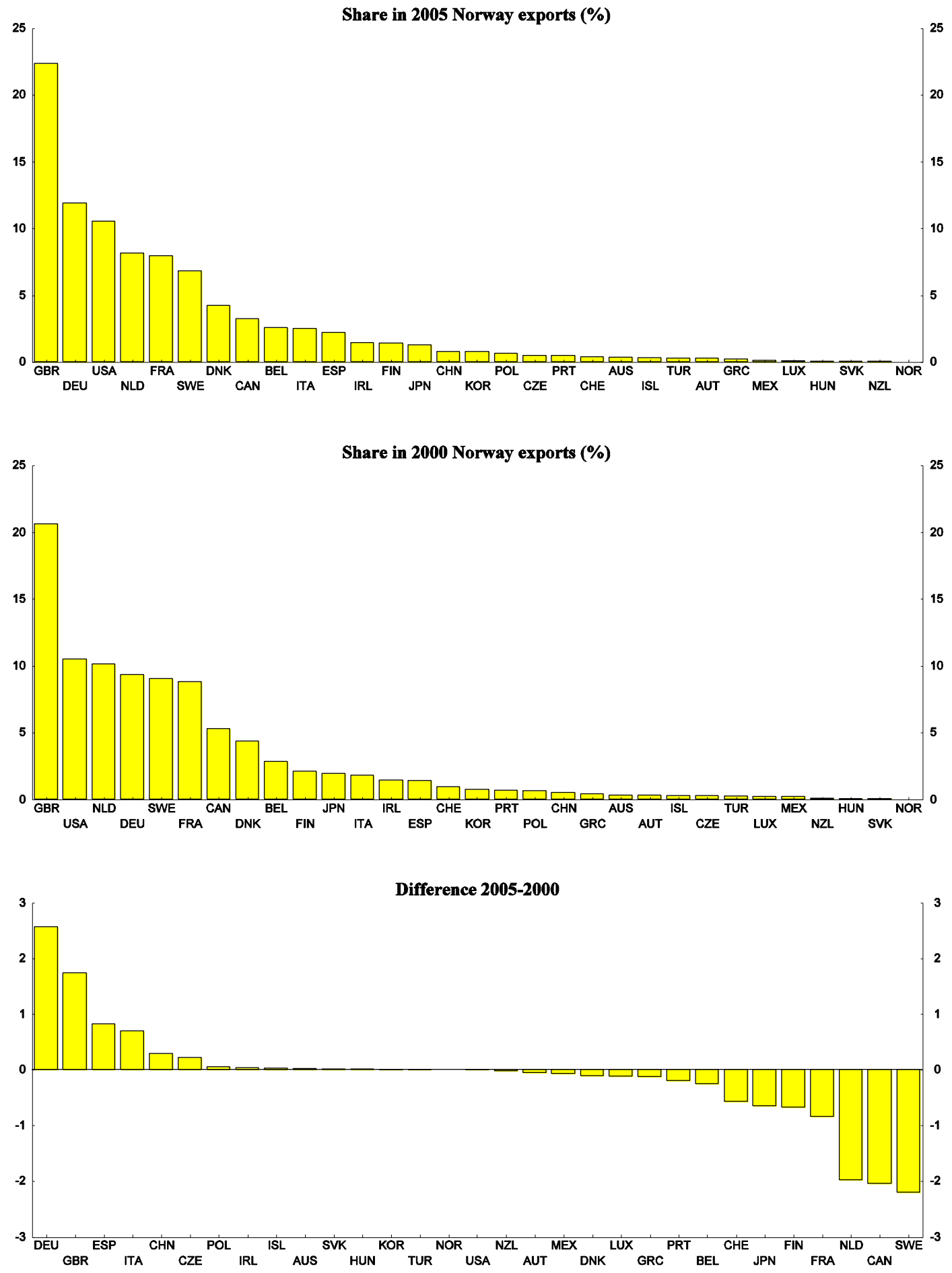
Figure A3.46 Norway import breakdown by origin
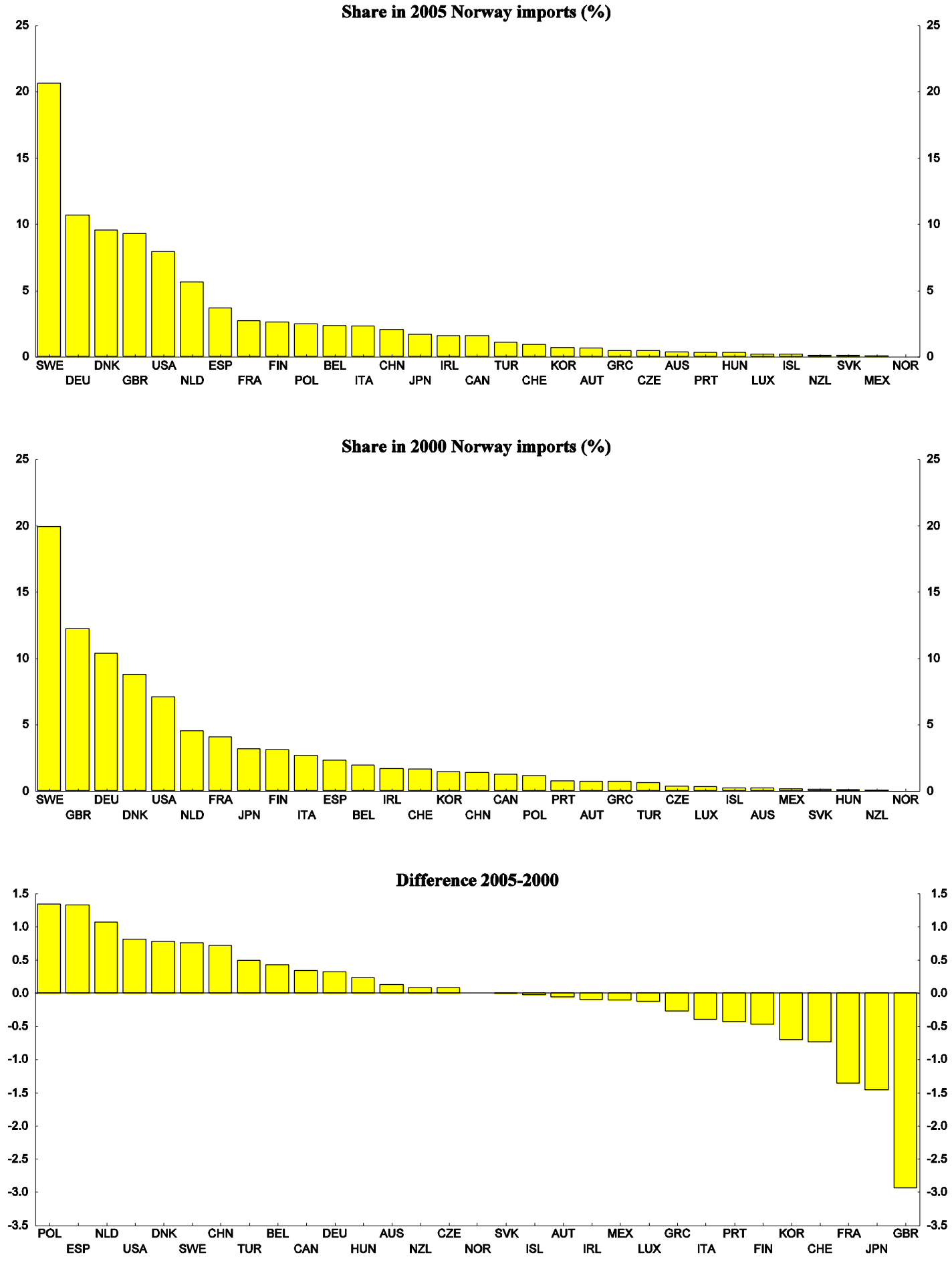
Figure A3.47 Poland export breakdown by destination
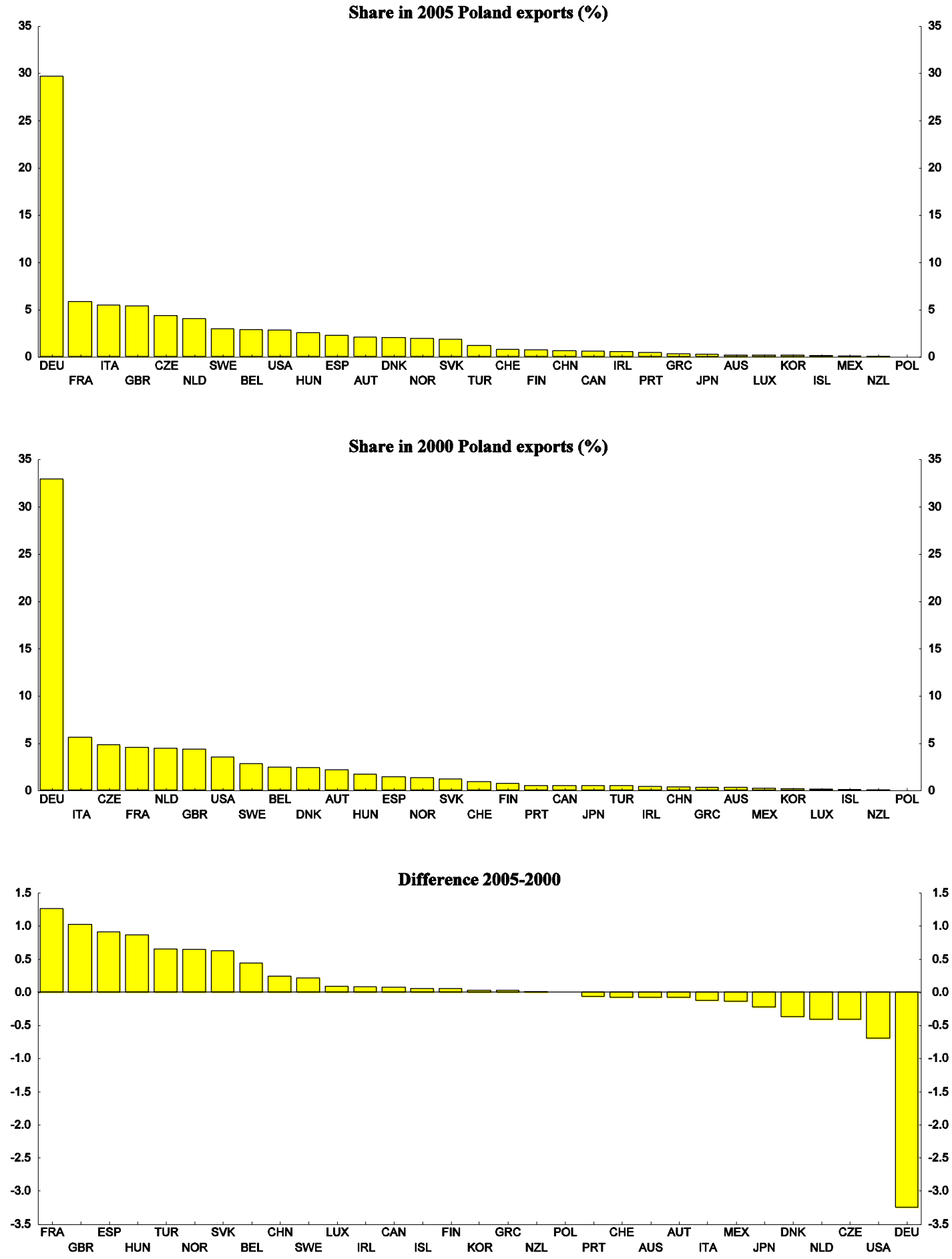
Figure A3.48 Poland import breakdown by origin
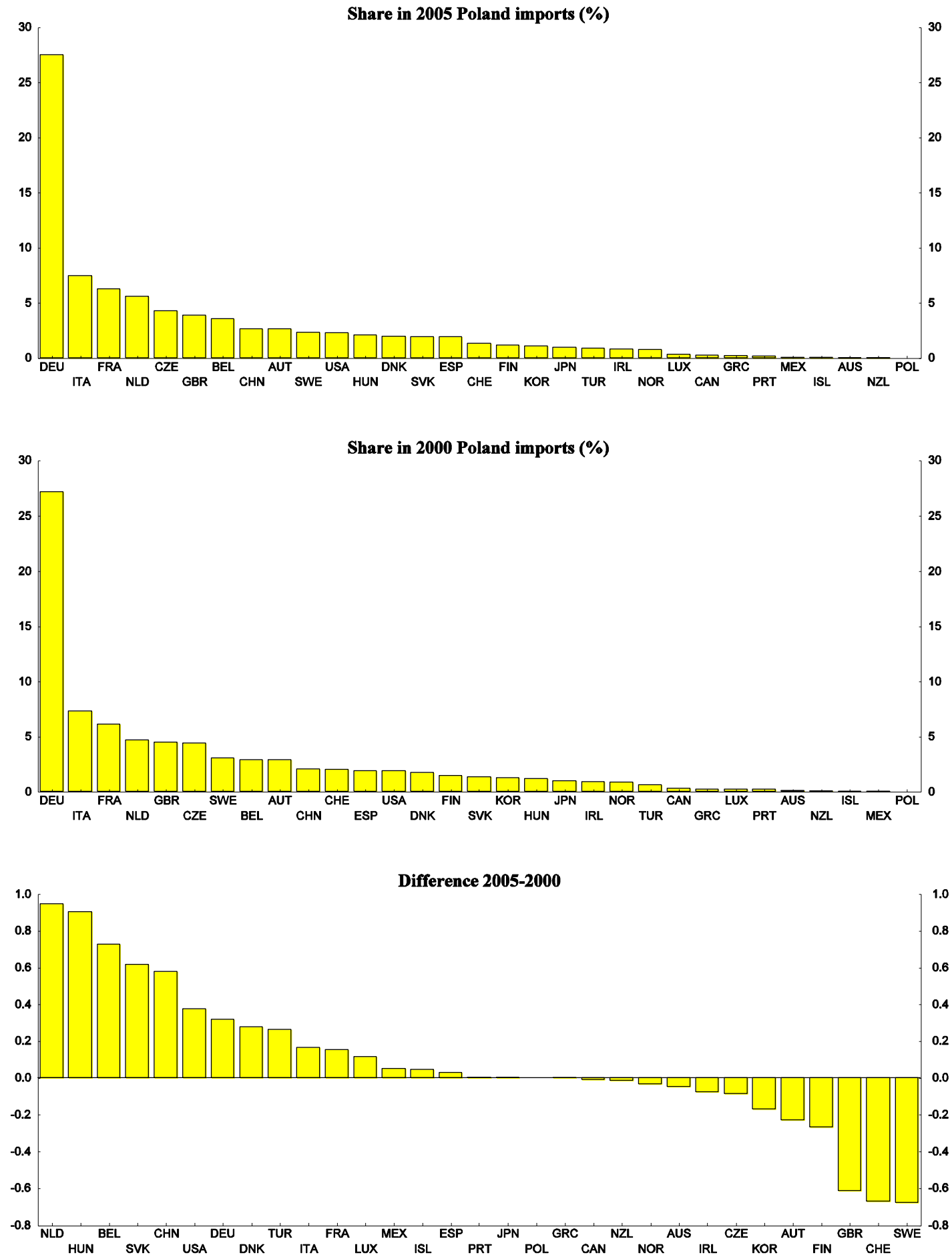
Figure A3.49 Portugal export breakdown by destination
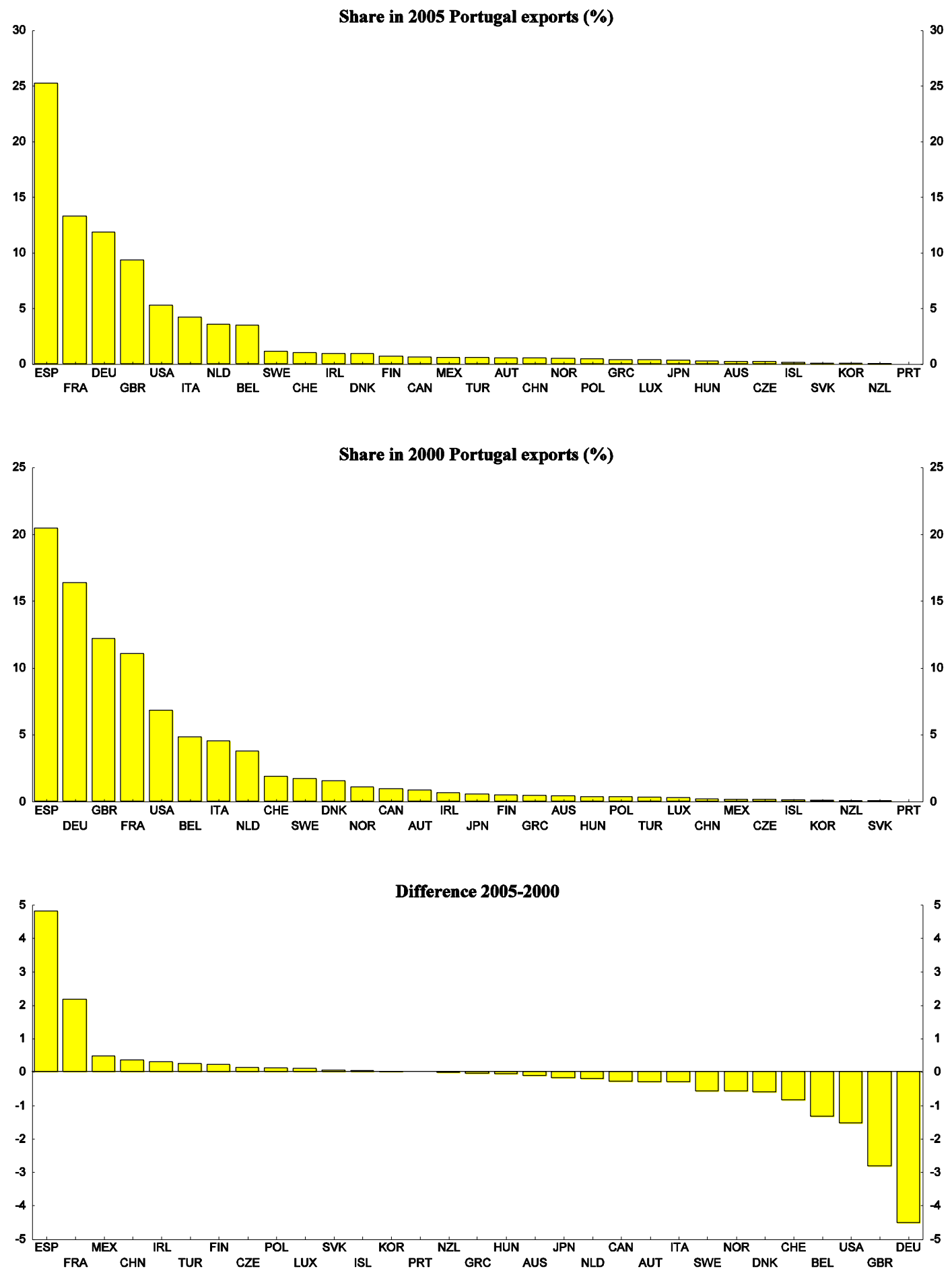
Figure A3.50 Portugal import breakdown by origin
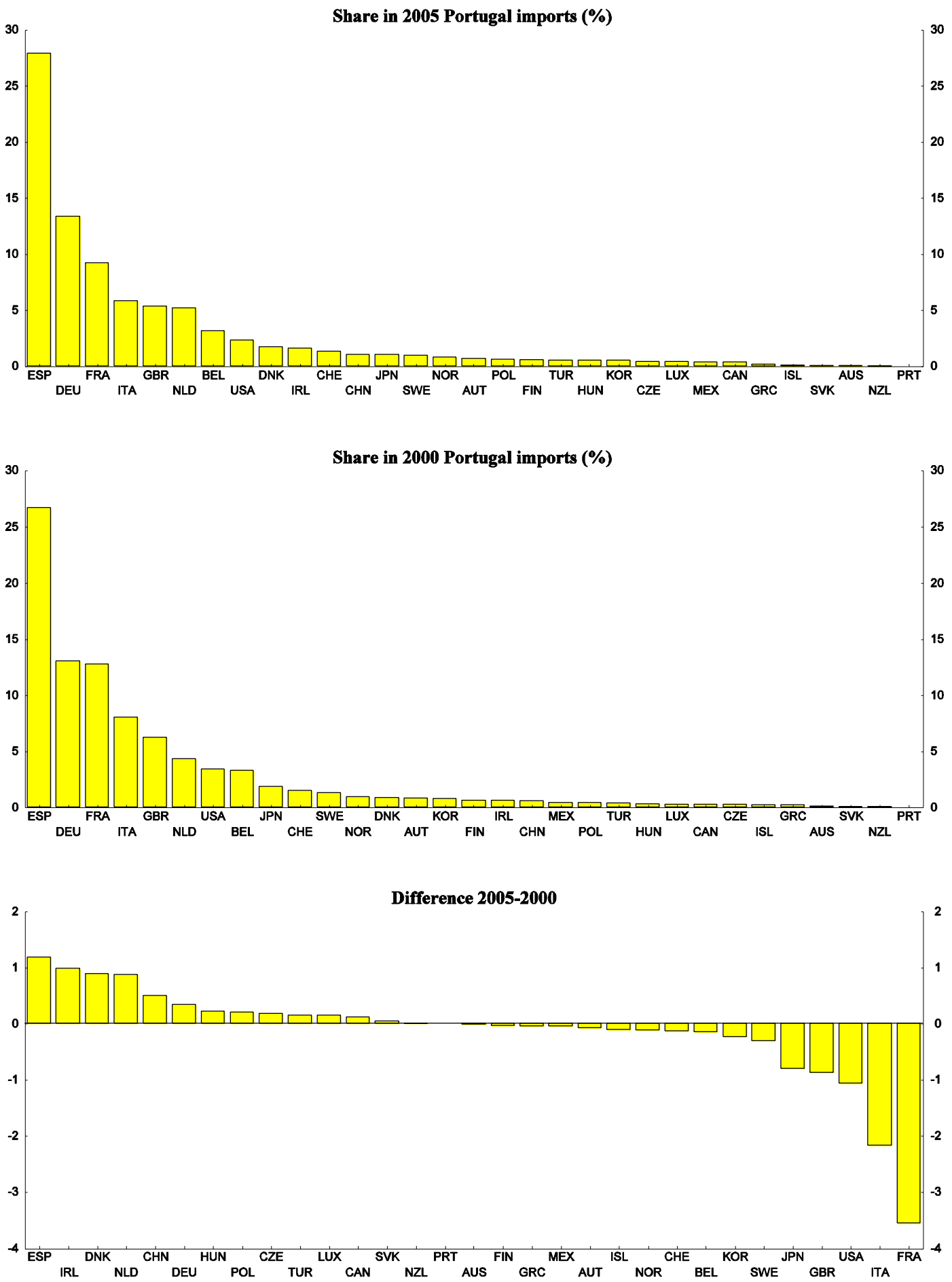
Figure A3.51 Slovak Republic export breakdown by destination
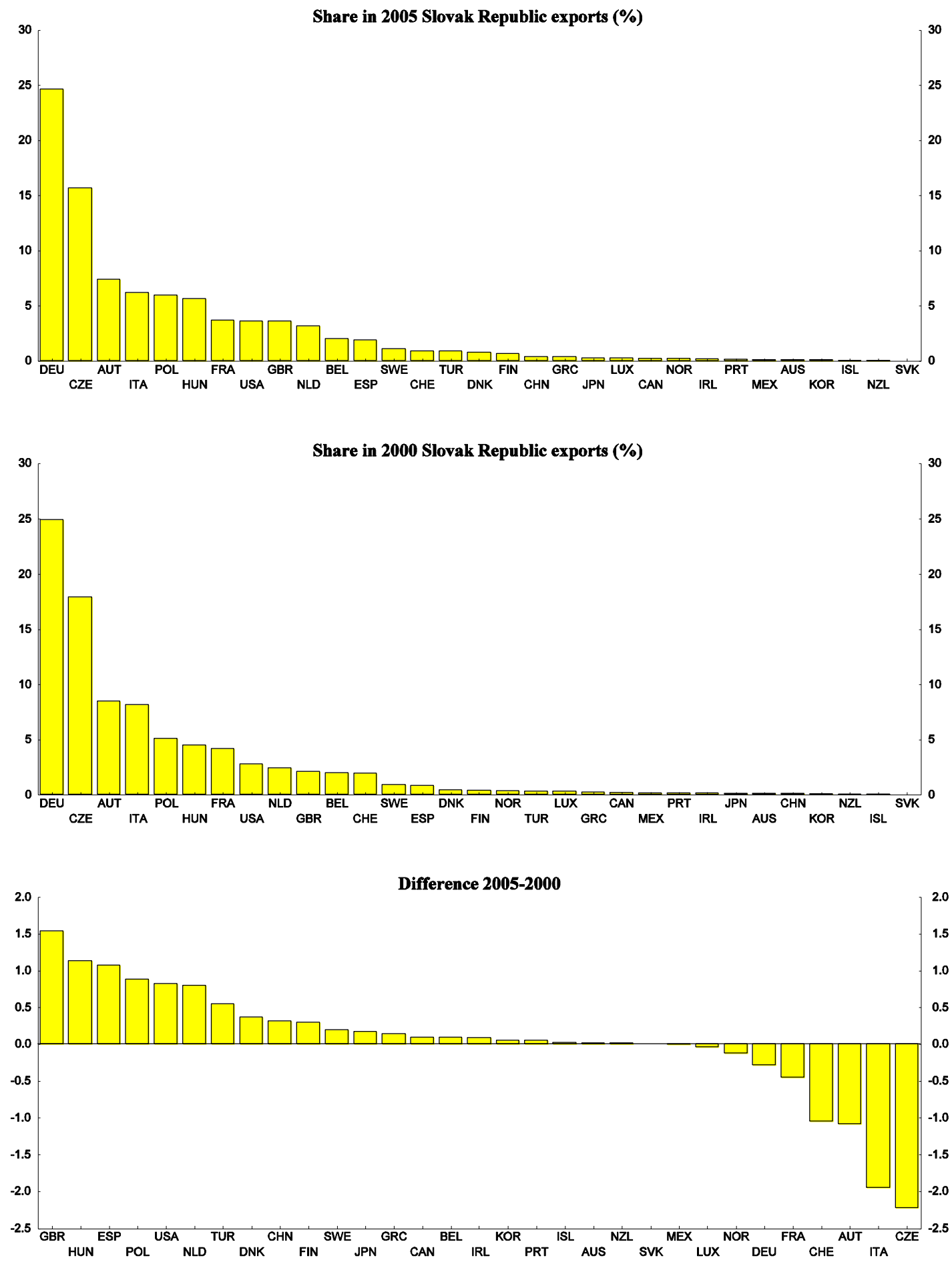
Figure A3.52 Slovak Republic import breakdown by origin
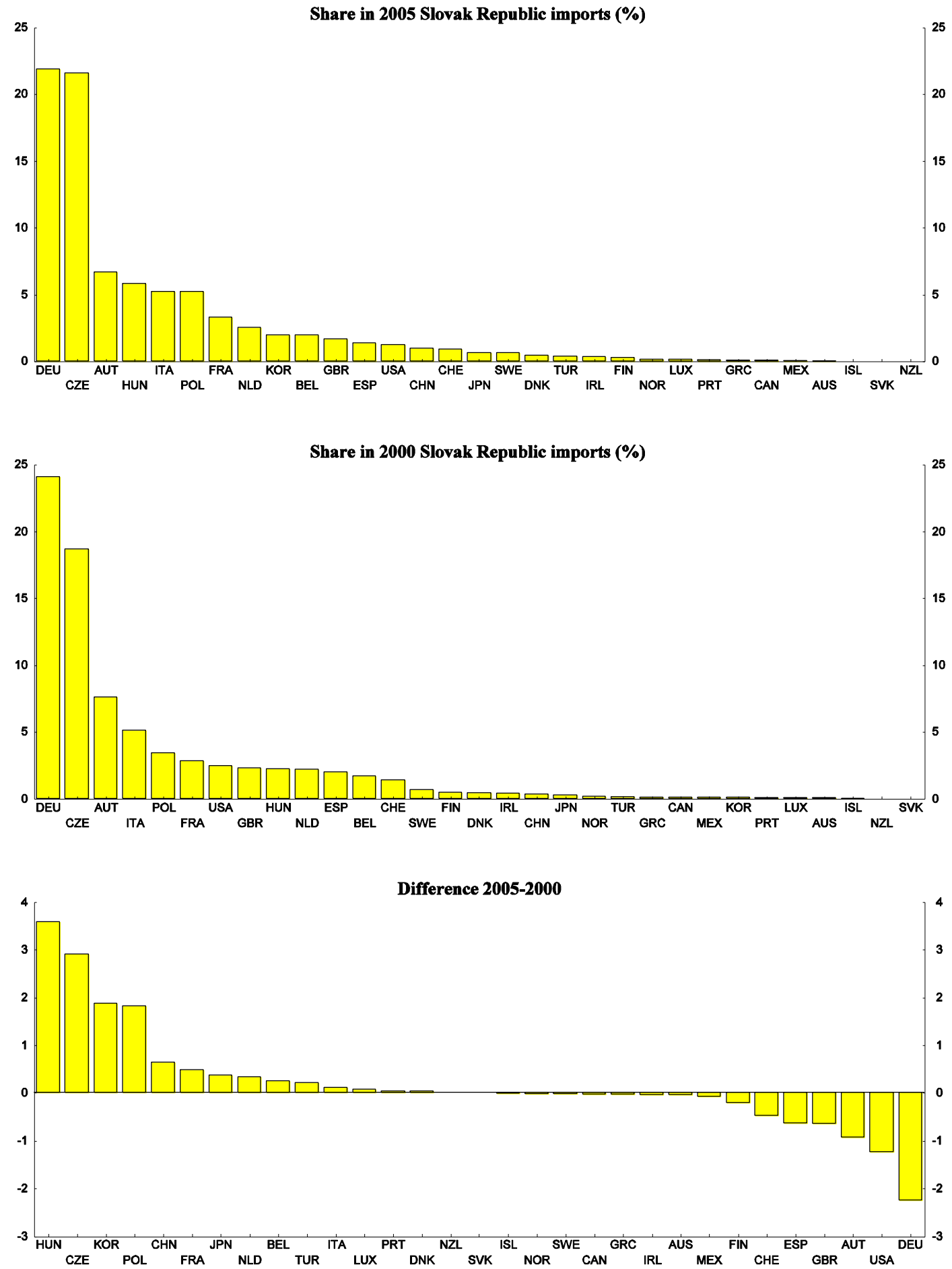
Figure A3.53 Spain export breakdown by destination
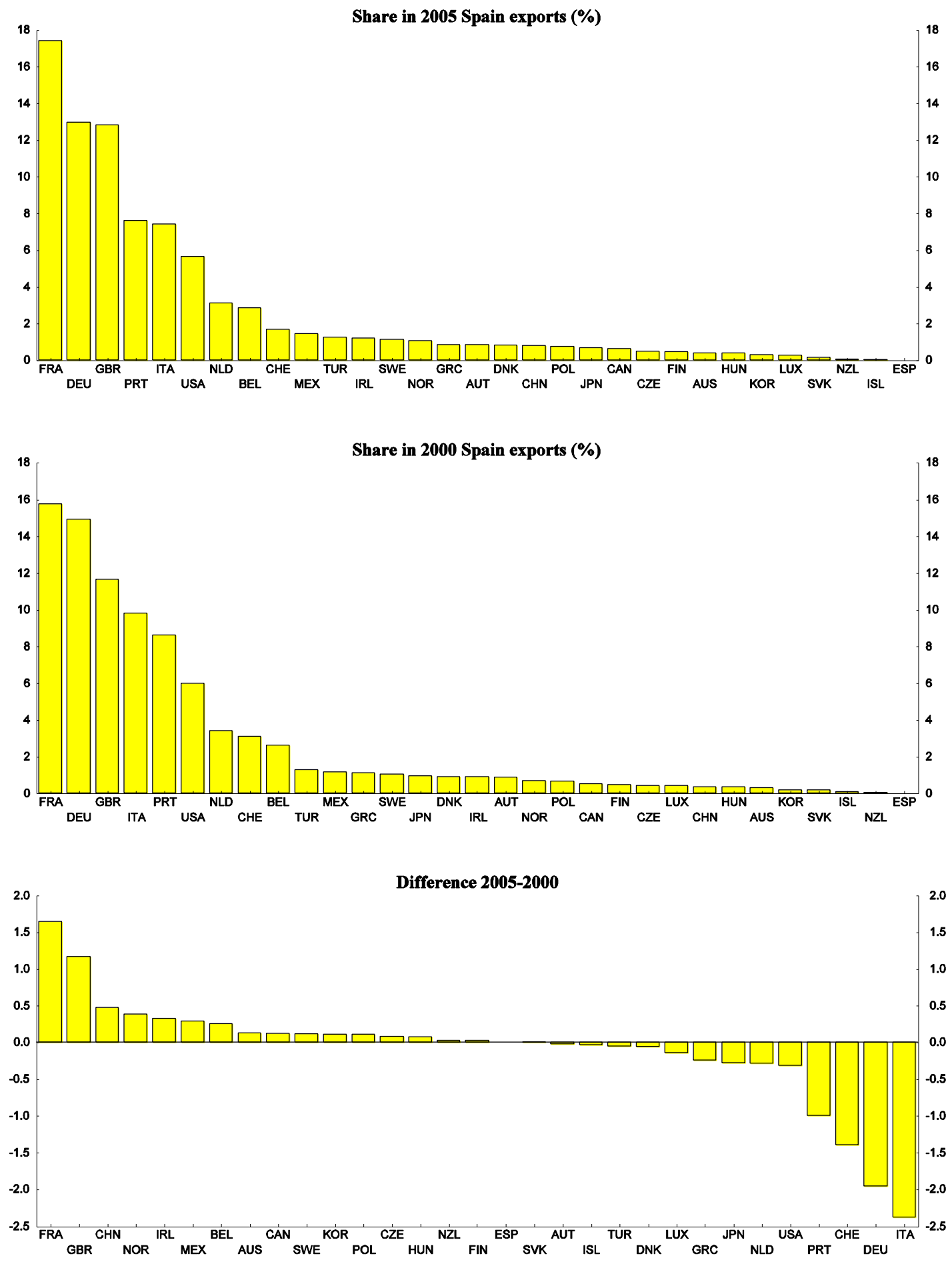
Figure A3.54 Spain import breakdown by origin

Share in 2005 Spain imports (\%)
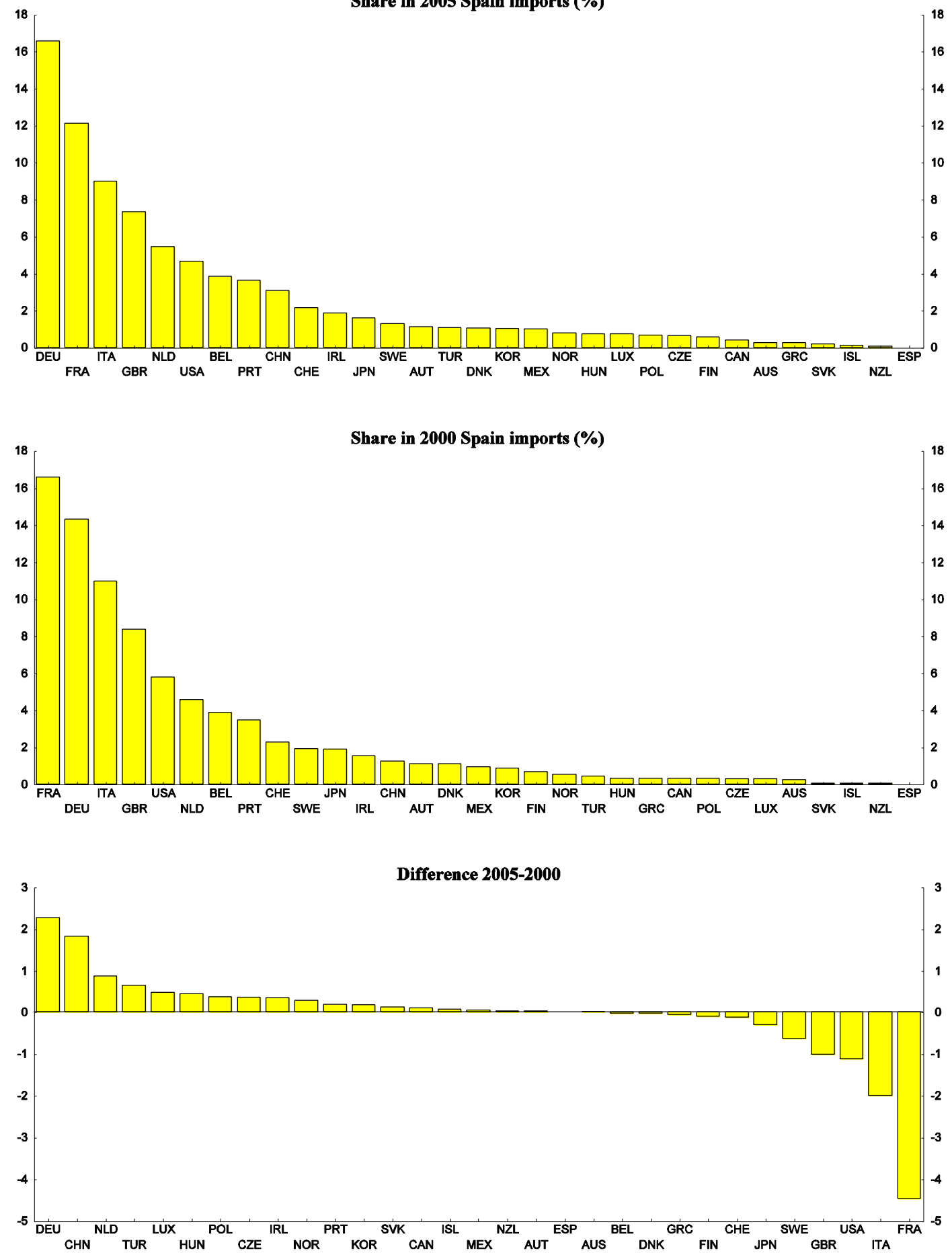
Figure A3.55 Sweden export breakdown by destination
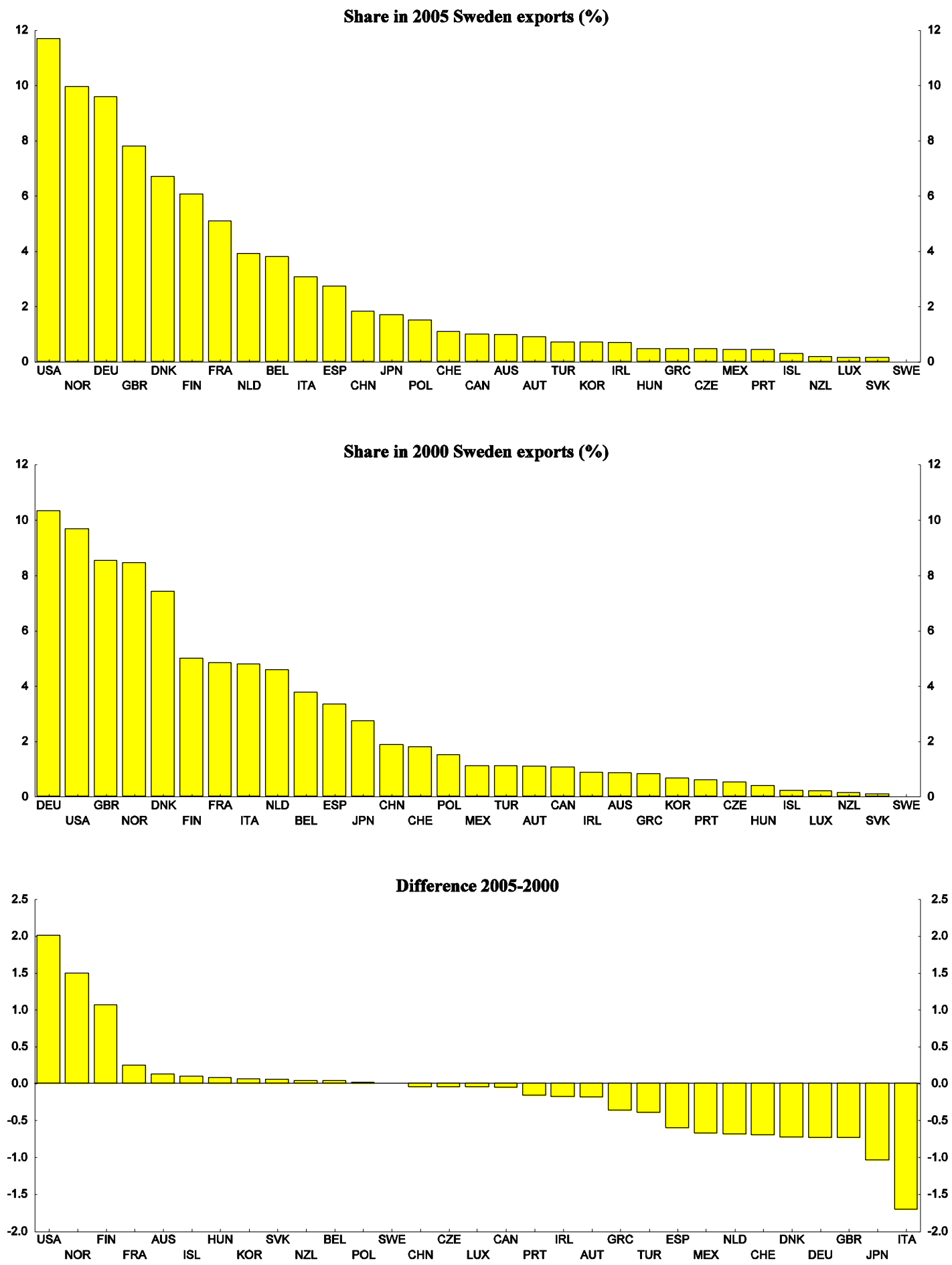
Figure A3.56 Sweden import breakdown by origin
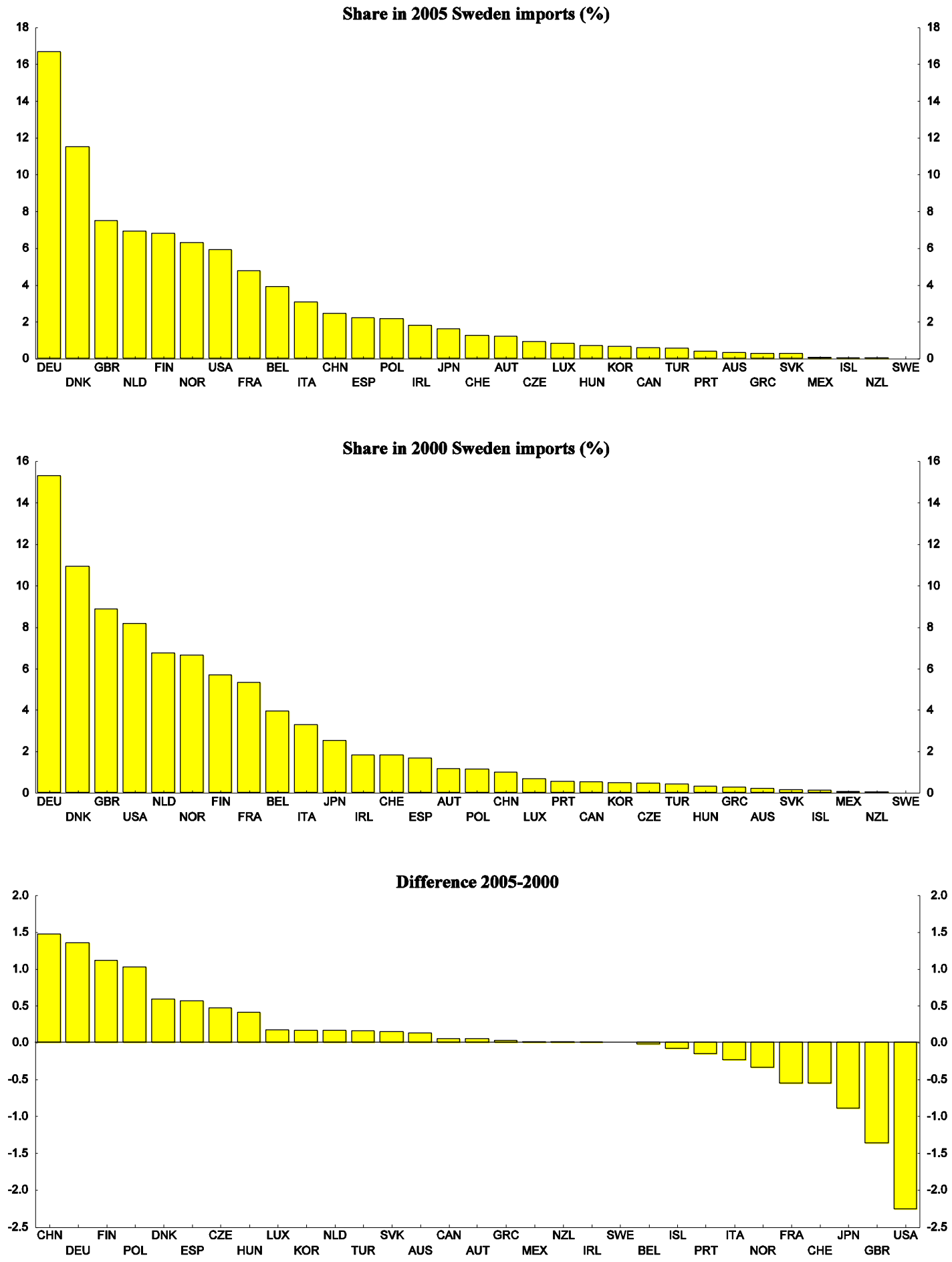
Figure A3.57 Switzerland export breakdown by destination
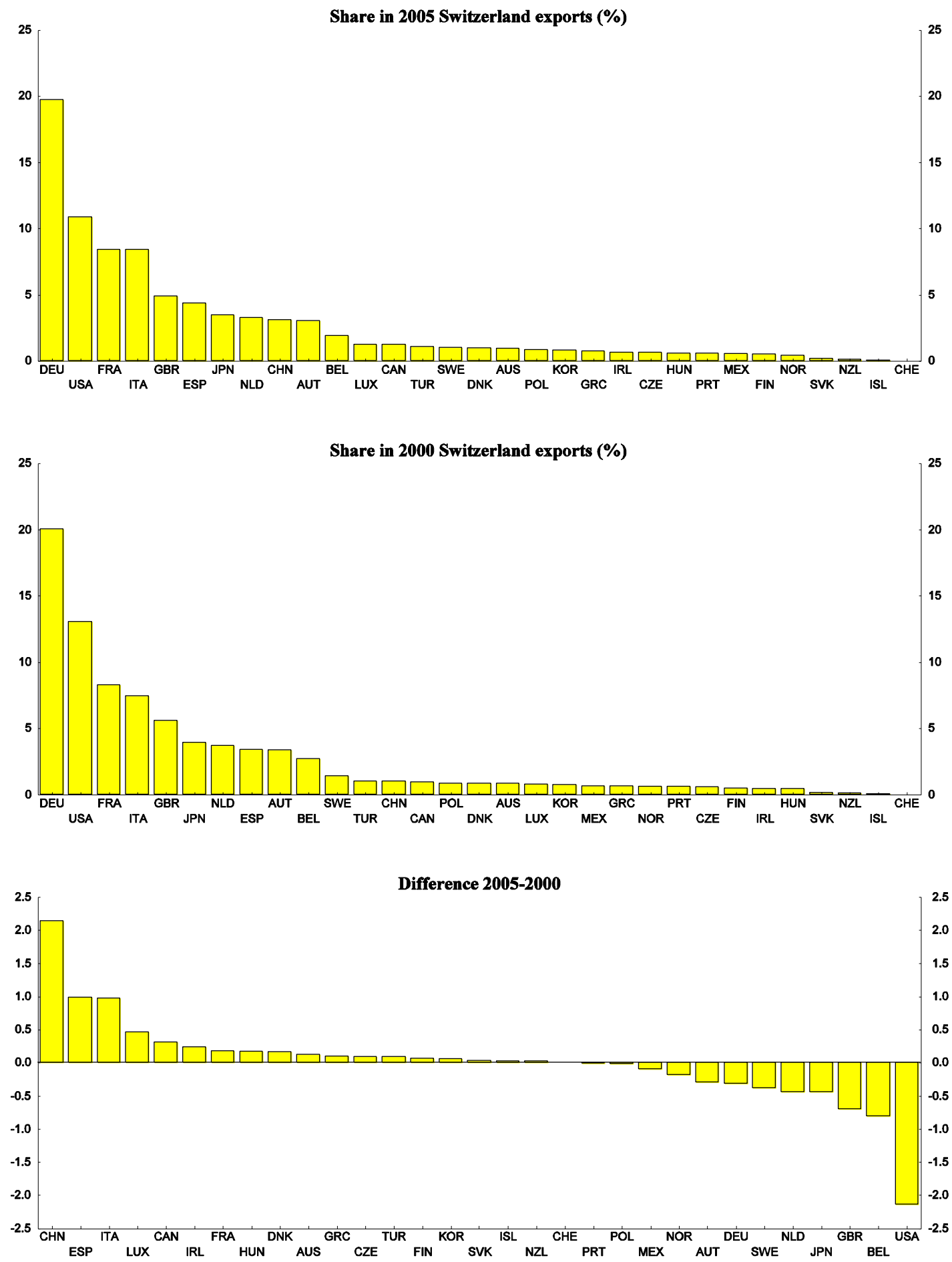
Figure A3.58 Switzerland import breakdown by origin
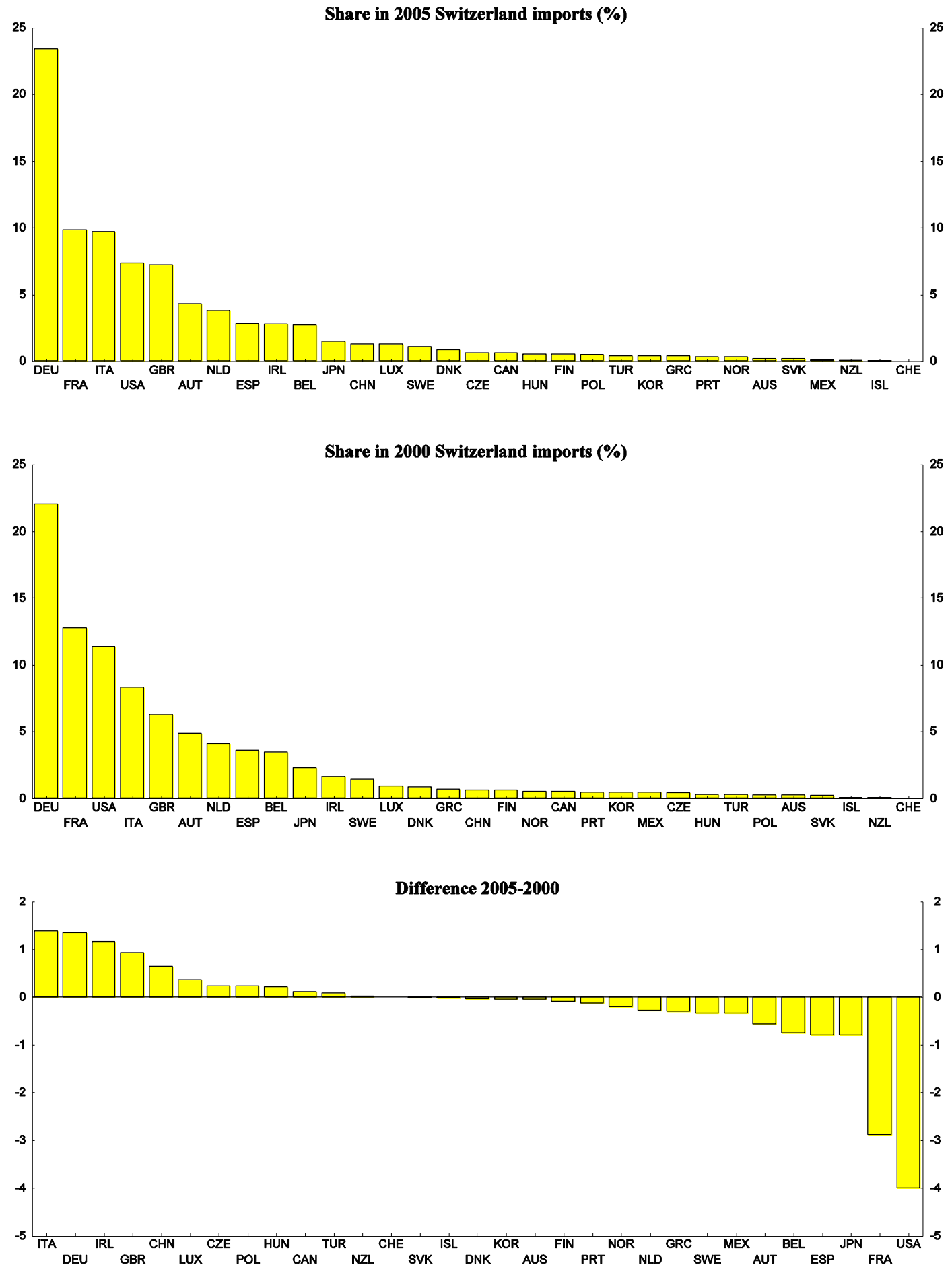
Figure A3.59 Turkey export breakdown by destination
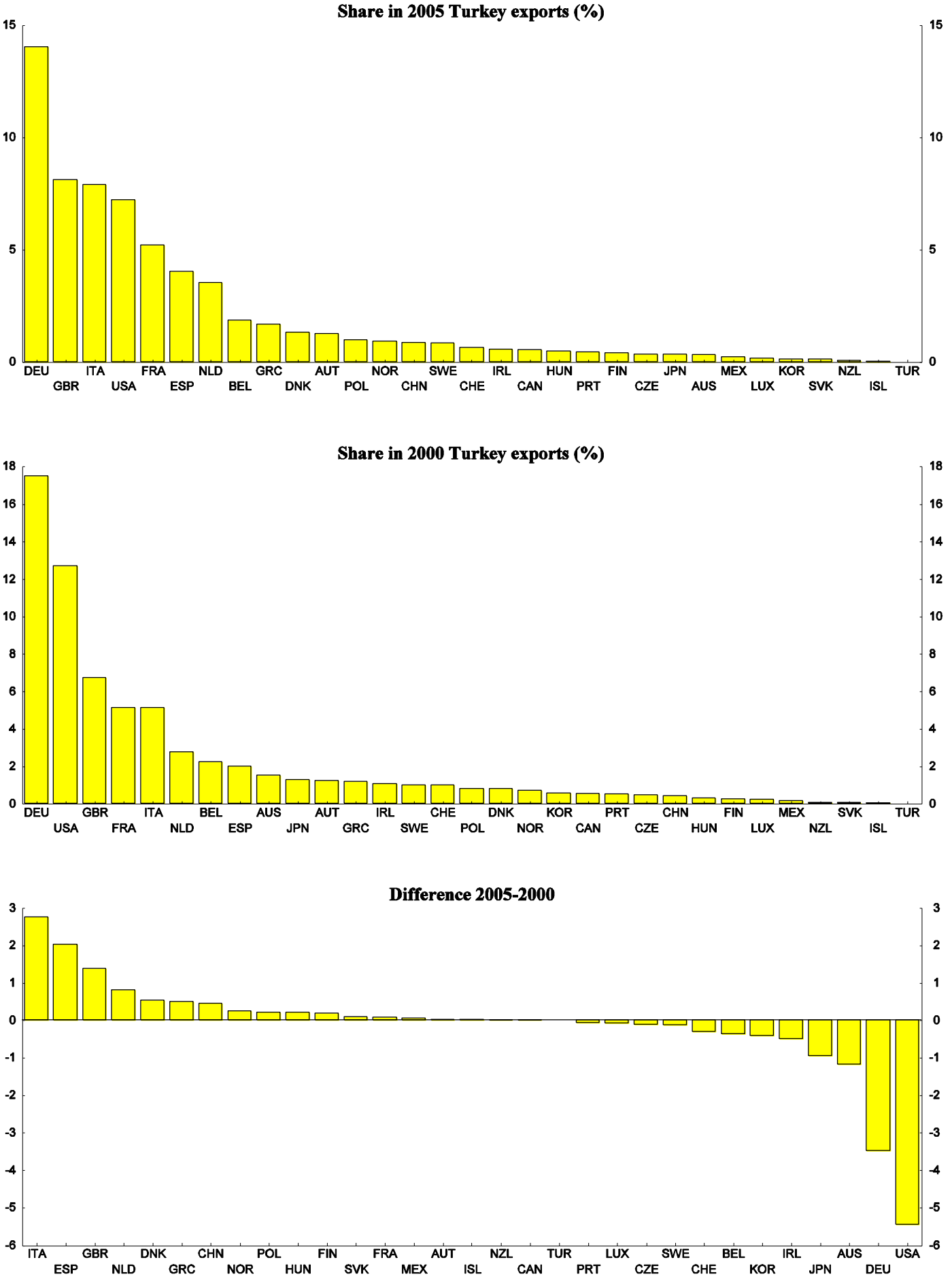
Figure A3.60 Turkey import breakdown by origin
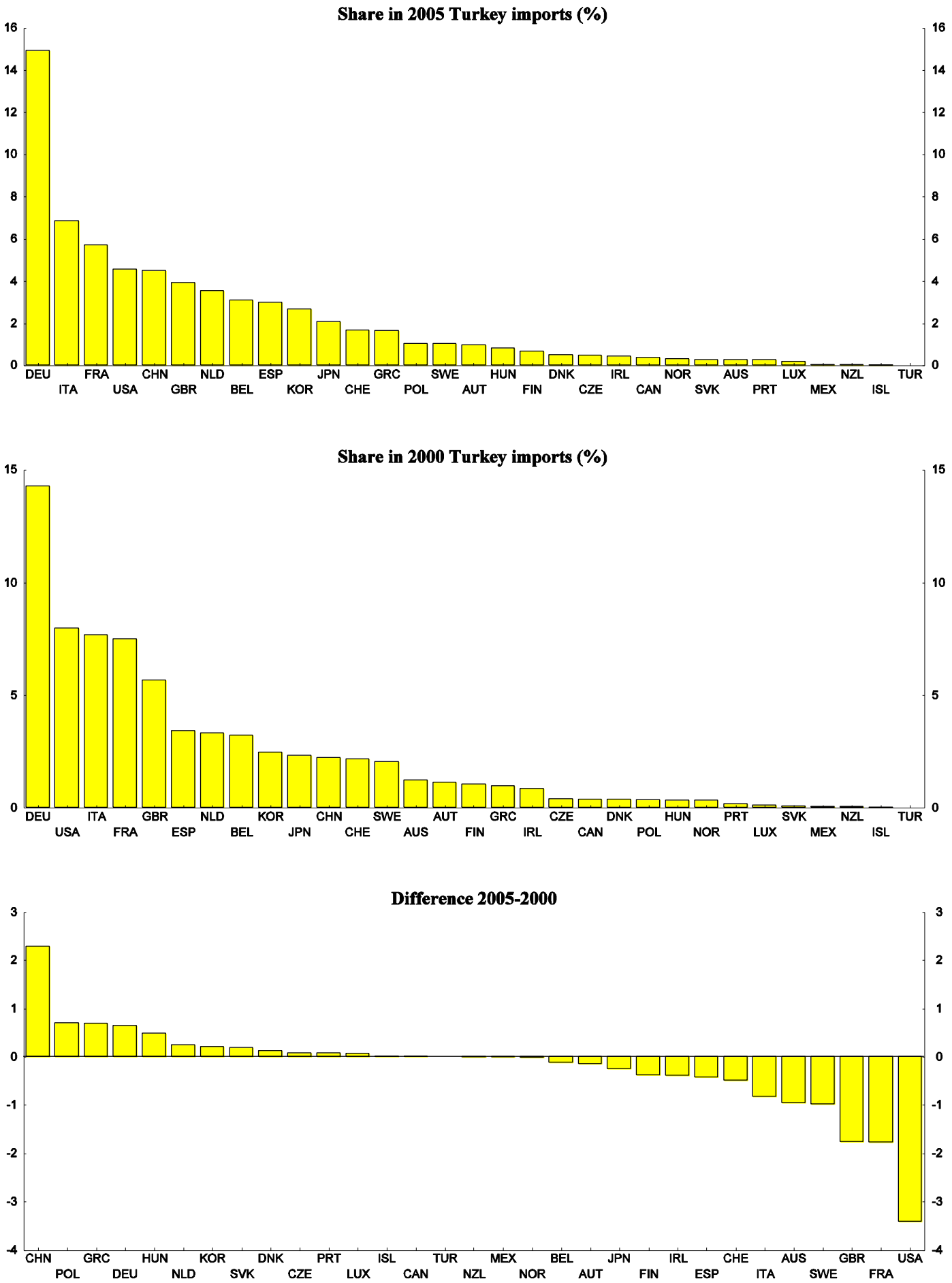
Figure A3.61 China export breakdown by destination

Share in 2005 China exports (\%)
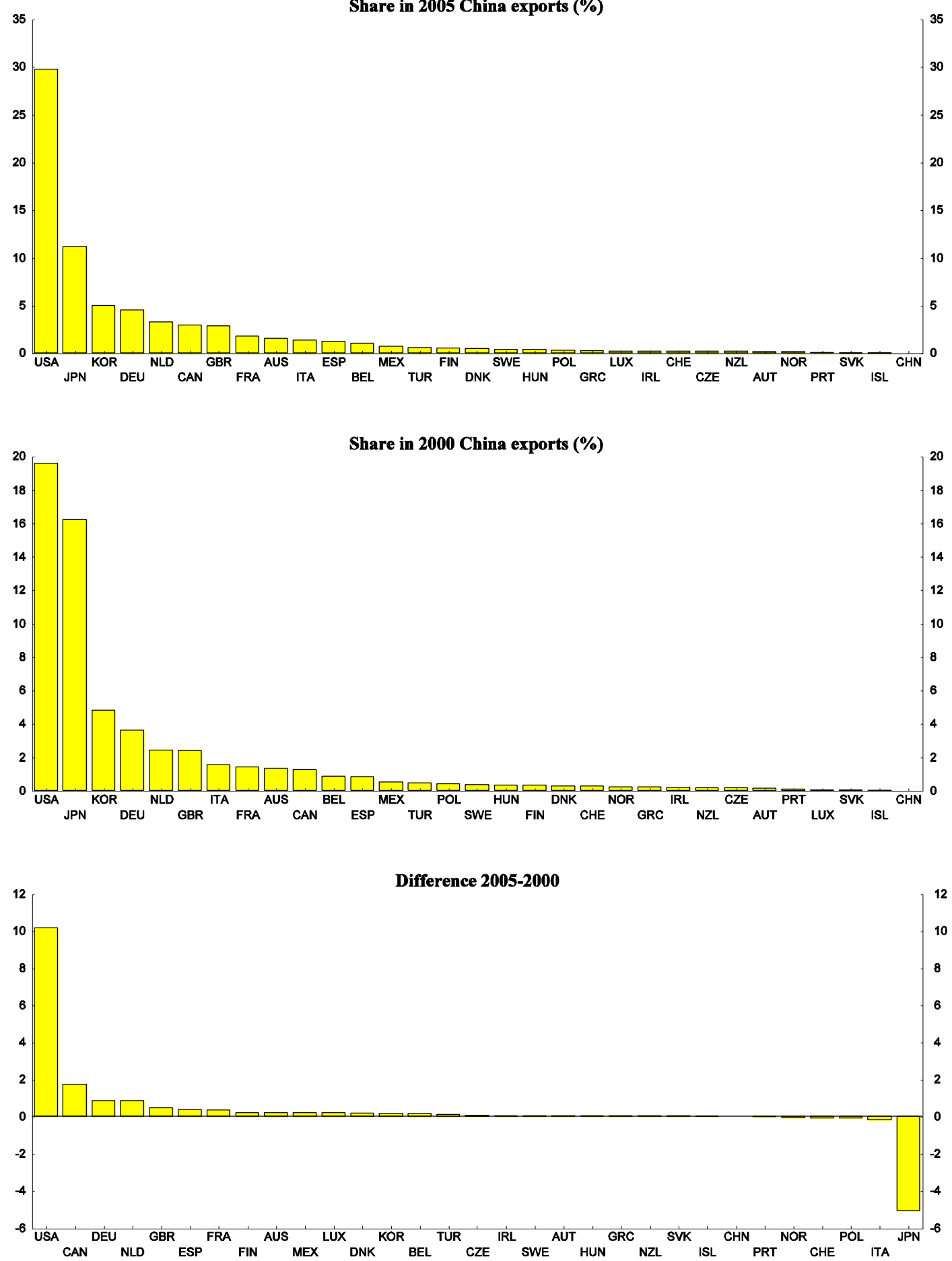
Figure A3.62 China import breakdown by origin

Share in 2005 China imports (\%)
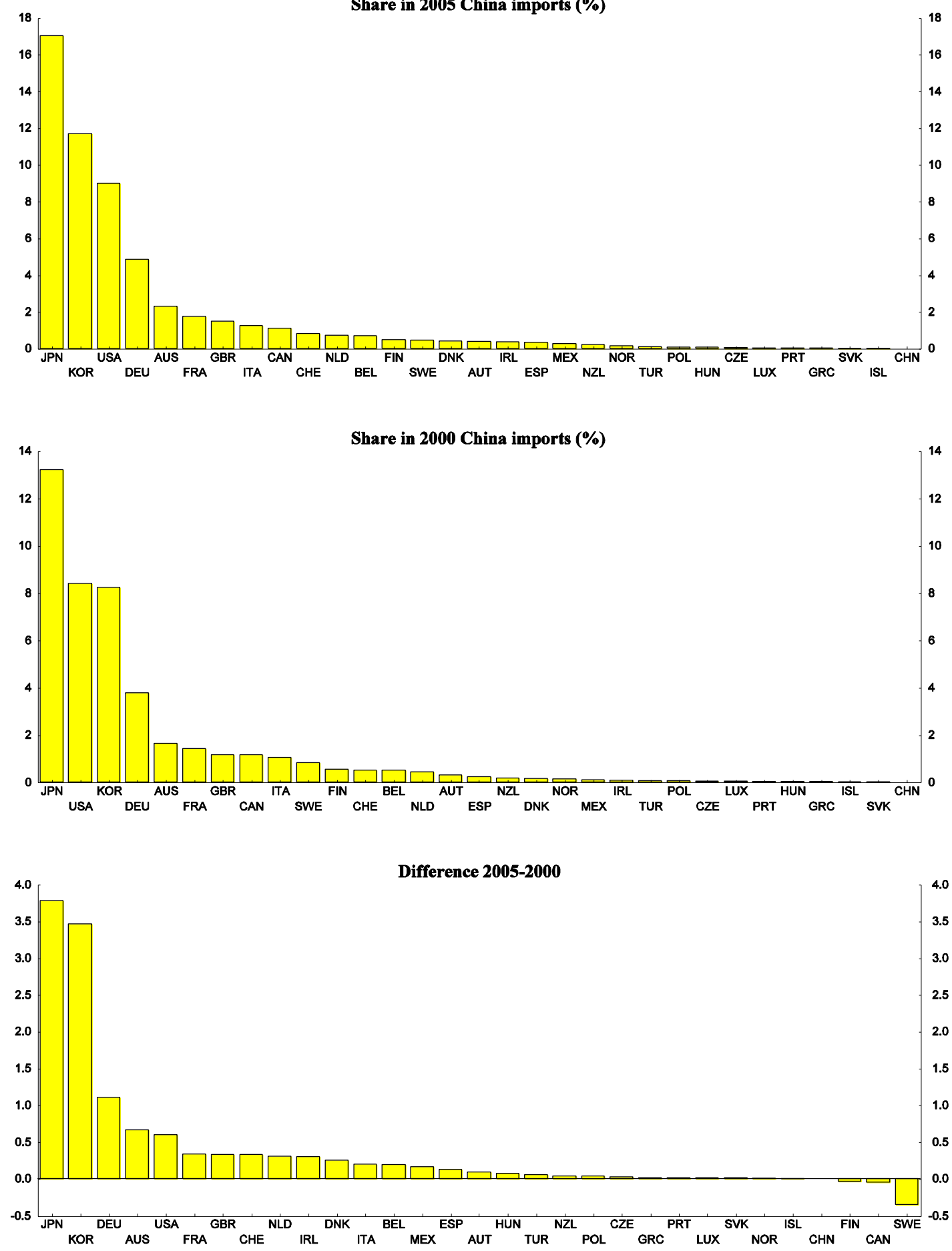


\section{WORKING PAPERS}

The full series of Economics Department Working Papers can be consulted at www.oecd.org/eco/workingpapers/

810. Enhancing the effectiveness of social policies in Indonesia

(October 2010) by Margherita Comola and Luiz de Mello

809. Tackling the infrastructure challenge in Indonesia

(October 2010) by Mauro Pisu

808. Phasing out energy subsidies in Indonesia

(October 2010) by Annabelle Mourougane

807. Implementing cost-effective policies in the United States to mitigate climate change (October 2010) by David Carey

806. Restoring fiscal sustainability in the United States

(October 2010) by Patrick Lenain, Bob Hagemann and David Carey

805. Norway: Sustainable development: climate change and fisheries policies (September 2010) by Paul O'Brien

804. Netherlands: How the transport system can contribute to better economic and environmental outcomes

(September 2010) by Tomasz Koźluk

803. Public-private partnerships and investment in infrastructure (September 2010) by Sónia Araújo and Douglas Sutherland

802. Sustaining the momentum of fiscal reform

(September 2010) by Colin Forthun and Robert Hagemann

801. The consequences of banking crises for public debt (September 2010) by Davide Furceri and Aleksandra Zdzienicka

800. A simulation model of federal, provincial and territorial government accounts for the analysis of fiscal-consolidation strategies in Canada

(September 2010) by Yvan Guillemette

799. Product market regulation: extending the analysis beyond OECD countries

(October 2010) by Anita Wölfl, Isabelle Wanner, Oliver Röhn, Giuseppe Nicoletti

798. Korea's green growth strategy: mitigating climate change and developing new growth engines (July 2010) by Randall S. Jones and Byungseo Yoo

797. Health-care reform in Korea (July 2010) by Randall S. Jones 


\section{ECO/WKP(2010)67}

796. The Korean financial system: overcoming the global financial crisis and addressing remaining problems

(July 2010) by Masahiko Tsutsumi, Randall S. Jones and Thomas F. Cargill

795. Are global imbalances sustainable? Post-crisis scenarios

(July 2010) by Luiz de Mello and Pier Carlo Padoan

794. Is there a case for carbon-based border tax adjustment? An applied general equilibrium analysis (July 2010) by Jean-Marc Burniaux, Jean Chateau and Romain Duval

793. Promoting potential growth: The role of structural reform

(July 2010) by Luiz de Mello and Pier Carlo Padoan

792. Catching-up and inflation in Europe: Balassa-Samuelson, Engel's law and other culprits (July 2010) by Balázs Égert

791. Do product market regulations in upstream sectors curb productivity growth? Panel data evidence for OECD countries (July 2010) by Renaud Bourlès, Gilbert Cette, Jimmy Lopez, Jacques Mairesse, Giuseppe Nicoletti

790. Preparing for Euro adoption in Poland

(July 2010) by Rafal Kierzenkowski

789. Gauging the impact of higher capital and oil costs on potential output (June 2010) by Boris Cournède

788. The German banking system: lessons from the financial crisis (June 2010) by Felix Hüfner

787. Measuring competition in Slovenian industries - estimation of mark-ups (June 2010) by Margit Molnar

786. Enhancing financial stability through better regulation in Hungary (June 2010) by Margit Molnar

785. Chile: Boosting productivity growth by strengthening competition, entrepreneurship and innovation (June 2010) by Cyrille Schwellnus

784. Chile: Climbing on giants' shoulders: better schools for all Chilean children (June 2010) by Nicola Brandt

783. Israel: Monetary and fiscal policy (June 2010) by Charlotte Moeser

782. Policy options for reducing poverty and raising employment rates in Israel (June 2010) by Philip Hemmings

781. Israeli education policy: How to move ahead in reform (June 2010) by Philip Hemmings 